\title{
Atlas and Zoogeography of Common Fishes in the Bering Sea and Northeastern Pacific
}

M. James Allen

Gary B. Smith

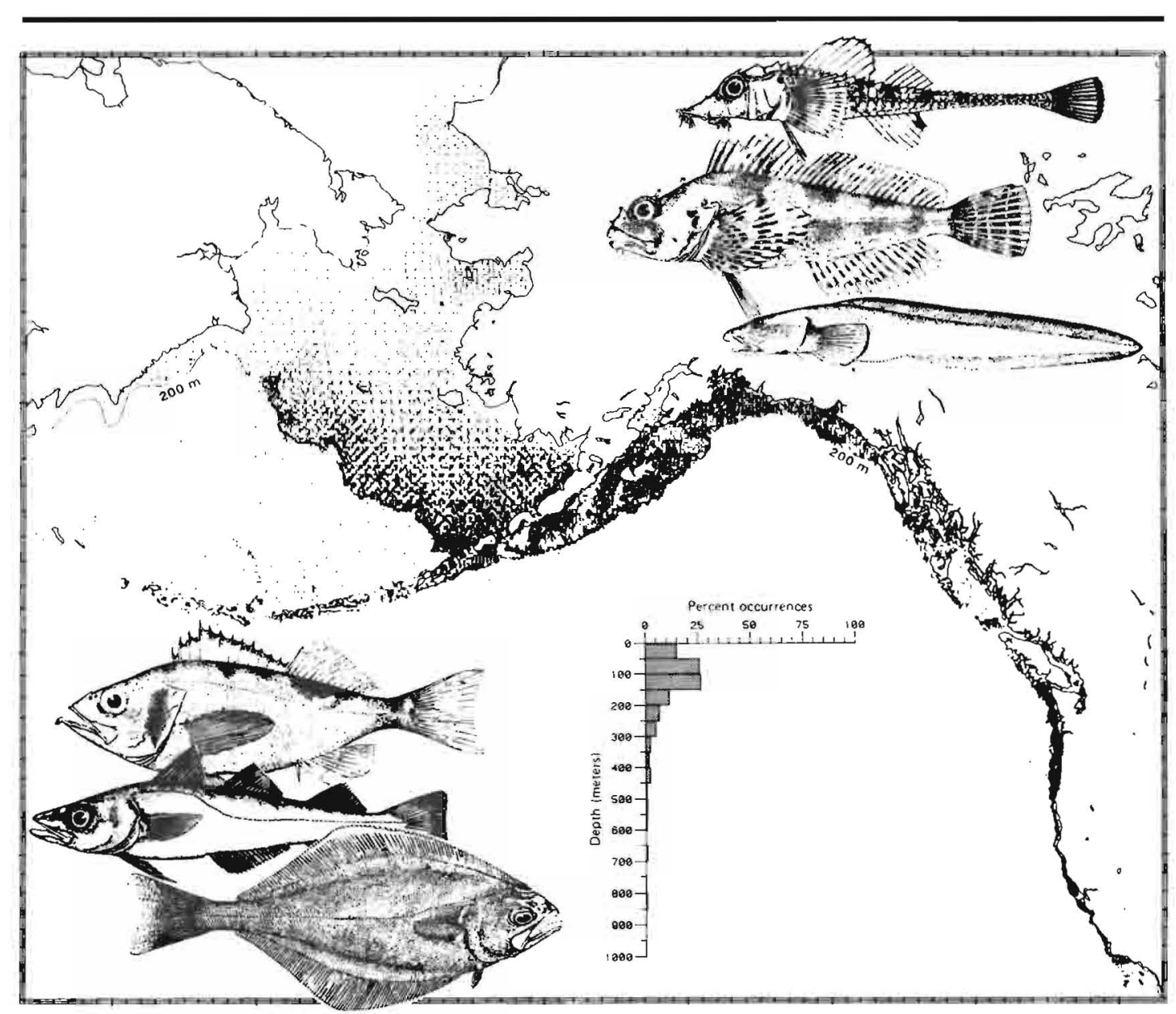
National Marine Fisheries Service 


\section{NOAA TECHNICAL REPORT NMFS}

The major responsibilities of the National Marine Fisheries Service (NMFS) are 10 monitor and assess the abundance and geographic distribution of fishery resources, to understand and predict fluctuations in the quantity and distribution of these resources. and to establish levels for their optimum use. NMFS is also charged with the development and implementation of policies for managing national fishing grounds, development and enforcement of domestic fisheries regulations, surveillance of foreign fishing off United States coastal waters, and the development and enforcement of international fishery agreements and policies. NMFS also assists the fishing industry through marketing service and economic analysis programs, and mortgage insurance and vessel construction subsidies. It collects, analyzes, and publishes statistics on various phases of the industry.

The NOAA Technical Repor NMFS series was established in 1983 to replace two subcategorics of the Technical Reports series: "Special Scientific Report-Fisheries" and "Circular." The series contains the following types of reports: Scientific investigations that document long-term continuing programs of NMFS; intensive scientific reports on studies of restricted scope; papers on applied fishery problems; technical reports of general interest intended to aid conservation and management; reports that review in considerable detail and at a high technical level certain broad areas of research; and technical papers originating in economics studies and from management investigations. Since this is a formal series, all submitted papers receive peer review and those accepted receive professional editing before publication.

Copies of NOAA Technical Reports NMFS are available free in limited numbers to governmental agencies, both Federal and State. They are also available in exchange for other scientific and technical publicasions in the marine sciences. Individual copies may be obtained from: U.S. Department of Commerce. National Technical Information Service, 5285 Port Royal Road, Springfield, VA 2216l. Although the contents have not been copyrighted and may be reprinted entirely, reference to source is appreciated.

13. Guidelines for reducing porpoise mortality in tuna purse seining, by James $M$ Coe, David B. Holts, and Richard W. Butler. September 1984, 16 p.

14. Synopsis of biological data on shornose sturgeon, Acipenser brevirostrum LeSueur 1818, by Michael J. Dadswell, Bruce D. Taubert, Thomas S. Squiers, Donald Marchette, and Jack Buckley. October 1984, $45 \mathrm{p}$

15. Chaetognatha of the Caribbean sea and adjacent areas, by Harding B. Michel October 1984, $33 \mathrm{p}$.

16. Proceedings of the Ninth and Tenth U.S. Japan Meetings on Aquaculture, by Carl J. Sindermann (editor). November 1984, $92 \mathrm{p}$

17. Identification and estimation of size from the beaks of 18 species of cephalopods from the Pacific Ocean, by Gary A. Wolff. November 1984, $50 \mathrm{p}$.

18. A temporal and spatial study of invertebrate communities associated with hardbotrom habitats in the South Atlantic Bight, by E. L. Wenner, P. Hinde, D. M. Knott, and R. F. Van Dolah. November 1984, 104 p.

19. Synopsis of biological data on spottail pinfish, Diplodus holbrooki (Pisces: Sparidae), by George H. Darcy. January 1985, $11 \mathrm{p}$.

20. Ichthyoplankton of the Continental Shelf near Kodiak Island, Alaska, by Arthur W. Kendall, Jr., and Jean R. Dunn. January 1985, 89 p.

21. Annotated bibliography on hypoxia and its effects on marine life, with emphasis on the Gulf of Mexico, by Maurice L. Renaud. February 1985, 9 p.

22. Congrid eels of the eastern Pacific and key to their Leptocephali, by Solomon N. Raju. February 1985, 19 p.

23. Synopsis of biological data on the pinfish, Lagodon rhomboides (Pisces:Sparidae), by George H. Darcy, February 1985, 32 p.

24. Temperature conditions in the cold pxol 1977-81: A comparison between southem New England and New York transects, by Steven K. Cook. February 1985, 22 p.

25. Parasitology and pathology of marine organisms of the world ocean, by William J. Hargis, Jr. (editor). March 1985, $135 \mathrm{p}$.

26. Synopsis of biological data on the sand perch. Diplectrum formosum (Pisces: Serranidae), by George H. Darcy. March 1985, 21 p.

27. Proceedings of the Eleventh U.S.-Japan Meeting on Aquaculture, Salmon Enhancement, Tokyo, Japan, October 19-20, 1982, by Carl J. Sindermann (editor). March 1985, $102 \mathrm{p}$.

28. Review of geographical stocks of tropical dolphins (Stenella spp. and Delphinus delphis) in the eastern Pacific, by William F. Perrin, Michael D. Scon, G. Jay Walker, and Virginia L. Cass. March 1985, 28 p.

29. Prevalence, intensity, longevity, and persistence of Anisakis sp. larvae and Lacistorhynchus ienuis metacestodes in San Francisco striped bass, by Mike Moser. Judy A. Sakanari, Carol A. Reilly, and Jeannette Whipple. April 1985, 4 p.

30. Synopsis of biological data on the pink shrimp, Pandalus borealis Kroyer, 1838 , by Sandra E. Shumway. Herbert C. Perkins, Daniel F. Schick, and Alden P. Stickney. May $1985,57 \mathrm{p}$.
31. Shark catches from selected fisheries off the U.S. east coast, by Emory D. Anderson. John G. Casey, John J. Hoey, and W. N. Witzell. July 1985, 22 p.

32. Nutrient Distributions for Georges Bank and adjacent waters in 1979, by A. F. J. Draxler, A. Matte, R. Waldhauer, and J. E. O'Reilly. July 1985, 34 p.

33. Marine flora and fauna of the Northeastern United States. Echinodermata: Echinoidea, by D. Keith Serafy and F. Julian Fell. September 1985, 27 p.

34. Additions to a revision of the shark genus Carcharhinus: Synonymy of Aprionodon and Hypoprion, and description of a new species of Carcharhinus (Carcharhinidae), by J. A. F. Garrick. November 1985, 26 p.

35. Synoptic review of the literature on the Southern oyster drill Thais haemastoma floridana, by Philip A. Butler. November 1985, 9 p.

36. An egg production method for estimating spawning biomass of pelagic fish: Application to the northern anchovy, Engraulis mordax, by Reuben Lasker (editor). December $1985,99 \mathrm{p}$.

37. A histopathologic evaluation of gross lesions excised from commercially important North Allantic marine fishes, by Roben A. Murchelano, Linda Despres-Patanjo. and John Ziskowski. March 1986, 14 p.

38. Fishery atlas of the northwestern Hawaiian Islands, by Richard N. Uchida and James H. Uchiyama (editors). September 1986, $142 p$

39. Survey of fish protective facilities at water withdrawal sites on the Snake and Columbia Rivers, by George A. Swan, Tommy G. Withrow, and Donn L. Park. April 1986, $34 \mathrm{p}$.

40. Potential impact of ocean thermal energy conversion (OTEC) on fisheries, by Edward P. Myers, Donald E. Hoss, Walter M. Matsumoto, David S. Peters, Michael P. Seki, Richard N. Uchida, John D. Ditmars, and Robert A. Paddock. June 1986, 33 p.

41. A stationary visual census technique for quantitatively assessing community structure of coral reef fishes, by James A. Bohnsack and Scott P. Bannerot. July 1986, 15 p.

42. Effects of temperature on the biology of the northern shrimp, Pandalus borealis, in the Gulf of Maine, by Spencer Apollonio, David K. Stevenson, and Earl E. Dunton, Jr. September 1986, 22 p.

43. Environment and resources of seamounts in the North Pacific, by Richard $N$. Uchida, Sigeiti Hayasi, and George W. Boehler (editors). September 1986, 105 p.

44. Synopsis of biological data on the porgies, Calamus arctifrons and $C$. proridens (Pisces: Sparidae), by George H. Darcy. September 1986, 19 p.

45. Meristic variation in Sebastes (Scorpaenidae), with an analysis of character ass $\propto$ ciation and bilateral pattem and their significance in species separation, by Lo-chai Chen September $1986,17 \mathrm{p}$

46. Distribution and relative abundance of pelagic nonsalmonid nekton off Oregon and Washington 1979-84, by Richard D. Brodeur and William G. Pearcy. December 1986. $85 \mathrm{p}$ 
NOAA Technical Report NMFS 66

\section{Atlas and Zoogeography of Common Fishes in the Bering Sea and Northeastern Pacific}

M. James Allen

Gary B. Smith

April 1988

U.S. DEPARTMENT OF COMMERCE

C. William Verity, Jr., Secretary

National Oceanic and Atmospheric Administration

William E. Evans, Under Secretary for Oceans and Atmosphere

National Marine Fisheries Service 
The National Marine Fisheries Service (NMFS) does not approve, recommend or endorse any proprietary product or proprietary material mentioned in this publication. No reference shall be made to NMFS, or to this publication furnished by NMFS, in any advertising or sales promotion which would indicate or imply that NMFS approves, recommends or endorses any proprietary product or proprietary material mentioned herein, or which has as its purpose an intent to cause directly or indirectly the advertised product to be used or purchased because of this NMFS publication. 


\section{CONTENTS}

Introduction 1

Methods

Data sources and characteristics $I$

Database retrievals and analyses 2

Survey coverage and limitations 3

Extensions of known ranges 3

Distributional classification schemes 3

Characteristics of Common Species 7

Class Chondrichthyes

Chimaeriformes

Chimaeridae: Shortnose chimaeras 10

Squaliformes

Squalidae: Dogfish sharks 11

Rajiformes

Torpedinidae: Electric rays 12

Rajidae: Skates 13

Class Osteichthyes

Clupeiformes

Clupeidae: Herrings 17

Salmoniformes

Bathylagidae: Deepsea smelts 19

Osmeridae: Smelts 20

Salmonidae: Salmonids 23

Stomiiformes

Chauliodontidae: Viperfishes 24

Gadiformes

Macrouridae: Grenadiers 25

Merlucciidae: Merlucciid hakes 27

Gadidae: Cods 28

Moridae: Morid cods 33

Batrachoidiformes

Batrachoididae: Toadfishes 34

Scorpaeniformes

Scorpaenidae: Scorpionfishes 35

Anoplopomatidae: Sablefishes 61

Hexagrammidae: Greenlings 62

Cyclopteridae: Lumpfishes and snailfishes 65

Psychrolutidae: Soft sculpins 70

Agonidae: Poachers 73

Hemitripteridae: Spinulated sculpins 79

Cottidae: Sculpins 80
Perciformes

Embiotocidae: Surfperches 97

Bathymasteridae: Ronquils 98

Zoarcidae: Eelpouts 100

Stichaeidae: Pricklebacks 108

Zaproridae: Prowfishes 112

Trichodontidae: Sandfishes 113

Ammodytidae: Sand lances 114

Pleuronectiformes

Paralichthyidae: Whiffs 115

Pleuronectidae: Righteye flounders 116

Extensions of Known Ranges 134

Zoogeographic and Life Zone Classification 135

Discussion 144

Conclusions 145

Acknowledgments $\quad 145$

Citations 146

Systematic Index 149 



\section{Atlas and Zoogeography of Common Fishes in the Bering Sea and Northeastern Pacific}

\author{
M. JAMES ALLEN ${ }^{1}$ \\ GARY B. SMITH ${ }^{2}$ \\ Northwest and Alaska Fisheries Center \\ National Marine Fisheries Service, NOAA \\ 7600 Sand Point Way NE \\ Seattle, Washington 98115
}

\begin{abstract}
The geographic and depth frequency distribution of 124 common demersal fish species in the northeastern Pacific were plotted from data on file at the Northwest and Alaska Fisheries Center (NWAFC), National Marine Fisheries Service. The data included catch records of fishes and invertebrates from 24,881 samples taken from the Chukchi Sea, throughout the Bering Sea, Aleutian Basin, Aleutian Archipelago, and the Gulf of Alaska, and from southeastern Alaska south to southern California. Samples were collected by a number of agencies and institutions over a 30-year period (1953-83), but were primarily from NWAFC demersal trawls. The distributions of all species with 100 or more occurrences in the data set were plotted by computer.

Distributions plotted from these data were then compared with geographic and depth-range limits given in the literature. These data provide new range extensions (geographic, depth, or both) for 114 species. Questionable extensions are noted, the depth ranges determined for $95 \%$ of occurrences, and depths of most frequent occurrence are recorded.

Ranges of the species were classified zoogeographically, according to life zone, and with regard to the depth zone of greatest occurrence. Because most species examined have broad geographic ranges, they do not provide the best information for testing the validity of proposed zoogeographic province boundaries. Because of the location of greatest sampling effort and methods used in sampling, most fishes examined were eastern boreal Pacific, sublittoral-bathyal (outer sheif) species.
\end{abstract}

\section{INTRODUCTION}

The coastal region of the northeastern Pacific and Bering Sea can be divided into a number of zoogeographic provinces, each of which contains a relatively distinctive fauna (Briggs 1974). Each zoogeographic region represents a particular set of environmental conditions, and includes species that have lived together during their recent evolutionary history. Zoogeographic studies of marine fishes are typically based on distributional records of the species from museum collections or from the literature. However, because of the relatively small numbers of records available from these sources, the geographic distribution of the fishes is sketchily defined and undue importance is often placed on records from the edges of the species' ranges. Because individuals taken at the extreme edge of a range may be strays or may represent a transiently established population in an atypically occupied region, zoogeographic patterns are often unclearly defined.

During the past 20 years a number of foreign and domestic agencies have conducted research surveys (mostly using bottom trawls) in the northeastern Pacific and Bering Sea to assess the status of fish stocks in these regions. Data on the species composition of about 25,000 samples are at present in computer files at the Northwest and Alaska Fisheries Center (NWAFC), National Marine Fisheries Service (NMFS), described by Mintel and Smith (1981). Because of recently developed computer-mapping techniques, the distribution of individual species occurring in these surveys can easily be plotted for the whole northeastern Pacific and Bering Sea. These distributional plots provide a better description of the overall distribution of each species within these regions than is generally available for most zoogeographic studies. This is because regions of rare occurrence near the edges of ranges can be distinguished from regions of common occurrence. The objectives of this study are to provide an atlas of the overall distribution pattern (including both depth and geographic distribution) of the most common fish species in the northeastern Pacific and Bering Sea, and to classify these species with regard to their distributional patterns (zoogeographic, life zone, and bathymetric).

\section{METHODS}

\section{Data sources and characteristics}

This study is based on information available in the computer database system developed at the NWAFC for storing and using fisheries survey information (Mintel and Smith 1981). The database includes results from approximately 32 years of resource survey investigations by the NMFS (and its predecessor agencies) in the Pacific Northwest and Alaska regions. Most of these data were collected in large-scale, bottom-trawl surveys conducted by the NWAFC's Resource Assessment and Conservation Engineering (RACE) Division. In addition, the database contains extensive collections of fisheries survey data from other sources, including the following: 1) surveys using other sampling methods, such as midwater trawls and fish traps; 2) published and unpublished cruise results from the International Pacific Halibut Commission, Alaska Department of Fish and Game, Far Seas Fisheries Research Laboratory (Shimizu, Japan), Fisheries Research Board of Canada, and Oregon Department of Fish and Wildlife; and 3) fisheries survey data from cooperative foreign research cruises with Japan, Poland, the

U.S.S.R., Canada, and Republic of Korea.
'Present address: MBC Applied Environmental Sciences, 947 Newhall St., Costa Mesa, CA 92627.

${ }^{2}$ Present address: Northwest Images, 3218 Franklin Ave. East, Seattle, WA 98102. 
The data from most of the resource surveys represented in the database (and particularly surveys conducted by the RACE Division) were collected by relatively standard procedures (see Dark et al. 1980; Gunderson and Sample 1980; Parks and Hughes 1981; and Smith and Bakkala 1982 for representative examples). Sampling stations were located within a study area in a prearranged pattern, usually a systematic grid. At each station a trawl net was towed, or a fish trap was set, for a standard duration. Fish and invertebrates recovered in the sample were identified to the lowest reliable taxonomic level, weighed, and counted. Taxonomic identifications of fishes have generally been made by fishery biologists using the best available field guides and keys, but also by specialists with particular expertise in fish systematics. The principal literature used to identify fishes in the various regions has been Wilimovsky (1958), Hitz (1981), Miller and Lea (1972), Hart (1973), and Eschmeyer and Herald (1983).

In surveys conducted by the RACE Division, all standard data were edited and filed with all previous results in the NWAFC's computer database at the end of each cruise leg.

\section{Database retrievals and analyses}

The data resources in the NWAFC system are organized into three geographic databases: Bering Sea and Aleutian Islands, Gulf of Alaska, and Pacific Coast (Mintel and Smith 1981). The database for each area has five primary files that include the basic survey data. Two of them, haul and catch files, were used for this study.
Haul file data describe the characteristics of each sampling site. At the time of this study, the haul file contained 24,881 records, distributed as follows: Bering Sea and Aleutian Islands 10,697; Gulf of Alaska 10,806; and Pacific Coast 3,378. Catch file data describe the catch information from each survey sample and include a 5-digit species code, weight, and number. There is one record per taxon and usually multiple catch records per haul. The catch file includes more than 330,000 records.

In this study, catch data for a particular fish species were first retrieved from each regional database, then associated with the corresponding haul data, and finally mapped and summarized statistically. The geographic distribution of a species was plotted using three computer programs: STATION; UNDER/PLOT; and MAP (Mintel and Smith 1981). Program STATION was used to select data from the haul file for plotting. Because some species occurred in numerous samples, it was necessary to control overplotting of stations by using program UNDER/PLOT to subdivide all maps into a grid of statistical blocks about the size of a plot symbol, $5^{\prime}$ latitude by $5^{\prime}$ longitude, and representing all occurrences of stations within a block by a single " +" character. Program MAP was then used to draw an actual map and include 200-m depth contours. The distribution of a species, or a set of stations, with respect to sampling depths was summarized using the FREQUENCIES procedure available in the SPSS statistical package (Nie et al. 1975). This method calculated the total number of occurrences in each 50-m interval of the depth range, e.g., 0-49 m, 50-99 m, $100-149 \mathrm{~m}$.

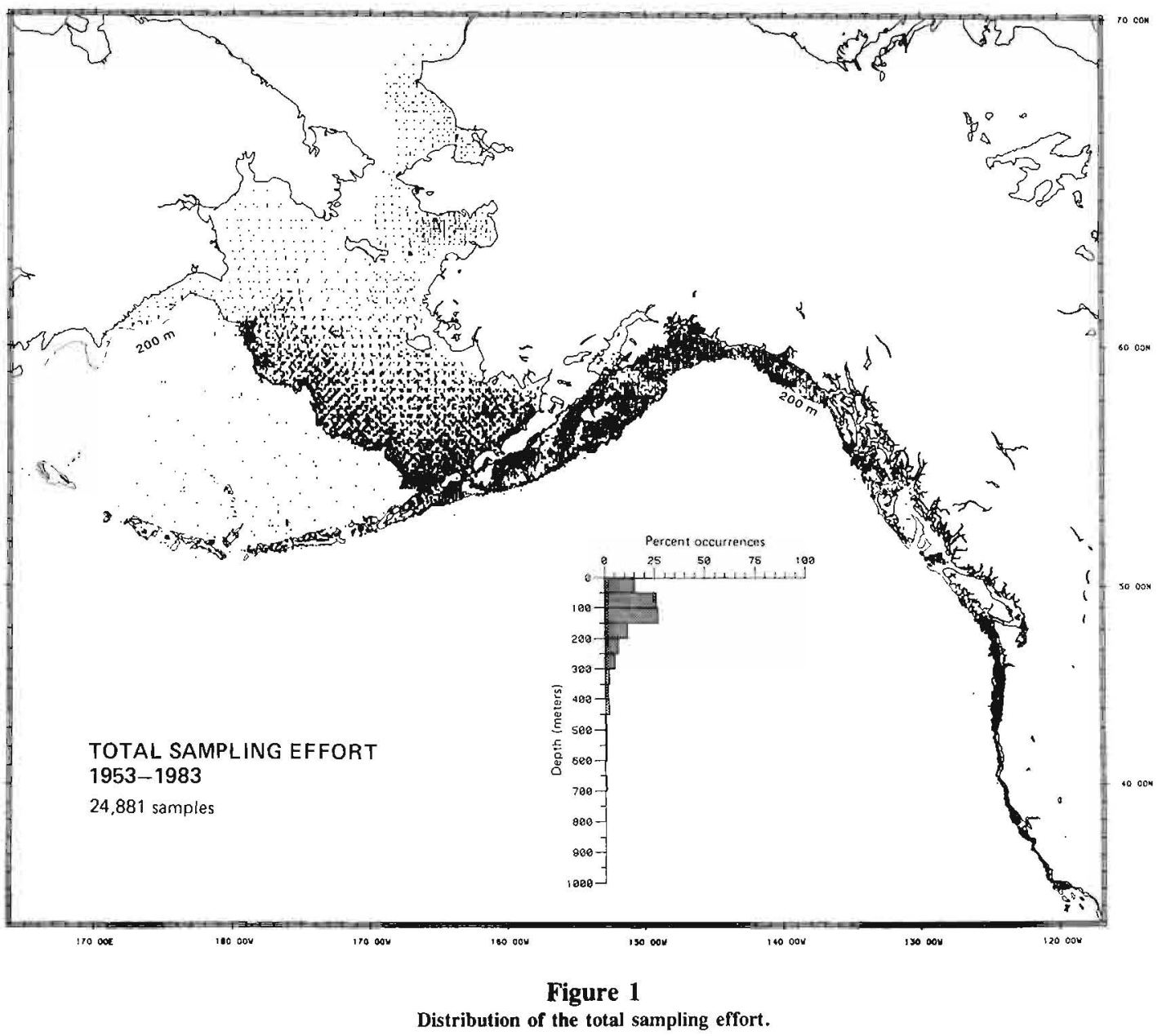




\section{Survey coverage and limitations}

The total sampling effort (i.e., 24,881 trawl and fish trap samples) represented in the database was distributed over an extensive geographic area (Fig. 1). Data were available for the continental shelf and slope of western North America and northeastern Asia from north of Cape Lisburne (lat. $68^{\circ} 53^{\prime} \mathrm{N}$ ) in the Chukchi Sea, south throughout the Bering Sea (including the continental shelf of northeast Siberia north of Cape Olyutorski, U.S.S.R.), the Aleutian Basin and eastward from the Commander Islands along the Aleutian Islands, and along the U.S. Pacific coast from the Gulf of Alaska to San Clemente Island, California (ca. lat. $33^{\circ} \mathrm{N}$, long. $\left.118^{\circ} 30^{\prime} \mathrm{W}\right)$. Geographic distribution of the data was not even; $86.4 \%$ of the haul data had been collected off Alaska and only $13.6 \%$ were taken off California, Oregon, Washington, and western Canada.

Similarly, although the sampling coverage extended to deeper than $1,200 \mathrm{~m}$, it was biased toward continental shelf depths because most of the surveys were conducted to assess continental shelf resources important to commercial fisheries. A total of $77.9 \%$ of the 24,881 survey samples had been taken at depths shallower than $200 \mathrm{~m}$, mostly over continental shelf areas (see Figure 1, Table 1). This intensive sampling effort on the shelf was a potential source of bias and distortion in the summaries of vertical distribution patterns. In addition, few samples were taken at depths less than $30 \mathrm{~m}$; hence, the importance of some species in the intertidal and shallow subtidal zones may not be apparent.

The database contained some misidentifications and errors. Sometimes these appeared in maps as isolated points representing either incidental misidentifications or errors in data codes. In other cases,

\section{Table 1}

Frequency distribution of the total sampling effort vs. depth for data collected from the Chukchi Sea and Bering Sea to southern California.

\begin{tabular}{cccc}
\hline $\begin{array}{c}\text { Depth interval } \\
(\mathrm{m})\end{array}$ & Frequency' & $\begin{array}{c}\text { Percent } \\
\text { frequency }\end{array}$ & $\begin{array}{c}\text { Cumulative } \\
\text { percent }\end{array}$ \\
\hline $0-49$ & 3,823 & 15.4 & 15.4 \\
$50-99$ & 5,997 & 24.1 & 39.5 \\
$100-149$ & 6,532 & 26.3 & 65.8 \\
$150-199$ & 3,030 & 12.2 & 78.0 \\
$200-249$ & 1,678 & 6.7 & 84.7 \\
$250-299$ & 1,260 & 5.1 & 89.8 \\
$300-349$ & 604 & 2.4 & 92.2 \\
$350-399$ & 373 & 1.5 & 93.7 \\
$400-449$ & 489 & 2.0 & 95.7 \\
$450-499$ & 167 & 0.7 & 96.4 \\
$500-549$ & 173 & 0.7 & 97.1 \\
$550-599$ & 134 & 0.5 & 97.6 \\
$600-649$ & 77 & 0.3 & 97.9 \\
$650-699$ & 160 & 0.6 & 98.5 \\
$700-749$ & 70 & 0.3 & 98.8 \\
$750-799$ & 63 & 0.3 & 99.1 \\
$800-849$ & 146 & 0.6 & 99.7 \\
$850-899$ & 32 & 0.1 & 99.8 \\
$900-949$ & 12 & $<0.1$ & 99.8 \\
$950-999$ & 13 & $<0.1$ & 99.8 \\
$1,000-1,049$ & 13 & $<0.1$ & 99.9 \\
$1,050-1,099$ & 1 & $<0.1$ & 99.9 \\
$1,100-1,149$ & 0 & 0.0 & 99.9 \\
$1,150-1,199$ & 0 & 0.0 & 99.9 \\
$\geqslant 1,200$ & 34 & 0.1 & 100.0 \\
Total & -139 & 100.0 & 100.0 \\
\hline Number of trawl and fish trap samples. & & \\
\hline & & & \\
\hline
\end{tabular}

several fish species were probabiy consistently misidentified over large areas for several years. These problems are discussed in the text describing the distribution of each species.

Most of the survey data were collected using commercial fishing gear with large mesh sizes. Principal sampling gears included the 400-mesh Eastern trawl, 81/112 Eastern trawl, 61-foot shrimp trawl, Nor'Eastern otter trawl, and similar nets (Wathne 1977; Gunderson and Sample 1980) These were generally inefficient for capturing small fishes.

Descriptions of depth distributions are based on reported "sampling depth" information. The sampling depth recorded was generally the maximum depth at which a trawl net was towed to collect a sample. However, since open mouth nets were used, all of the trawl samples must be considered to have been oblique net tows that may have collected organisms at any depth along the tow path. As a result, some fishes (pelagic fishes, especially) may have been recorded at greater depths than they actually occurred. In addition, the efficiencies of the various sampling gears probably varied with depth.

The geographic distribution pattern of each species included in this study is based on the presence or absence of the species in a $5 \times 5$ minute block and, hence, does not show either frequency of occurrence in that block or abundance.

\section{Extensions of known ranges}

The geographic and depth ranges found in the survey data were then compared with ranges found in the literature for each species. Major references for this information included Andriyashev (1954), Wilimovsky (1964), Miller and Lea (1972), Quast and Hall (1972), Fedorov (1973a), Hart (1973), Howe (1981), and Eschmeyer and Herald (1983). Other sources were cited if they provided range limits not given in the general references or more specific locations. No attempt was made to track down original citations for range limits found in the more general literature. Some of these are cited in Andriyashev (1954), Quast and Hall (1972), and Hart (1973).

Extensions of known ranges were then evaluated for potential validity. Questionable extensions were annotated as follows: 1) additional specific information may occur in the literature, 2) the extension may represent a misidentification, 3) a maximum depth extension may not be representative, or 4 ) the extension is anomalous in occurring far outside the known range of the species.

\section{Distributional classification schemes}

\section{Zoogeographic classification scheme}

Zoogeographic classification schemes group geographic areas with different faunas into zones, regions, and provinces. These faunal groups generally occur in different latitudinal (or climatic) zones and on different continents (or other definable geographic areas). Ekman (1953), Hedgpeth (1957b), and Briggs (1974) summarized the literature on zoogeographic patterns of coastal marine fishes and invertebrates and defined coastal zoogeographic zones for the world. Briggs (1974) divided major latitudinal climatic zones into regions (usually on different continents) and further divided these into provinces, each of which include $10 \%$ or more endemic species. Hubbs (1974) and Peden and Wilson (1976) have criticized this study with regard to the location of provincial boundaries in the northeastern Pacific. The zoogeographic patterns of fishes in the North Pacific and Bering Sea have been described by Andriyashev (1939), 


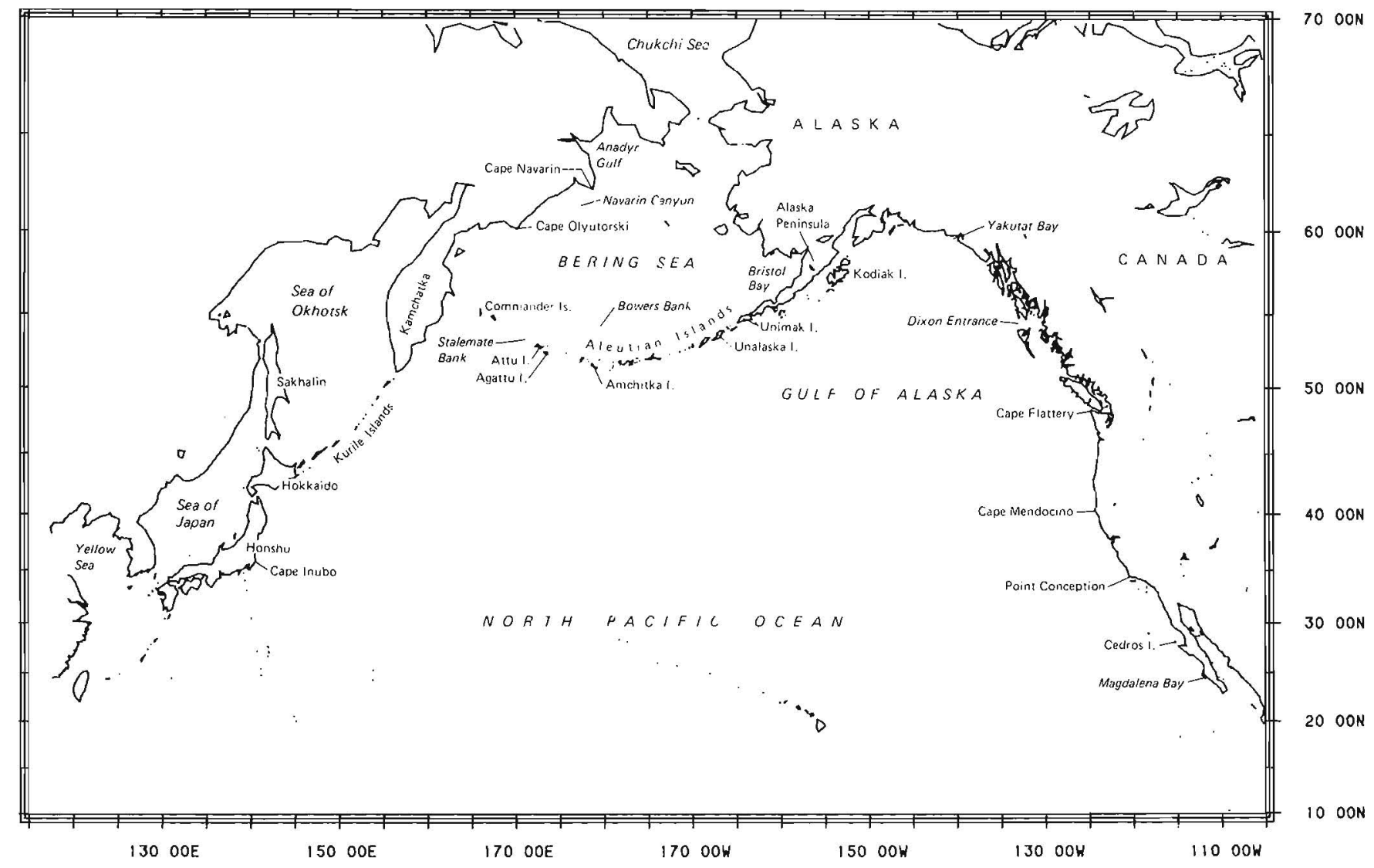

Figure 2

Important geographic locations mentioned in text.

Shmidt (1950), Quast (1968), and Horn and Allen (1978). McGowan (1971) defined zoogeographic zones in the oceanic North Pacific based primarily on the distribution of zooplankton species. It should be noted that abyssal zoogeographic regions are different from those found in surface waters (Menzies et al. 1973).

The zoogeographic classification scheme used in this study for describing the geographic ranges of fish species is based primarily on the schemes proposed by McGowan (1971) and Briggs (1974) (Figure 2, 3; Table 2). Regions and provinces pertinent to distributions of common fishes in the Bering Sea include the following: 1) Arctic Region; 2) Eastern Boreal Pacific Region (including the Aleutian and Oregonian Provinces); 3) Western Boreal Pacific Region (including the Kurile, Okhotsk, and Oriental Provinces); 4) Oceanic Boreal Pacific Region (including the Subarctic Province and Transition Zone); 5) California Region (including the San Diego and Cortez Provinces); 6) Japan Region; 7) Western Boreal Atlantic Region; 8) Eastern Boreal Atlantic Region; 9) Carolina Region; and 10) Mediterranean-Atlantic Region (Lusitania Province only).

\section{Zoogeographic classification of species geographic ranges}

The geographic range of each species usually extends over more than one zoogeographic province. Hence, the range of each species can be described in terms of the zoogeographic provinces through which it extends. Where one or two provinces are spanned by the range, the terms given here will be those of the provinces. Terms that require further definition include the following: amphiboreal-occurring in both Atlantic and Pacific boreal regions,

circumboreal-occurring throughout the coastal boreal regions of an ocean. In the North Atlantic this includes both the Western Boreal Atlantic and Eastern Boreal Atlantic Regions. In the North Pacific this includes Oriental, Kurile, Okhotsk, Aleutian, and Oregonian Provinces.

northeastern boreal Pacific-includes Kurile, Okhotsk, Aleutian, and Oregonian Provinces, but not the Oriental Province.

northwestern boreal Pacific-includes Oriental, Kurile, Okhotsk, and Aleutian Provinces, but not the Oregonian Province.

northern boreal Pacific-includes Okhotsk, Kurile, and Aleutian Provinces.

eastern boreal Pacific-includes Aleutian and Oregonian Provinces.

western boreal Pacific-includes Oriental, Kurile, and Okhotsk Provinces.

oceanic boreal Pacific-includes the Subarctic Province and Transition Zone.

temperate-includes boreal (cold-temperate) and warm-temperate provinces.

antitropical temperate-includes all temperate regions in both Northern and Southern Hemispheres.

temperate North Pacific-includes all temperate regions in the North Pacific.

eastern temperate Pacific-includes Aleutian, Oregonian, San Diegan, and Cortez Provinces. 


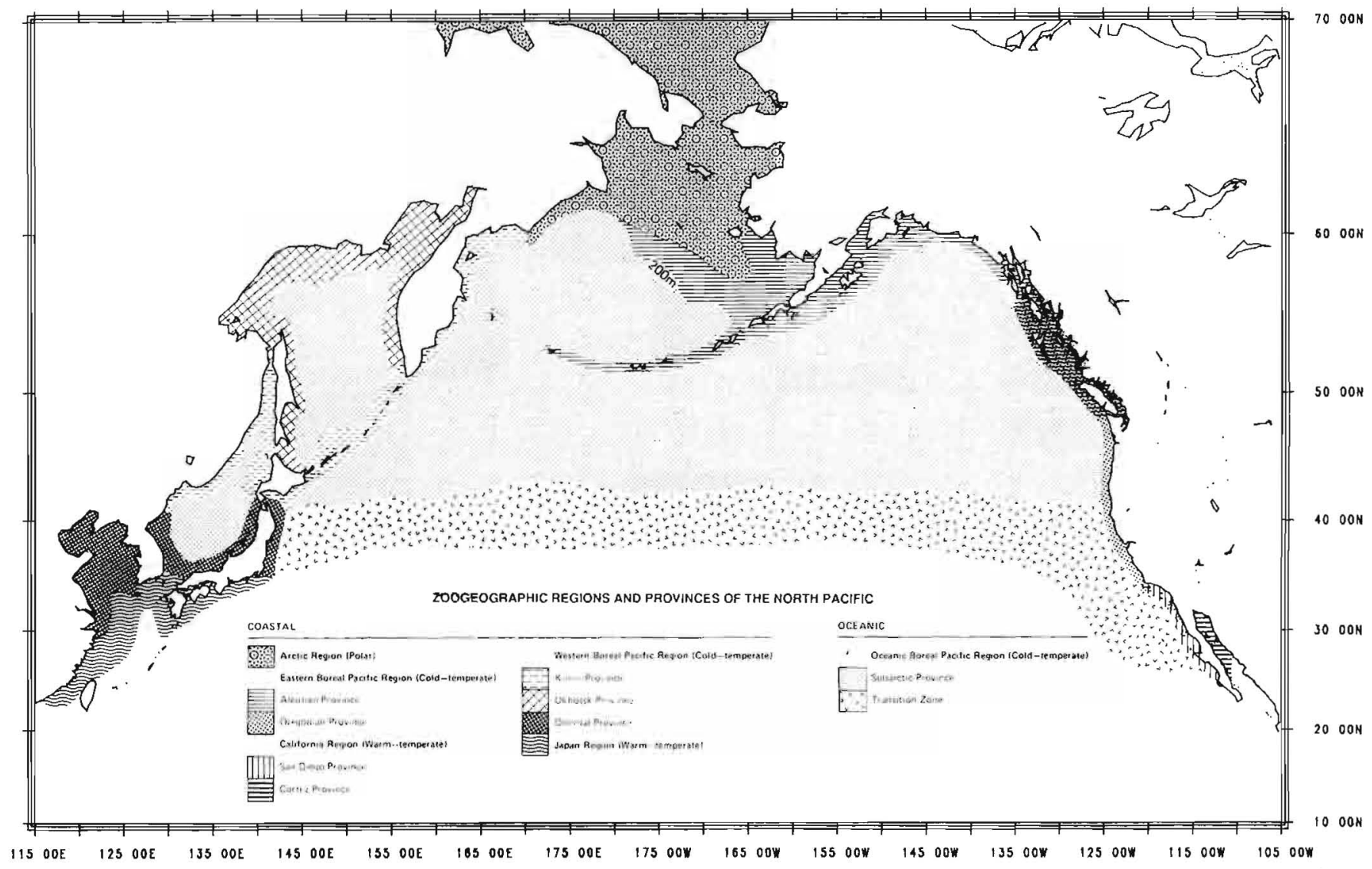

Figure 3

Zoogeographic provinces of the North Pacific.

Three geographic regions were considered "gray areas" in terms of classification. These include the Bering Sea from Nunivak Island and Cape Olyutorski to the Bering Strait; the coast from Sitka, Alaska, to Puget Sound, Washington; and the coast from Point Conception, California, to Cedros Island, Baja California. Each of these regions can be classed as either of two provinces recognized by Briggs (1974): Arctic or Aleutian for the Bering Sea, Aleutian or Oregonian for the eastern Gulf of Alaska, and Oregonian (Montereyan) or San Diegan for southern California-Baja California. If the range of a species extends from the north into one of the regions (but no further south), the region was included with the northern classification and the reverse if the species range was to the south. For instance, an Arctic species extending into the Bering Sea was considered to be Arctic and an Aleutian species extending to the Bering Strait was considered to be Aleutian even though both occurred in the northern Bering Sea. Species extending into the Chukchi Sea were considered Arctic although they may not extend further north.

\section{Life zone classification scheme}

Life zone classification schemes divide lifestyle regions (pelagic or benthic) into depth zones with different faunas. Other divisions of habitat (such as rocky bottom, soft-bottom, or kelp bed) are not considered in these schemes. Because many physical parameters (such as light intensity, pressure, and temperature) vary directly or indirectly with depth, organisms living in one zone are often quite different from those living in contiguous zones.

The most widely-used life zone classification scheme is that of Hedgpeth (1957a). This classification scheme divides the marine environment into two lifestyle regions: pelagic and benthic. The upper pelagic environment is divided into a Neritic Region above the shelf $(0-200 \mathrm{~m})$ and an Oceanic Region above the slope and basins. This latter region is divided into an Epipelagic Zone (0-100 $\mathrm{m})$, a Mesopelagic Zone (100-1000 m), and a Bathypelagic Zone $(1000-4000 \mathrm{~m})$. The upper benthic environment is divided into an Intertidal Zone, a Sublittoral Zone (0-200 m), and a Bathyal Zone (200-4000 m). In addition, deep ocean (Abyssal, Abyssopelagic, and Hadal) and estuarine zones are included.

Hedgpeth (1957a) suggested that the shelf could be divided into Inner and Outer Sublittoral Zones, the former extending from 0 to $100 \mathrm{~m}$ and the latter from 100 to $200 \mathrm{~m}$. Allen (1982) described three major zones for demersal fishes on the southern California shelf. These include an Inner Shelf Zone from 0 to $20 \mathrm{~m}$, and Outer Shelf Zone from 20 to $80 \mathrm{~m}$, and an Upper Slope Zone from 80 to $170 \mathrm{~m}$ (the shelf break is at $80 \mathrm{~m}$ ). In the Bering Sea (the broadest 
Table 2

Geographic limits of zoogeographic provinces of the Arctic-temperate Northern Hemisphere pertinent to distributions of common fishes in the Bering Sea and Northeastern Pacific (based primarily on McGowan 1971; Briggs 1974).

\begin{tabular}{|c|c|c|}
\hline \multirow{2}{*}{$\begin{array}{l}\text { Zoogeographic regions } \\
\text { and provinces }\end{array}$} & \multicolumn{2}{|c|}{ Geographic limits } \\
\hline & Northern & Southern \\
\hline \multicolumn{3}{|l|}{ Arctic Ocean } \\
\hline Arctic Region & North Pole & $\begin{array}{l}\text { Above Atlantic: Strait of Belle Isle, Labrador; northern Iceland; } \\
\text { Murmansk coast, USSR. Includes Greenland and Spitsbergen. } \\
\text { Bering Sea: Cape Olyutorski, USSR; and Nunivak Island, } \\
\text { Alaska }\end{array}$ \\
\hline \multicolumn{3}{|l|}{ Temperate North Pacific } \\
\hline \multicolumn{3}{|l|}{ Boreal (cold-temperate) } \\
\hline \multicolumn{3}{|l|}{ Eastern Pacific Region } \\
\hline Aleutian Province & Nunivak Island; Aleutian Islands & $\begin{array}{l}\text { Uncertain }^{3} \text {. Sitka, Alaska; Dixon Entrance (Alaska-British } \\
\text { Columbia border); or Cape Flattery, Washington }\end{array}$ \\
\hline Oregonian Province & $\begin{array}{l}\text { Uncertain }{ }^{\text {a }} \text { Sitka, Alaska; Dixon Entrance (Alaska-British } \\
\text { Columbia border); or Cape Flattery, Washington }\end{array}$ & $\begin{array}{l}\text { Point Conception, California; discontinuously in upwelling } \\
\text { areas of northern Baja California }{ }^{b}\end{array}$ \\
\hline \multicolumn{3}{|l|}{ Western Boreal Pacific Region } \\
\hline Kurile Province & $\begin{array}{l}\text { Cape Olyutorski, USSR (western Bering Sea); includes eastern } \\
\text { Kamchatka, USSR }\end{array}$ & $\begin{array}{l}\text { Peter the Great Bay, USSR (western Sea of Japan); includes } \\
\text { Kurile Islands, Hokkaido, Japan, and western Sea of Japan }\end{array}$ \\
\hline Okhotsk Province & Northern Sea of Okhotsk; southern Kamchatka, USSR & Northem Hokkaido, Japan (includes all of Sea of Okhotsk) \\
\hline Oriental Province & Northern Honshu, Japan & $\begin{array}{l}\text { Yellow Sea, China; Cape Inubo, eastern Honshu, Japan (in } \\
\text { cludes southern Sea of Japan but does not include southern } \\
\text { South Korea or the south coast of Honshu) }\end{array}$ \\
\hline \multicolumn{3}{|l|}{ Oceanic Boreal Pacific } \\
\hline Subarctic Province & Sea of Okhotsk; Aleutian Basin; Gulf of Alaska & Lat. $43^{\circ} \mathrm{N}$; Sea of Japan \\
\hline Transition Zone & Lat. $43^{\circ} \mathrm{N}$ & $\begin{array}{l}\text { Lat. } 37^{\circ} \mathrm{N} \text { (midocean); east-central Honshu, Japan; southern } \\
\text { Baja California Sur }\end{array}$ \\
\hline \multicolumn{3}{|l|}{ Warm-temperate } \\
\hline \multicolumn{3}{|l|}{ California Region } \\
\hline San Diego Province & Point Conception, California & Magdalena Bay, Baja California Sur, Mexico \\
\hline Cortez Province ${ }^{c}$ & Northern Gulf of California & La Paz, Baja California Sur; Topolobampo, Sinaloa, Mexico \\
\hline Japan Region & Cape Inubo, Honshu, Japan & $\begin{array}{l}\text { Formosa Strait, China (including the south coast of Honshu } \\
\text { and southern South Korea) }\end{array}$ \\
\hline \multicolumn{3}{|l|}{ Temperate North Atlantic } \\
\hline \multicolumn{3}{|l|}{ Boreal (cold-temperate) } \\
\hline Western Boreal Allantic Region & Strait of Belle Isle, Labrador & Cape Hatteras, North Carolina \\
\hline Eastem Boreal Allantic Region & Murmansk coast, USSR & Western English Channel (includes southern Iceland) \\
\hline \multicolumn{3}{|l|}{ Warm-temperate } \\
\hline Carolina Region & Cape Hatteras, North Carolina & Cape Rojo, Mexico (does not include southern Florida) \\
\hline \multicolumn{3}{|l|}{ Mediterranean-Atlantic Region } \\
\hline Lusitania Province & English Channel & Cape Verde, Senegal (includes Mediterranean Sea) \\
\hline
\end{tabular}

shelf in the region we studied) there are three faunistically-important hydrographic domains: 1) Inner Shelf $(0-50 \mathrm{~m}) ; 2)$ Middle Shelf (50-100 m); and 3) Outer Shelf (100-150 m; Kaimmer et al. 1976; Kinder and Schumacher 1981; Smith and Bakkala 1982). The shelf break occurs at $170 \mathrm{~m}$.

At present there is no consensus on the number and location of subdivisions of the Bathyal Zone (Menzies et al. 1973). Fedorov (1973a), based upon Bering Sea fishes, divided the bathyal environment into two zones: Mesobenthal $(200-500 \mathrm{~m})$ and Bathybenthal (500-2500 m). In this scheme the Abyssal (Abyssobenthal) Zone begins at $2500 \mathrm{~m}$ rather than at $4000 \mathrm{~m}$, as proposed by Hedgpeth (1957a).

Based on the above information, the following life zone classification scheme was used in this study (Fig. 4): 1) Peripheral environ-
ments-Fluvial (riverine), Estuarine, and Intertidal Zones; 2) Pelagic environments-Neritic (0-200 m) and Oceanic (Epipelagic, 0-200 m; Mesopelagic, 200-1000 m; Bathypelagic, $1000-4000$ m) Zones; and 3) Benthic environments-Sublittoral (Inner Shelf, 0-50 m; Middle Shelf, 50-100 m; Outer Shelf, 100-200 m) and Bathyal (Mesobenthal, 200-500 m; Bathybenthal, 500-2500 m). The depth range of the Epipelagic Zone was arbitrarily extended to $200 \mathrm{~m}$ to make it equivalent to the depth range of the Neritic Zone. It should be noted that the Inner Shelf Zone may actually end at depths shallower than $50 \mathrm{~m}$ in some parts of the study area.

The species were classified as pelagic or demersal based upon their use of the benthic environment. Pelagic species are regarded here as species which do not use the benthic marine environment during foraging or for refuge (although they may deposit untended 


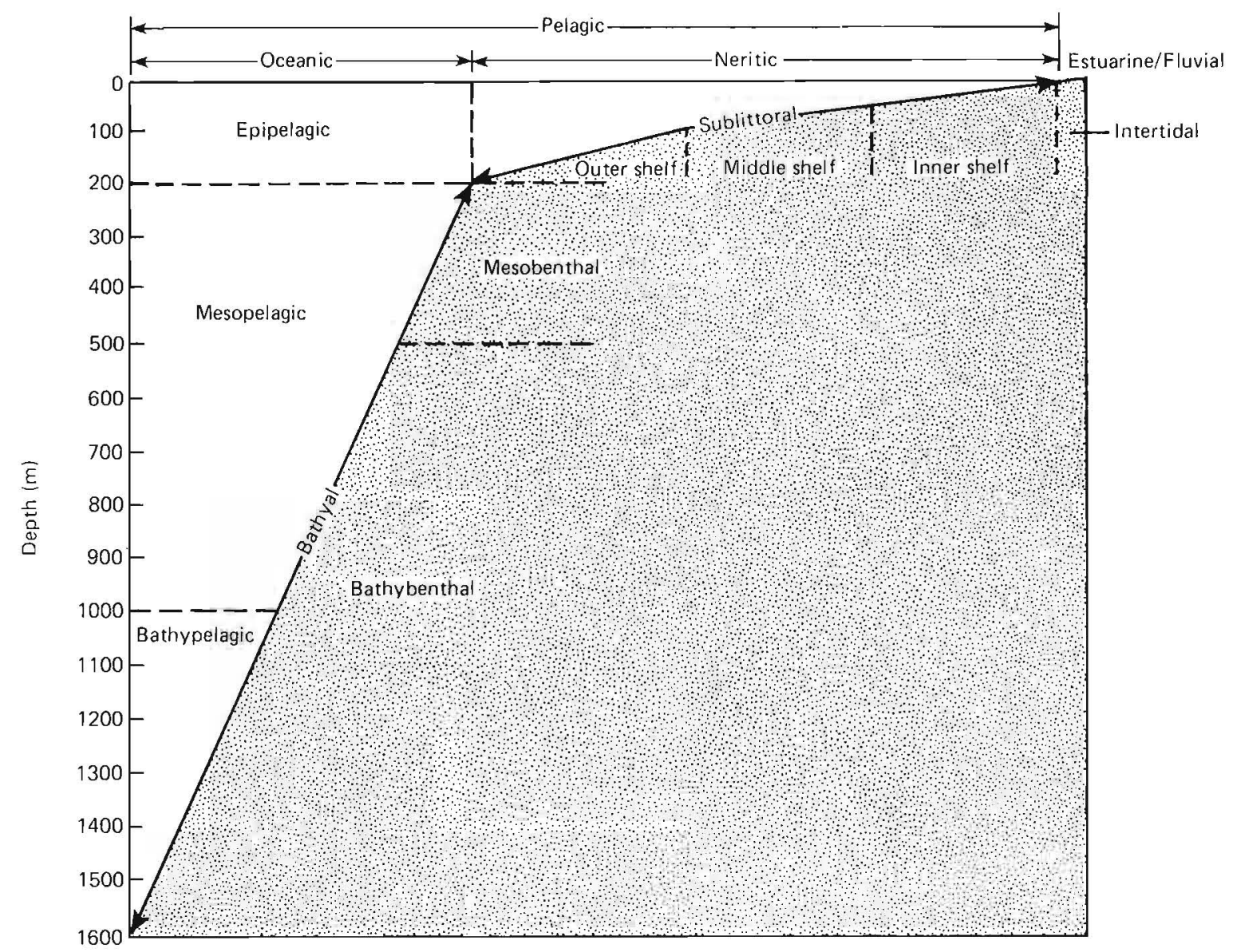

Figure 4

Coastal marine life zones.

demersal eggs or be captured near the bottom by demersal trawls). Demersal species are considered here to be species that use the benthic marine environment during foraging, for refuge, or for nest sites. Some of these species may spend a considerable amount of their time in the water column while others stay on or near the bottom. Some pelagic or demersal species could have been placed in the opposite category given that the categories were defined differently.

The species were assigned to life zone categories based on the range of life zones that include about $95 \%$ of the occurrences of each species. Fluvial, estuarine, intertidal, and epipelagic zones were included in the category name if these are important adult or juvenile habitats or spawning areas. The presence of pelagic juveniles was not considered when assigning species to categories. In addition to the range descriptor of the life zone occupied by a species, the life zone of the modal depth of occurrence was also included.

\section{CHARACTERISTICS OF COMMON SPECIES}

A total of 124 fish species (including three species complexes), representing 31 families, were found in 100 or more survey samples (Table 3). Families represented by the largest number of species were: Scorpaenidae 26; Pleuronectidae 18; Cottidae 17; Zoarcidae 8; Agonidae 6; Gadidae 5; Cyclopteridae 5; Rajidae 4; and Stichaeidae 4 . Sixteen families were represented by only one species.

In general, the species composition of the catch data showed the effects of the extensive sampling effort that had been conducted off Alaska. Nearly all of the most common species were northern, coldwater fishes (Table 4). Species that showed the highest frequency of occurrence among the 24,881 survey samples analyzed were the following: walleye pollock, Theragra chalcogramma (occurring in $59.9 \%$ of the samples); arrowtooth flounder, Atheresthes stomias (52.3\%); flathead sole, Hippoglossoides elassodon (50.9\%); Pacific cod, Gadus macrocephalus (49.8\%); Pacific halibut, Hippoglossus stenolepis $(39.1 \%)$; and rock sole, Pleuronectes bilineatus (35.0\%). 
Table 3

List of fish species collected from the Chukchi Sea to southern California that were found in 100 or more samples. ${ }^{1}$

\begin{tabular}{|c|c|c|c|}
\hline Species & Common name & Species & Common name \\
\hline Class Chondrichthyes & & S. proniger & Redstripe rockfish \\
\hline Order Chimaeriformes & & S. ruberrimus & Yelloweye rockfish \\
\hline Chimaeridae & & S. rubrivinctus & Flag rockfish \\
\hline Hydrolagus colliei & Sponted ratfish & S. saxicola & Stripetail rockfish \\
\hline Order Squaliformes & & S. variegatus & Harlequin rockfish \\
\hline Squalidae & & S. zacentrus & Sharpchin rockfish \\
\hline Squalus acanthias & Spiny dogfish & Sebastolobus aloscanus & Shortspine thornyhead \\
\hline Order Rajiformes & & Anoplopomatidae & \\
\hline Torpedinidae & & Anoplopoma fimbria & Sablefish \\
\hline Torpedo californica & Pacific electric ray & Hexagrammidae & \\
\hline Rajidae & & Hexagrammos stelleri & Whitespotted greenling \\
\hline Bathyraja interrupta & Bering skate & Ophiodon elongatus & Lingcod \\
\hline Raja binoculata & Big skate & Pleurogrammus monopterygius & Atka mackerel \\
\hline R. rhina & Longnose skate & Cyclopteridae & \\
\hline R. stellulata comple ${ }^{2}$ & "Starry skate" & Aptocyclus ventricosus & Smooth lumpsucker \\
\hline Class Osteichthyes & & Careproctus melanurus complex ${ }^{7}$ & "Blacktail snailfish"" \\
\hline Order Clupeiformes & & Careproctus rastrinus complex ${ }^{8}$ & "Pink snailfish", \\
\hline Clupeidae & & Eumicrotremus orbis & Pacific spiny lumpsucker \\
\hline Alosa sapidissima & American shad & Liparis gibbus & Dusky snailfishs ${ }^{5}$ \\
\hline Clupea pallasii & Pacific herring & Psychrolutidae & \\
\hline Order Salmoniformes & & Dasycontus setiger & Spinyhead sculpin \\
\hline Bathylagidae & & Malacocotıus kincaidi & Blackfin sculpin \\
\hline Leuroglossus schmidit ${ }^{3}$ & Northern smoothtongue ${ }^{4}$ & M. zonurus & Darkfin sculpin 9 \\
\hline Osmeridae & & Agonidae & \\
\hline Mallorus villosus & Capelin & Aspidophoroides bartoni & Aleutian alligatorfish \\
\hline Osmerus mordax & Rainbow smelt & Bathyagonus nigripinnis & Blackfin poacher \\
\hline Thaleichthys pacificus & Eulachon & Occella dodecaedron & Bering poacher \\
\hline Salmonidae & & o. verrucosa & Warty poacher \\
\hline Oncorhynchus tshawytscha & Chinook salmon & Podothecus acipenserinus ${ }^{10}$ & Sturgeon poacher \\
\hline Order Stomiiformes & & Sarritor frenatus & Sawback poacher \\
\hline Chauliodontidae & & Hemitripteridae ${ }^{11}$ & \\
\hline Chauliodus macouni & Pacific viperfish & Hemitripterus bolini & Bigmouth sculpin \\
\hline Order Gadiformes & & Cottidae & \\
\hline Macrouridae & & Enophrys diceraus & Antlered sculpin \\
\hline Albatrossia pectoralis & Giant grenadier $^{5}$ & Gymnocanthus galeatus & Armorhead sculpin \\
\hline Coryphaenoides cinereus & Popeye grenadier ${ }^{6}$ & G. pistilliger & Threaded sculpin ${ }^{5}$ \\
\hline Merlucciidae & & G. iricuspis & Arctic staghom sculpin \\
\hline Merluccius productus & Pacific hake & Hemilepidotus hemilepidotus & Red Irish lord \\
\hline Gadidae & & H. jordani & Yellow Irish lord \\
\hline Boreogadus saida & Arctic cod & H. papilio ${ }^{12}$ & Butterfly sculpin \\
\hline Eleginus gracilis & Saffron cod & Icelinus filamentosus & Threadfin sculpin \\
\hline Gadus macrocephalus & Pacific cod & Icelus canaliculatus & Porehead sculpin ${ }^{13}$ \\
\hline Microgadus proximus & Pacific tomcod & 1. spiniger & Thorny sculpin \\
\hline Theragra chalcogramma & Walleye pollock & Myoxocephalus jaok & Plain sculpin \\
\hline Moridae & & M. polyacanthocephalus & Great sculpin \\
\hline Antimora microlepis & Pacific flatnose ${ }^{5}$ & $M$. verrucosus & Warty sculpin \\
\hline Order Batrachoidiformes & & Triglops forficata & Scissortail sculpin \\
\hline Batrachoididae & & T. macellus & Roughspine sculpin \\
\hline Porichthys notatus & Plainfin midshipman & T. pingeli & Ribbed sculpin \\
\hline Order Scorpaeniformes & & T. scepticus & Spectacled sculpin \\
\hline Scorpaenidae & & Order Perciformes & \\
\hline Sebastes aleutianus & Rougheye rockfish & Embiotocidae & \\
\hline S. alutus & Pacific ocean perch & Zalembius rosaceus & Pink seaperch \\
\hline S. aurora & Aurora rockfish & Bathymasteridae & \\
\hline S. babcocki & Redbanded rockfish & Bathymaster signalus & Searcher \\
\hline S. borealis & Shortraker rockfish & Ronquilus jordani & Northern ronquil \\
\hline S. brevispinis & Silvergray rockfish & Zoarcidae & \\
\hline S. ciliatus & Dusky rockfish & Bothrocara brunneum & Twoline eelpour ${ }^{5}$ \\
\hline S. crameri & Darkblotched rockfish & Lycodes brevipes & Shortfin eelpout \\
\hline S. diploproa & Splitnose rockfish & L. concolor ${ }^{14}$ & Ebony eelpout ${ }^{13}$ \\
\hline S. elongatus & Greenstriped rockfish & L. cortezianus & Bigfin eelpout \\
\hline S. entomelas & Widow rockfish & L. diapterus & Black eelpout \\
\hline S. flavidus & Yellowtail rockfish & L. palearis & Wattled eelpout \\
\hline S. goodei & Chilipepper & $L$, raridens & Marbled eelpout ${ }^{9}$ \\
\hline S. helvomaculatus & Rosethorn rockfish & L. tumeri & Polar eelpout \\
\hline S. jordani & Shortbelly rockfish & Stichaeidae & \\
\hline S. melanostomus & Blackgill rockfish & Lumpenella longirostris & Longsnout prickleback \\
\hline S. paucispinis & Bocaccio & Lumpenus fabricii & Slender eelblenny \\
\hline S. pinniger & Canary rockfish & L. macularus & Daubed shanny \\
\hline S. polyspinis & Northern rockfish & L. sagitta & Snake prickleback \\
\hline
\end{tabular}




\begin{tabular}{|c|c|c|c|}
\hline Species & Common name & Species & Common name \\
\hline $\begin{array}{l}\text { Class Osteichthyes (Continued) } \\
\text { Order Perciformes (Continued) } \\
\text { Zaproridae } \\
\text { Zaprora silenus } \\
\text { Trichodontidae } \\
\text { Trichodon trichodon } \\
\text { Ammodytidae } \\
\text { Ammodytes hexapterus } \\
\text { Order Pleuronectiformes } \\
\text { Paralichthyidae } \\
\text { Citharichihys sordidus } \\
\text { Pleuronectidae } \\
\text { Atheresthes evermanni } \\
\text { A. stomias } \\
\text { Eopsetta exilis }\end{array}$ & $\begin{array}{l}\text { Prowfish } \\
\text { Pacific sandfish } \\
\text { Pacific sand lance } \\
\text { Pacific sanddab } \\
\text { Kamchatka flounder } \\
\text { Arrowtooth flounder } \\
\text { Slender sole }\end{array}$ & $\begin{array}{l}\text { E. jordani } \\
\text { Errex zachirus }{ }^{15} \\
\text { Hippoglossoides elassodon } \\
\text { H. robustus } \\
\text { Hippoglossus stenolepis } \\
\text { Microstomus pacificus } \\
\text { Platichthys stellatus } \\
\text { Pleuronectes asper }{ }^{15} \\
\text { P. bilineatus }{ }^{15} \\
\text { P. isolepis }{ }^{15} \\
\text { P. proboscideus } 15 \\
\text { P. quadrituberculatus } \\
\text { P. vetulus }{ }^{15} \\
\text { Psettichthys melanostictus } \\
\text { Reinharditus hippoglossoides }\end{array}$ & $\begin{array}{l}\text { Petrale sole } \\
\text { Rex sole } \\
\text { Flathead sole } \\
\text { Bering flounder } \\
\text { Pacific halibut } \\
\text { Dover sole } \\
\text { Starry flounder } \\
\text { Yellowfin sole } \\
\text { Rock sole } \\
\text { Butter sole } \\
\text { Longhead dab } \\
\text { Alaska plaice } \\
\text { English sole } \\
\text { Sand sole } \\
\text { Greenland halibut }\end{array}$ \\
\hline \multicolumn{4}{|c|}{$\begin{array}{l}\text { 1'Unless otherwise noted, common names are from Robins (1980) and the scientific names from Eschmeyer and Herald (1983). Higher taxa and their sequential order } \\
\text { are from Nelson, J.S. (1984) except for Gadiformes, which follows Cohen (1984) and Scorpaeniformes, which is modified in part by Yabe (1985). Paralichthyidae (=Bothidae, } \\
\text { in part) is from Ahlstrom et al. (1984a). } \\
{ }^{2} \text { Probably includes Alaska skate, Barhyraja parmifera, and starry skate, Raja stellulata. } \\
{ }^{3} \text { Peden (198l) } \\
{ }^{4} \text { Fedorov (1973b) } \\
{ }^{5} \text { Eschmeyer and Heraid (1983) } \\
{ }^{6} \text { Ichthyological Society of Japan (198I) } \\
{ }^{7} \text { May include the Alaska snailfish, Careproctus colletti; blackfinned snailfish. C. cypselurus; forktail snailfish, C. furcellus; and biacktail snailfish, C. melanurus. } \\
{ }^{8} \text { May include the pink snailfish, Careproctus osborni; monster snailfish, C. phasma; salmon snailfish, C. rastrinus; and peachskin snailfish, C. scontre. } \\
{ }^{9} \text { Kessler (1985) } \\
{ }^{10} \text { Dina (1978) } \\
{ }^{11} \text { Yabe (1985) } \\
{ }^{12} \text { Peden (1978) } \\
{ }^{13} \text { New common name. } \\
{ }^{14} \text { This species was recorded in the data as Lycodes soldatovi. E. M. Anderson (Dep. Ichthyol., Calif. Acad. Sci., San Francisco, CA } 94118 \text {, pers. commun. April 1984) } \\
\text { considers this species to be a junjor synonym of Lycodes concolor. } \\
{ }^{15} \text { Sakamoto (1984) }\end{array}$} \\
\hline
\end{tabular}

\section{Table 4}

The 25 most common fish species, from the Chukchi Sea and Bering Sea to southern California, in order of frequency of occurrence in surveys. Total number of samples $=\mathbf{2 4 , 8 8 1}$.

\begin{tabular}{|c|c|c|c|}
\hline Rank & Species & Frequency & $\begin{array}{l}\text { Percent } \\
\text { frequency }\end{array}$ \\
\hline 1 & Walleye pollock, Theragra chalcogramma & 14,912 & 59.9 \\
\hline 2 & Arrowtooth flounder, Atheresthes stomias & 13,004 & 52.3 \\
\hline 3 & Flathead sole, Hippoglossoides elassodon & 12,676 & 50.9 \\
\hline 4 & Pacific cod, Gadus macrocephalus & 12,402 & 49.8 \\
\hline 5 & Pacific halibut, Hippoglossus stenolepis & 9,719 & 39.1 \\
\hline 6 & Rock sole, Pleuronectes bilineatus & 8,720 & 35.0 \\
\hline 7 & Rex sole, Errex zachinus & 8,133 & 32.7 \\
\hline 8 & Sablefish, Anoplopoma fimbria & 7,259 & 29.2 \\
\hline 9 & Yellowin sole, Pleuronectes asper & 6,978 & 28.0 \\
\hline 10 & Dover sole, Microstomus pacificus & 5,142 & 20.7 \\
\hline \multirow{2}{*}{11} & Greenland halibut, Reinhardtius & & \\
\hline & hippoglossoides & 4,811 & 19.3 \\
\hline 12 & Alaska plaice, Pleuronectes quadrituberculatus & 4,780 & 19.2 \\
\hline 13 & Pacific ocean perch, Sebastes alutus & 4,378 & 17.6 \\
\hline 14 & Yellow Irish lord, Hemilepidotus jordani & 4,000 & 16.1 \\
\hline 15 & Pacific herring, Clupea pallasii & 3,409 & 13.7 \\
\hline 16 & Eulachon, Thaleichthys pacificus & 3,104 & 12.5 \\
\hline 17 & Shortspine thornyhead, Sebastolobus alascanus & 3,024 & 12.2 \\
\hline 18 & Sturgeon poacher, Podothecus acipenserinus & 2.916 & 11.7 \\
\hline 19 & Spinyhead sculpin, Dasycorrus setiger & 2,802 & 11.3 \\
\hline 20 & Bigmouth sculpin, Hemitripterus bolini & 2,712 & 10.9 \\
\hline 21 & Wattled eelpout, Lycodes palearis & 2,477 & 10.0 \\
\hline 22 & Capelin, Mallotus villosus & 2,345 & 9.4 \\
\hline 23 & Shortfin eelpout, Lycodes brevipes & 2,236 & 9.0 \\
\hline 24 & Rougheye rockfish, Sebastes aleutianus & 2,151 & 8.6 \\
\hline \multirow[t]{2}{*}{25} & Great sculpin, Myoxocephalus & & \\
\hline & polyacanthocephalus & 2,133 & 8.6 \\
\hline
\end{tabular}


Literature Reported from southeast Alaska to Sebastian Vizcaino Bay, Baja California, and in the northern part of the Gulf of California (Miller and Lea 1972; Eschmeyer and Herald 1983), at depths of 0 to $913 \mathrm{~m}$ (Dean 1906; Eschmeyer and Herald 1983).

Survey data Found from Cape Spencer in southeast Alaska to Oxnard, California. Depth range 25 to $575 \mathrm{~m}$, greatest frequency of occurrence $(27.4 \%)$ on the outer shelf between 100 and $150 \mathrm{~m}$, and $95.0 \%$ from 50 to $400 \mathrm{~m}$ in depth. Survey data provide a more specific northern limit of the range.

\section{Conclusions}

Zoogeography Oregonian-Californian

Life zone Middle shelf-mesobenthai (outer shelf)

Range Cape Spencer, Alaska, to Sebastian Vizcaino Bay, Baja California, and the northern Gulf of California

Depth $\quad 0$ to $913 \mathrm{~m}$

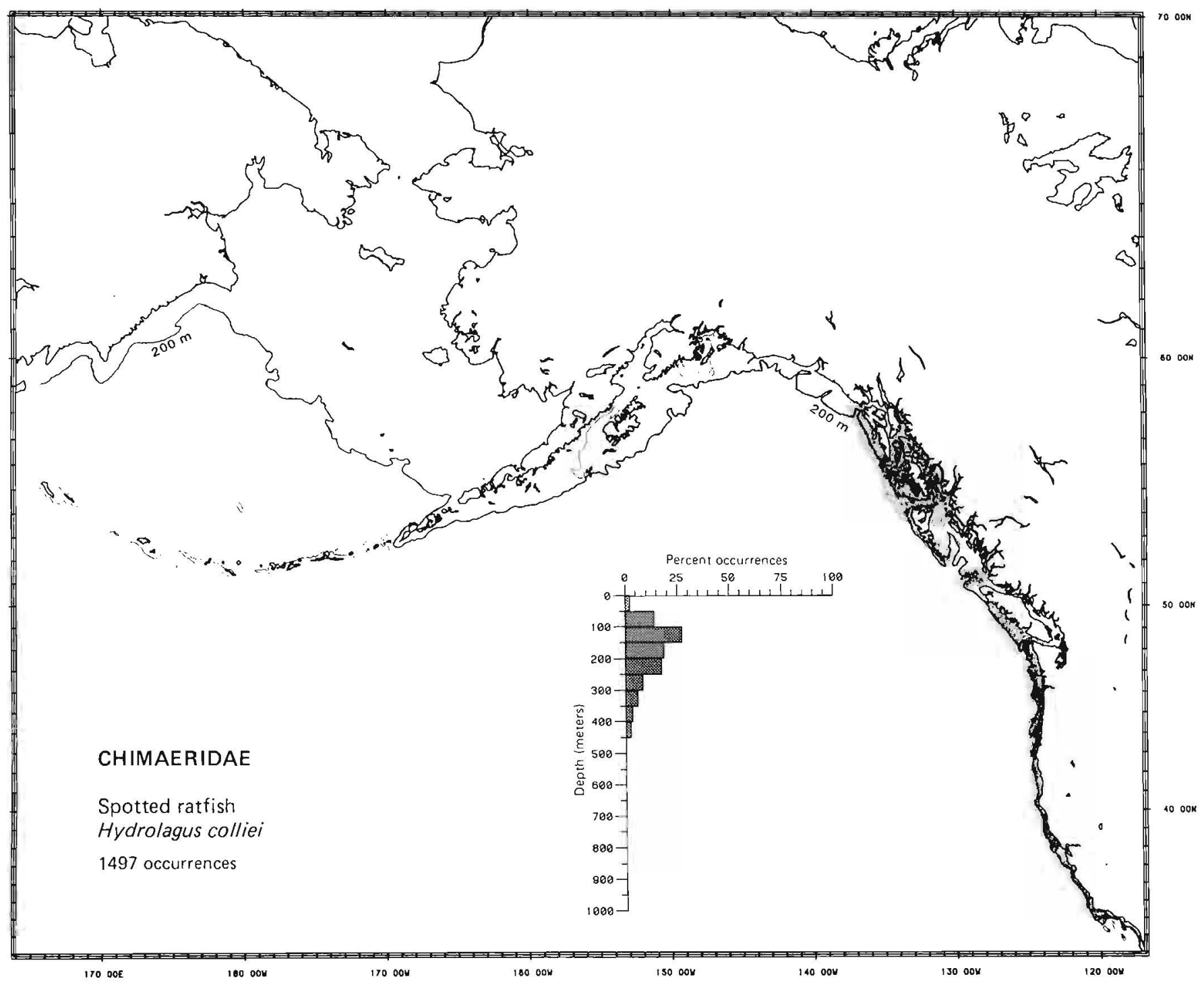


Literature Found in predominantly temperate regions in both Northern and Southern Hemispheres. In the North Pacific, from the Bering Sea to central Baja California (and possibly the Gulf of California) in the east (Miller and Lea 1972; Hart 1973; Compagno 1984); from eastern Kamchatka and the Sea of Okhotsk to the southwestern Yellow Sea off China in the west (Bigelow and Schroeder 1957; Jones and Geen 1976; Compagno 1984). Occurs along the Aleutians to Attu Island (Okada and Kobayashi 1968). In the North Atlantic, from southern Greenland and southeastern Baffin Island to Cuba in the west and from the Murman Coast of the Barents Sea and Iceland south to Senegal and the Canary Islands, including the Mediterranean and Black Seas, in the east (Bigelow and Schroeder 1957). In the Southern Hemisphere, along Africa south of lat. $27^{\circ} \mathrm{S}$ (at least in the west; Bass et al. 1976), Reunion Island (Bigelow and Schroeder 1957), southeastern and southern Australia, Tasmania, possibly Papua-New Guinea, New Zealand, Chile, Argentina, and Uruguay (Bigelow and Schroeder 1957; Jones and Geen 1976; Compagno 1984). Depth range reported from the surface and intertidal to $900 \mathrm{~m}$ (Compagno 1984).

Survey data Found from Zhemchug Canyon on the central slope of the eastern Bering Sea and Unalaska Island in the Aleutian Islands south to San Nicolas Island in southern California; in the Bering Sea, found discontinuously along the outer shelf and slope in the southeast. Depth range 25 to $575 \mathrm{~m}$; most occurrences $(29.4 \%$ ) on the outer shelf between 100 and $150 \mathrm{~m}$, and $95.9 \%$ from depths of $\leqslant 350 \mathrm{~m}$. These data add more detailed information on distribution in the Bering Sea and provide a northern limit in the northeastern Pacific.

\section{Conclusions}

\section{Zoogeography Antitropical-temperate}

Life zone Inner shelf-mesobenthal (outer slope)

Range In temperate regions in the North Atlantic and Pacific, and off South America, southern Africa, Reunion Island, Australia, and New Zealand. In the North Pacific from the coast of China (southwestern Yellow Sea) to Zhemchug Canyon in the Bering Sea, west in the Aleutian Islands to Attu Island, and south to central Baja California (and possibly the Gulf of California).

Depth From intertidal and surface to $900 \mathrm{~m}$

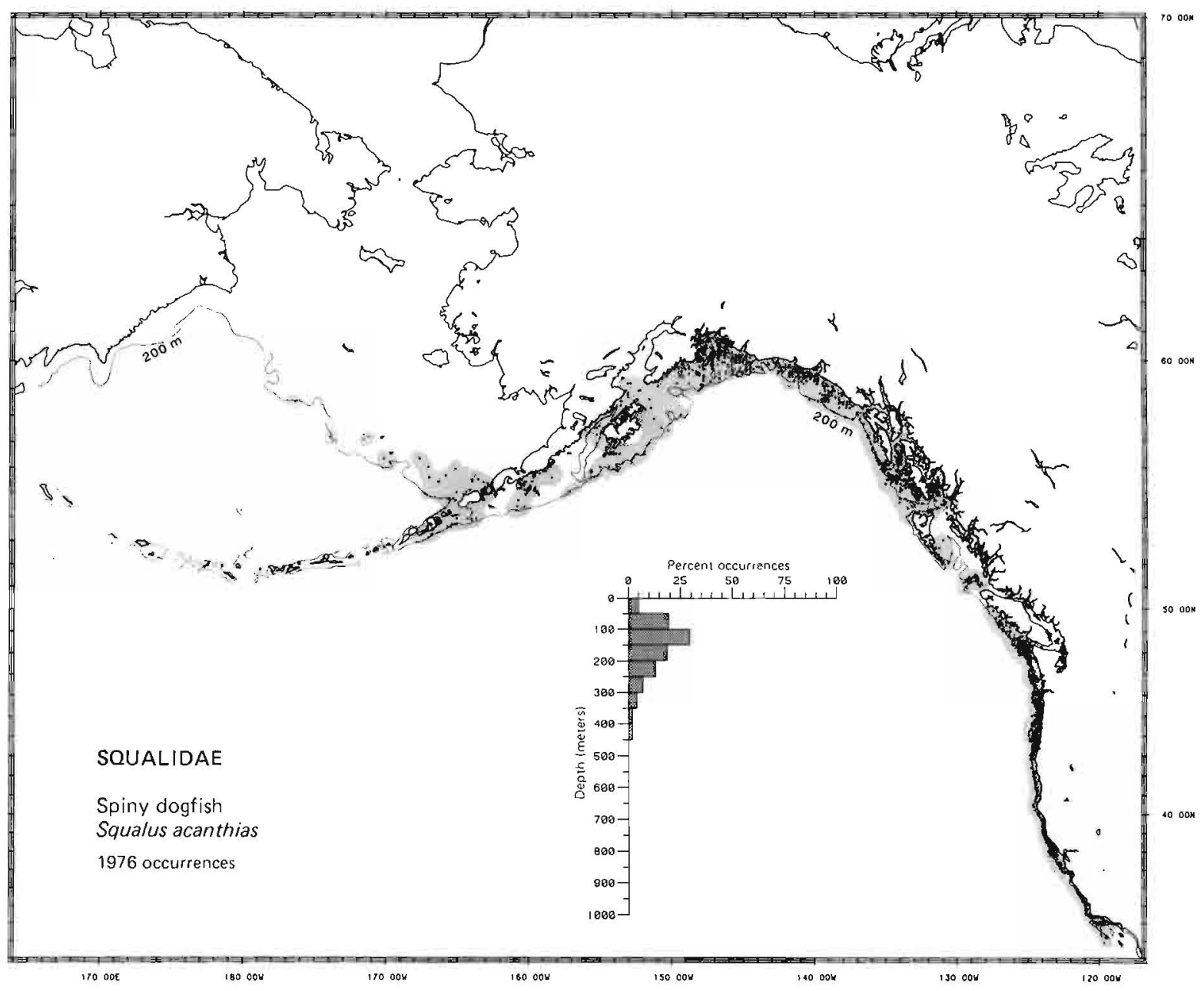


Literature Reported from Dixon Entrance, British Columbia, to Sebastian Vizcaino Bay, Baja California (Miller and Lea 1972; Hart 1973), at depths of 0 to $274 \mathrm{~m}$ (Howe 1981; Eschmeyer and Herald 1983).

Survey data Found from Cape Flattery, Washington, to Oxnard, California. Depth range 25 to $425 \mathrm{~m}$; found most frequently (28.7\% of occurrences) on the outer shelf between 100 and $150 \mathrm{~m}$, and $98.0 \%$ of occurrences from depths of 50 to $400 \mathrm{~m}$. Although survey data were all within the known geographic range, the survey maximum depth of $425 \mathrm{~m}$ is a new record.

\section{Conclusions}

Zoogeography Oregonian-San Diegan

Life zone Middle shelf-mesobenthal (outer shelf)

Range $\quad$ From Dixon Entrance, British Columbia, to Sebastian Vizcaino Bay, Baja California

Depth 0 to $425 \mathrm{~m}$

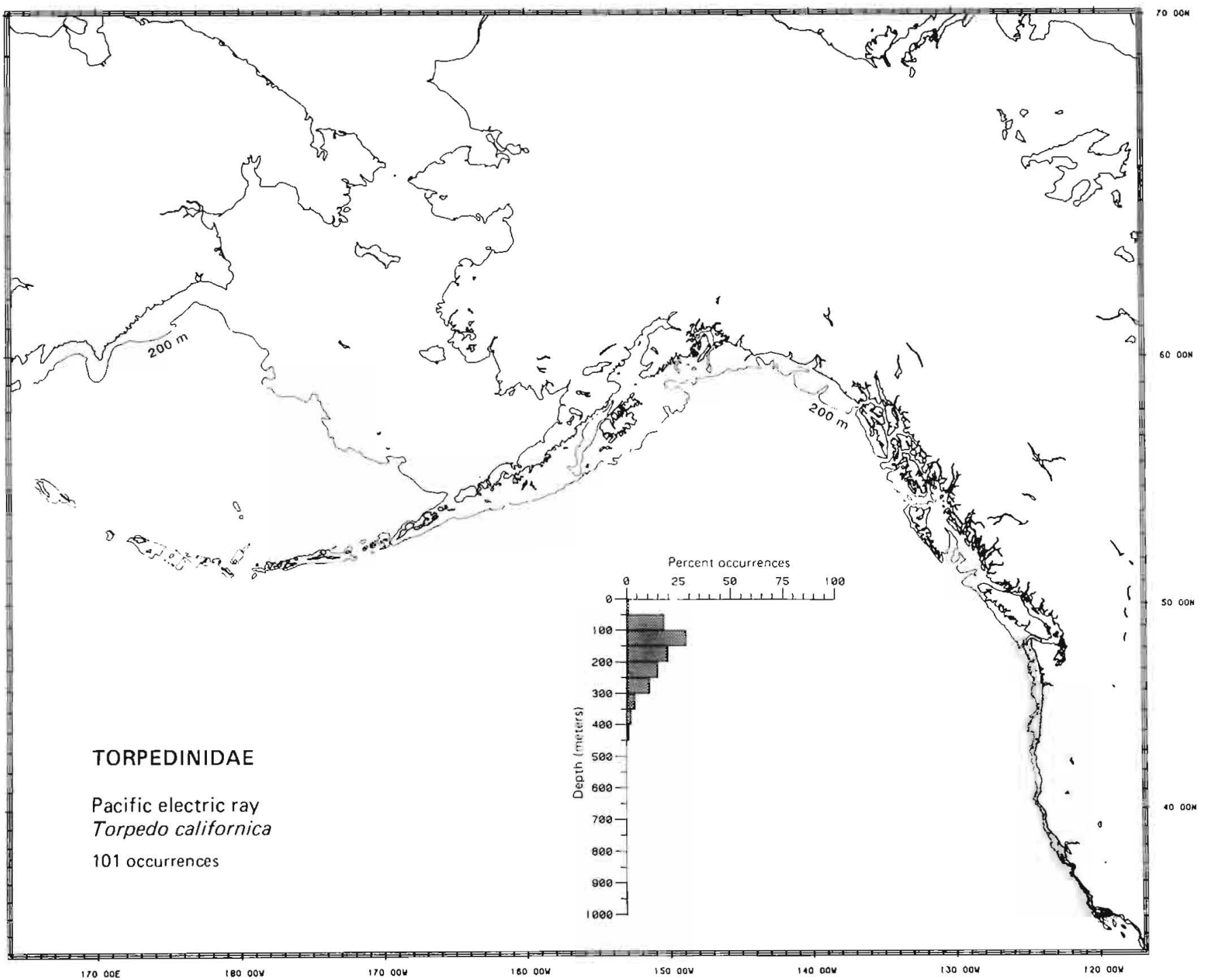


Taxonomic comment The Bering skate is Raja interrupta in Robins (1980), but has been placed in the genus Bathyraja by others more recently (e.g., Eschmeyer and Herald 1983; Ishihara and Ishiyama 1985). Ishihara and Ishiyama (1985) regard the sandpaper skate, Bathyraja (=Raja) kincaidii, to be the same species as the Bering skate, with Bathyraja kincaidii being a junior synonym of Bathyraja interrupta. In addition, an undescribed species, generally included with Bathyraja kincaidii, may also occur in the northeastern Pacific (J. D. McEachren, Dep. Wildl. Fish. Sci., Texas A\&M Univ., College Station, TX 77843-2258, pers. commun. August 1983).

Literature Reported from the Bering Sea off Cape Navarin and Unalaska Island to Cortez Bank off southern California (Hart 1973; Howe 1981; Eschmeyer and Herald 1983; Ishihara and Ishiyama 1985) and in depth from 54 to $1380 \mathrm{~m}$ (Miller and Lea 1972; Howe 1981).

Survey data Found from the western Bering Sea off Cape Navarin and Agattu Island in the Aleutian Islands to Santa Barbara, California. In the Bering Sea, along the outer shelf. Depth range 25 to $725 \mathrm{~m}$, most commonly (24.9\% of occurrences) on the outer shelf between 100 and $150 \mathrm{~m}$, and $97.5 \%$ of occurrences from depths of 50 to $450 \mathrm{~m}$. Survey data extend the known range of this species along the Aleutian Islands, define its range in the Bering Sea, and extend its known range into more shallow water. However, the undescribed species may be included in the survey data (especially in the south) and, in the Bering Sea, other species of skates, such as the Alaska skate, Bathyraja parmifera, or Aleutian skate, Bathyraja aleutica, may have been confused with this species. Further study is needed on the systematics of this and other Bathyraja species to clarify their actual distribution.

\section{Conclusions}

Zoogeography Eastern boreal Pacific

Life zone Middle shelf-mesobenthal (outer shelf)

Range $\quad$ From off Cape Navarin in the western Bering Sea and Agattu Island in the Aleutian Islands to Cortez Bank, California

Depth $\quad 25$ to $1380 \mathrm{~m}$

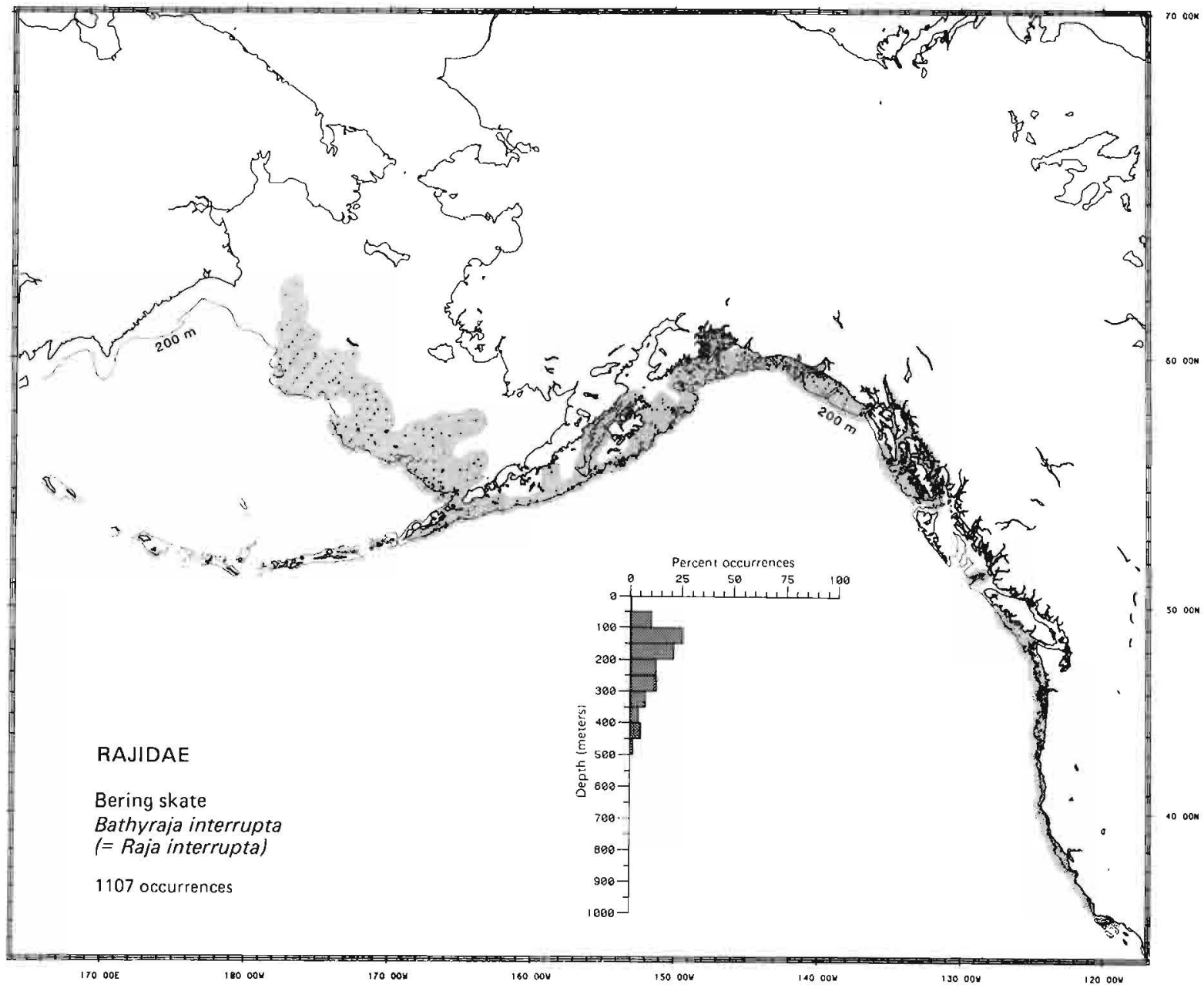


Literature Reported from the Bering Sea and Amchitka Island in the Aleutian Islands to Cedros Island, Baja California (Miller and Lea 1972; Simenstad et al. 1977; Eschmeyer and Herald 1983), at depths of 3 to $800 \mathrm{~m}$ (Howe 1981; Eschmeyer and Herald 1983).

Survey data Found from northeast of Cape Navarin to Glubokaya Bay in the western Bering Sea, along the outer shelf of the eastern Bering Sea, and along the Aleutian Islands to Stalemate Bank; occurred in survey catches from the Aleutians south to Santa Barbara, California. Depth range 25 to $725 \mathrm{~m}$, most frequently (in $29.4 \%$ of occurrences) on the outer shelf from 100 to $150 \mathrm{~m}$, and $96.1 \%$ of occurrences from depths $<350 \mathrm{~m}$. Although the survey data extend the known range of this species along the length of the Aleutian Islands and define its distribution in the Bering Sea, the Aleutian skate, Bathyraja aleutica, may have been confused with this species in these areas.

\section{Conclusions}

Zoogeography Eastern boreal Pacific

Life zone Inner shelf mesobenthal (outer shelf)

Range From Glubokaya Bay, Cape Navarin, and Stalemate Bank to Cedros Island, Baja California

Depth 3 to $800 \mathrm{~m}$

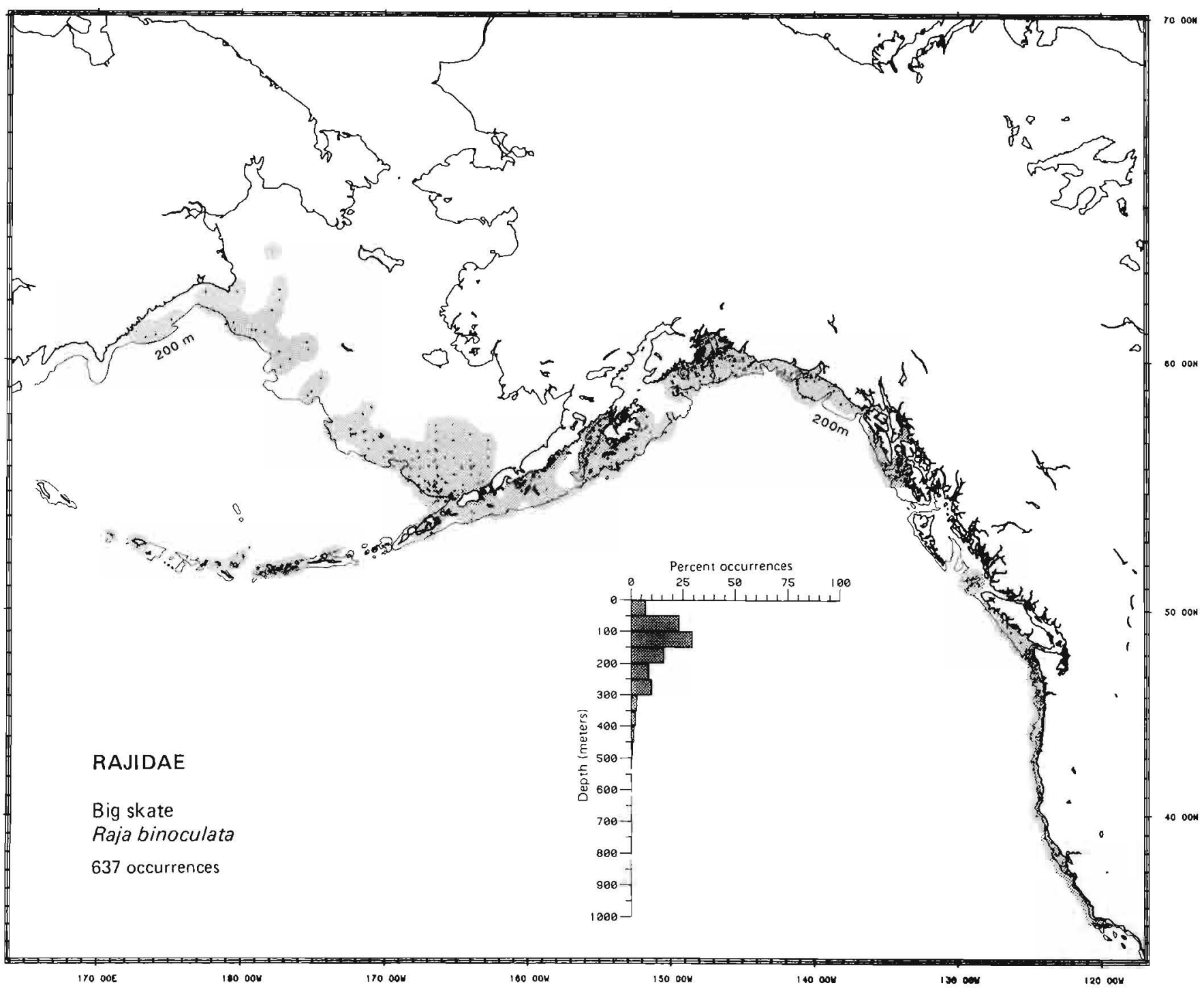


Literature Reported from the southeastern Bering Sea to Cedros Island, Baja California (Miller and Lea 1972; Kessler 1985), and from 55 to $622 \mathrm{~m}$ in depth (Eschmeyer and Herald 1983).

Survey data Found from Navarin Canyon in the eastern Bering Sea and Unalaska Island in the Aleutian Islands to the Patton Escarpment off San Nicolas Island in southern California. Depth range 25 to $675 \mathrm{~m}$, most frequently $(31.2 \%$ of occurrences) on the outer shelf between 100 and $150 \mathrm{~m}$, and $96.6 \%$ of occurrences from depths $\leqslant 350 \mathrm{~m}$. Survey data extend the known distribution of this species into the Bering Sea and slightly expand the known depth range of the species. However, the Aleutian skate, Bathyraja aleutica, may have been confused with this species in the Bering Sea.

\section{Conclusions}

Zoogeography Eastern boreal Pacific

Life zone Inner shelf-mesobenthal (outer shelf)

Range From Navarin Canyon in the Bering Sea and Unalaska Island in the Aleutian Islands to Cedros Island, Baja California

Depth 25 to $675 \mathrm{~m}$ (new depth range)

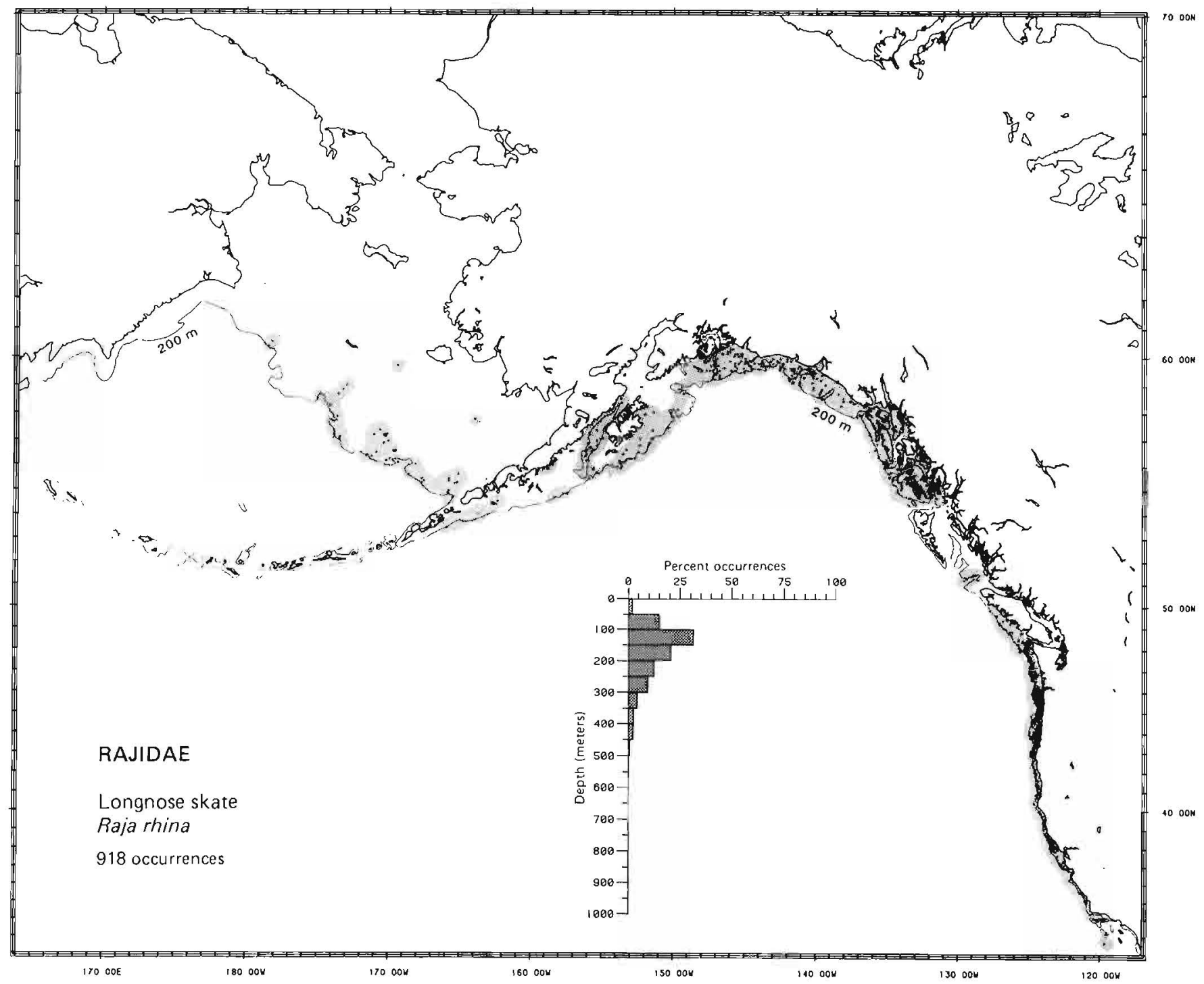


Taxonomic comment This complex includes at least two species: the Alaska skate, Bathyraja parmifera (Bean 1881), and the starry skate, Raja stellulata Jordan and Gilbert 1880, which have been called "starry skate" in the field. Field characters used for distinguishing the two species have only recently been well described (see Eschmeyer and Herald 1983).

Literature The starry skate has been reported from the Bering Sea and Unalaska Island to northern Baja California at depths of 18 to $732 \mathrm{~m}$ (Wilimovsky 1964; Eschmeyer and Herald 1983). The Alaska skate has been reported from the western Bering Sea and Amchitka Island to southeastern Alaska at depths of 18 to $1000 \mathrm{~m}$ (Andriyashev 1939; Fedorov 1973a; Simenstad et al. 1977; Eschmeyer and Herald 1983; Baxter 1985).

Survey data Taken in surveys from Cape Navarin in the western Bering Sea and west of the Delarof Islands in the Aleutian Islands to Point Reyes, California. Depth range 25 to $675 \mathrm{~m}$, most frequently (48.8\% of occurrences) on the middle shelf between 50 and 100 $\mathrm{m}$, and $94.9 \%$ of occurrences from depths $\leqslant 200 \mathrm{~m}$. Survey data for this complex of species cannot be used to describe range limits; however, the data do show the distribution of this complex in the Bering Sea, and may be of use to future taxonomic and ecological studies. Most records of this complex in the Bering Sea and Aleutian Islands are probably of Alaska skate, and most south of southeastern Alaska are probably starry skate. Relative abundance of the two species in the Gulf of Alaska is not known at present, although the Alaska skate is probably the more abundant species.

Conclusions "Starry skate" complex consists of two or more boreal Pacific, sublittoral species that need to be accurately identified in field collections before any conclusion concerning the distribution of the individual species can be reached.

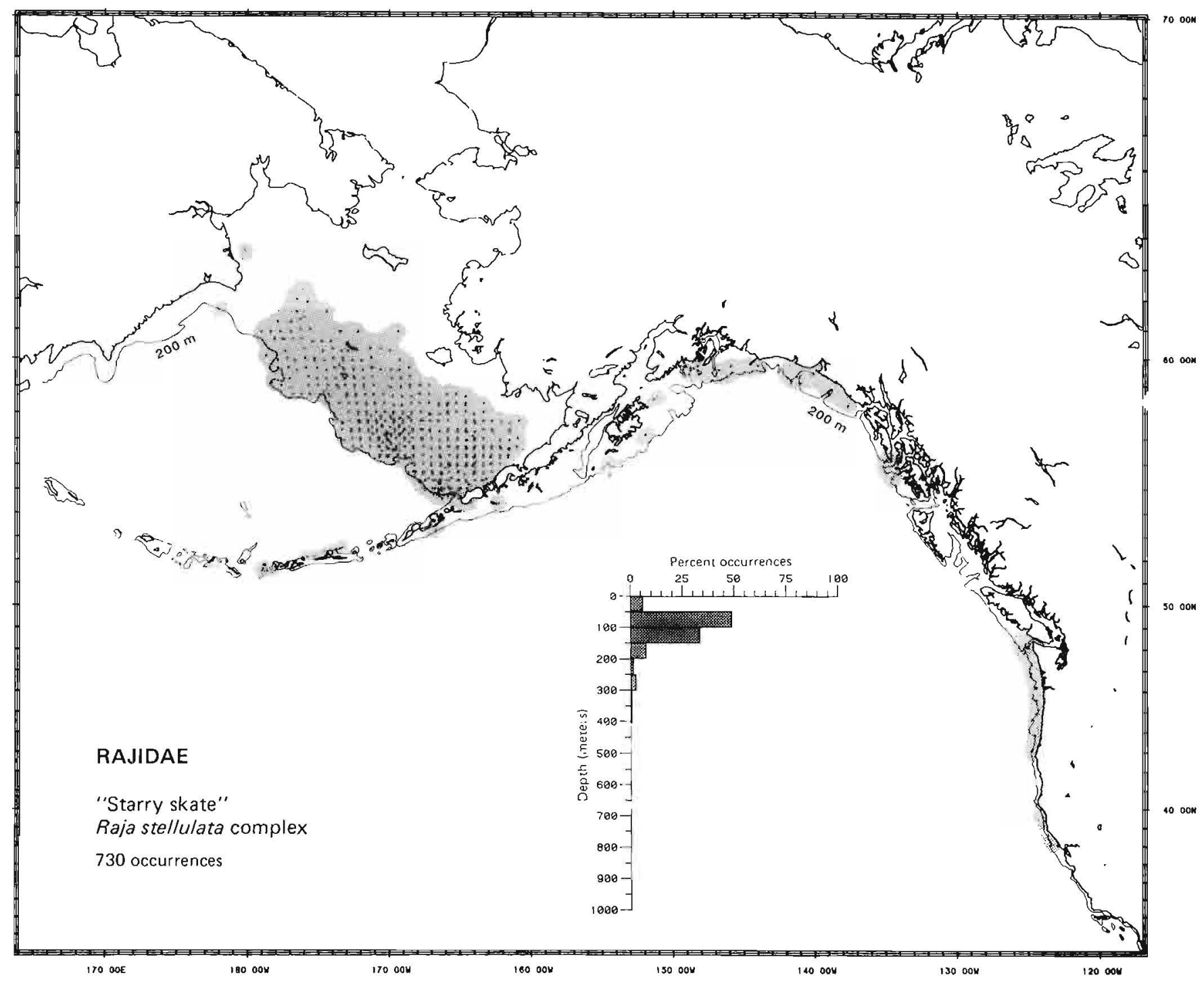


Literature Original range of this species is in the western North Atlantic from Sand Hill River, Labrador, to Indian River, Florida (Lee et al. 1980; Morrow 1980). The species is pelagic and anadromous, traveling more than $600 \mathrm{~km}$ up some east coast rivers (Hildebrand 1963; Moyle 1976). It was introduced to the Sacramento River, California, in 1871-81 and has spread in the North Pacific to Kamchatka and the Bering Sea in the north and to Todos Santos Bay, Baja California, in the south (Lee et al, 1980; Howe 1981). It is landlocked in Millerton Lake, California (Lee et al. 1980). The species has been reported from the surface to $183 \mathrm{~m}$ in depth (Howe 1981).

Survey data Found from southwestern Vancouver Island to Monterey Bay, California. Depth range 25 to $375 \mathrm{~m}$, most frequently (49.5\% of occurrences) on the outer shelf from 100 to $150 \mathrm{~m}$, and $97.4 \%$ of occurrences from 50 to $250 \mathrm{~m}$ in depth. Survey data occur within the known geographic range, but include a greater maximum depth. However, because this species is epipelagic in the ocean and most of the survey samples were taken by bottom trawls, the species may have been taken near the surface but recorded at a greater depth.

\section{Conclusions}

Zoogeography Amphiboreal American (western boreal Atlantic-northeastern boreal Pacific)

Life zone Fluvial-oceanic (neritic)

Range From Sand Hill River, Labrador to Indian River, Florida, in the Atlantic, and from Kamchatka to Todos Santos Bay,

Depth Surface to $250 \mathrm{~m}$, possibly to $375 \mathrm{~m}$

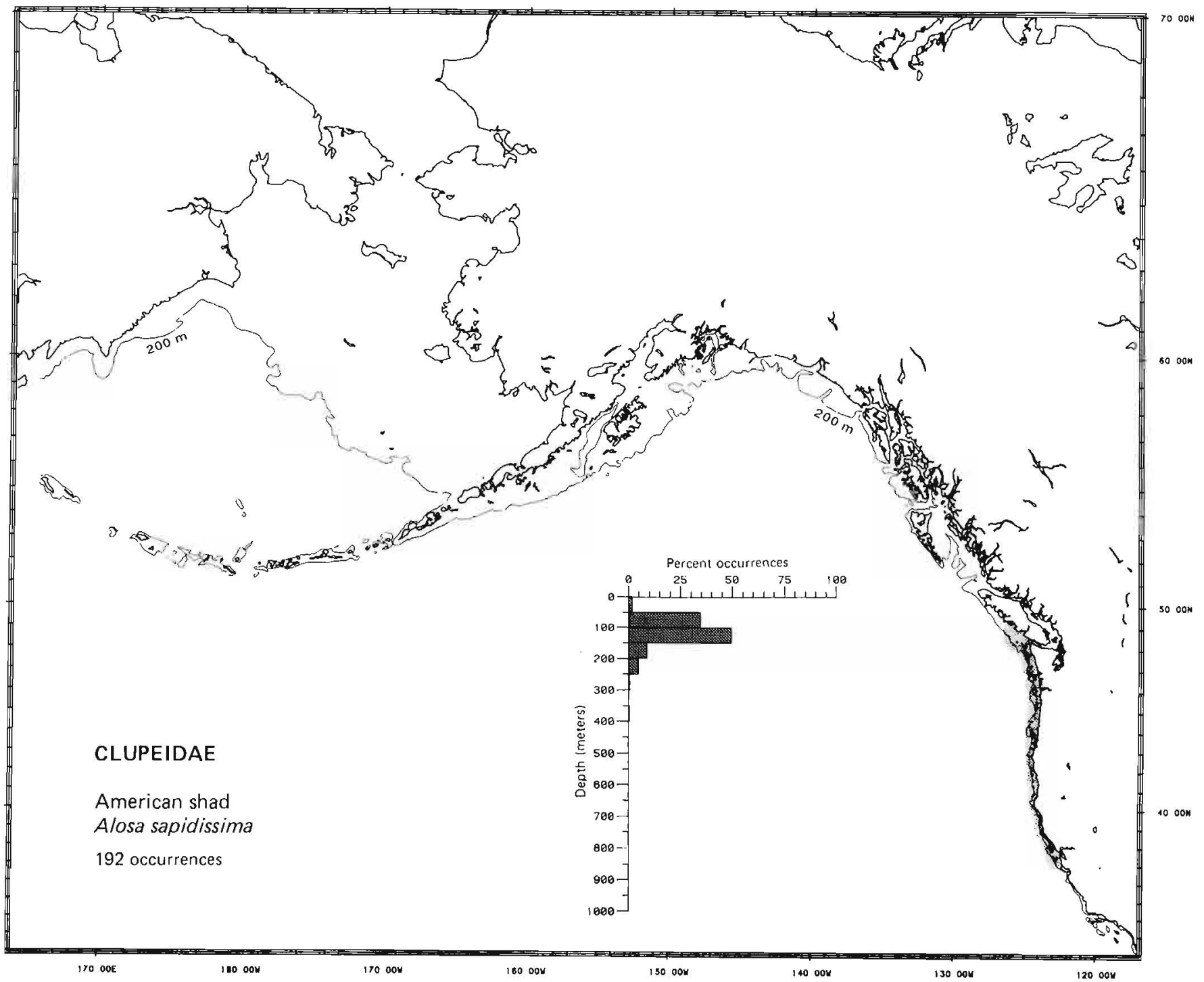


Taxonomic comment Regarded as Clupea harengus pallasi in Robins (1980) and, thus, a subspecies of the Atlantic herring, Clupea harengus Linnaeus 1758. Based on genetic differences, Grant (1986) considered the Atlantic and Pacific herring to be distinct species. The correct species name is pallasii rather than pallasi (Jordan and Evermann 1896-1900).

Literature In the North Pacific, the Pacific herring ranges from western Korea and the Sea of Okhotsk to the Bering Sea and south to Ensenada, Baja California (Hart 1973; Fitch and Lavenberg 1975). From the Bering Sea, into the Arctic, west to the White Sea, U.S.S.R., and east to the Coppermine River, Canada (Andriyashev 1954). In the Aleutian Islands, as far west as Adak Island (Wilimovsky 1964). Reported from the surface to $300 \mathrm{~m}$ (Andriyashev 1954). It is pelagic and also occurs in estuaries as far as the Oligohaline Zone (Moyle 1976; Simenstad 1983).

Survey data Found near Bering Island and from Cape Olyutorski to Anadyr Bay in the western Bering Sea, north of Cape Lisburne in the Chukchi Sea, throughout the eastern Bering Sea, and from Akutan Island in the Aleutian Islands south to Point San Luis, California. Depth range 25 to $475 \mathrm{~m}$, most frequently (41.9\% of occurrences) on the middle shelf from 50 to $100 \mathrm{~m}$, and $94.6 \%$ of occurrences from depths $\leqslant 150 \mathrm{~m}$. Survey data were within the known range, but provide a greater maximum depth for this species. However, because the Pacific herring is pelagic and surveys were conducted with bottom trawls and other nets, the species may have been taken near the surface but recorded at a greater depth.

\section{Conclusions}

Zoogeography Arctic-circumboreal Pacific

Life zone Estuarine-epipelagic (neritic)

Range From the White Sea, U.S.S.R., and the Coppermine River, Canada, in the Arctic to western Korea and northern Baja California in the Pacific

Depth Surface to $150 \mathrm{~m}$, possibly to $475 \mathrm{~m}$

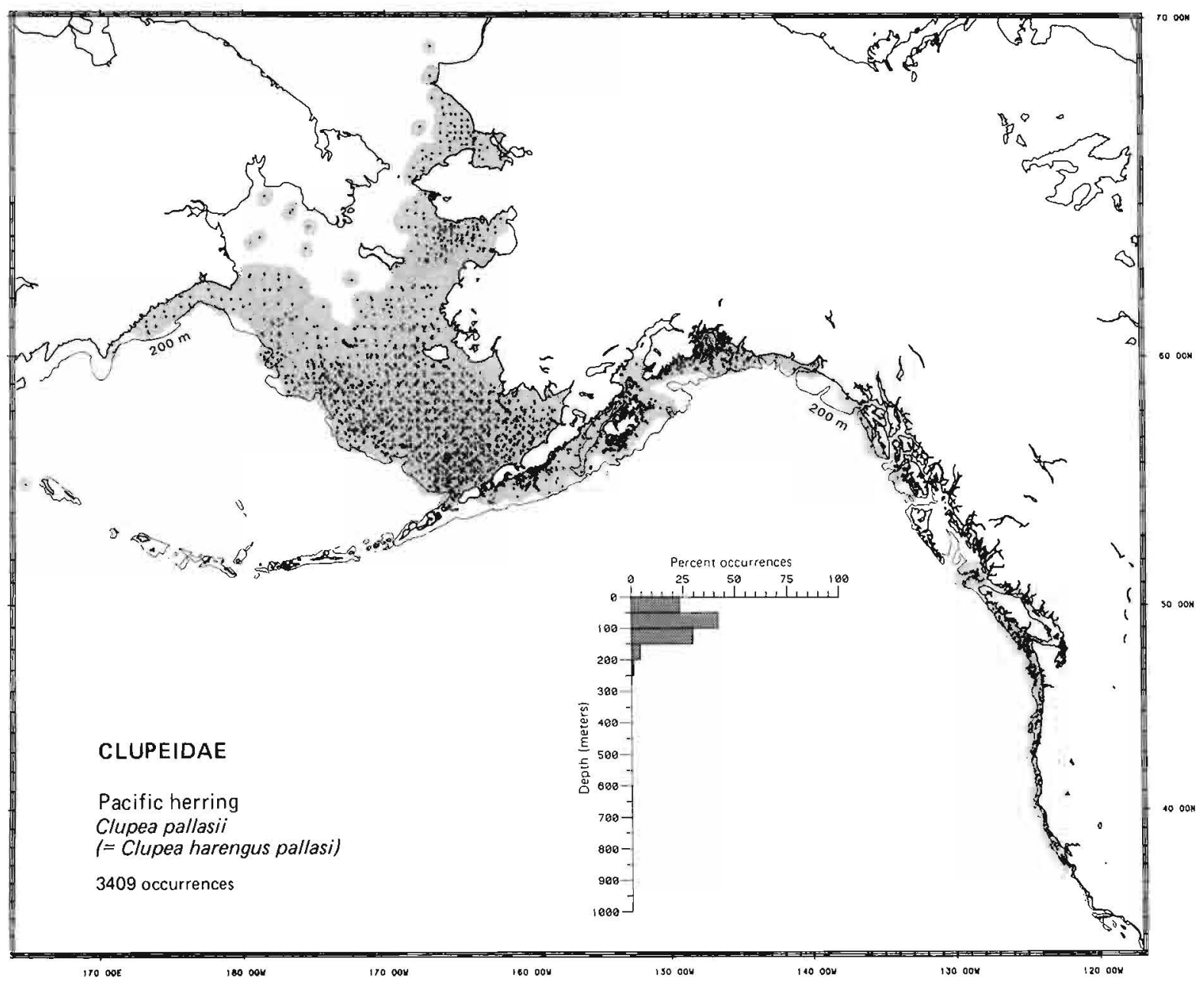


Taxonomic comment Regarded as a subspecies of the California smoothtongue, Leuroglossus stilbius Gilbert 1890, during much of the period covered by these surveys; hence this species was called California smoothtongue in the field. Peden (1981) presented evidence to separate the northern and California smoothtongue as distinct species. The California smoothtongue is Bathylagus stilbius in Robins (1980). Dunn (1983) presented detailed evidence for placing the two species in the genus Leuroglossus. Ahlstrom et al. (1984b), however, continue to regard the two species as Bathylagus.

Literature Reported from southeastern Hokkaido, Japan, and the Sea of Okhotsk to southern Vancouver Island, British Columbia (Borodulina 1968; Peden 1981). Species is pelagic and the eggs and larvae are found in the subarctic gyre south to about lat. $47^{\circ} \mathrm{N}$ (Dunn 1983). Reported from the surface to $1800 \mathrm{~m}$ (Fedorov 1973a), although adults are generally found at depths $>150 \mathrm{~m}$ during the day (Peden 1981).

Survey data Taken in surveys along the slope of the eastern Bering Sea from Navarin Canyon to Unimak Island and along the Aleutian Islands to Attu Island; also taken off Baranof Island in southeastern Alaska. Depth range 275 to $975 \mathrm{~m}$, most frequently (15.8\% of occurrences) on the mesobenthal slope between 400 and $450 \mathrm{~m}$, and $96.5 \%$ of occurrences between 250 and $900 \mathrm{~m}$ in depth. Although neither the known geographic nor depth range of this species were extended by the survey data, the depth range of frequent occurrence was more precisely defined. In addition, it should be noted that although the northern smoothtongue is a mesopelagic species, it was captured only along the slope. This probably reflects the distribution of demersal trawl tows rather than the distribution of the species. Few mesopelagic midwater tows were taken over the Aleutian Basin.

\section{Conclusions}

$\begin{array}{ll}\text { Zoogeography } & \text { Oceanic subarctic Pacific } \\ \text { Life zone } & \text { Mesopelagic } \\ \text { Range } & \text { From southeastern Hokkaido north to Navarin Canyon in the Bering Sea and south to southern British Columbia } \\ \text { Depth } & \text { Surface to } 1800 \mathrm{~m}\end{array}$

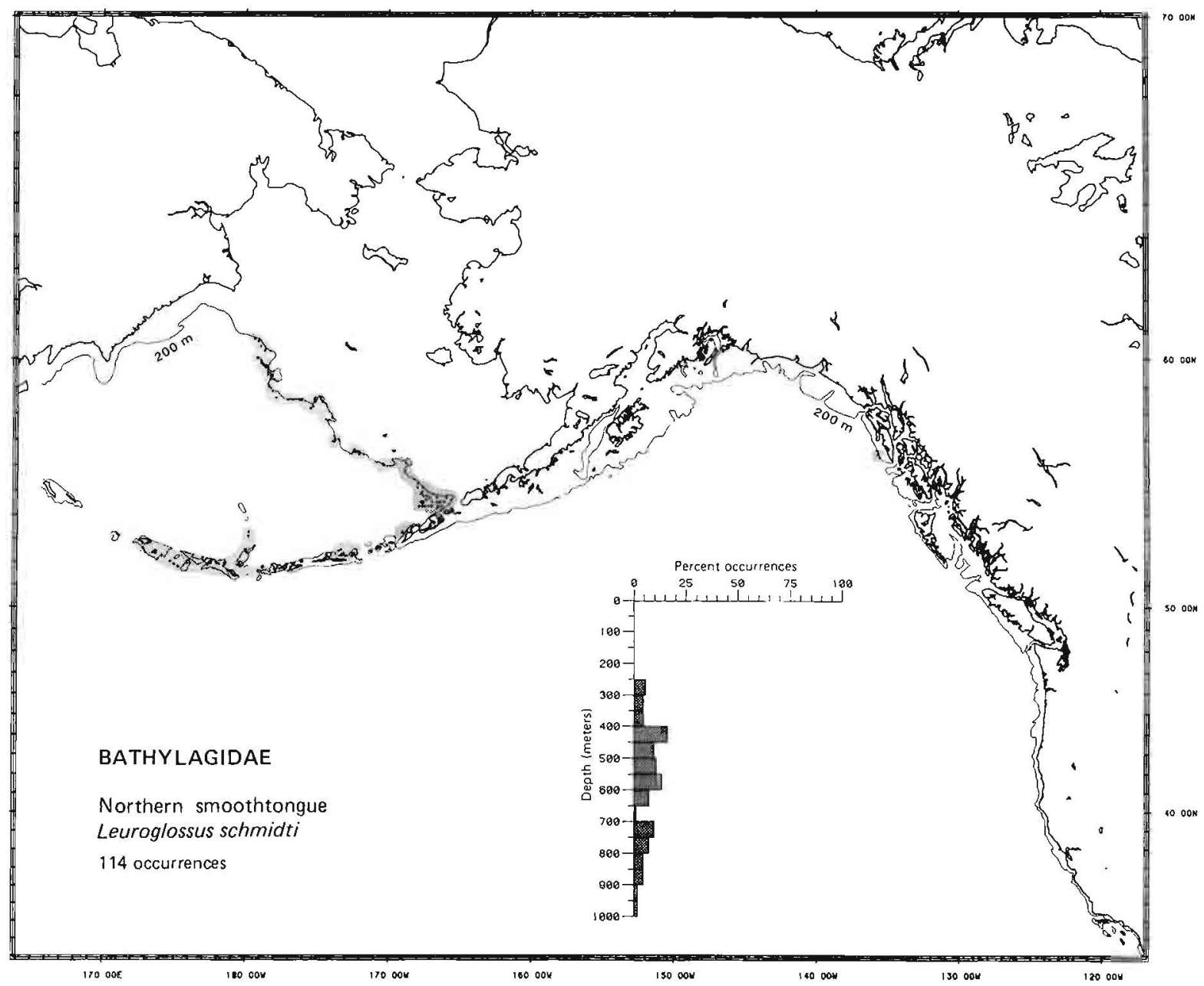


Literature Reported from Korea to the Juan de Fuca Strait between Vancouver Island and Washington in the North Pacific (Eschmeyer and Herald 1983). Range extends from the Bering Sea throughout the Arctic (Muus 1974) except off eastern Siberia (Hart 1973). Occurs in the Aleutians as far west as Attu Island (Wilimovsky 1964); in the North Atlantic, extends south to Maine, southern Greenland, Iceland, and Denmark (Leim and Scott 1966; Wheeler 1969, 1978). A pelagic species reported from the surface to $200 \mathrm{~m}$, and oceanic in the Barents Sea (Andriyashev 1954; Wheeler 1978).

Survey data Found from Cape Nizkiy on the Korak Coast (northeast of Cape Olyutorski) north throughout the Anadyr Gulf in the western Bering Sea and northeast of Cape Lisburne in the Chukchi Sea south throughout the eastern Bering Sea. Taken near Great Sitkin Island in the Aleutian Islands and from there east to Prince of Wales Island in southeastern Alaska. Depth range 25 to $725 \mathrm{~m}, \mathrm{most}$ frequently $(45.2 \%$ of occurrences) on the middle shelf between 50 and $100 \mathrm{~m}$. and $98.5 \%$ of occurrences from depths $<200 \mathrm{~m}$. Survey data do not extend the known geographic range, although they do provide a new maximum depth $(725 \mathrm{~m})$. However, this depth is about $250 \mathrm{~m}$ greater than the next greatest depth of occurrence, and it can probably be assumed that although the trawl was towed at $725 \mathrm{~m}$, the capelin caught were much nearer the surface.

\section{Conclusions}

Zoogeography Arctic-amphiboreal (circumboreal Atlantic northern boreal Pacific)

Life zone Neritic-epipelagic (neritic)

Range Throughout the Arctic south to Korea and the Juan de Fuca Strait in the Pacific and to Maine and Denmark in the North Atlantic

Depth Surface to $200 \mathrm{~m}$, possibly to $725 \mathrm{~m}$

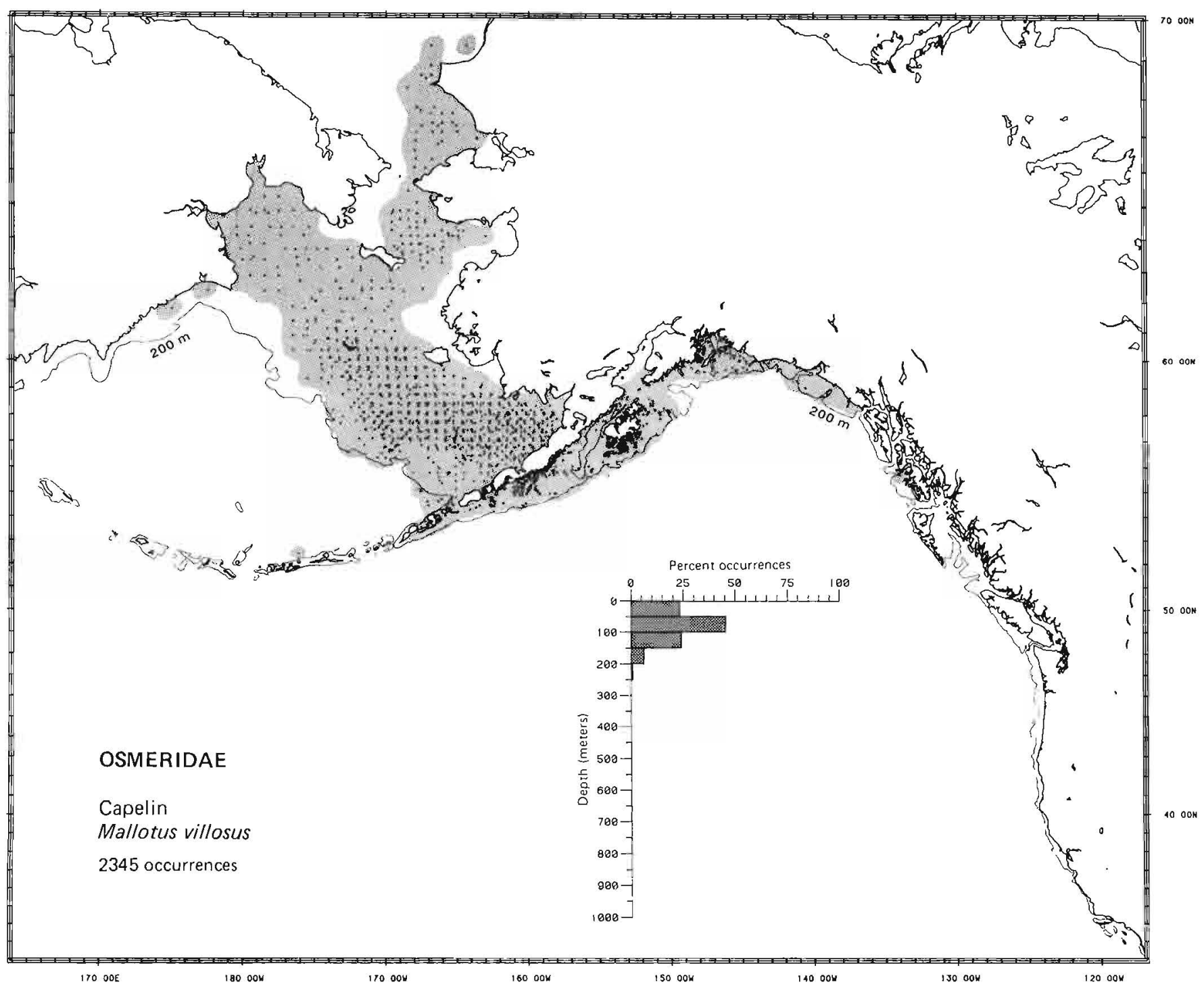


Literature Found in the North Pacific from Wonsan, North Korea, and the Sea of Okhotsk, to Barkley Sound, British Columbia, north along both the Asiatic and American coasts of the Bering Sea to the Arctic (Hart 1973; Lee et al. 1980). Arctic range extends west to the White Sea and east to Bathurst Inlet, Canada. North Atlantic range extends south along the American coast from Lake Melville, Labrador, to the Delaware River, Pennsylvania (and questionably to Virginia), and inland along the Saint Lawrence River to Lake Superior. The rainbow smelt is replaced on the European coast by the European smelt, Osmerus eperlanus Linnaeus 1758 (Lee et al. 1980). A pelagic and anadromous species, migrating up to $1000 \mathrm{~km}$ upstream, with some populations strictly freshwater (Lee et al. 1980; Morrow 1980). Reported to depths of $120 \mathrm{~m}$ (Fedorov 1973a).

Survey data Found from Cape Lisburne in the Chukchi Sea south along the Alaska coast of the Bering Sea to Unalaska Island and east to eastern Kodiak Island, Alaska. Depth range 25 to $425 \mathrm{~m}$, most frequently ( $74.7 \%$ of occurrences) on the inner shelf between 0 and $50 \mathrm{~m}$, and $98.6 \%$ of occurrences from depths $\leqslant 150 \mathrm{~m}$. Survey data were taken within the known geographic range. However, the data extend the maximum known depth to $425 \mathrm{~m}$. Because the species is pelagic and trawls were demersal, the species may have been taken near the surface during deep tows.

\section{Conclusions}

Zoogeography Arctic-amphiboreal (western boreal Atlantic-northern boreal Pacific)

Life zone Fluvial-neritic (neritic)

Range $\quad$ From Wonsan, North Korea, and Barkley Sound, British Columbia, to the Arctic as far as the White Sea and Bathurst Inlet, Canada, and from Lake Melville, Labrador, to the Delaware River, Pennsylvania (and questionably to Virginia), in the North Atlantic; up to $1000 \mathrm{~km}$ upstream in rivers

Depth Surface to at least $150 \mathrm{~m}$, possibly $425 \mathrm{~m}$

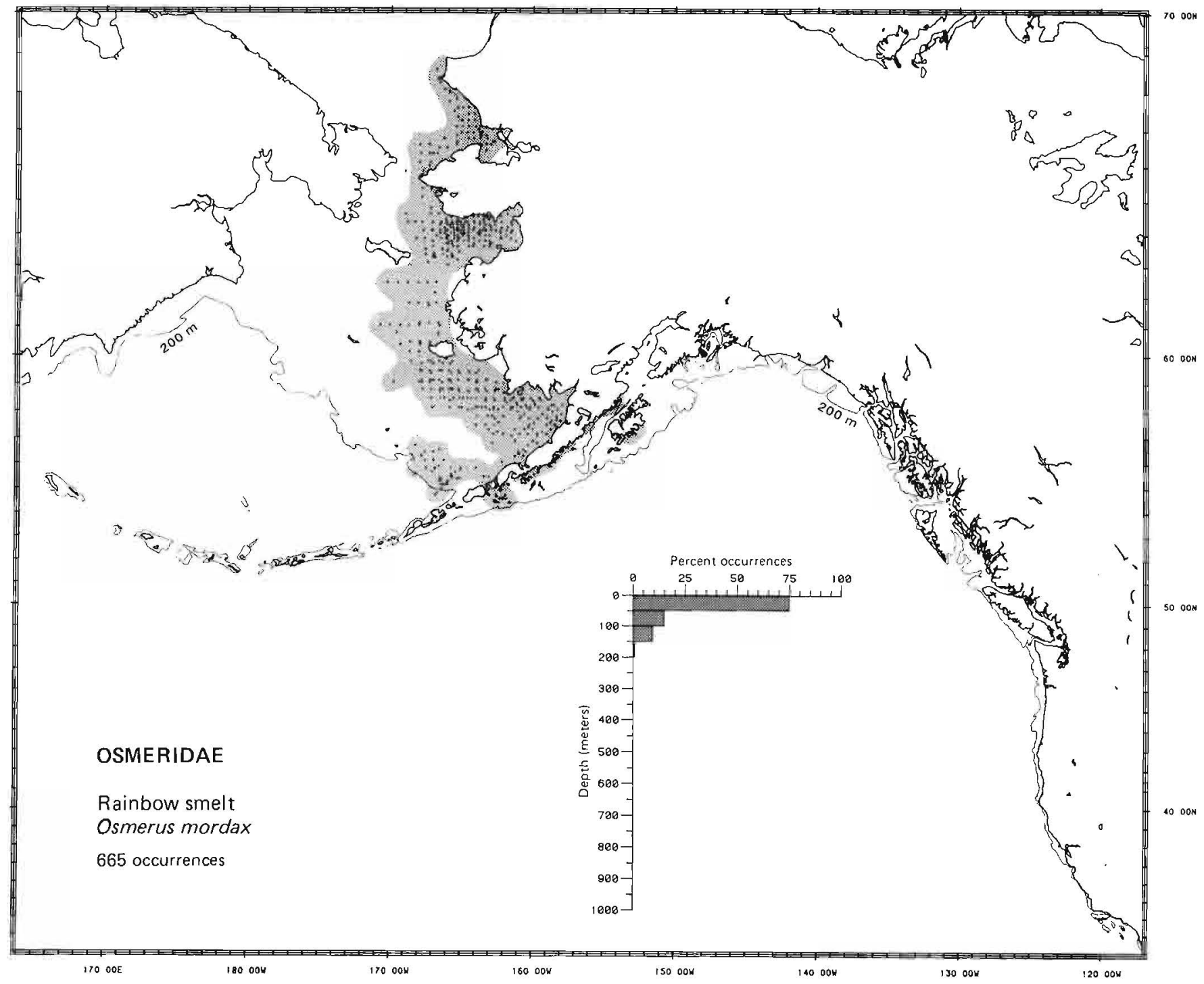


Literature Reported from the Pribilof Islands and Nushagak River, Alaska, in the Bering Sea and along the Aleutians south to Monterey Bay, California (Lee et al. 1980; Eschmeyer and Herald 1983). A pelagic and anadromous species, migrating up to $160 \mathrm{~km}$ upstream (Morrow 1980), and reported to $31 \mathrm{~m}$ in depth (Howe 1981).

Survey data Taken from west of Saint Matthew Island and off Kuskokwim Bay in the eastern Bering Sea to Bowers Bank in the Aleutian Islands and south to Monterey Bay, California. Depth range 25 to $625 \mathrm{~m}$, most frequently (44.7\% of occurrences) on the outer shelf between 100 and $150 \mathrm{~m}$, and $96.4 \%$ of occurrences from depths $\leqslant 300 \mathrm{~m}$. Survey data extend the northwestern limit of the known range along the Alaskan mainland, in the Bering Sea, and along the Aleutian Islands, and extend its maximum known depth by almost $600 \mathrm{~m}$. Because this species is pelagic, it may have been captured near the surface by trawls that were towed at greater depths; hence, the 625 -m maximum depth given here may greatly overestimate its true maximum depth.

\section{Conclusions}

Zoogeography Eastern boreal Pacific

Life zone Fluvial-oceanic (neritic)

Range From west of Saint Matthew Island and Kuskokwim Bay in the Bering Sea, and Bowers Bank in the Aleutian Islands to Monterey Bay, California, and to $160 \mathrm{~km}$ upstream

Depth Surface to about $300 \mathrm{~m}$, possibly $625 \mathrm{~m}$

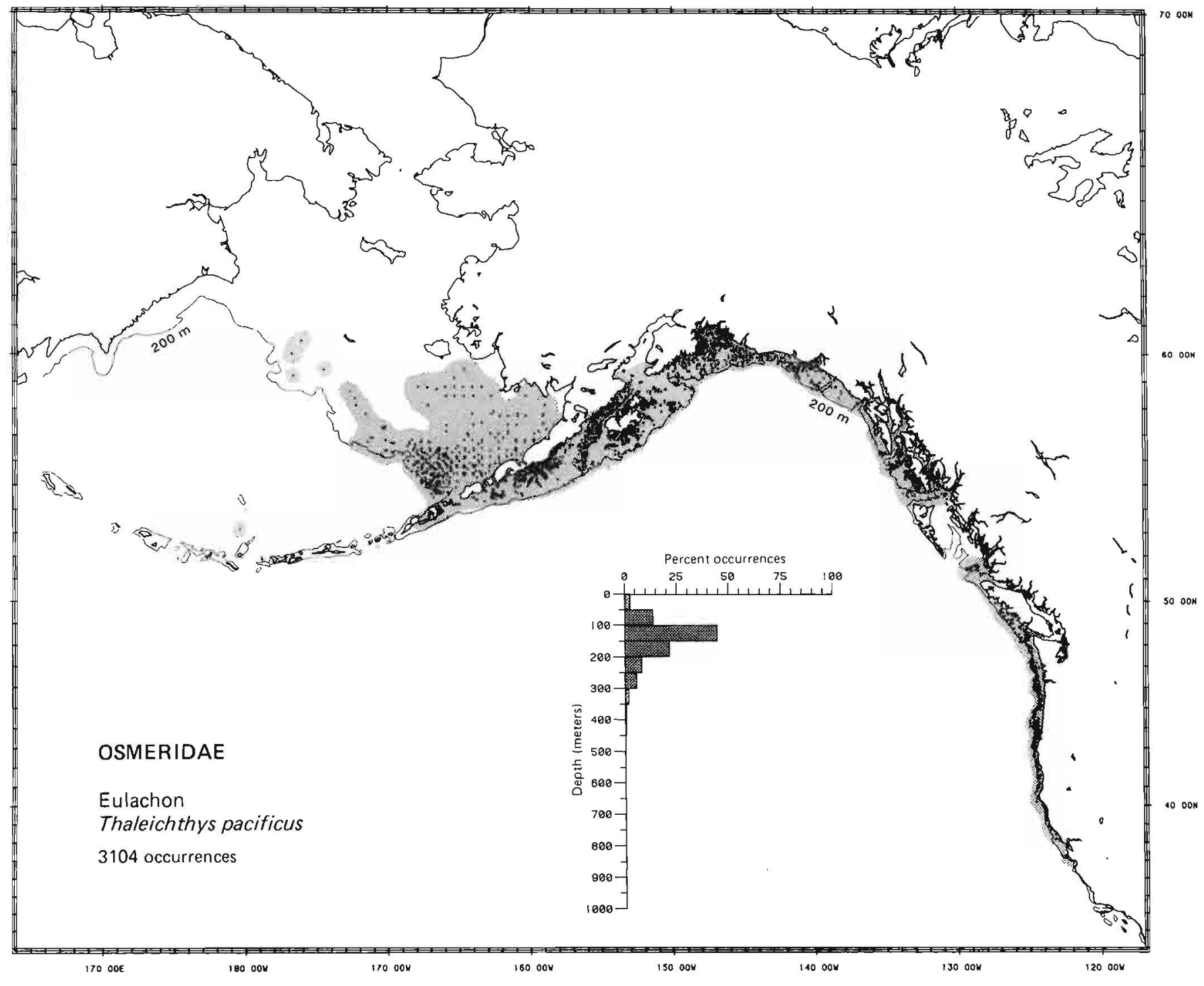


Literature Reported from the Arctic Ocean to northeastern Honshu, Japan, and San Diego, California (Fredin et al. 1977; Eschmeyer and Herald 1983). Range extends south in midocean to about lat. $40^{\circ} \mathrm{N}$ (Hubbs 1946; Hart 1973; Major et al. 1978), north to the Anadyr River in the western Bering Sea and east to the Coppermine River, Canada, in the Arctic (Hart 1973); also successfully introduced into New Zealand waters (Lee et al. 1980). Anadromous, migrating to $4827 \mathrm{~km}$ upstream (Browning 1980) and found to $200 \mathrm{~m}$ in depth in the ocean (Fedorov 1973a).

Survey data Found from Port Clarence, Alaska, Zhemchug Canyon on the eastern Bering Sea slope, and the Islands of the Four Mountains in the Aleutian Islands south to Santa Cruz, California. Depth range 25 to $375 \mathrm{~m}$, most frequently (24.7\% of occurrences) on the outer shelf between 100 and $150 \mathrm{~m}$, and $97.8 \%$ of occurrences from depths $<300 \mathrm{~m}$. Survey data are within known geographic range, but extend maximum known depth to $375 \mathrm{~m}$. Because this is a pelagic species generally found at depths of less than $128 \mathrm{~m}$ (Major et al. 1978), the fish were probably taken near the surface over deeper water.

\section{Conclusions}

Zoogeography Primarily Arctic-oceanic and northeastern boreal Pacific

Life zone Fluvial-oceanic (neritic)

Range From the Coppermine River in Arctic Canada to northeastern Honshu, Japan; also found from San Diego, California, and lat. $40^{\circ} \mathrm{N}$ in midocean, and introduced into New Zealand waters; migrates up to $4827 \mathrm{~km}$ upstream in rivers

Depth Surface to at least $200 \mathrm{~m}$, possibly up to $375 \mathrm{~m}$

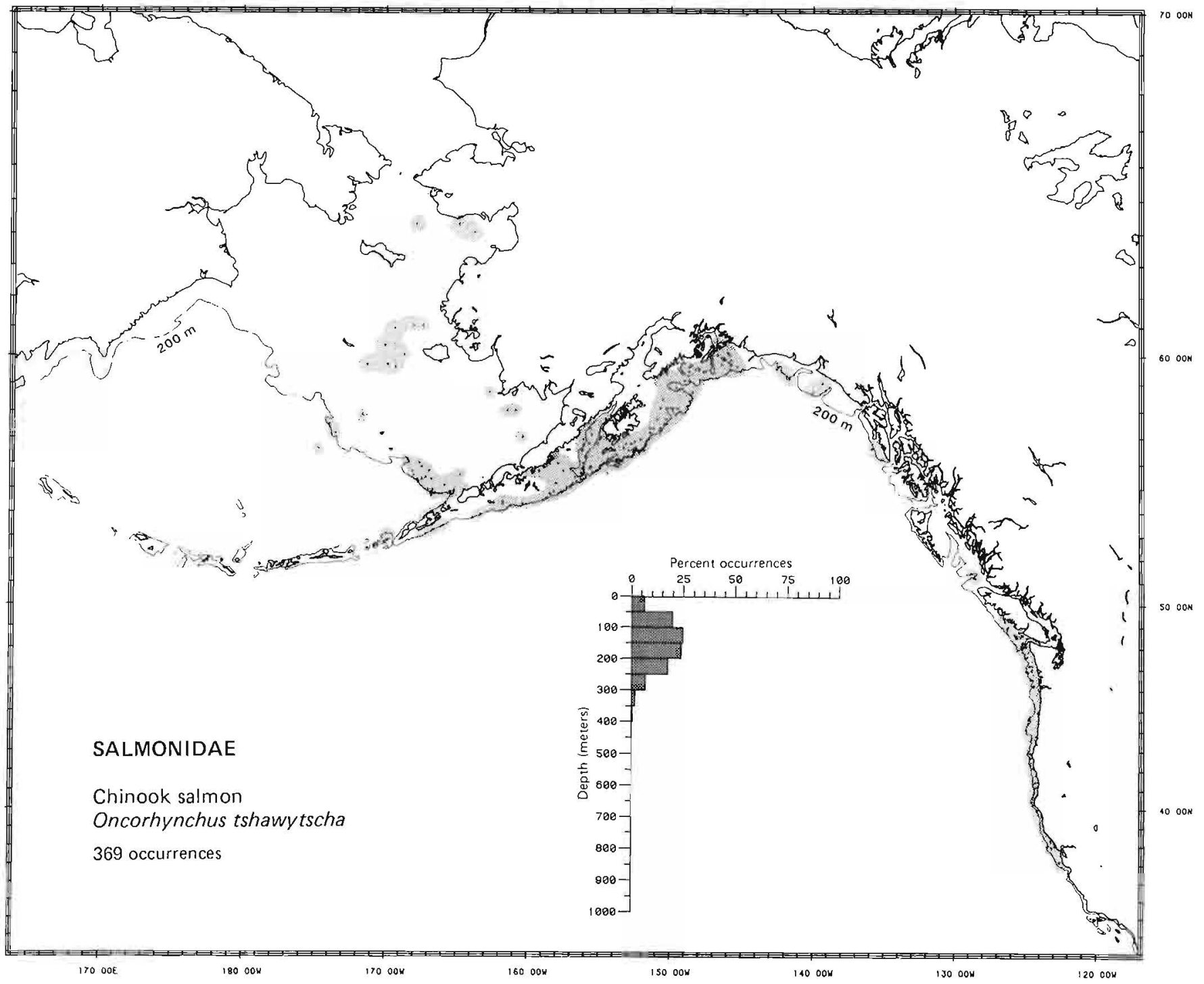


Literature A pelagic species that has been reported in the North Pacific, from the Bering Sea to Japan and central Baja California, and in the Gulf of California (Hart 1973; Howe 1981; Eschmeyer and Herald 1983). at 76 to $4231 \mathrm{~m}$ (Fedorov 1973a).

Survey data Found from Navarin Canyon on the northwest slope of the eastern Bering Sea and Agattu Island in the Aleutian Islands discontinuously to the Santa Barbara Channel, California. Depth range 25 to $975 \mathrm{~m}$, with $11.3 \%$ of occurrences above the bathybenthal slope between 550 and $600 \mathrm{~m}$, and $95.8 \%$ at depths $>250 \mathrm{~m}$. Survey data provide a more specific northern limit and a shallower depth limit. The Pacific viperfish is a mesopelagic species and hence was captured primarily along the slope. The distribution found in the survey data reflects that of demersal trawl tows rather than necessarily that of the species. Only a few mesopelagic midwater tows were taken over the Aleutian and North Pacific Basins.

\section{Conclusions}

Zoogeography Oceanic boreal Pacific

Life zone Mesopelagic

Range From Navarin Canyon in the Bering Sea to Japan, central Baja California, and the Gulf of California

Depth 25 to $4231 \mathrm{~m}$ (see note above)

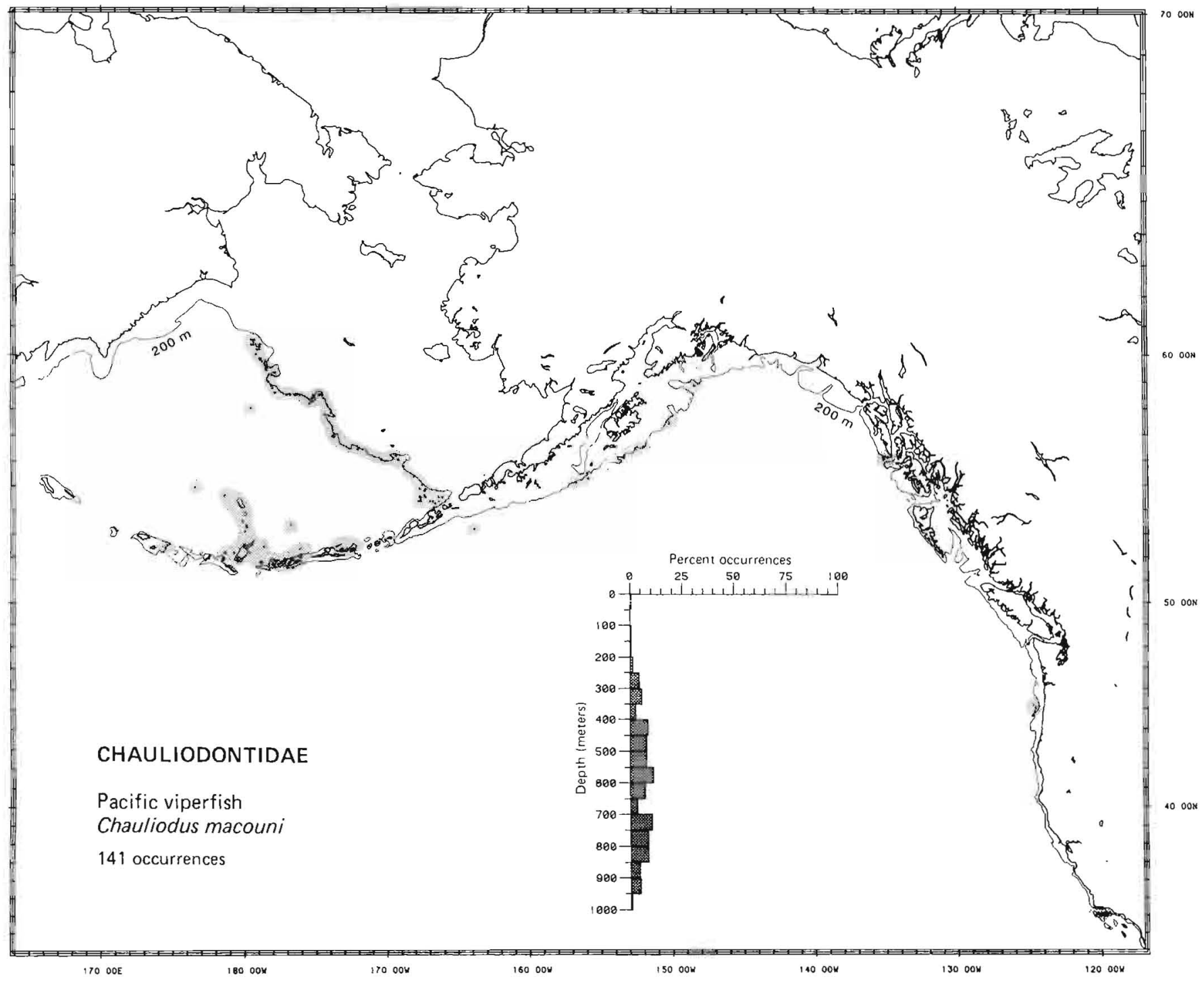


Taxonomic comment Although the giant grenadier is Coryphaenoides pectoralis in the most recent revision of the Macrouridae of the northeastern Pacific (i.e., Iwamoto and Stein 1974), it is placed in the genus Albatrossia in Eschmeyer and Herald (1983), based upon the present opinion of T. Iwamoto (Dep. Ichthyology, Calif. Acad. Sci., San Francisco, CA 94118, pers. commun. March 1986).

Literature Reported from northern Honshu, Japan, to the Bering Sea and south to northem Baja California (Quast and Hall 1972; T. Iwamoto, pers. commun. March 1986), at depths from 200 to $2189 \mathrm{~m}$ (Iwamoto and Stein 1974; Howe 1981).

Survey data Found from Navarin Canyon on the northwestern slope of the eastern Bering Sea and Stalemate Bank and the Ulm Plateau in the Aleutian Islands to Christian Sound, southeastern Alaska. Depth range 25 to $1025 \mathrm{~m}$, most frequently (13.6\% of occurrences) on the slope between 500 and $550 \mathrm{~m}$, and $94.9 \%$ of occurrences from depths of 300 to $900 \mathrm{~m}$. Although the survey data provide a new shallow record, it is clear that this species occurs primarily in deep water along the slope.

\section{Conclusions}

Zoogeography Northeastern boreal Pacific

Life zone Mesobenthal-bathybenthal (bathybenthal)

Range From northern Honshu, Japan, to Navarin Canyon in the Bering Sea and south to northern Baja California

Depth 200 to $2189 \mathrm{~m}$, although generally below $300 \mathrm{~m}$; possibly as shallow as $25 \mathrm{~m}$

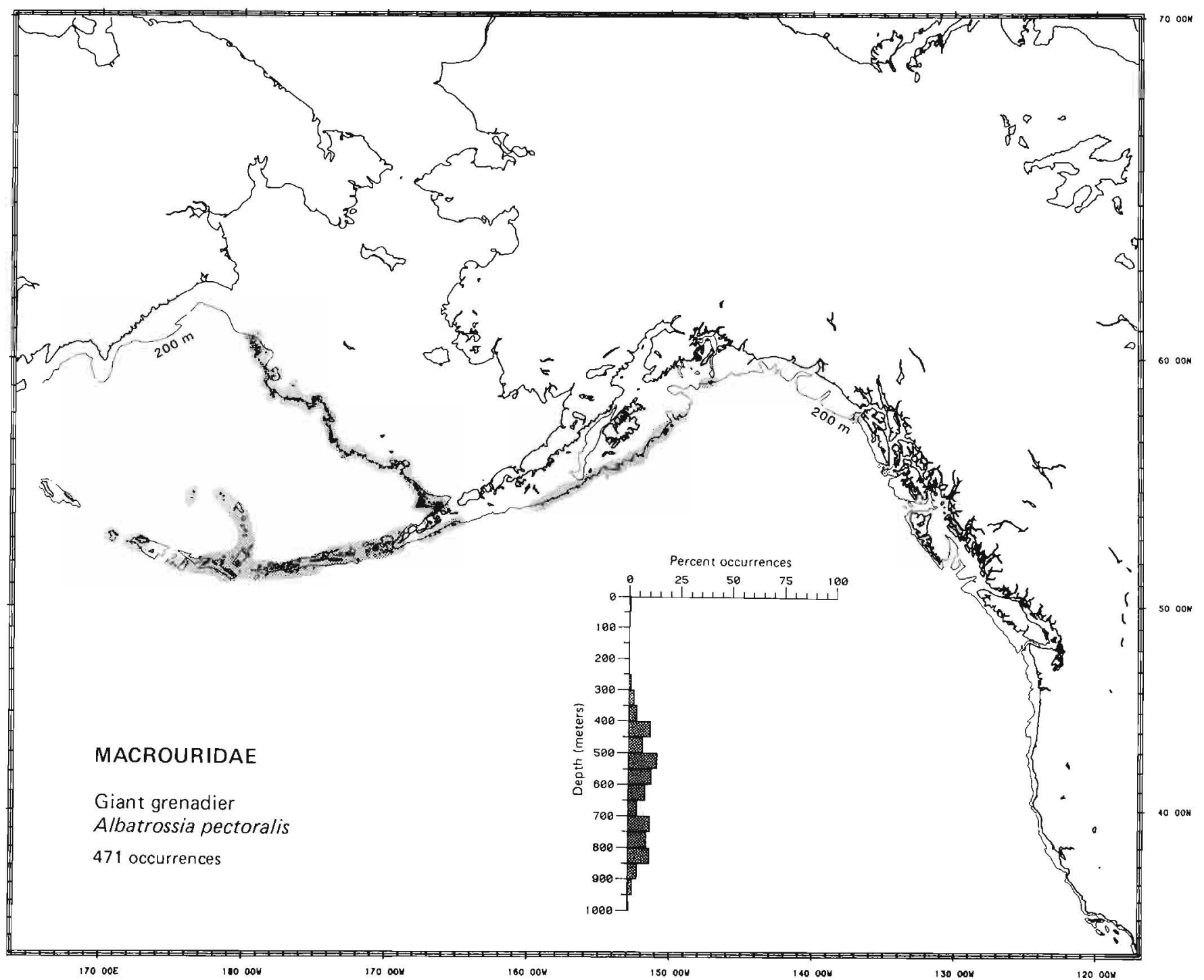


Literature Reported from northern Honshu, Japan, and the Sea of Okhotsk to the Bering Sea to Oregon (Iwamoto and Stein 1974; Howe 1981; T. Iwamoto, Dep. Ichthyology, Calif. Acad. Sci., San Francisco, CA 94118 , pers. commun. March 1986), at depths from 300 to 2832 m (Fedorov 1973a; Howe 1981).

Survey data Found from Navarin Canyon on the northwestern slope of the eastern Bering Sea and Stalemate Bank and the Ulm Plateau in the Aleutian Islands to Kodiak Island, Alaska. Depth range 225 to $1025 \mathrm{~m}$, most frequently ( $16.9 \%$ of occurrences) on the bathybenthal slope between 800 and $850 \mathrm{~m}$, and $97.8 \%$ of occurrences from depths of 400 to $950 \mathrm{~m}$. Survey data provide a more precise northermost limit in the Bering Sea and distribution in the Aleutian Islands, and a new shallow depth record.

\section{Conclusions}

Zoogeography Northeastern boreal Pacific

Life zone Mesobenthal-bathybenthal (bathybenthal)

Range From northern Honshu, Japan, and the Sea of Okhotsk to Navarin Canyon in the Bering Sea to Oregon

Depth 225 to $2832 \mathrm{~m}$

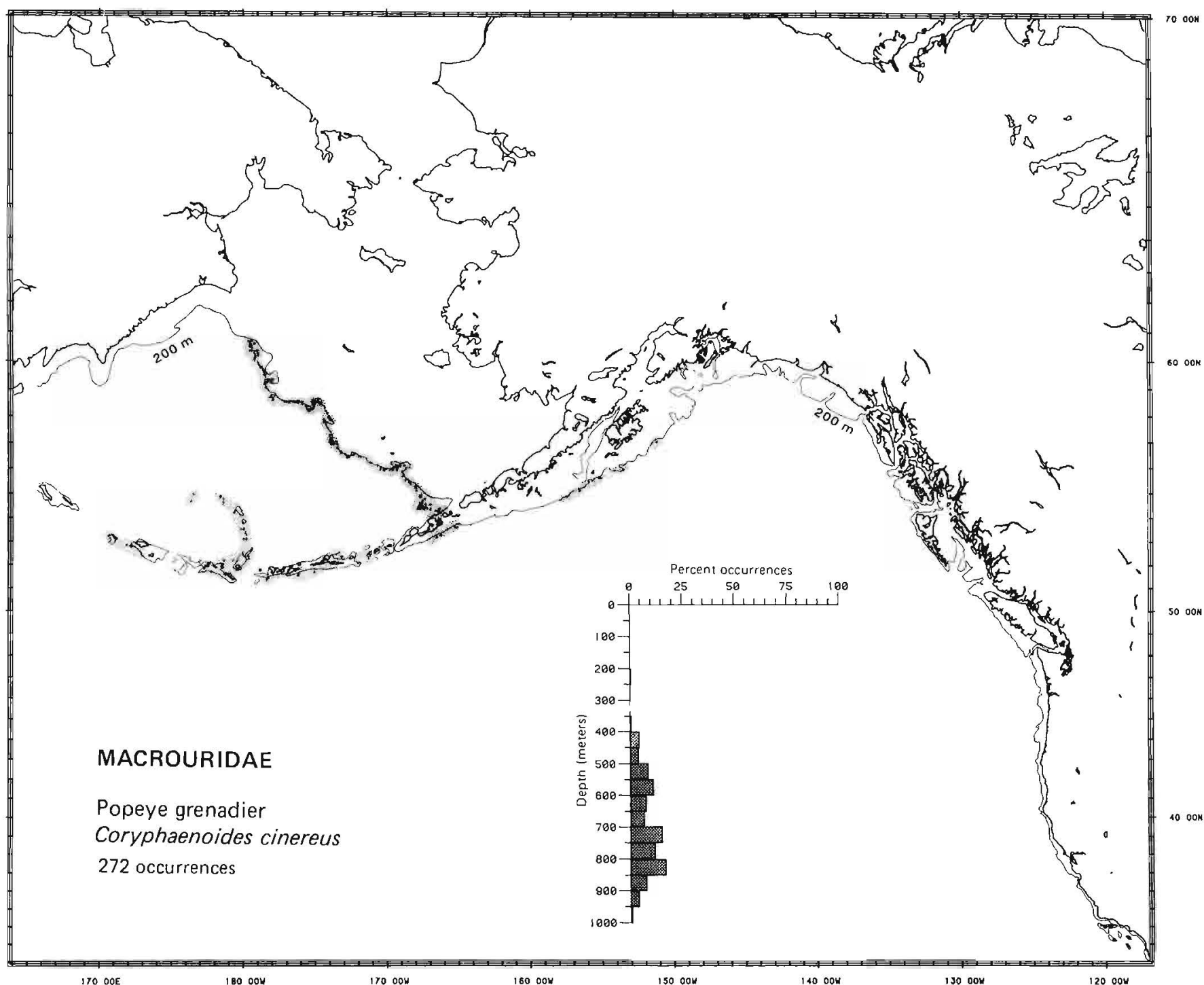


Literature A pelagic species reported from the Bering Sea to Magdalena Bay, Baja California Sur (Frey 1971; Fedorov 1973a; Eschmeyer and Herald 1983). Reports of its occurrence in the Gulf of California (Eschmeyer and Herald 1983) are in error (J. Arvizu, Centro Interdisciplinario de Ciencias Marinas, La Paz, Baja Calif. Sur, Mexico, pers. commun. October 1986). Miller and Lea (1972) and Eschmeyer and Herald (1983) noted that it occurred on the Asiatic coast, but Svetovidov (1948) had previously discounted this occurrence (at Dekastries Bay, U.S.S.R., in the Tatar Strait) as unlikely. Depths range from 0 to $914 \mathrm{~m}$, but generally occurs at depths $>229 \mathrm{~m}$ (Miller and Lea 1972; Howe 1981; Eschmeyer and Herald 1983).

Survey data Found from Sanak Island (southeast of Unimak Island in the Gulf of Alaska) to the Patton Escarpment off southern California. Depth range 25 to $575 \mathrm{~m}$, with $28.6 \%$ of occurrences on the outer shelf between 100 and $150 \mathrm{~m}$, and $97.9 \%$ of occurrences from depths between 50 and $500 \mathrm{~m}$.

\section{Conclusions}

$\begin{array}{ll}\text { Zoogeography } & \text { Eastern temperate Pacific } \\ \text { Life zone } & \text { Neritic-mesopelagic (neritic) } \\ \text { Range } & \text { From the Bering Sea to Magdalena Bay, Baja California Sur } \\ \text { Depth } & 0 \text { to } 914 \mathrm{~m}\end{array}$

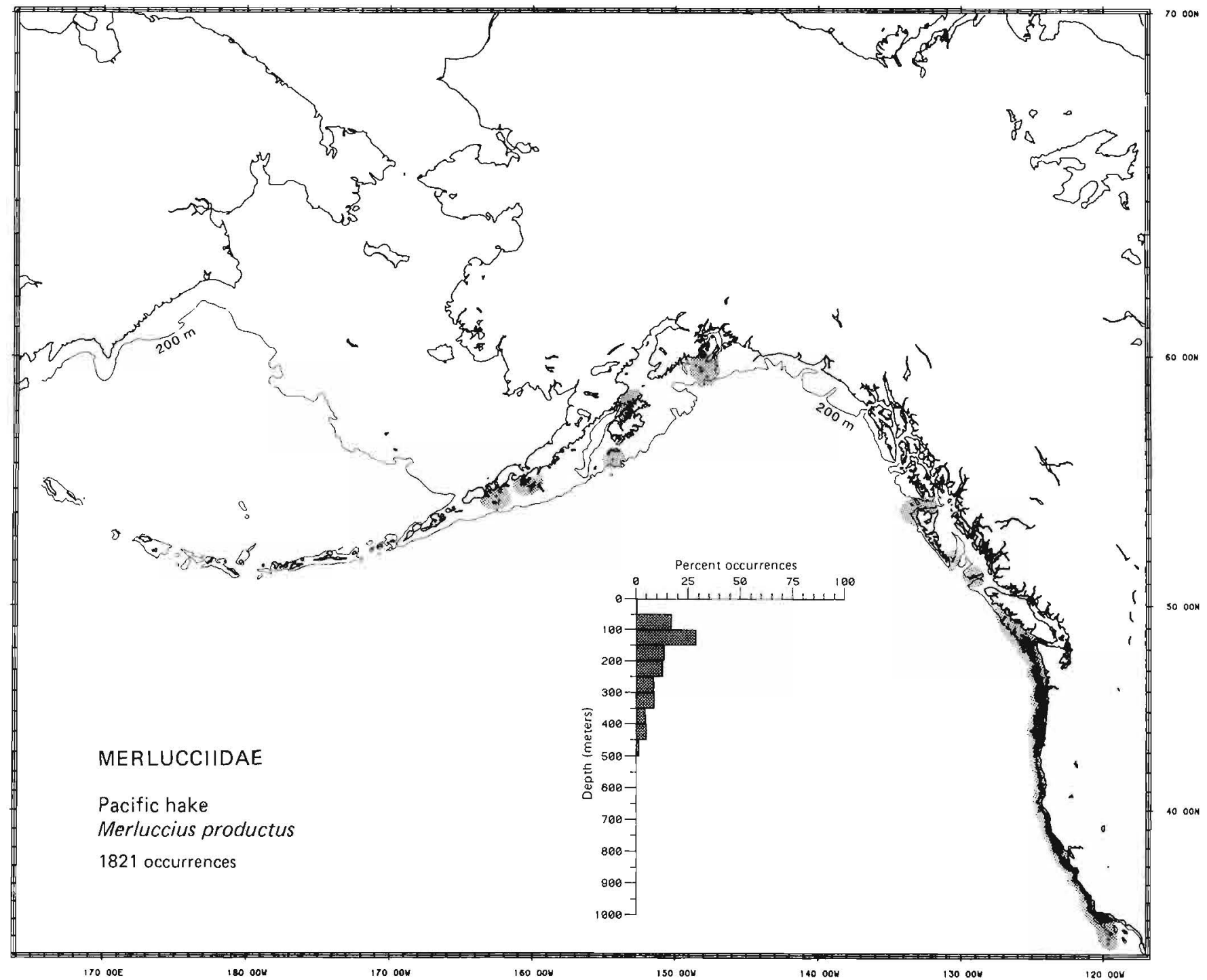


Literature Circumpolar in the Arctic Ocean and reported from near the North Pole to Cape Olyutorski and Norton Sound in the Bering Sea and to the Miramichi River, New Brunswick, the southern tip of Greenland, northern Iceland, and the White Sea in the Atlantic and European Arctic (McKenzie 1953; Andriyashev 1954; Quast and Hall 1972; Muus 1974). A pelagic species found upstream in rivers and, in the ocean, to $731 \mathrm{~m}$ (Leim and Scott 1966; Morrow 1980) in depth.

Survey data Found from northeast of Cape Lisburne in the Chukchi Sea south in the eastern Bering Sea to Cape Navarin, the Pribilof Islands, and Bristol Bay. Depth range 25 to $175 \mathrm{~m}$, with $46.1 \%$ of occurrences on the inner shelf between 0 and $50 \mathrm{~m}$, and $99.6 \%$ from depths $<150 \mathrm{~m}$. Survey data extend the southernmost limit of the known range in the eastern Bering Sea to the Pribilof Islands and Bristol Bay.

\section{Conclusions}

$\begin{array}{ll}\text { Zoogeography } & \text { Arctic } \\ \text { Life zone } & \text { Neritic-epipelagic (neritic) } \\ \text { Range } & \text { Throughout the Arctic to the White Sea, Iceland, and southern Greenland, in the western Atlantic into the Miramichi } \\ & \text { River, New Brunswick, and in the Bering Sea to Cape Olyutorski, the Pribilof Islands, and Bristol Bay } \\ \text { Depth } & \text { Surface to } 731 \mathrm{~m}\end{array}$

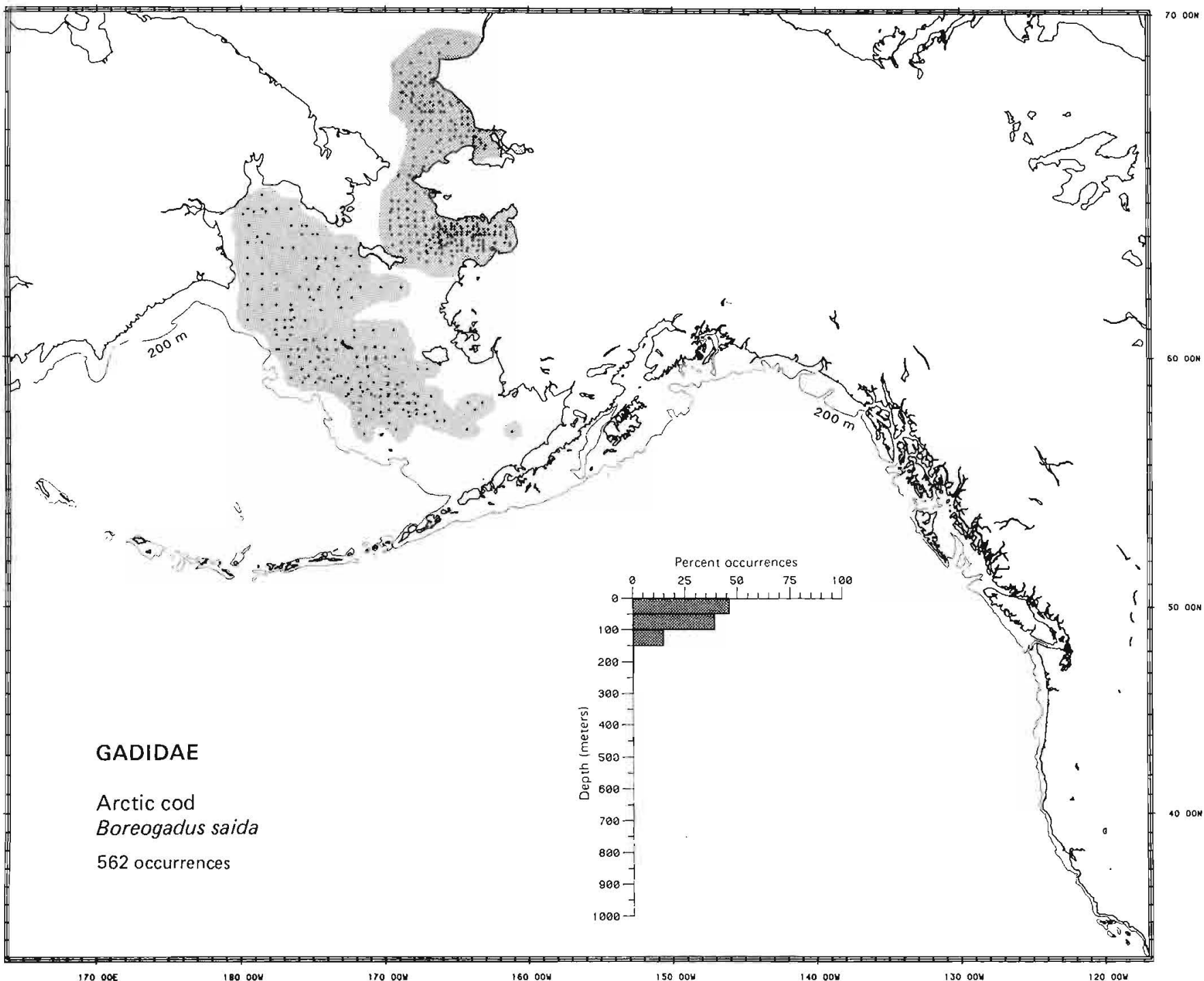


Literature Reported from Chemulpo, North Korea, in the Yellow Sea to Kotzebue Sound in the Chukchi Sea; south in the Aleutian Islands to Unalaska Island; and east to Sitka, Alaska (Svetovidov 1948; Andriyashev 1954; Wilimovsky 1964). Found at least $10 \mathrm{~km}$ up rivers (but within tidal influence) and to $60 \mathrm{~m}$ deep in the ocean (Svetovidov 1948; Howe 1981).

Survey data Found from Cape Olyutorski in the western Bering Sea and from southern Bristol Bay in the eastern Bering Sea to Cape Lisburne in the Chukchi Sea. Depth range 25 to $75 \mathrm{~m}$, most frequently ( $88.9 \%$ of occurrences) on the inner shelf at depths $<50 \mathrm{~m}$ and occurred only at depths $<75 \mathrm{~m}$. Survey data extend known range slightly to the north and provide a new maximum depth record. The species has seldom been taken in the Gulf of Alaska.

\section{Conclusions}

Zoogeography Arctic-northwestern boreal Pacific

Life zone Inner shelf

Range From Cape Lisburne in the Chukchi Sea to Chemulpo, North Korea, in the Yellow Sea and Sitka, Alaska

Depth Surface to $75 \mathrm{~m}$

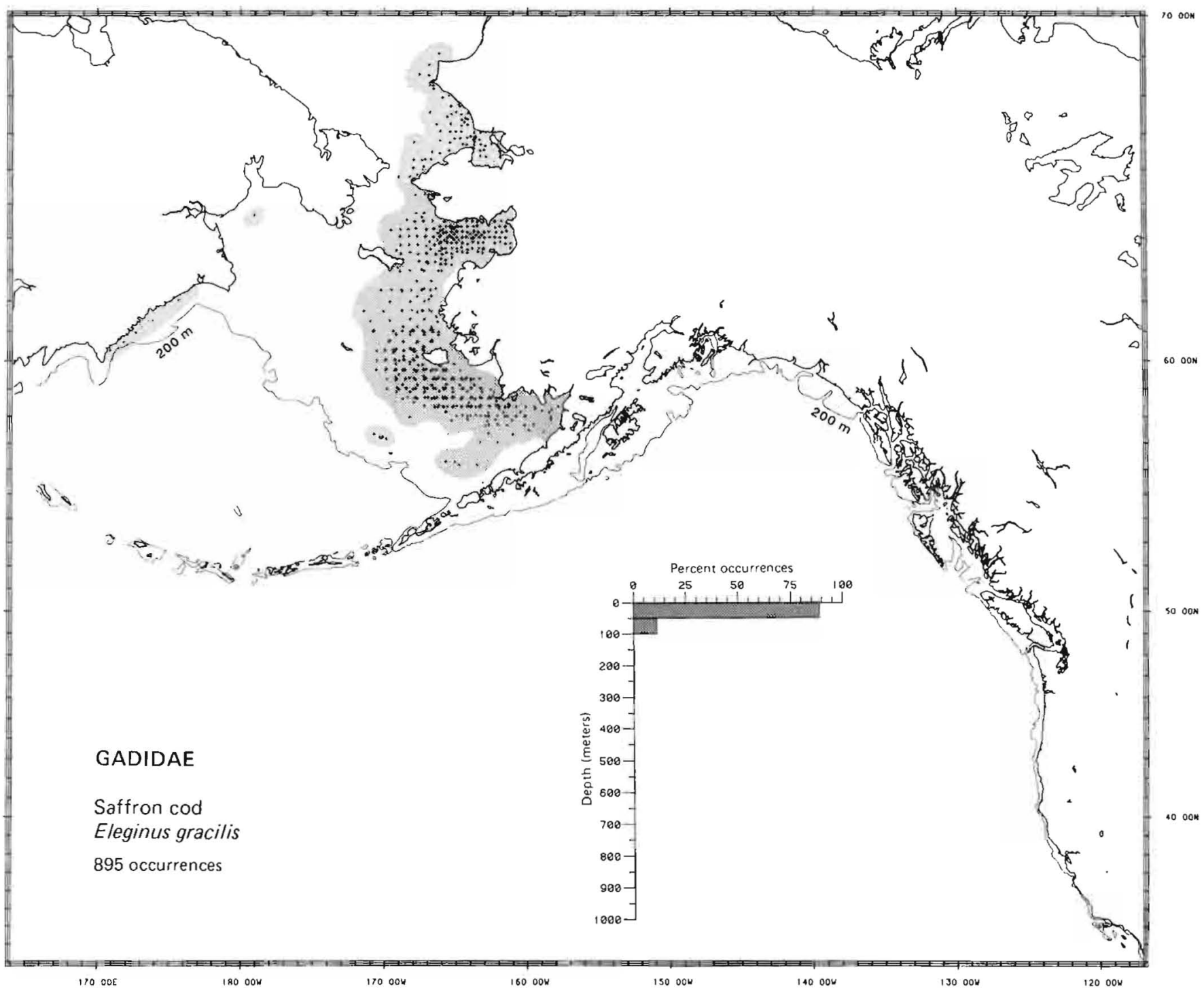


Literature Reported from Lushun (Port Arthur), Manchuria, China, in the Yellow Sea to the Bering Strait, along the Commander and Aleutian Islands, and from there to Santa Monica, California (Andriyashev 1954; Okada and Kobayashi 1968; Hart 1973; Eschmeyer and Herald 1983), at 0 to $675 \mathrm{~m}$ in depth (Fedorov 1973a; Howe 1981).

Survey data Found from Cape Olyutorski and Medny Seamount in the western Bering Sea to off Cape Rodney in the northern Bering Sea, throughout the eastern Bering Sea, along the Aleutian Islands to Attu Island, and from the Alaska Peninsula to Cape Mendocino, California. Depth range 25 to $875 \mathrm{~m}$, most frequently ( $32.4 \%$ of occurrences) on the outer shelf from 100 to $150 \mathrm{~m}$, and $97.8 \%$ of occurrences from depths $<300 \mathrm{~m}$. Survey data provide a new maximum depth record.

\section{Conclusions}

Zoogeography Circumboreal Pacific

Life zone Inner shelf-mesobenthal (outer shelf)

Range From Lushun, Manchuria, China, to the Bering Strait, along the Commander and Aleutian Islands, and from there

Depth $\quad 0$ to $875 \mathrm{~m}$

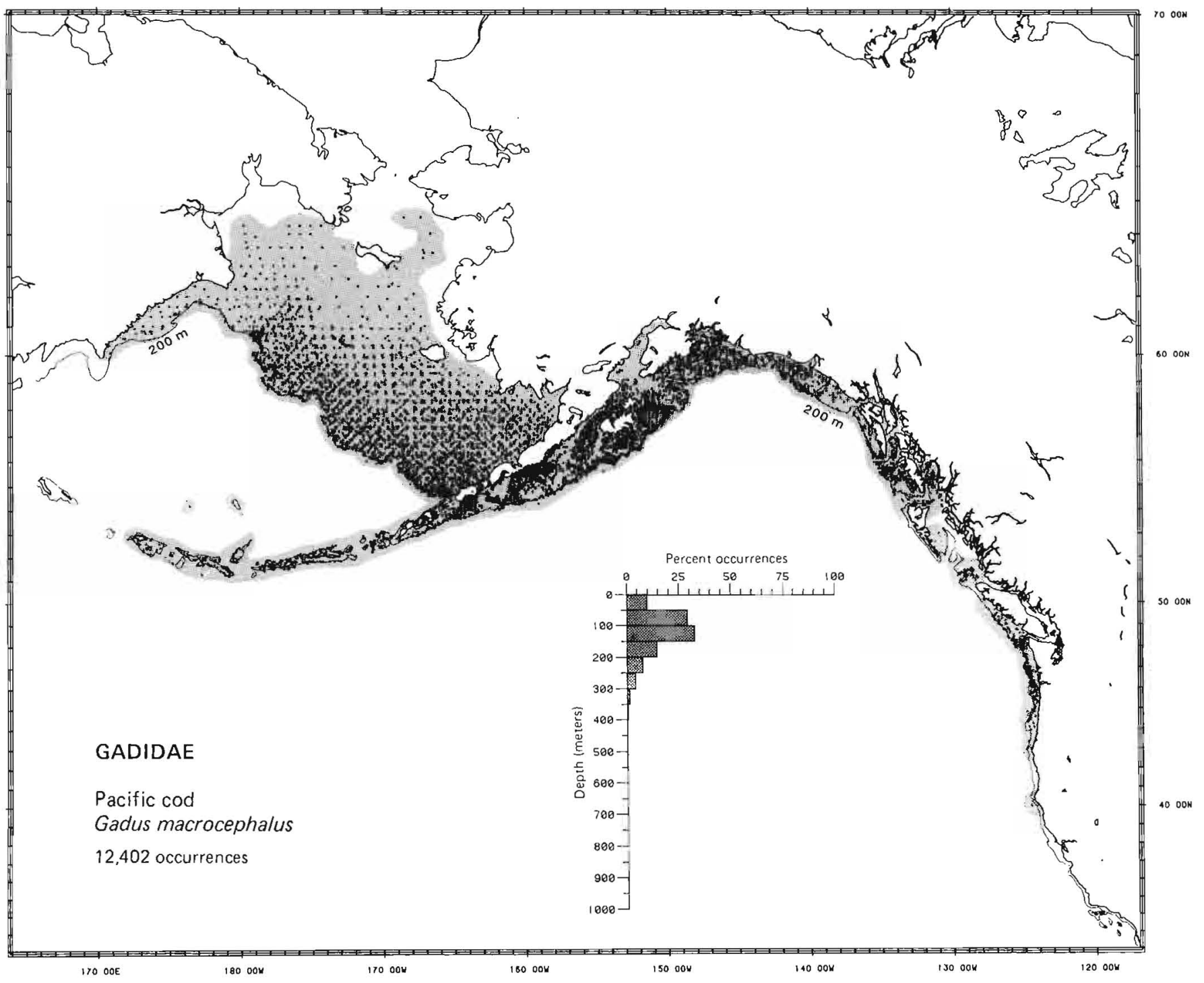


Literature Reported from the Bering Sea and Unalaska Island to Point Sal, California (Miller and Lea 1972; Hart 1973). Occurs in estuaries to the Mesohaline Zone and has been taken from 0 to $260 \mathrm{~m}$ in depth (Hart 1973; Eschmeyer and Herald 1983; Simenstad 1983).

Survey data Found from off Kuskokwim Bay and the Pribilof Islands in the southeastern Bering Sea and Unalaska Island in the Aleutian Islands to Monterey Bay, California. Depth range 25 to $275 \mathrm{~m}$, most frequently (51.5\% of occurrences) on the middle shelf between 50 and $100 \mathrm{~m}$, and $96.8 \%$ of occurrences from depths $<150 \mathrm{~m}$. Survey data provide a slightly greater maximum depth and better define the distribution of the species in the Bering Sea. However, some records in the southeastern Bering Sea may actually be of the morphologically-similar saffron cod, Eleginus gracilis (J. R. Dunn, Northwest Alaska Fish., Cent., Natl. Mar. Fish. Serv., NOAA, Seattle, WA 98115 , pers. commun. March 1986).

\section{Conclusions}

Zoogeography Eastern boreal Pacific

Life zone Inner shelf-outer shelf (middle shelf)

Range From Kuskokwim Bay, the Pribilof Islands, and Unalaska Island in the Bering Sea to Point Sal, California Depth $\quad 0$ to $275 \mathrm{~m}$

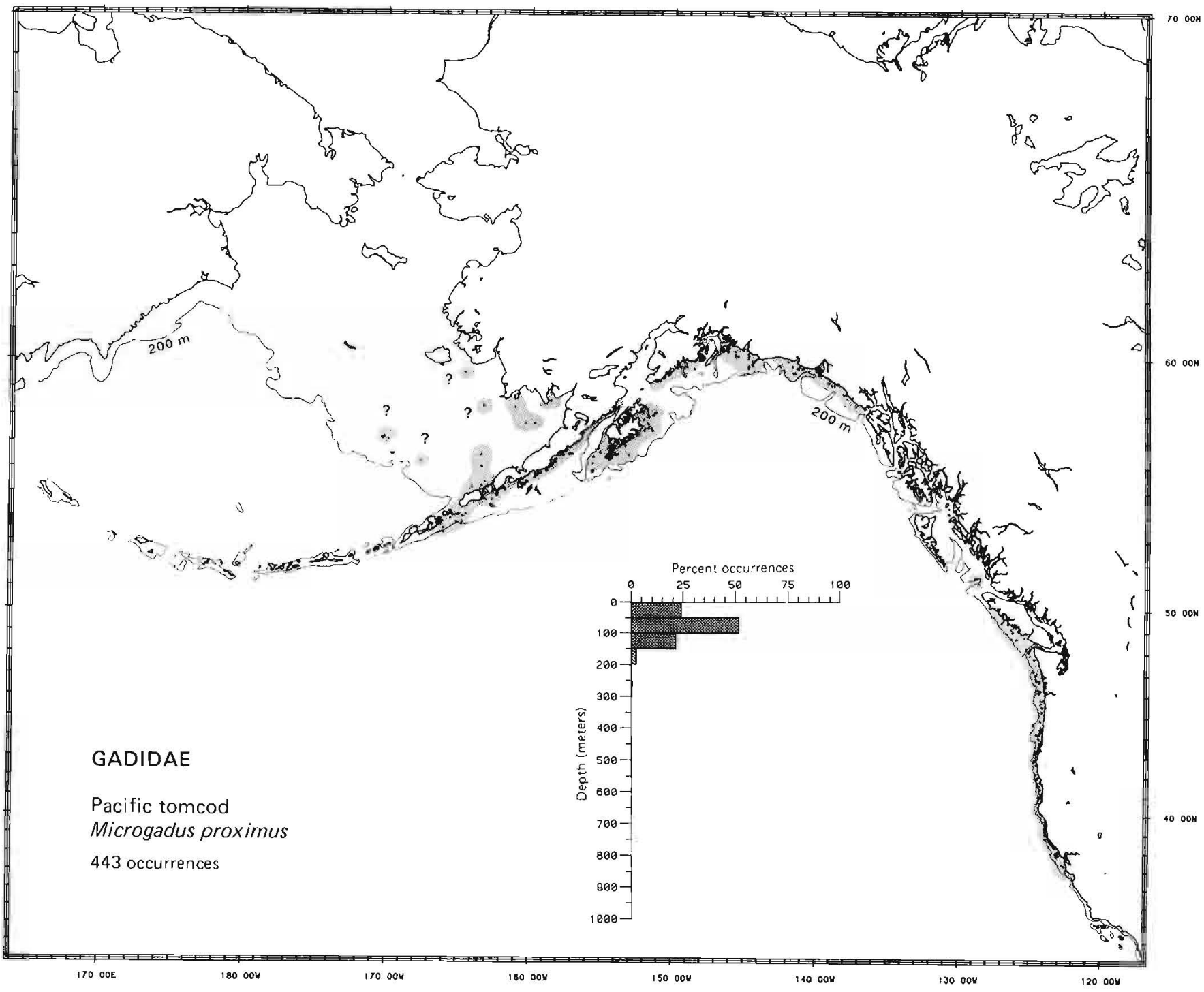


Literature Reported from the southern Sea of Japan to the Chukchi Sea, along the Aleutian Islands to Amchitka Island and south to Carmel, California (Wilimovsky 1964; Hart 1973; Wolotira et al. 1977), from 0 to $750 \mathrm{~m}$ (Hart 1973; Fedorov 1973a). The occurrence of this species off northern Baja California given in Quast and Hall (1972) is apparently an error.

Survey data Found from Bering Island in the western Bering Sea to Kivalina, Alaska, in the Chukchi Sea, south throughout the Bering Sea, Aleutian Basin, and Aleutian Islands to Cape Blanco, Oregon, and in midwater hauls from across the Aleutian Basin. Depth range 25 to $975 \mathrm{~m}$, most frequently (32.3\% of occurrences) on the outer shelf between 100 and $150 \mathrm{~m}$, and $94.8 \%$ of occurrences from depths $<300 \mathrm{~m}$. Survey data provide a new northernmost limit and extend the maximum known depth by $225 \mathrm{~m}$. Midwater distribution across the Aleutian Basin indicates the species is pelagic.

\section{Conclusions}

Zoogeography Arctic-circumboreal Pacific

Life zone Neritic-mesopelagic (neritic)

Range From Kivalina, Alaska (new northernmost limit), in the Chukchi Sea to the southern Sea of Japan and to Carmel, California Depth

$$
0 \text { to } 975 \mathrm{~m}
$$

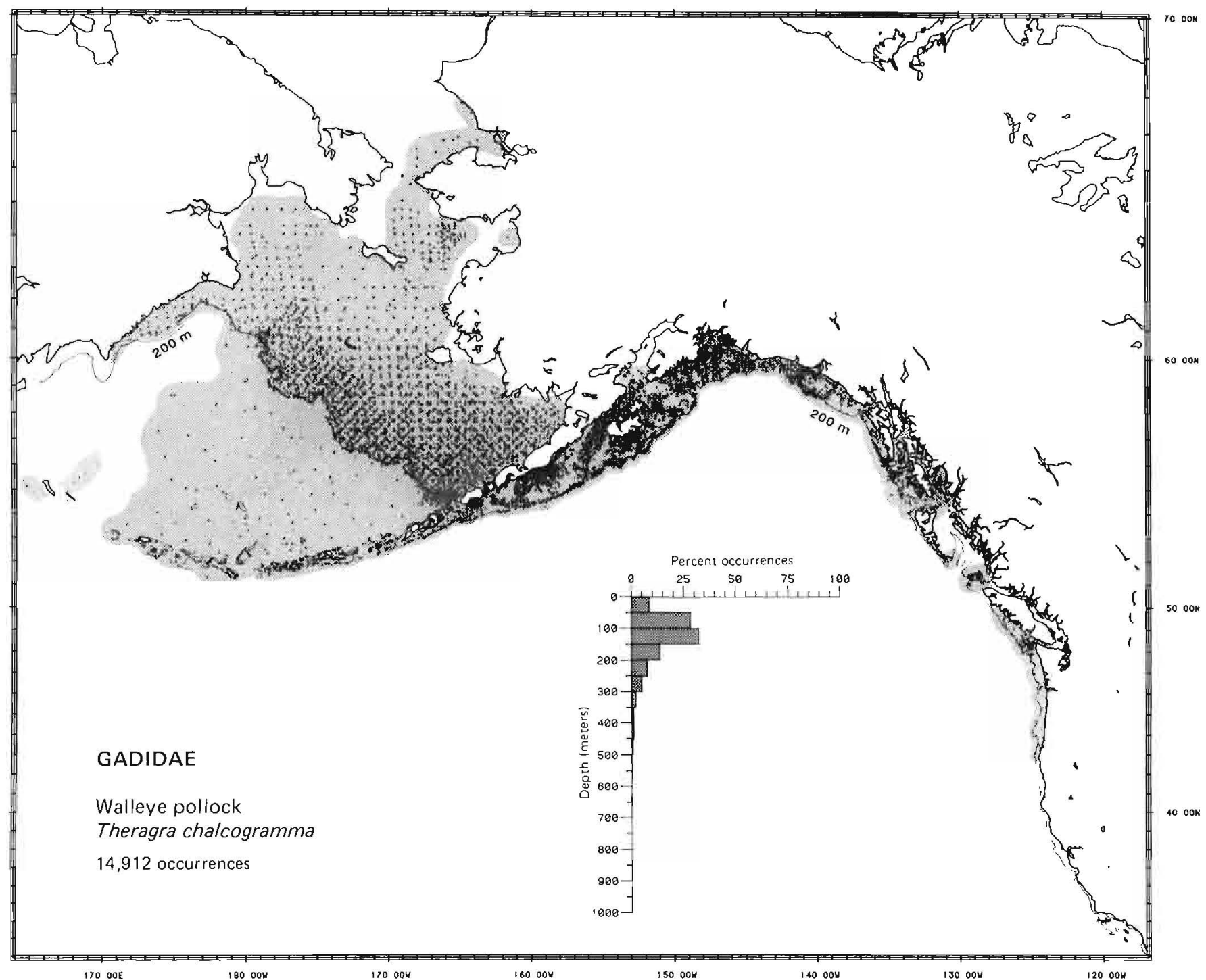


Literature Reported from Shikoku Island, Japan, north to the southeastern Bering Sea, southeast to the Gulf of California, and off Johnston Island in the central North Pacific. Probably occurs throughout the Pacific north of lat. $10^{\circ} \mathrm{N}$ (Small 1981). Depth range from 363 to $3048 \mathrm{~m}$ (Miller and Lea 1972; Howe 1981).

Survey data Found from Navarin Canyon in the Bering Sea along the southeastern rim of the Aleutian Basin to Attu Island (including Bowers Bank) and discontinuously along the rim of the northeastern Pacific Basin to Point Reyes, California. Depth range 25 to $1275 \mathrm{~m}$, most frequently ( $18.9 \%$ of occurrences) on the bathybenthal slope between 800 and $850 \mathrm{~m}$, and $96.4 \%$ of occurrences at depths $>350 \mathrm{~m}$. Survey data define a northern limit in the Bering Sea and more completely defines distribution along the Aleutian Islands. The shallow occurrence of this species in Bristol Bay must be regarded as questionable; the next shallowest occurrence was at $175 \mathrm{~m}$.

\section{Conclusions}

Zoogeography Temperate north Pacific

Life zone Mesobenthal-bathybenthal

Range From Shikoku Island, Japan, to Navarin Canyon in the Bering Sea, the Gulf of California, and Johnston Island

Depth About $175 \mathrm{~m}$ (possibly $25 \mathrm{~m}$ ) to $3048 \mathrm{~m}$

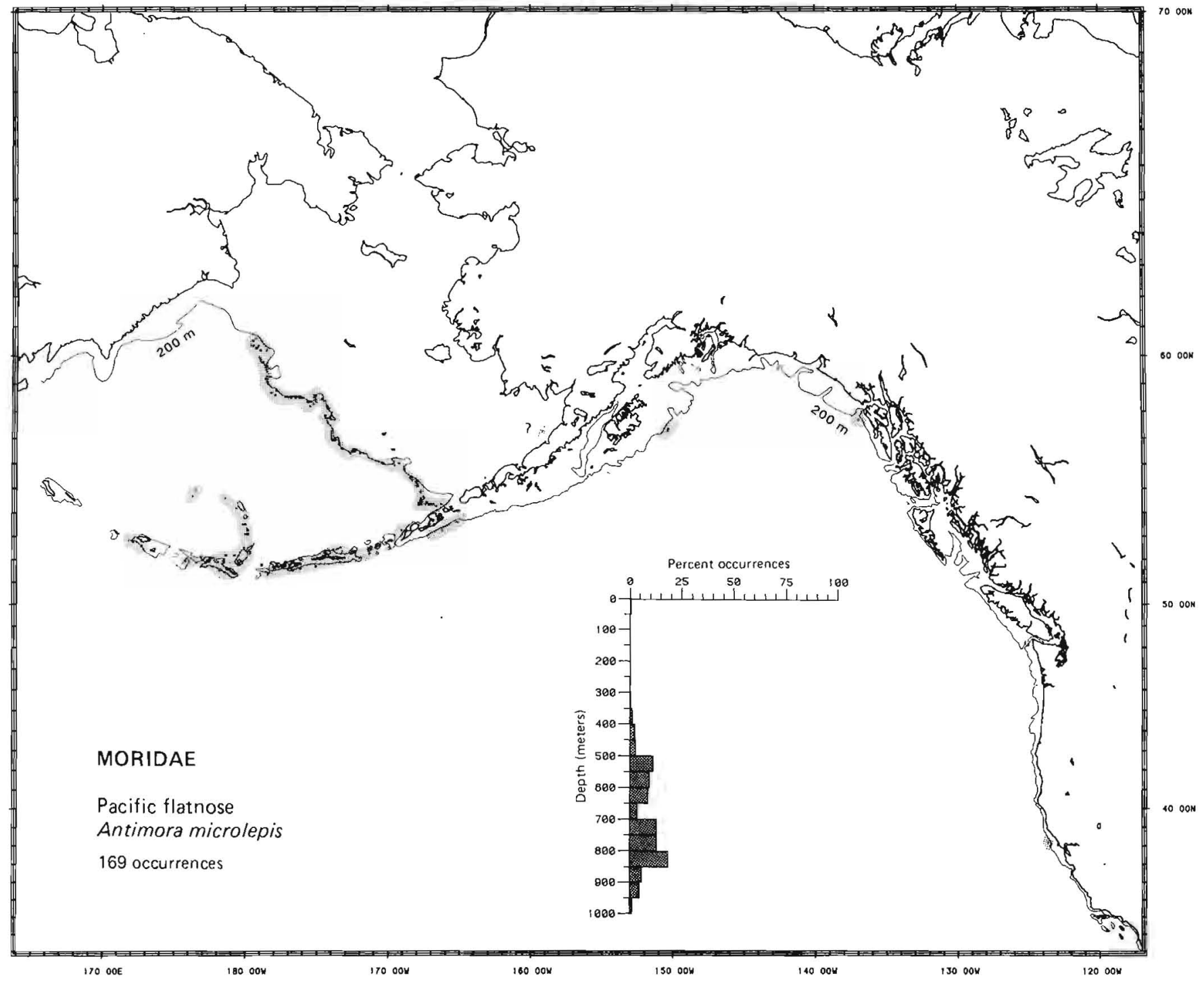


Literature Taken from Sitka, Alaska, to Magdalena Bay, Baja California Sur. Previous records south of there and in the Gulf of California are in error (Miller and Lea 1972; H. J. Walker, Scripps Inst. Oceanogr., Univ. Calif., San Diego, La Jolla, CA 92093, pers. commun. December 1986). Depth range reported from intertidal zone to $366 \mathrm{~m}$ (Hart 1973; Eschmeyer and Herald 1983). Commonly occurs intertidally during spawning season (at least north of Point Conception, California; Ibara 1967).

Survey data Found from Barkley Sound, Vancouver Island, British Columbia, to Santa Monica Bay, California. Depth range 25 to $275 \mathrm{~m}$, most frequently (49.7\% of occurrences) on the outer shelf between 100 and 150 , m and $96.6 \%$ of occurrences from depths of 50 to $250 \mathrm{~m}$. Survey data lie within the known geographic and depth ranges, but give a more precise depth of common occurrence.

\section{Conclusions}

Zoogeography Oregonian-Californian

Life zone Intertidal-mesobenthal (outer shelf)

Range From Sitka, Alaska, to Magdalena Bay, Baja California Sur

Depth Intertidal zone to $366 \mathrm{~m}$

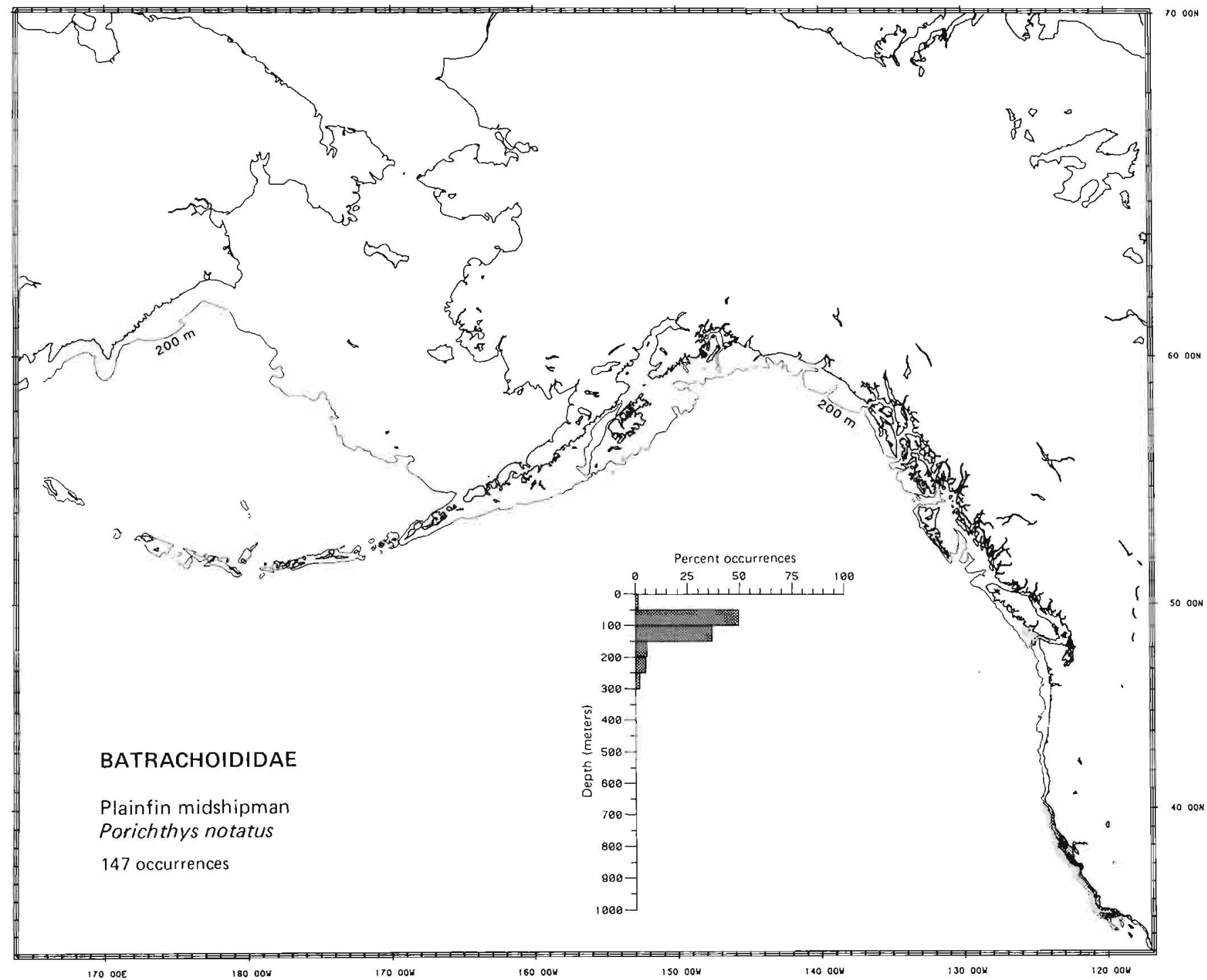


Literature Reported from Japan to the Bering Sea (but not in the Sea of Okhotsk), west in the Aleutian Islands to Amchitka Island, and south to San Diego, California (Miller and Lea 1972; Simenstad et al. 1977; Howe 1981; Eschmeyer and Herald 1983). Reported depths from 88 to $732 \mathrm{~m}$ (deeper records to $2820 \mathrm{~m}$ were probably shortraker rockfish, Sebastes borealis; Fedorov 1973a; Hart 1973).

Survey data Found from Navarin Canyon on the northwestern slope of the eastern Bering Sea and Stalemate Bank and the UIm Plateau in the Aleutian Islands to Point Sal, California. Depth range 25 to $875 \mathrm{~m}$, most frequently (19.0\% of occurrences) on the mesobenthal slope between 250 and $300 \mathrm{~m}$, and $95.4 \%$ of occurrences from 50 to $450 \mathrm{~m}$. Survey data provide a more precise description of the northernmost limit, distribution in the Aleutian Islands, and new depth limits.

\section{Conclusions}

Zoogeography Eastern boreal Pacific

Life zone Middle shelf-mesobenthal (mesobenthal)

Range From Japan to Navarin Canyon in the Bering Sea (but not in the Sea of Okhotsk), throughout the Aleutian Islands, and south to San Diego, California

Depth $\quad 25$ to $875 \mathrm{~m}$

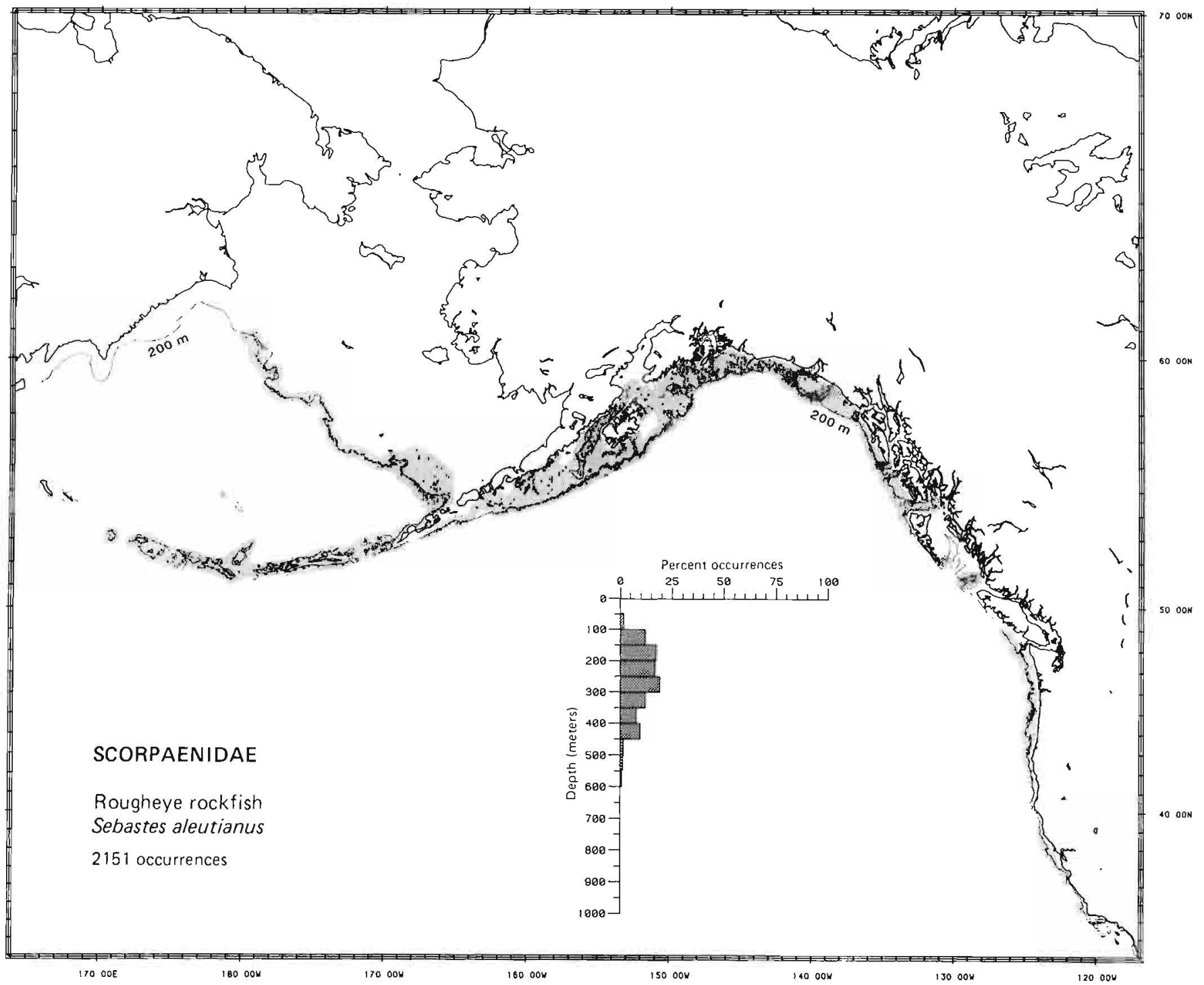


Literature Reported from north of Honshu, Japan, to Cape Olyutorski in the Bering Sea (but not in the Sea of Okhotsk), Attu Island in the Aleutians, and south to La Jolla, California (Shmidt 1950; Wilimovksy 1964; Quast and Hall 1972; Hart 1973; Eschmeyer and Herald 1983), at depths of 0 to $800 \mathrm{~m}$, but generally at depths $>128 \mathrm{~m}$ (Hart 1973; Howe 1981).

Survey data Found from off Glubokaya Bay on the Korak Coast in the western Bering Sea to south of Cape Navarin in the northern Bering Sea, along the slope of the eastern Bering Sea to Unimak Island (including Medny Seamount off the Commander Islands) and from Stalemate Bank and the Ulm Plateau in the Aleutian Islands southeast to Oxnard, California. Depth range 25 to $825 \mathrm{~m}$, most frequently ( $24.6 \%$ of occurrences) on the outer shelf between 150 and $200 \mathrm{~m}$, and $96.8 \%$ of occurrences from 100 to $450 \mathrm{~m}$. Survey data provide a new northern limit for the Pacific ocean perch, as well as a more precise description of its distribution in the Aleutian Islands and a slightly greater maximum depth record.

\section{Conclusions}

Zoogeography Kurile-Aleutian

Life zone Outer shelf-mesobenthal (outer shelf)

Range From Honshu, Japan, to Cape Navarin in the Bering Sea (but not in the Sea of Okhotsk) and La Jolla, California, Depth $\quad 0$ to $825 \mathrm{~m}$

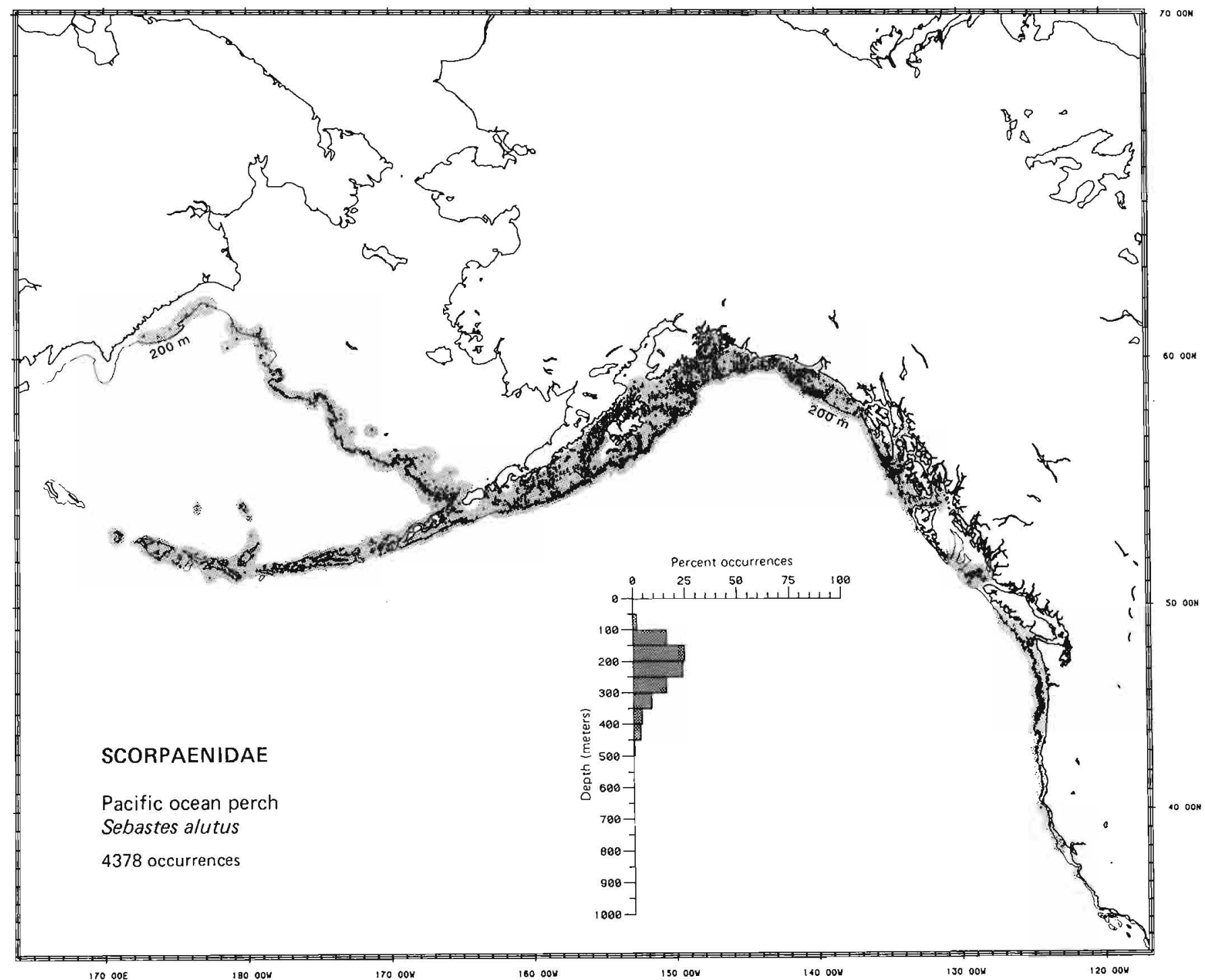


Literature Reported from Amphitrite Point on Vancouver Island, British Columbia, to Cedros Island, Baja California (Miller and Lea 1972), at depths of 183 to $768 \mathrm{~m}$ (Eschmeyer and Herald 1983).

Survey data Found from Cape Flattery, Washington, to the Patton Escarpment off southern California. Depth range 125 to $575 \mathrm{~m}$, most frequently ( $45.8 \%$ of occurrences) on the mesobenthal slope from 400 to $450 \mathrm{~m}$, and $95.8 \%$ of occurrences from depths of 150 to $500 \mathrm{~m}$. Survey data provide a new shallow depth limit.

\section{Conclusions}

Zoogeography Oregonian-San Diegan

Life zone Outer shelf-mesobenthal (mesobenthal)

Range From Amphitrite Point, Vancouver Island, to Cedros Island, Baja California

Depth $\quad 125$ to $768 \mathrm{~m}$

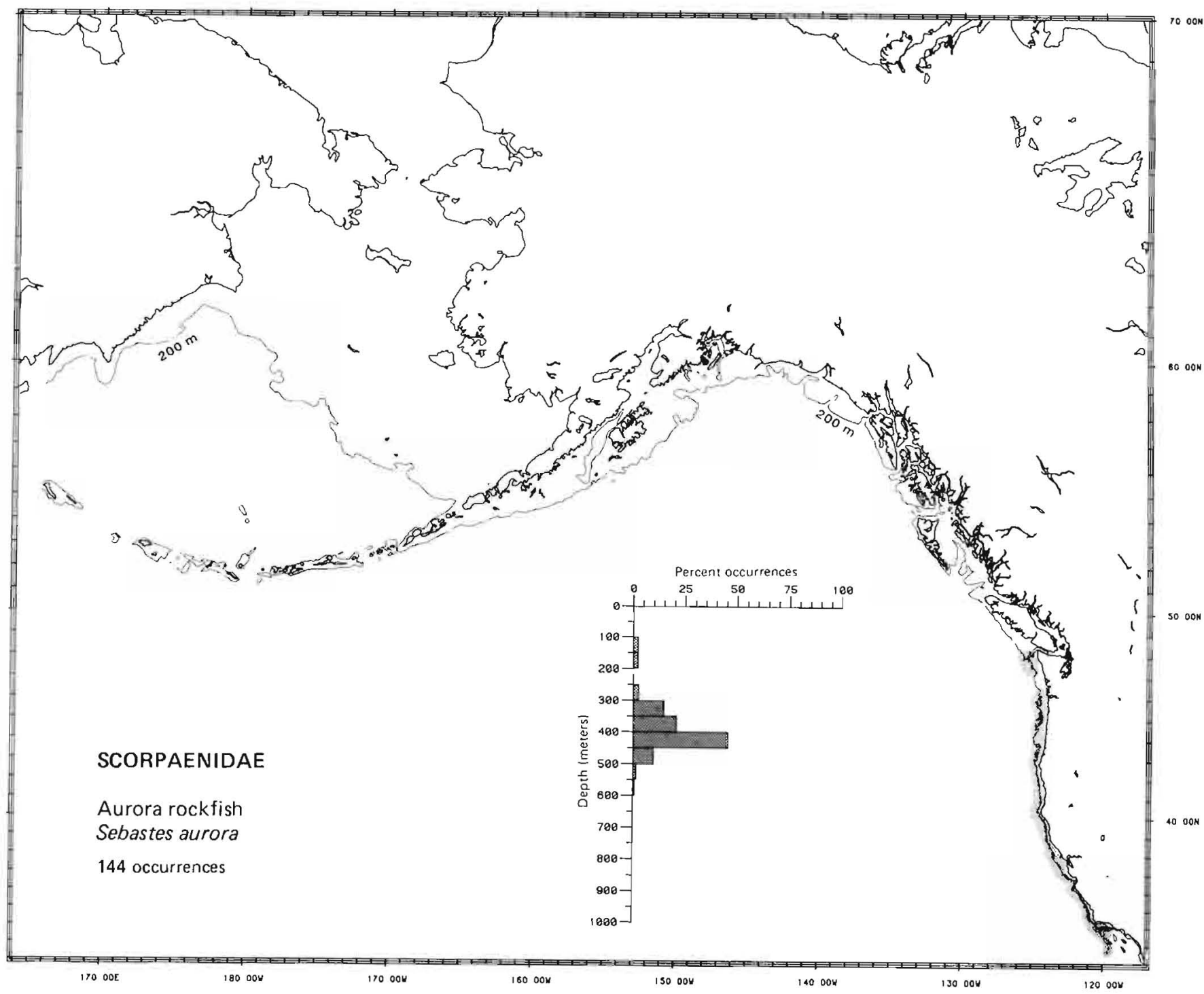


Literature Reported from the Bering Sea and Amchitka Island in the Aleutian Islands to San Diego, California (Howe 1981; Eschmeyer and Herald 1983), at depths of 49 to $550 \mathrm{~m}$ (Fedorov 1973a).

Survey data Found from northwest of Zhemchug Canyon on the central slope of the eastern Bering Sea and Tigalda Island in the Aleutian Islands to Morro Bay, California. Depth range 75 to $625 \mathrm{~m}$, most frequently (28.5\% of occurrences) on the mesobenthal slope from 250 to $300 \mathrm{~m}$, and $96.6 \%$ of occurrences from depths of 150 to $450 \mathrm{~m}$. Survey data provide a more precise description of the northern limit of this species in the Bering Sea and a new maximum depth record.

\section{Conclusions}

Zoogeography Eastern boreal Pacific

Life zone Outer shelf-mesobenthal (mesobenthal)

Range From Zhemchug Canyon in the Bering Sea and Amchitka Island in the Aleutian Islands to San Diego, California Depth $\quad 49$ to $625 \mathrm{~m}$

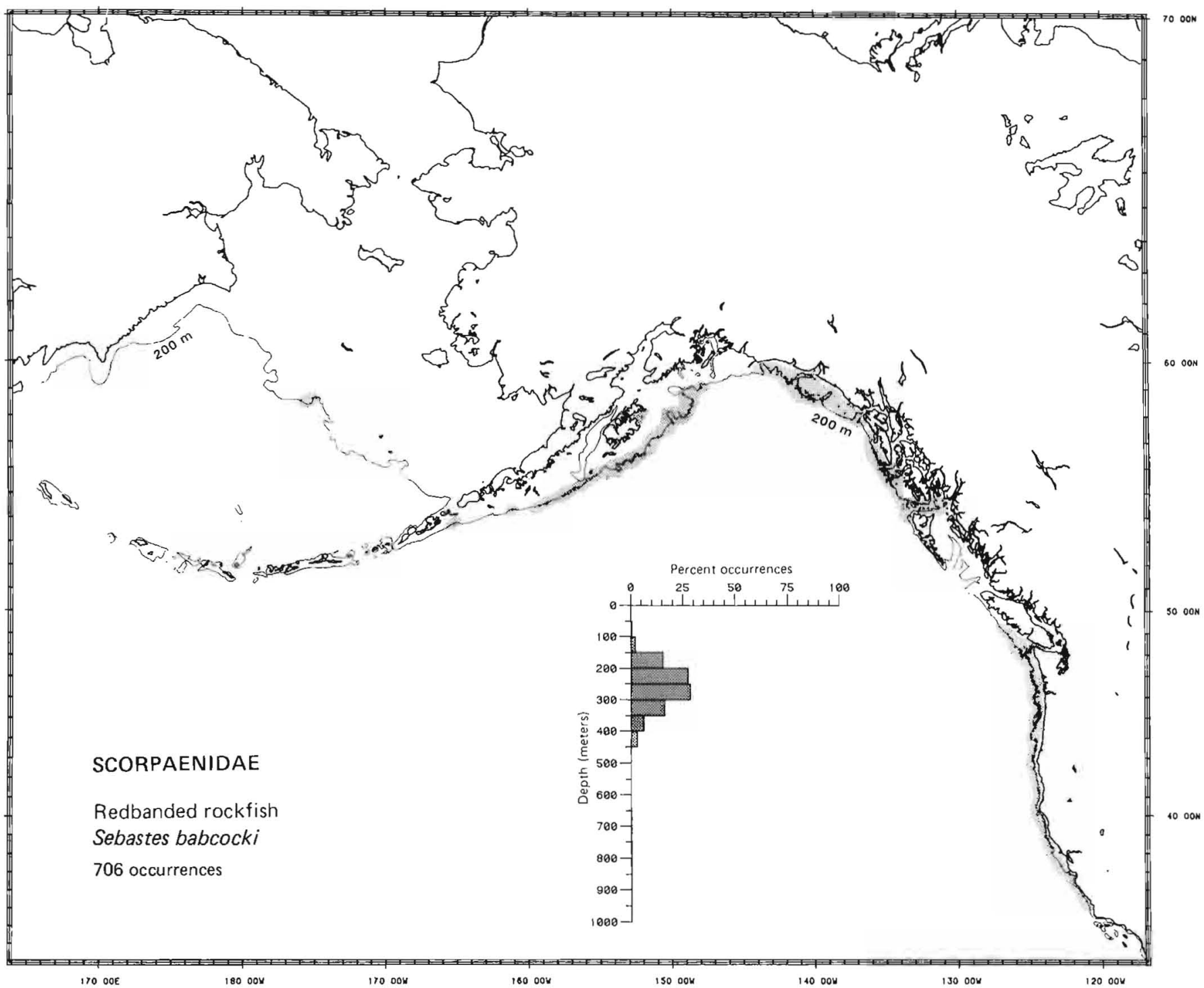


Literature Reported from southeastern Kamchatka to the northwest Bering Sea and Aleutian Islands south to Fort Bragg, California (Quast and Hall 1972; Eschmeyer and Herald 1983), at depths of 0 to $800 \mathrm{~m}$ (Fedorov 1973a; Howe 1981).

Survey data Found from Navarin Canyon on the northwest slope of the eastern Bering Sea and Stalemate Bank and Bowers Bank in the Aleutian Islands south to Point Conception, California. Depth range 25 to $875 \mathrm{~m}$, most frequently (19.6\% of occurrences) on the mesobenthal slope from 250 to $300 \mathrm{~m}$, and $95.2 \%$ of occurrences from depths of 50 to $650 \mathrm{~m}$. Survey data provide a more precise description of the northern and Aleutian limits, a new southern limit, and a new maximum depth record.

\section{Conclusions}

Zoogeography Eastern boreal Pacific

Life zone Middle shelf-bathybenthal (mesobenthal)

Range From southeastern Kamchatka to Navarin Canyon in the Bering Sea and in the Aleutian Islands to Stalemate Bank, and south to Point Conception, California

Depth $\quad 0$ to $875 \mathrm{~m}$

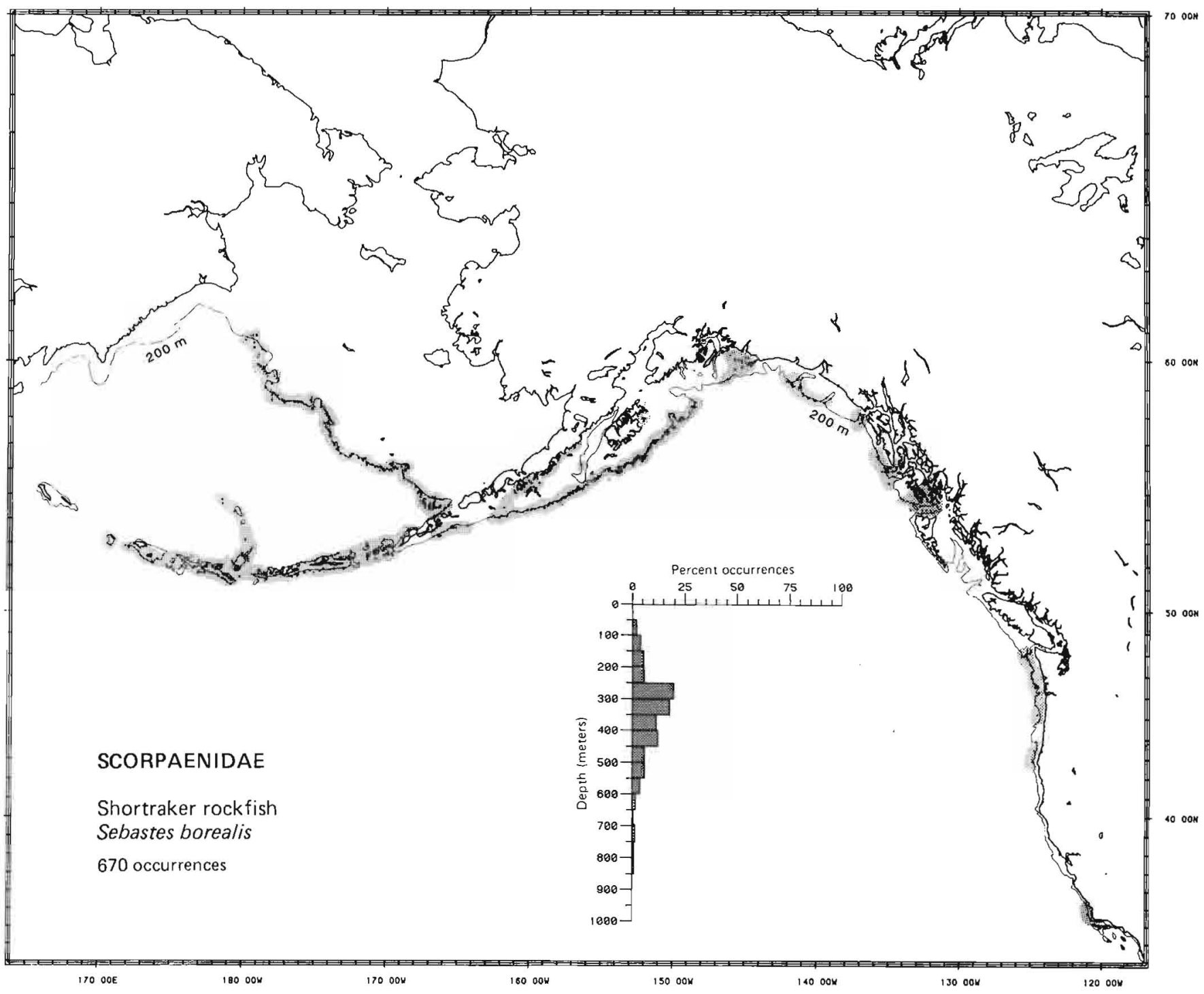


Literature Reported from the Bering Sea to Baja California (Howe 1981; Eschmeyer and Herald 1983), at depths of 0 to $366 \mathrm{~m}$ (Hart 1973; Eschmeyer and Herald 1983).

Survey data Found from Sanak Island in the Gulf of Alaska to Point Sur, California. Depth range 25 to $375 \mathrm{~m}$, most frequently (37.4\% of occurrences) on the outer shelf between 150 and $200 \mathrm{~m}$, and $94.4 \%$ of occurrences from depths of 100 to $300 \mathrm{~m}$. Survey data slightly extend the known maximum depth.

\section{Conclusions}

Zoogeography Eastern boreal Pacific

Life zone Outer shelf-mesobenthal (outer shelf)

Range From the Bering Sea to Baja California

Depth 0 to $375 \mathrm{~m}$

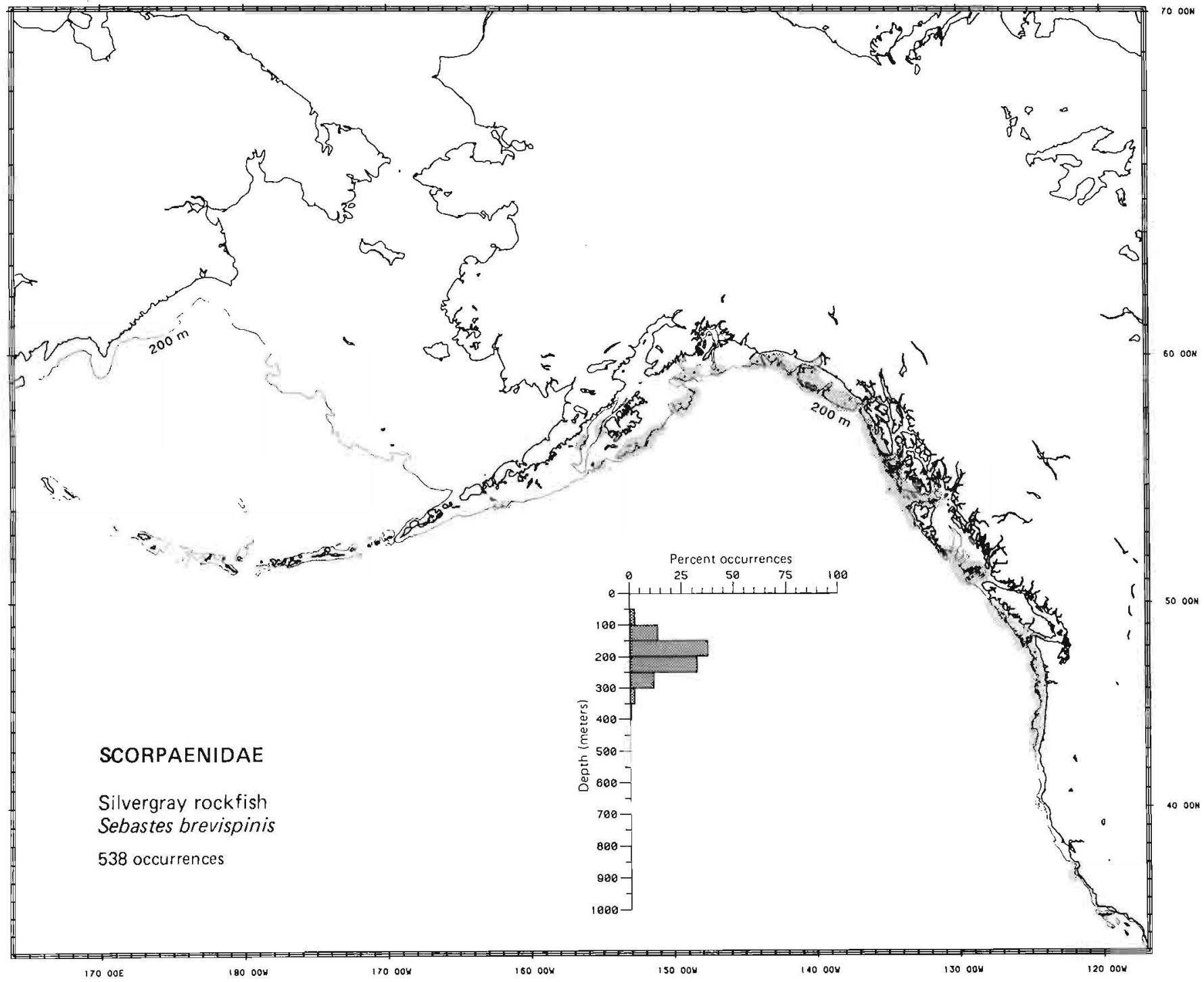


Taxonomic comment The dusky rockfish collected in these surveys may include a new species that is being described by J. Blackburn, Alaska Dep. Fish Game (Kessler 1985).

Literature Reported from the Bering Sea and from Amchitka Island in the Aleutian Islands to Johnstone Strait, British Columbia (Simenstad et al. 1977; Richards and Westrheim in press), at depths of 2 to $366 \mathrm{~m}$ (Howe 1981).

Survey data Found from Zhemchug Canyon on the central slope of the eastern Bering Sea and Agattu Island in the Aleutian Islands east to Kruzof Island in southeast Alaska. Depth range 75 to $525 \mathrm{~m}$, most frequently $(35.0 \%$ of occurrences) on the outer shelf from 150 to $200 \mathrm{~m}$, and $95.6 \%$ of occurrences from depths of 100 to $300 \mathrm{~m}$. Survey data provide a more precise description of the distribution in the Bering Sea and the Aleutian Islands, and a new maximum depth record.

\section{Conclusions}

Zoogeography Aleutian

Life zone Outer shelf-mesobenthal (outer shelf)

Range From Zhemchug Canyon in the Bering Sea and Agattu Island in the Aleutian Islands to Johnstone Strait, British Columbia

Depth 2 to $525 \mathrm{~m}$

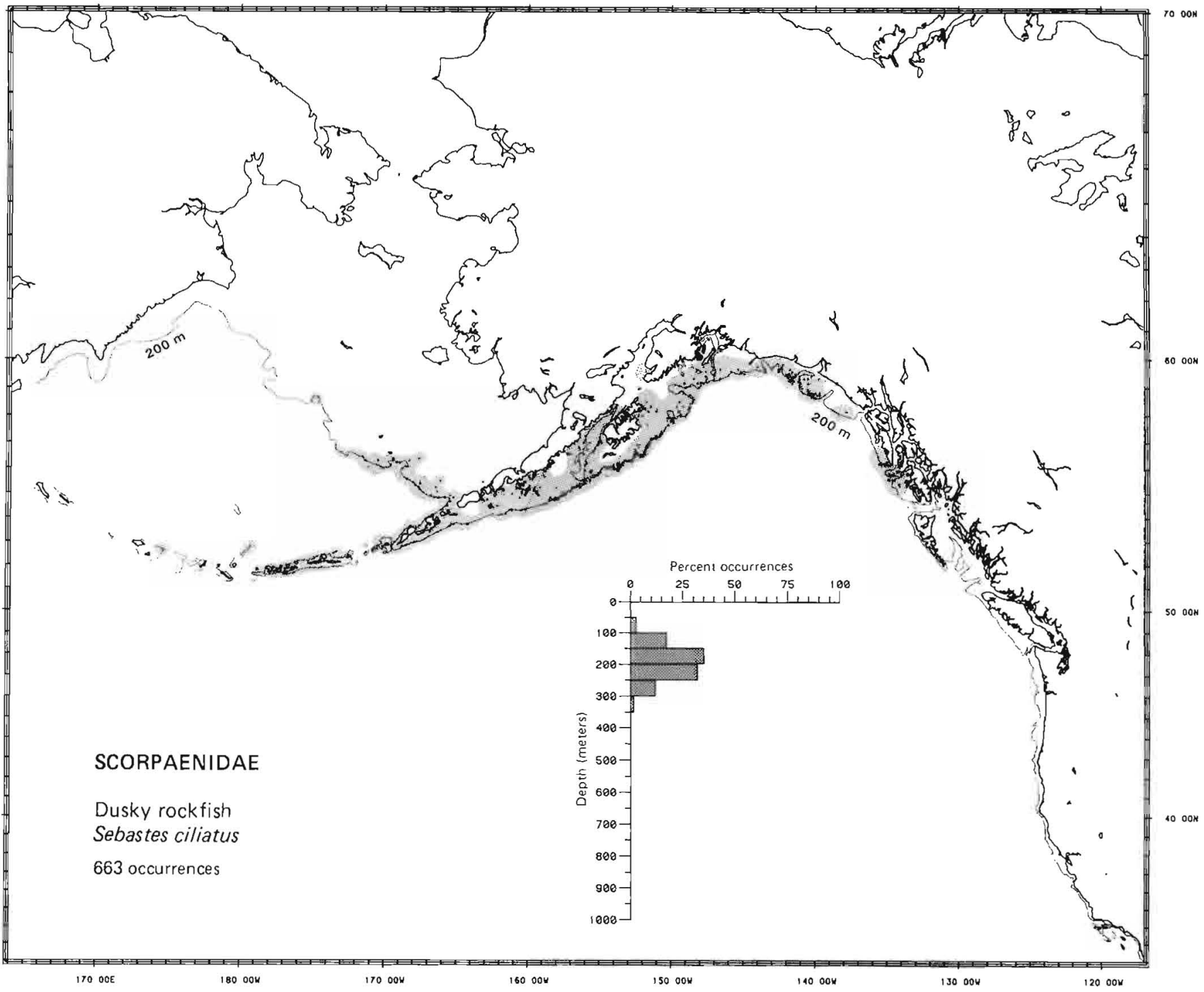


Literature Reported from the Bering Sea to Santa Catalina Island, California, at depths of 29 to $600 \mathrm{~m}$ (Fedorov $1973 \mathrm{a}$; Eschmeyer and Herald 1983).

Survey data Found from southeast of Zhemchug Canyon in the eastern Bering Sea and Tanaga Island in the Aleutian Islands south to Point Arguello, California. Depth range 25 to $475 \mathrm{~m}$, most frequently (26.9\% of occurrences) on the outer shelf between 100 and $150 \mathrm{~m}$, and $96.5 \%$ of occurrences from depths of 50 to $400 \mathrm{~m}$. Survey data provide a more precise description of the distribution in the Bering Sea and extend the known range in the Aleutian Islands.

\section{Conclusions}

Zoogeography Eastern boreal Pacific

Life zone Middle shelf-mesobenthal (outer shelf)

Range From southeast of Zhemchug Canyon in the Bering Sea to Santa Catalina Island, California

Depth 25 to $600 \mathrm{~m}$

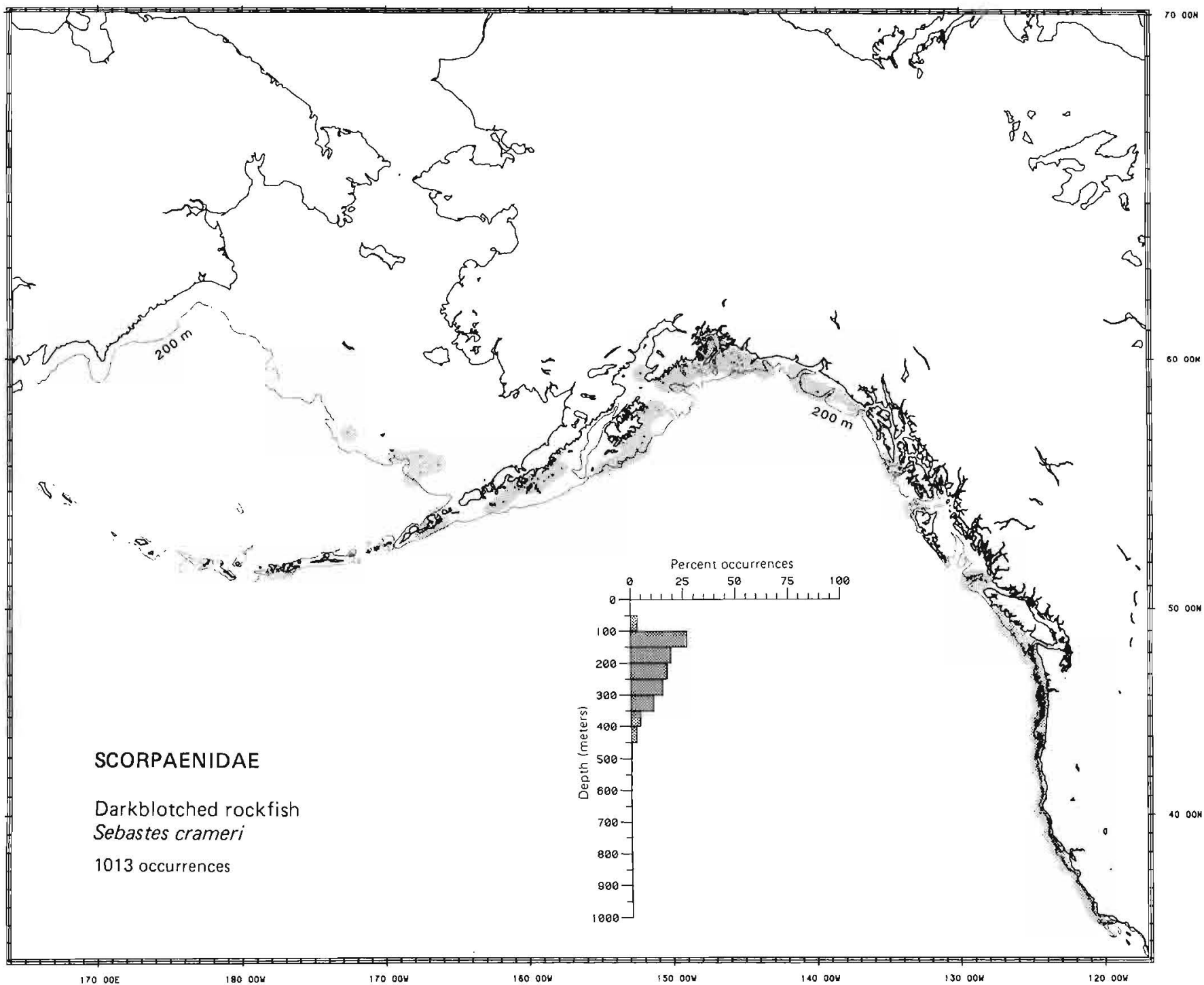


Literature Reported from the Alaska Peninsula to Cedros Island off Baja California and in the Gulf of California (Miller and Lea 1972; Hart 1973; Howe 1981), at depths of 0 to $800 \mathrm{~m}$ (Mitchell and Hunter 1970; Howe 1981).

Survey data Found from Prince William Sound in the Gulf of Alaska to the Santa Barbara Channel, California. Depth range 75 to $475 \mathrm{~m}$, most frequently (26.1\% of occurrences) on the mesobenthal slope between 200 and $250 \mathrm{~m}$, and $97.8 \%$ of occurrences from depths of 100 to $450 \mathrm{~m}$. Although survey data provide no new information on geographic or depth range, they do provide a more detailed center of depth distribution.

\section{Conclusions}

Zoogeography Eastern temperate Pacific

Life zone Outer shelf-mesobenthal (mesobenthal)

Range From the Alaska Peninsula to Cedros Island, Baja California, and the Gulf of California

Depth $\quad 0$ to $800 \mathrm{~m}$

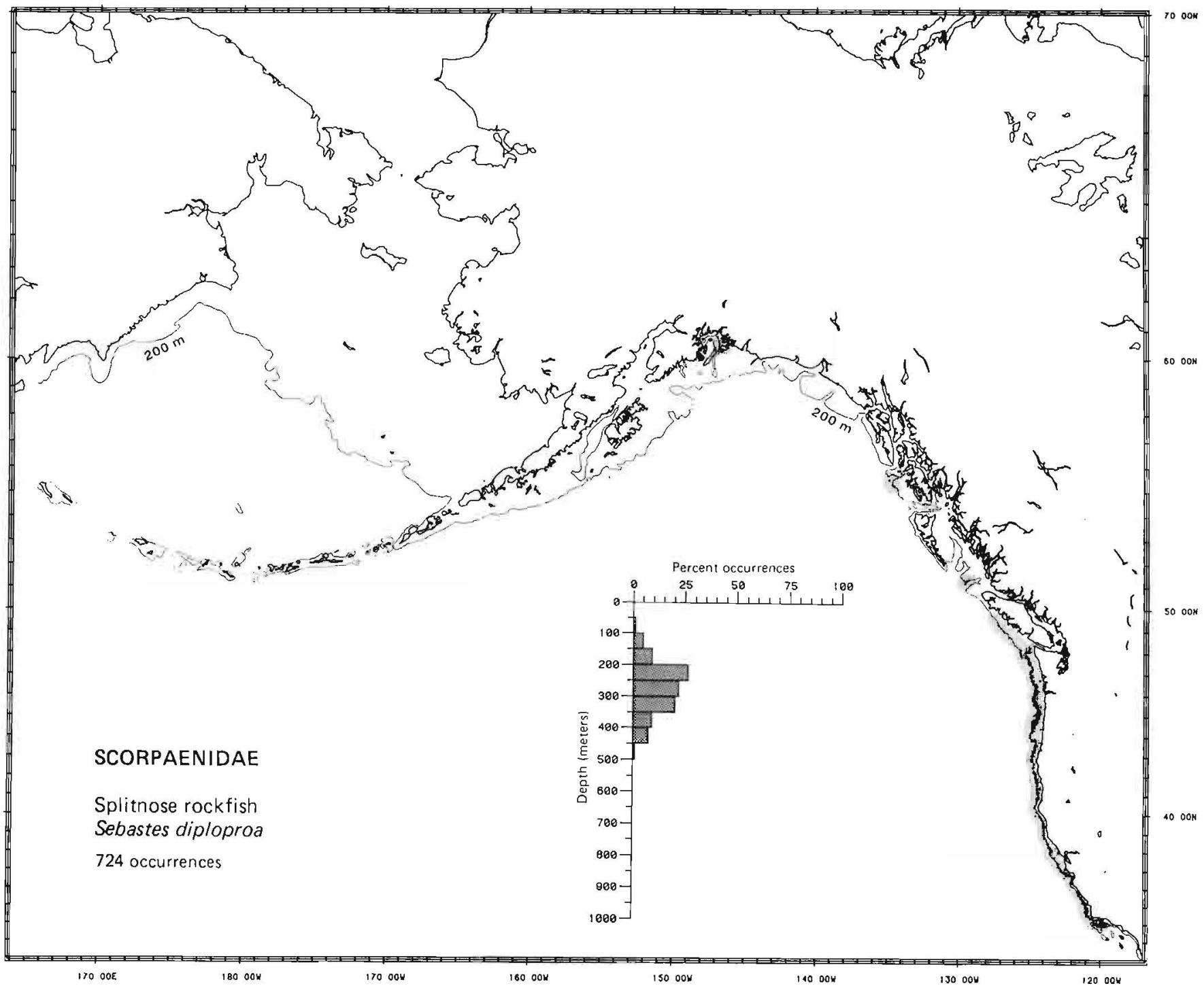


Literature Reported from Green Island near Montague Island in the northern Gulf of Alaska to Cedros Island, Baja California (Hart 1973; Eschmeyer and Herald 1983), at depths of 61 to $402 \mathrm{~m}$ (Eschmeyer and Herald 1983).

Survey data Found from offshore of Chirikof Island (southwest of Kodiak Island) in the Gulf of Alaska to Santa Cruz Island, California. Depth range 25 to $425 \mathrm{~m}$, most frequently (42.3\% of occurrences) on the outer shelf from 100 to $150 \mathrm{~m}$, and $95.0 \%$ of occurrences from depths between 50 and $250 \mathrm{~m}$. Survey data extend both the known depth range and known geographic range in the northwest.

\section{Conclusions}

Zoogeography Eastern boreal Pacific

Life zone Middle shelf-mesobenthal (outer shelf)

Range From Chirikof Island in the Gulf of Alaska to Cedros Island, Baja California

Depth 25 to $425 \mathrm{~m}$

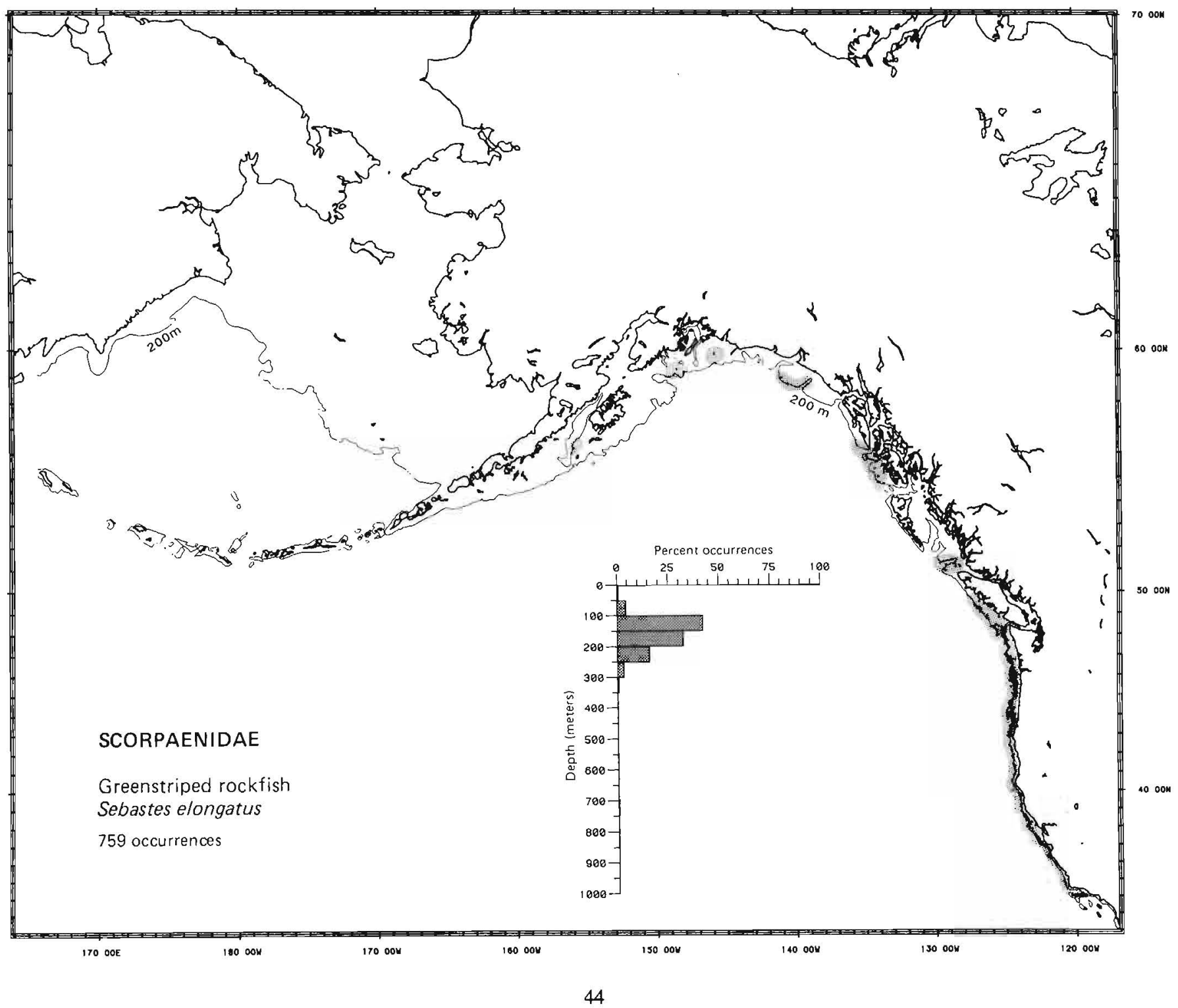


Literature Reported from southeastern Alaska to Todos Santos Bay, Baja California (Hart 1973; Eschmeyer and Herald 1983), at depths of 0 to $366 \mathrm{~m}$ (Howe 1981; Eschmeyer and Herald 1983).

Survey data Found from Middle Albatross Bank (east of Kodiak Island) to Point Arguello, California. Depth range 25 to $375 \mathrm{~m}$, most frequently (26.9\% of occurrences) on the outer shelf between 150 and $200 \mathrm{~m}$, and $99.2 \%$ of occurrences from depths of 50 to $350 \mathrm{~m}$. Survey data extend the northern limit and provide a slightly greater maximum known depth.

\section{Conclusions}

Zoogeography Eastern boreal Pacific

Life zone Middle shelf-mesobenthal (outer shelf)

Range From Middle Albatross Bank in the Gulf of Alaska to Todos Santos Bay, Baja California

Depth $\quad 0$ to $375 \mathrm{~m}$

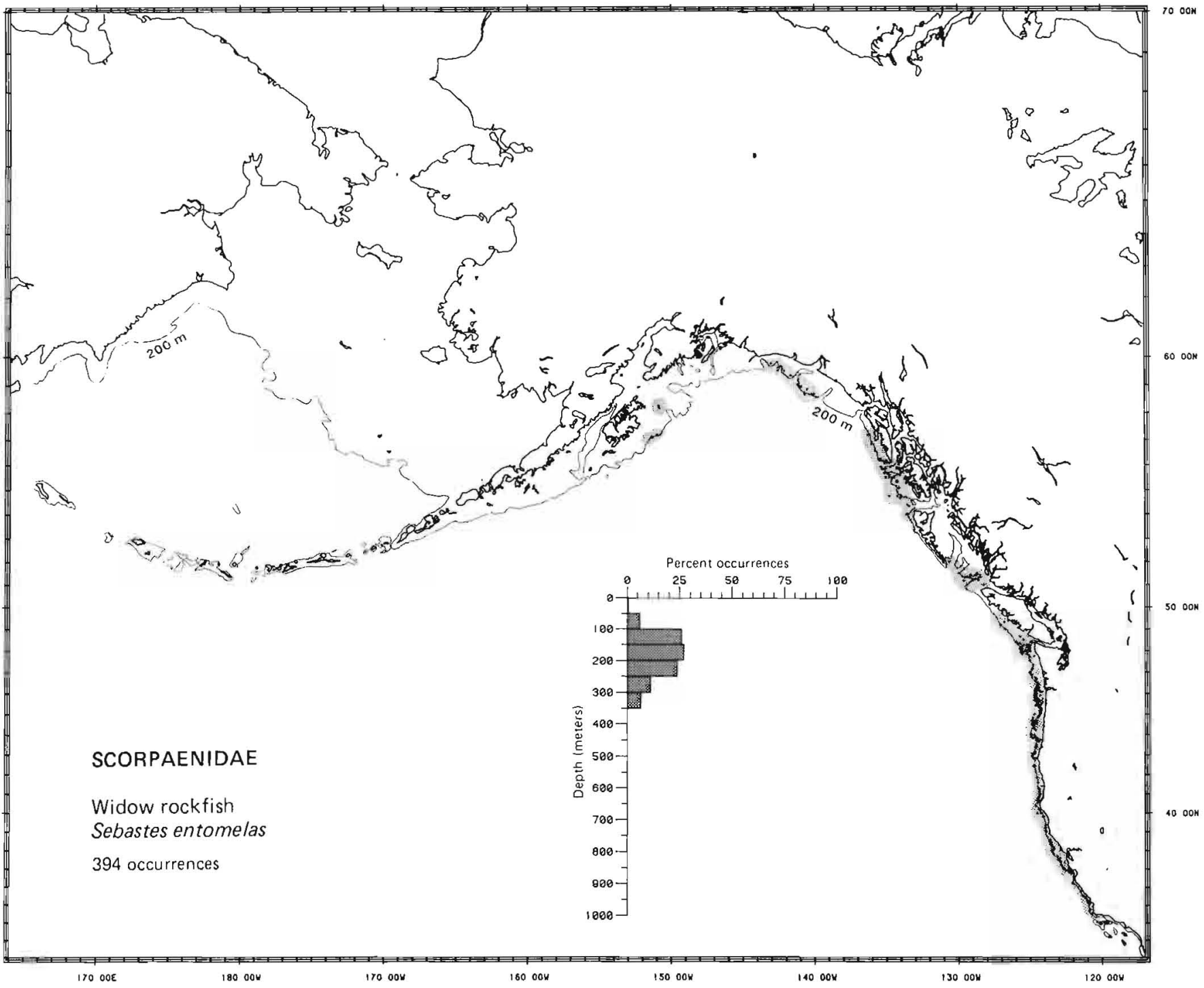


Literature Reported geographically from Kodiak Island, Alaska, to San Diego, California, and at depths of 0 to $549 \mathrm{~m}$ (Howe 1981 ; Eschmeyer and Herald 1983).

Survey data Found from Unalaska Island in the Aleutian Islands to Point Conception, California. Depth range 25 to $475 \mathrm{~m}$, most frequently (43.7\% of occurrences) on the outer shelf between 100 and $150 \mathrm{~m}$, and $96.4 \%$ of occurrences from depths of 50 to $300 \mathrm{~m}$. Survey data extend the northwestern known limit.

\section{Conclusions}

Zoogeography Eastern boreal Pacific

Life zone Middle shelf-mesobenthal (outer shelf)

Range From Unalaska Island, Alaska, to San Diego, California

Depth 0 to $549 \mathrm{~m}$

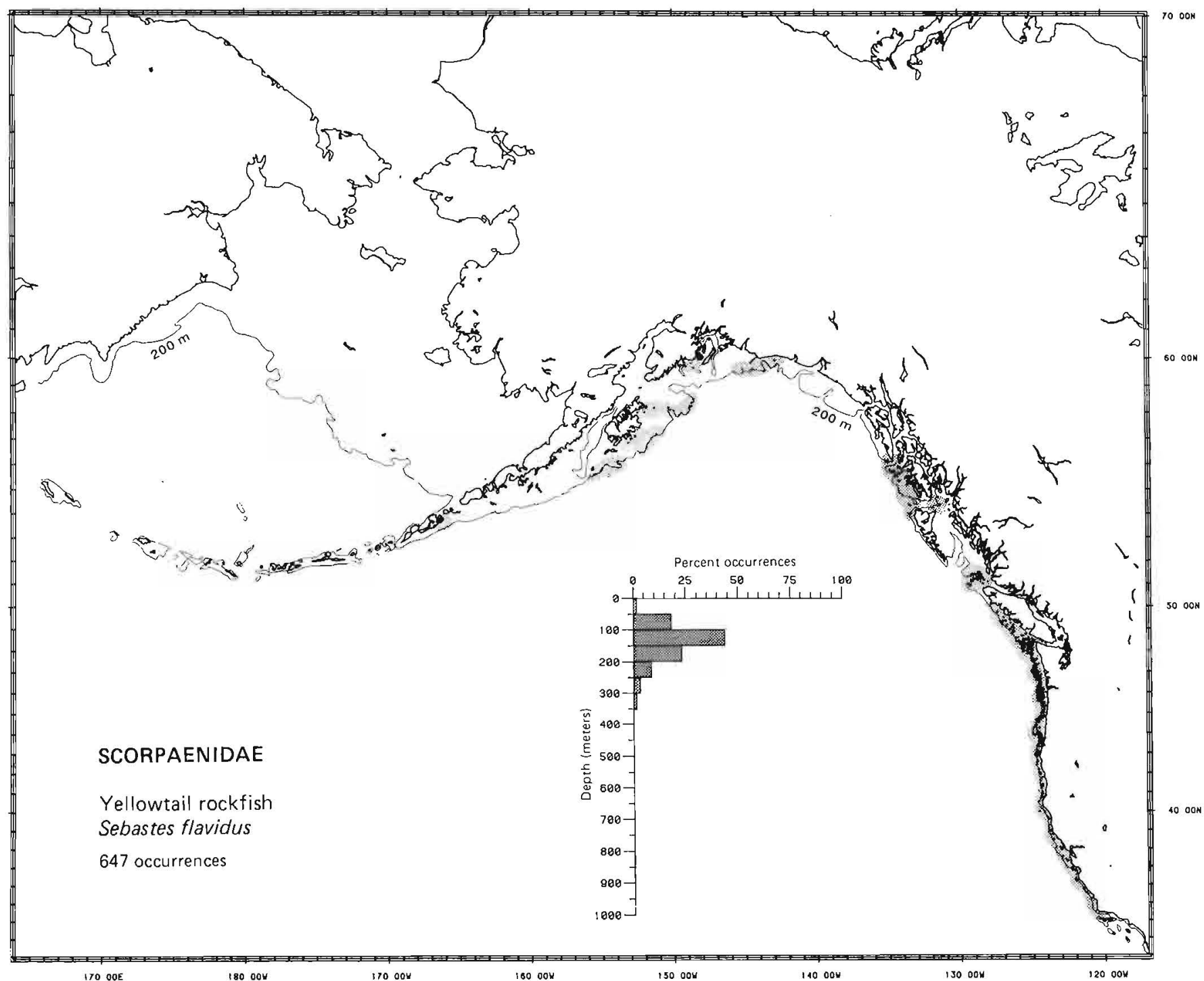


Literature Reported from northwestern Vancouver Island, British Columbia, to Magdalena Bay, Baja California Sur (Hart 1973), at depths of 0 to $329 \mathrm{~m}$ (Howe 1981; Eschmeyer and Herald 1983).

Survey data Found from Queen Charlotte Sound, British Columbia, to Oxnard, California. Depth range 25 to $425 \mathrm{~m}$, most frequently (33.7\% of occurrences) on the outer shelf from 100 to $150 \mathrm{~m}$, and $98.5 \%$ of occurrences from depths of 50 to $350 \mathrm{~m}$. Survey data provide new maximum depth and northern limits.

\section{Conclusions}

Zoogeography Oregonian-San Diegan

Life zone Middle shelf-mesobenthal (outer shelf)

Range From Queen Charlotte Sound, British Columbia, to Magdalena Bay, Baja California Sur

Depth 0 to $425 \mathrm{~m}$

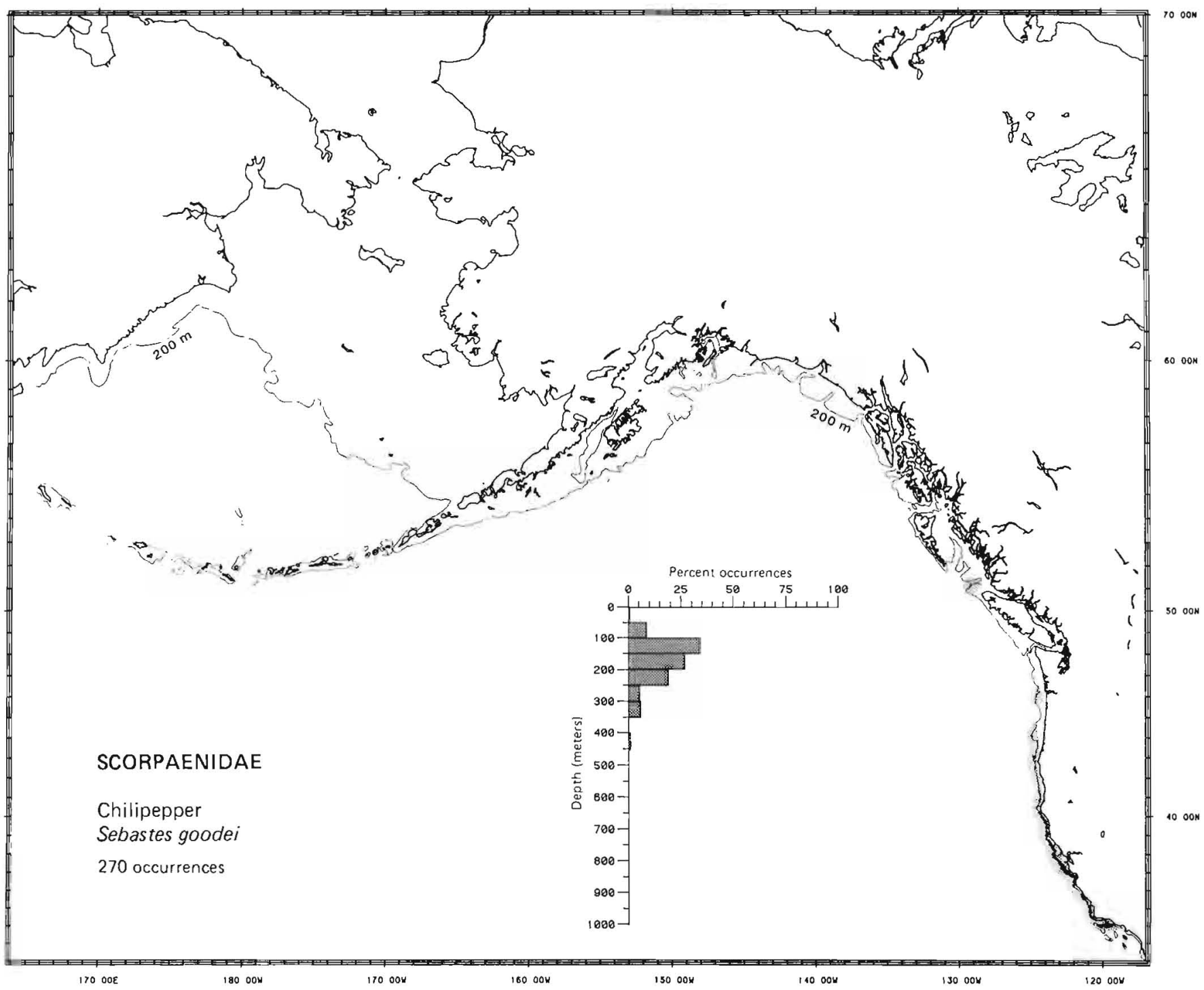


Literature Reported from Kodiak Island, Alaska, to Guadalupe Island off Baja California, at depths of 75 to 549 m (Hart 1973 ; Howe 1981; Eschmeyer and Herald 1983).

Survey data Found from offshore of Icy Bay in the Gulf of Alaska to Monterey Bay, California. Depth range 25 to $425 \mathrm{~m}$, most frequently (32.1\% of occurrences) on the upper slope between 200 and $250 \mathrm{~m}$, and $96.1 \%$ of occurrences from depths of 100 to $350 \mathrm{~m}$. Survey data provide a new minimum known depth.

\section{Conclusions}

Zoogeography Eastern boreal Pacific

Life zone Outer shelf-mesobenthal (mesobenthal)

Range $\quad$ From Kodiak Island, Alaska, to Guadalupe Island, Baja California

Depth 25 to $549 \mathrm{~m}$

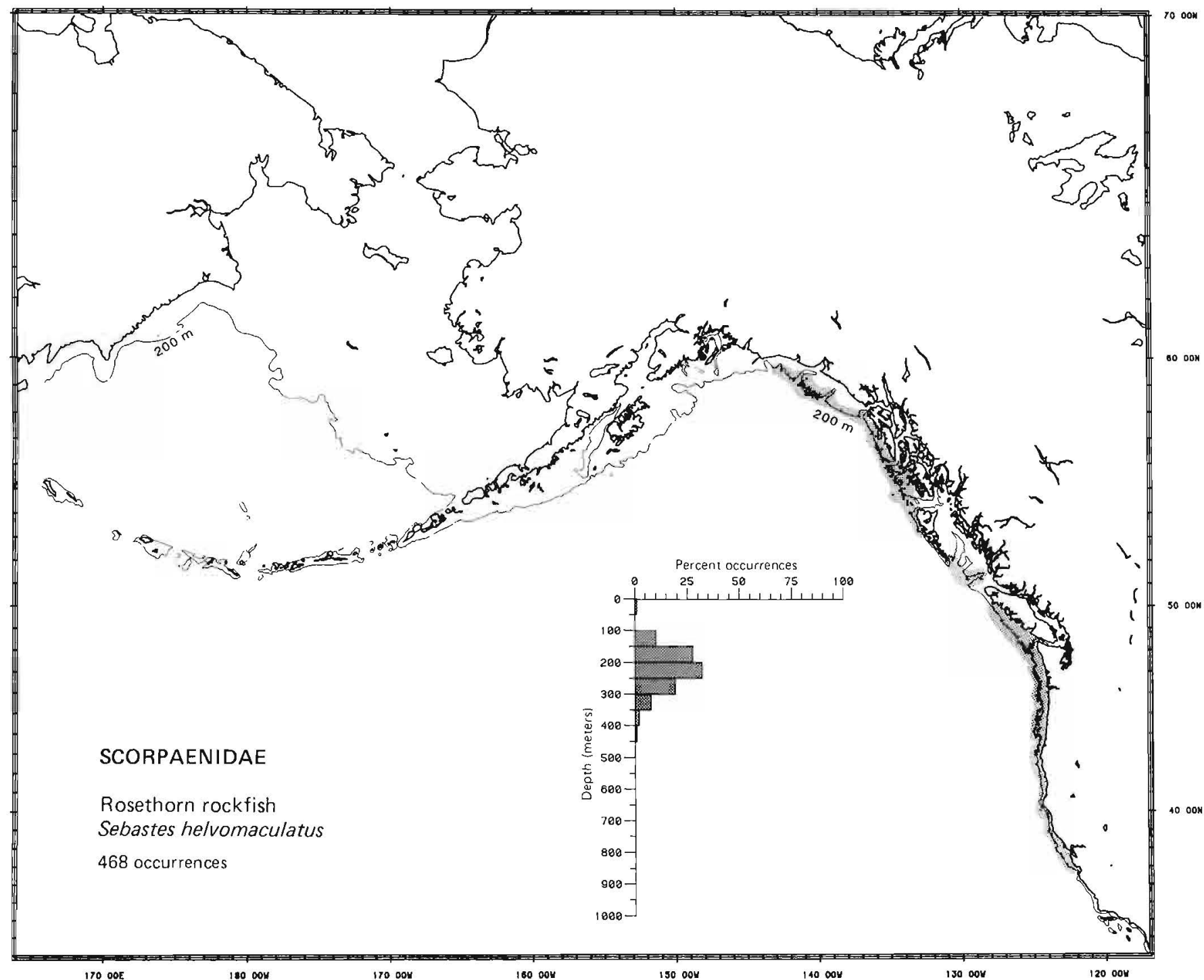


Literature Reported from La Perouse Bank, Vancouver Island, to Benito Island, Baja California (Hart 1973; Moser et al. 1977), at depths of 0 to $283 \mathrm{~m}$ (Howe 1981; Eschmeyer and Herald 1983).

Survey data Found from Granite Island, Kenai Peninsula, Alaska, to the Santa Barbara Channel, California. Depth range 25 to $475 \mathrm{~m}$, most frequently (37.3\% of occurrences) on the outer shelf from 100 to $150 \mathrm{~m}$, and $97.5 \%$ of occurrences from depths of 50 to $350 \mathrm{~m}$. Survey data extend the northernmost known limit and maximum known depth. However, the northern record is extremely far removed from the next most northerly records (La Perouse Bank, Vancouver Island, in the literature and Grays Harbor, Washington, in the survey data) and hence must be regarded as questionable.

\section{Conclusions}

Zoogeography Oregonian-San Diegan

Life zone Middle shelf-mesobenthal (outer shelf)

Range From La Perouse Bank, Vancouver Island (possibly from Granite Island off the Kenai Peninsula, Alaska), to Benito Island, Baja California

Depth $\quad 0$ to $350 \mathrm{~m}$

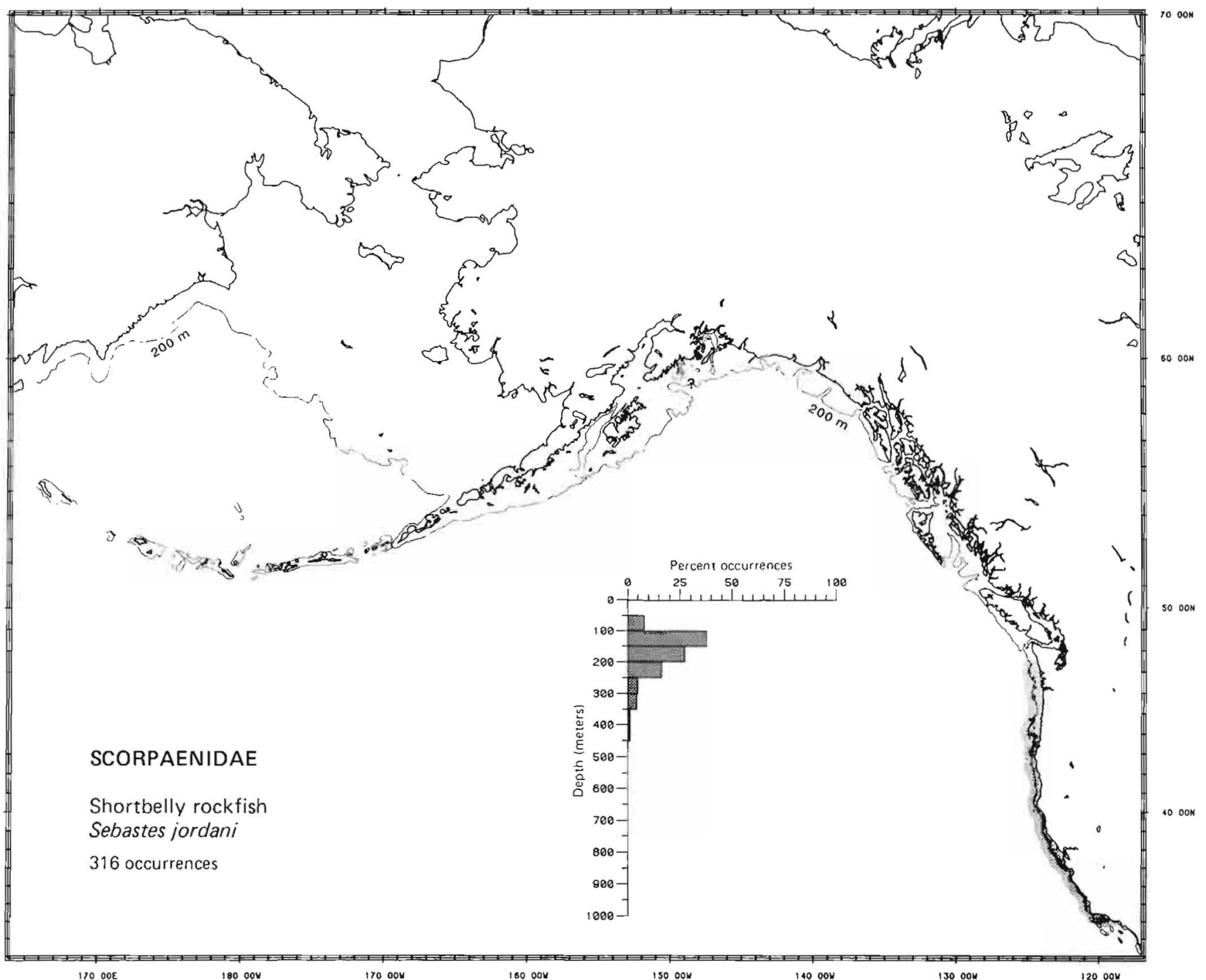




\section{BLACKGILL ROCKFISH, Sebastes melanostomus}

(Eigenmann and Eigenmann 1890)

Literature Reported from Washington to Cedros Island, Baja California (Hart 1973; Eschmeyer and Herald 1983). Previously reported from the Bering Sea and Aleutian Islands, but these were presumably records of the closely related shortraker rockfish, Sebastes borealis, which was not described until 1970 (Barsukov 1970; Tsuyuki and Westrheim 1970; Hart 1973). Reported at depths of 218 to $768 \mathrm{~m}$ (Miller and Lea 1972; Hart 1973).

Survey data Found from Pribilof Canyon in the southeastern Bering Sea to the Patton Escarpment off southern California. Depth range 125 to $625 \mathrm{~m}$, most frequently (33.3\% of samples) on the mesobenthal slope between 400 and $450 \mathrm{~m}$, and $94.8 \%$ of occurrences from depths of 250 to $600 \mathrm{~m}$. Survey data include records of this species in the Bering Sea and Gulf of Alaska. Because the survey data extend as far back as 1953, before the discovery of the shortraker rockfish, these records may actually not be of the blackgill rockfish. Thus until recent verifiable records of the blackgill rockfish are obtained from these northern areas, Washington will be considered the northern limit for the species. The survey data extend the shallow edge of the known range of this species to $125 \mathrm{~m}$.

\section{Conclusions}

$\begin{array}{ll}\text { Zoogeography } & \text { Oregonian-San Diegan } \\ \text { Life zone } & \text { Mesobenthal-bathybenthal (mesobenthal) } \\ \text { Range } & \text { From Washington to Cedros Island, Baja California } \\ \text { Depth } & 125 \text { to } 768 \mathrm{~m}\end{array}$

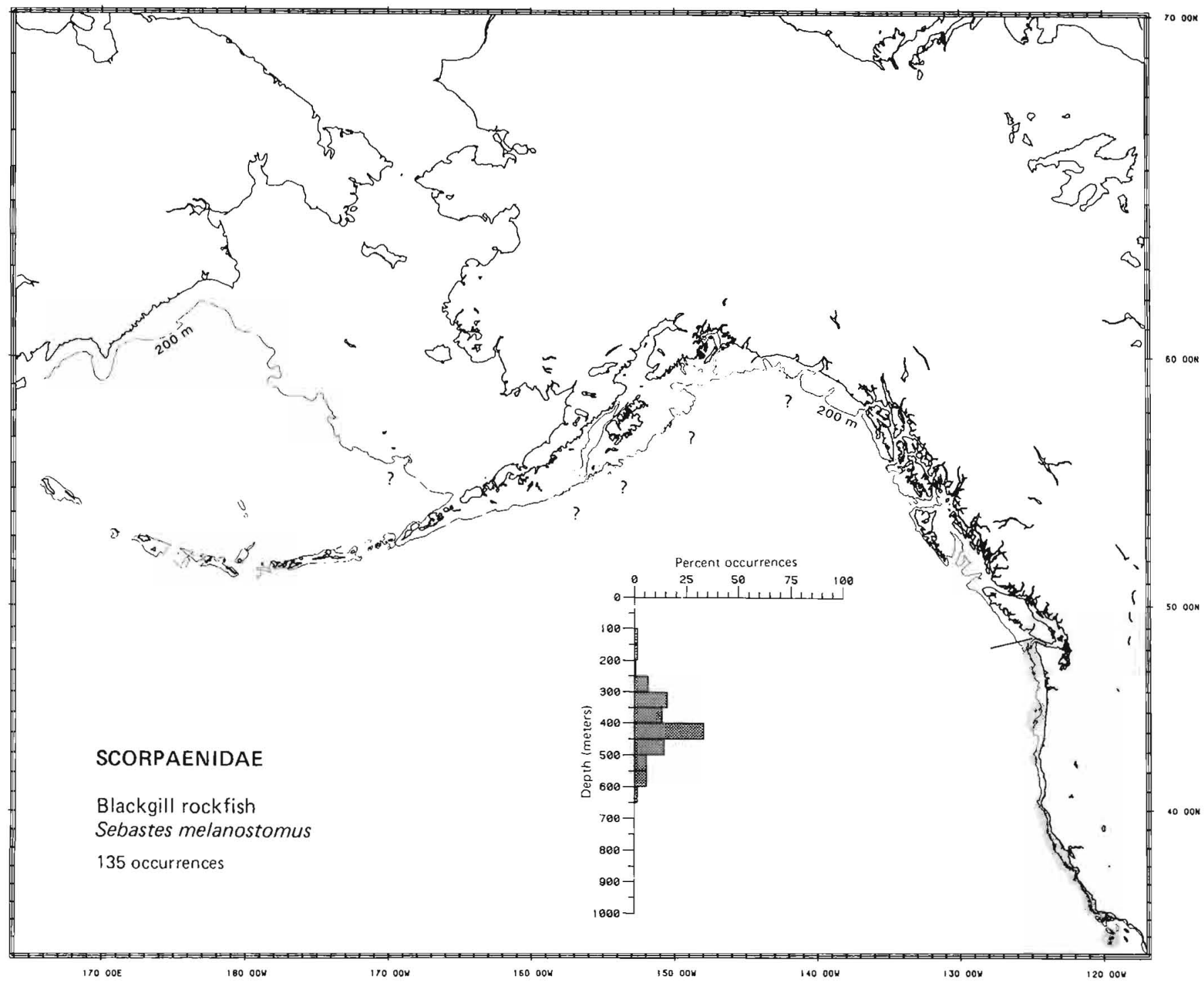


Literature Reported from Kodiak Island, Alaska, to Punta Blanca, Baja California (Miller and Lea 1972), at depths of 0 to $320 \mathrm{~m}$ (Howe 1981; Eschmeyer and Herald 1983).

Survey data Found from Stepovak Bay on the Alaska Peninsula to south of San Nicolas Island, California. Depth range 25 to $475 \mathrm{~m}$, most frequently (31.2\% of occurrences) on the outer shelf from 100 to $150 \mathrm{~m}$, and $96.7 \%$ of occurrences from depths of 50 to $300 \mathrm{~m}$. Survey data extend the known range to the northwest and to a greater depth.

\section{Conclusions}

Zoogeography Eastern boreal Pacific-San Diegan

Life zone Middle shelf-mesobenthal (outer shelf)

Range From Stepovak Bay on the Alaska Peninsula to Punta Blanca, Baja California

Depth $\quad 0$ to $475 \mathrm{~m}$

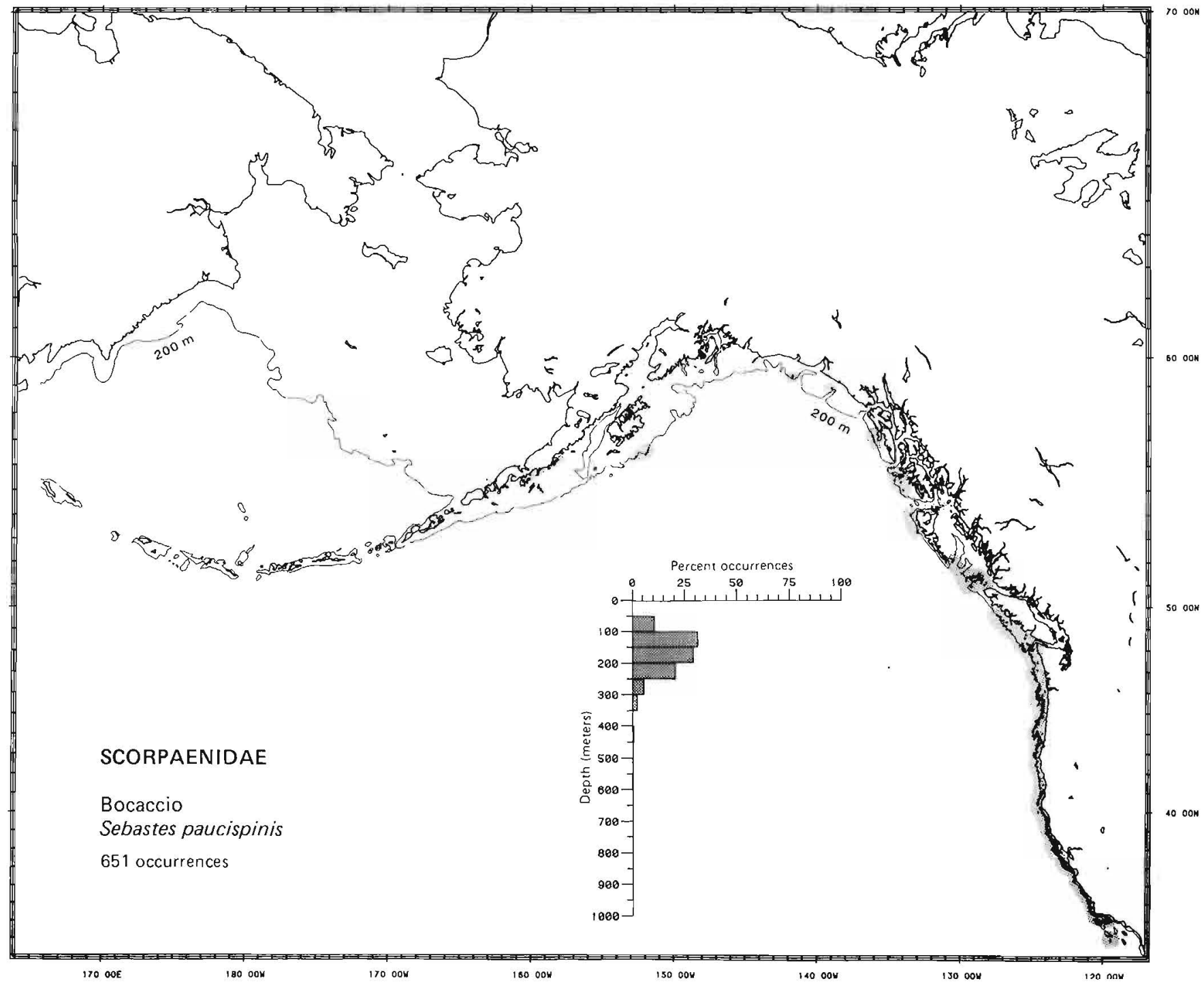


Literature Reported from Cape Bartolome, Alaska, to Cape Colnett, Baja California (Miller and Lea 1972), at depths of 0 to $366 \mathrm{~m}$ (Hart 1973; Howe 1981).

Survey data Found from the slope south of Shelikof Strait in the Gulf of Alaska to Santa Barbara, California. Depth range 25 to $425 \mathrm{~m}$, most frequently ( $41.4 \%$ of occurrences) on the outer shelf between 100 and $150 \mathrm{~m}$, and $95.2 \%$ of occurrences from depths of 50 to $250 \mathrm{~m}$. Survey data extend the known range into the western Gulf of Alaska and provide a greater maximum depth.

\section{Conclusions}

Zoogeography Eastern boreal Pacific

Life zone Middle shelf-mesobenthal (outer shelf)

Range From south of Shelikof Strait in the Gulf of Alaska to Cape Colnett, Baja California

Depth 0 to $425 \mathrm{~m}$

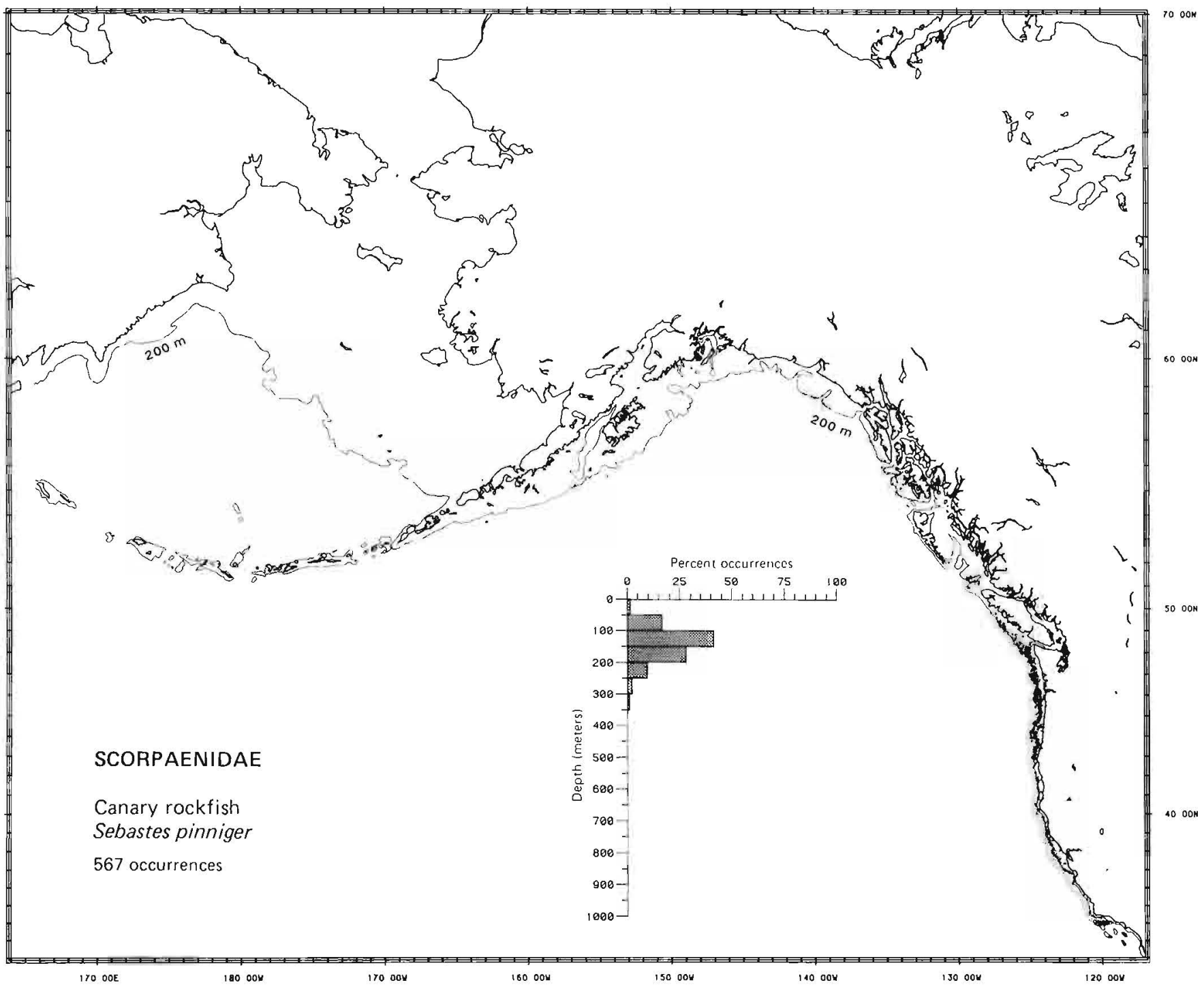


Literature Reported from eastern Kamchatka to the Bering Sea, west in the Aleutian Islands to Amchitka Island, and east to Yakutat, Alaska (Quast and Hall 1972; Simenstad et al. 1977; Eschmeyer and Herald 1983), at depths of 73 to $358 \mathrm{~m}$ (Eschmeyer and Herald 1983).

Survey data Found from Pervenets Canyon on the northwest slope of the eastern Bering Sea and Stalemate Bank in the Aleutian Islands east to northern Graham Island, British Columbia. Depth range 75 to $625 \mathrm{~m}$, most frequently (29.6\% of occurrences) on the outer shelf from 150 to $200 \mathrm{~m}$, and $96.7 \%$ of occurrences from depths of 50 to $350 \mathrm{~m}$. Survey data provide a more precise distribution in the Bering Sea and Aleutian Islands, extend the known range to the east, and provide a new maximum depth.

\section{Conclusions}

Zoogeography

Life zone

Range

\section{Aleutian}

Middle shelf-mesobenthal (outer shelf)

Depth

$$
\text { Columbia }
$$

$$
73 \text { to } 625 \mathrm{~m}
$$

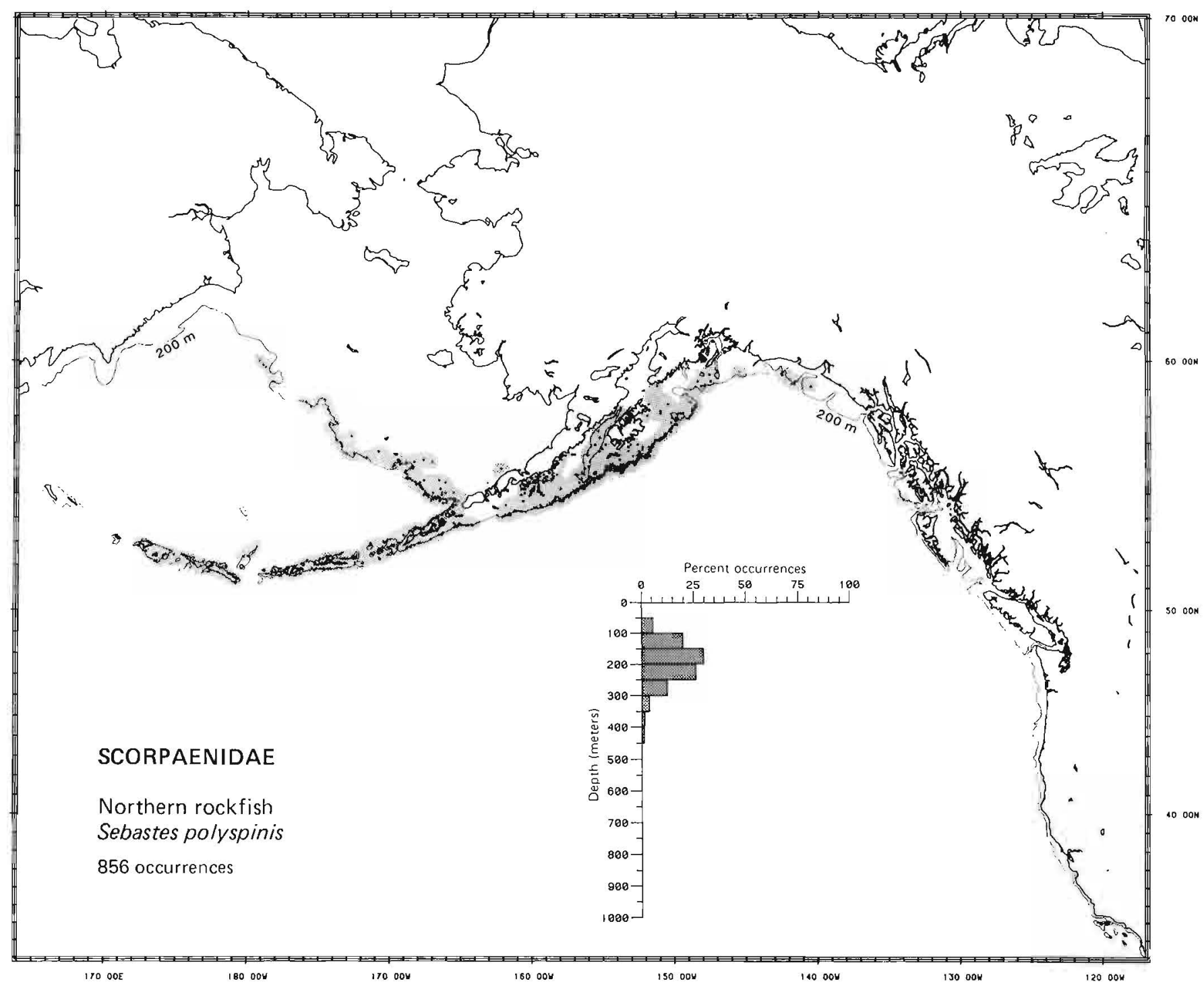


Literature Reported from the Bering Sea and Amchitka Island in the Aleutian Islands to San Diego (Miller and Lea 1972; Simenstad et al. 1977; Eschmeyer and Herald 1983) at depths of 12 to $366 \mathrm{~m}$ (Hart 1973; Eschmeyer and Herald 1983).

Survey data Taken from Pribilof Canyon in the southeastern Bering Sea and Atka Island in the Aleutian Islands to Bodega Bay, California. Depth range 75 to $425 \mathrm{~m}$, most frequently (33.3\% of occurrences) on the outer shelf from 150 to $200 \mathrm{~m}$, and $95.5 \%$ of occurrences from depths of 100 to $350 \mathrm{~m}$. Survey data provide a more precise range in the Bering Sea and a new maximum depth record.

\section{Conclusions}

Zoogeography Eastern boreal Pacific

Life zone Outer shelf-mesobenthal (outer shelf)

Range From the Pribilof Canyon, Bering Sea, and Amchitka Island in the Aleutian Islands to San Diego, California

Depth $\quad 12$ to $425 \mathrm{~m}$

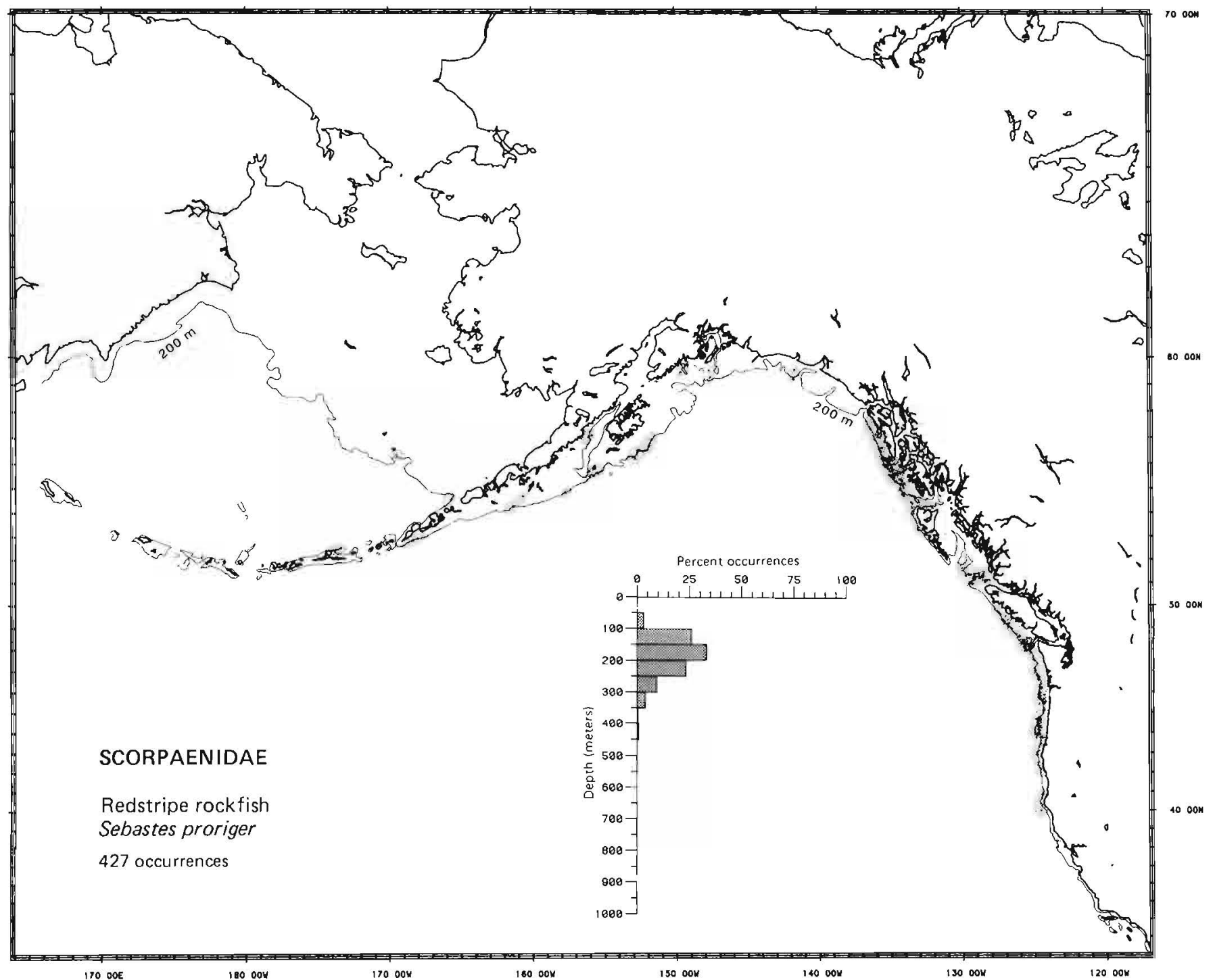


Literature Reported from the Gulf of Alaska to Ensenada, Baja California, from 37 to $549 \mathrm{~m}$ in depth (Miller and Lea 1972; Howe 1981; Eschmeyer and Herald 1983).

Survey data Found from Umnak Island in the Aleutian Islands to San Luis Obispo, California. Depth range 25 to $475 \mathrm{~m}$, most frequently (30.9\% of occurrences) on the outer shelf from 150 to $200 \mathrm{~m}$, and $95.3 \%$ of occurrences from depths of 50 to $400 \mathrm{~m}$. Survey data provide a more precise distribution of this species in the Gulf of Alaska and a slightly shallower minimum depth.

\section{Conclusions}

Zoogeography Eastern boreal Pacific

Life zone Middle shelf-mesobenthal (outer shelf)

Range $\quad$ From Umnak Island, Alaska, to Ensenada, Baja California

Depth 25 to $549 \mathrm{~m}$

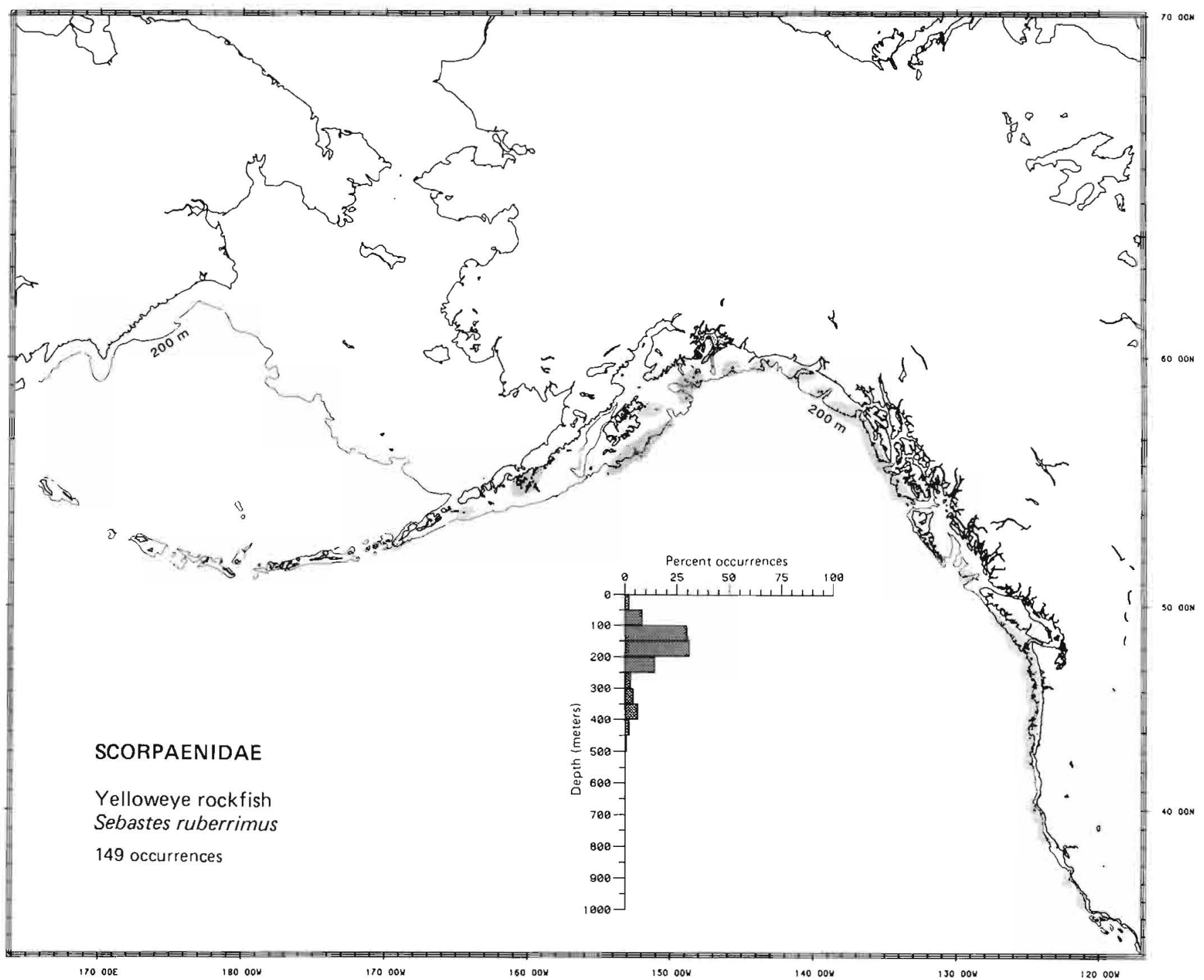


Taxonomic comment The redbanded rockfish, Sebastes babcocki, was considered to be the same species as the flag rockfish, with babcocki being a junior synonym of rubrivinctus, from 1928 to 1972. Rosenblatt and Chen (1972) presented evidence to separate the two as distinct species.

Literature Reported from San Francisco, California, to Cape San Quintin, Baja California (Miller and Lea 1972). Because of the confusion of redbanded rockfish with flag rockfish, probably all fish identified as flag rockfish north of San Francisco from 1928 to 1972 were redbanded rockfish (Rosenblatt and Chen 1972). The flag rockfish has been reported at depths of 0 to $302 \mathrm{~m}$ (Howe 1981 ).

Survey data From south of the Kenai Peninsula, Alaska, to the Santa Barbara Channel, California. Depth range 125 to $425 \mathrm{~m}$, most frequently (34.3\% of occurrences) on the upper slope between 200 and $250 \mathrm{~m}$, and $95.2 \%$ of occurrences from depths $<350 \mathrm{~m}$. Survey data show a geographic range for this species that is misleading. Because the data include samples collected as far back as 1953, records of flag rockfish north of San Francisco (and possibly some south of there) were probably records of redbanded rockfish. The two species were probably correctly distinguished after the mid-1970's. It is also not certain how the confusion of these two species affects the depth frequency distribution found in the data. Thus the range of this species will be regarded conservatively as being that found in the literature.

\section{Conclusions}

Zoogeography Oregonian-San Diegan

Life zone Inner shelf-mesobenthal (mesobenthal)

Range From San Francisco, California, to Cape San Quintin, Baja California

Depth $\quad 0$ to $302 \mathrm{~m}$ (possibly to $425 \mathrm{~m}$ )

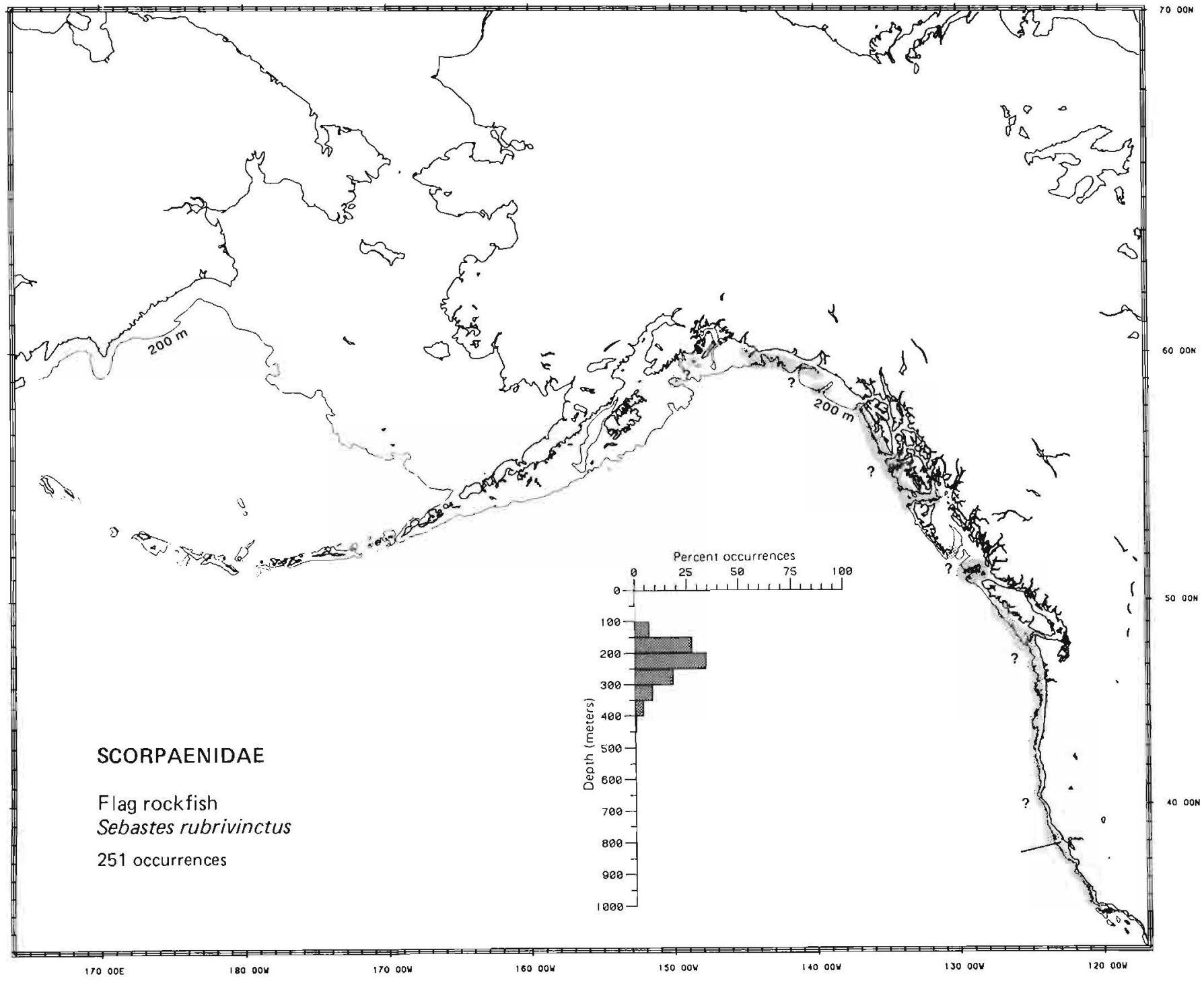


Literature Reported from southeastern Alaska to Rompiente Point, Baja California Sur (Milier and Lea 1972), at depths of 10 to $547 \mathrm{~m}$ (Howe 1981; Allen 1982).

Survey data Found from Yakutat Bay. Alaska, to the Santa Barbara Channel, California. Depth range 25 to $475 \mathrm{~m}$, most frequently ( $31.9 \%$ of occurrences) on the outer shelf between 150 to $200 \mathrm{~m}$, and $97.0 \%$ of occurrences from depths $<350 \mathrm{~m}$. Survey data provide a more precise northern limit in southeastern Alaska.

\section{Conclusions}

Zoogeography Oregonian-San Diegan

Life zone Inner shelf-mesobenthal (outer shelf)

Range From Yakutat Bay, Alaska, to Rompiente Point, Baja California Sur

Depth $\quad 10$ to $547 \mathrm{~m}$

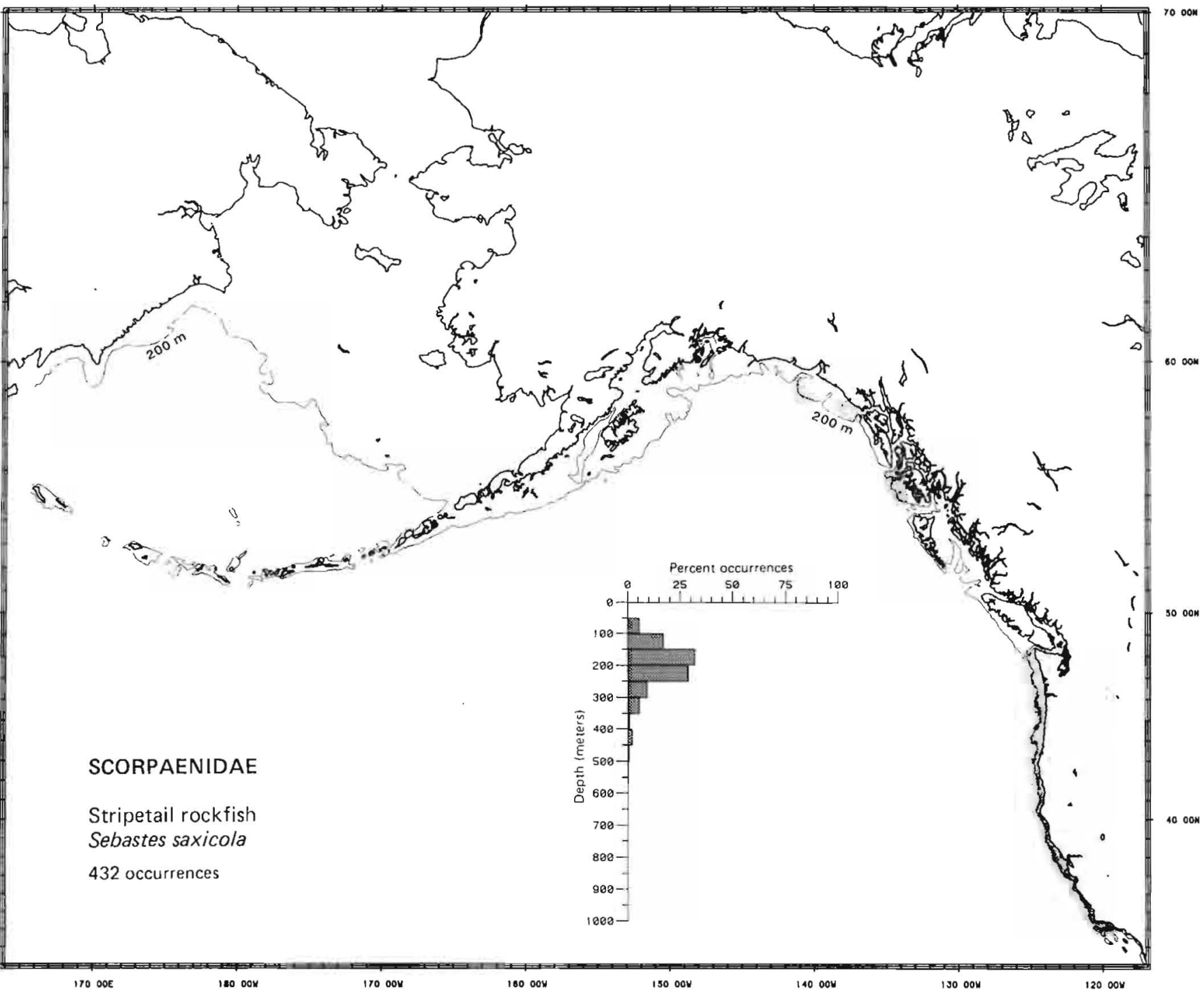


Literature Reported from Unimak Pass in the Aleutian Islands to Goose Island Bank in Queen Charlotte Sound, British Columbia (Hart 1973), at depths of 70 to $558 \mathrm{~m}$ (Howe 1981; Eschmeyer and Herald 1983).

Survey data Found from Bowers Bank in the Aleutian Islands to Bodega Bay, California. Depth range 125 to $425 \mathrm{~m}$, most frequently (35.4\% of occurrences) on the outer shelf between 150 and $200 \mathrm{~m}$, and $94.3 \%$ of occurrences from depths $<300 \mathrm{~m}$. Survey data extend the known range to the west in the Aleutians and to the south. Records of this species off Cape Flattery, Washington, and Bodega Bay, California, are regarded as questionable at this time.

\section{Conclusions}

Zoogeography Aleutian

Life zone Inner shelf-mesobenthal (outer shelf)

Range From Bowers Bank in the Aleutians to Goose Island Bank, Queen Charlotte Sound, British Columbia (possibly to Bodega Bay, California)

Depth $\quad 70$ to $558 \mathrm{~m}$

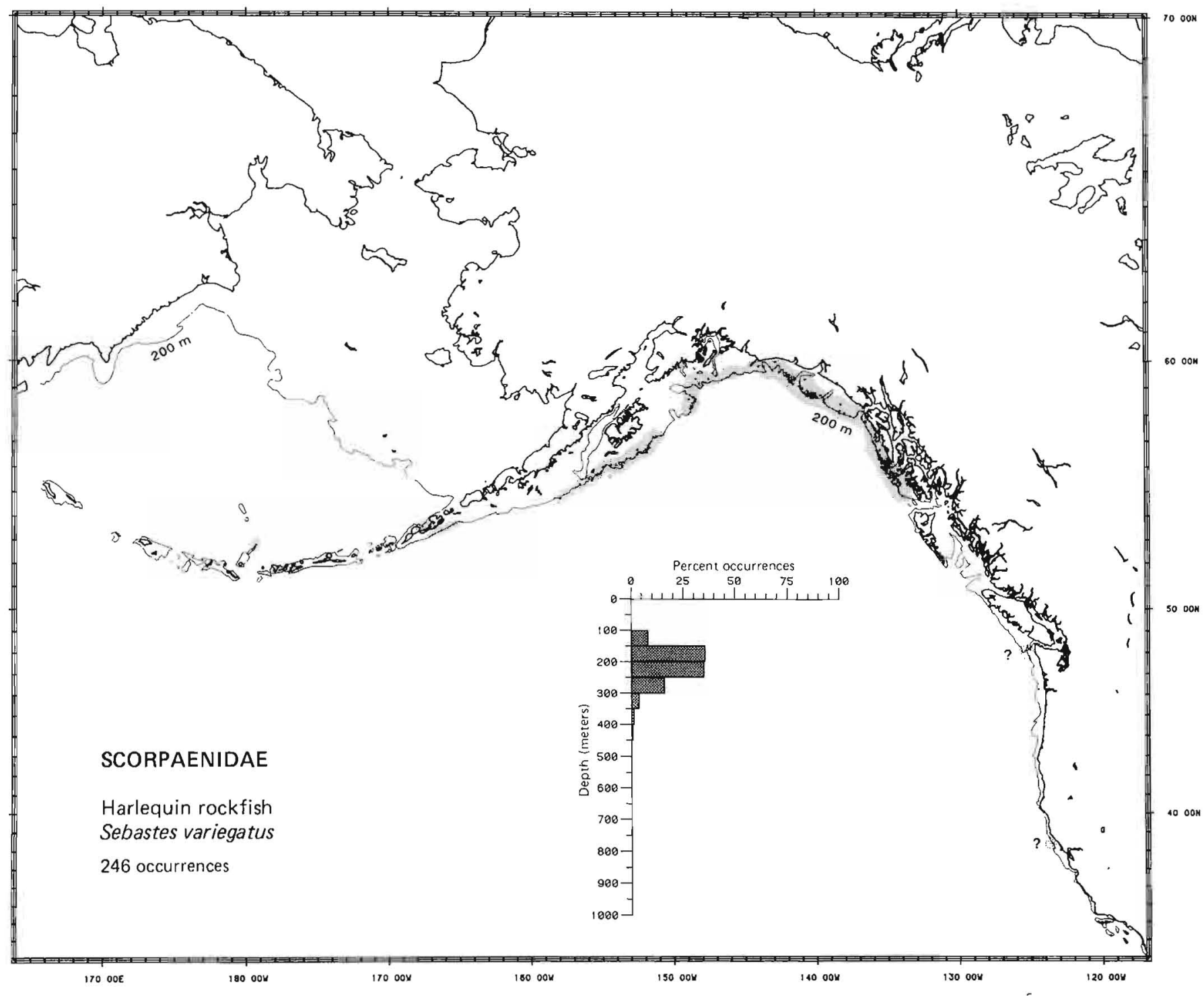


Literature Reported from Sanak Island in the Gulf of Alaska to San Diego, California (Hart 1973), from 91 to $320 \mathrm{~m}$ in depth (Eschmeyer and Herald 1983).

Survey data Found from Semisopochnoi Island in the Aleutian Islands to the Santa Barbara Channel, California. Depth range 25 to $475 \mathrm{~m}$, most frequently ( $36.3 \%$ of occurrences) on the upper slope between 200 and $250 \mathrm{~m}$, and $95.6 \%$ of occurrences from depths of 100 to $350 \mathrm{~m}$. Survey data extend the known range to the west and expand the known depth range.

\section{Conclusions}

Zoogeography Eastern boreal Pacific

Life zone Outer shelf-mesobenthal (mesobenthal)

Range From Semisopochnoi Island in the Aleutian Islands to San Diego, California

Depth 25 to $475 \mathrm{~m}$

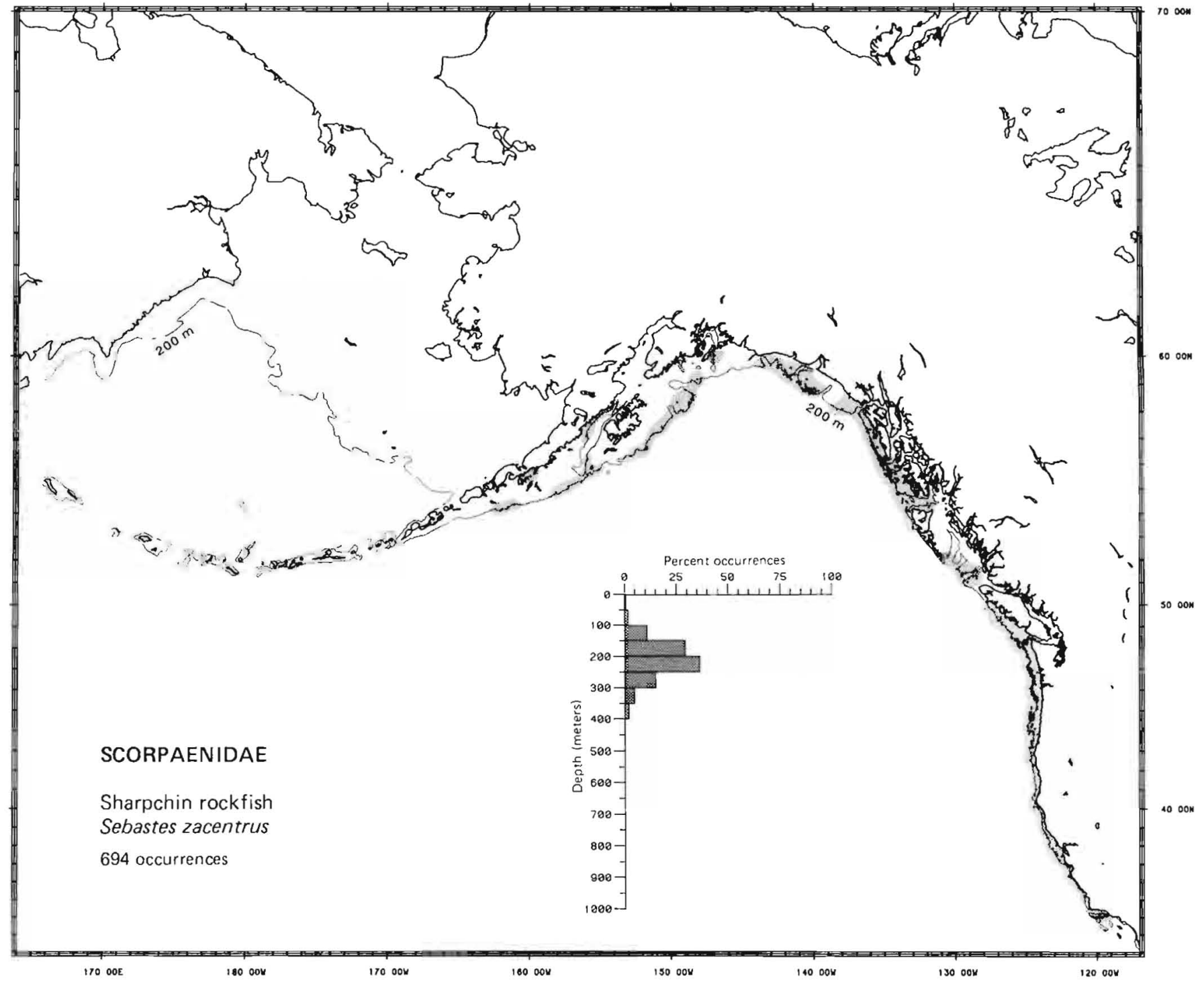


Literature Reported from the Sea of Okhotsk, the Bering Sea, and Amchitka Island in the Aleutian Islands to Cedros Island, Baja California (Miller and Lea 1972; Hart 1973; Simenstad et al. 1977), at depths of 20 to $1524 \mathrm{~m}$ (Howe 1981; Eschmeyer and Herald 1983).

Survey data Found from Medny Seamount and off Glubokaya Bay in the western Bering Sea, and from Navarin Canyon southeast along the slope of the eastern Bering Sea, west to Stalemate Bank and the Ulm Plateau in the Aleutian Islands. and southeast to off San Nicolas Island, California. May have been taken at shallow depths in the Gulf of Anadyr and Bristol Bay. Depth of capture ranged from 25 to $1275 \mathrm{~m}$, with $20.8 \%$ of occurrences on the upper slope between 200 and $250 \mathrm{~m}$, and $95.5 \%$ of occurrences from depths of 100 to $800 \mathrm{~m}$. Survey data provide a more precise distribution in the Bering Sea and extend the known range in the Aleutian Islands.

\section{Conclusions}

\section{Zoogeography Eastern boreal Pacific}

Life zone Outer shelf-bathybenthal (mesobenthal)

Range $\quad$ From the Sea of Okhotsk north to Navarin Canyon (and possibly the Anadyr Gulf) in the Bering Sea and from Stalemate Bank and Ulm Plateau in the Aleutian Islands southeast to Cedros Island, Baja California

Depth 20 to $1524 \mathrm{~m}$

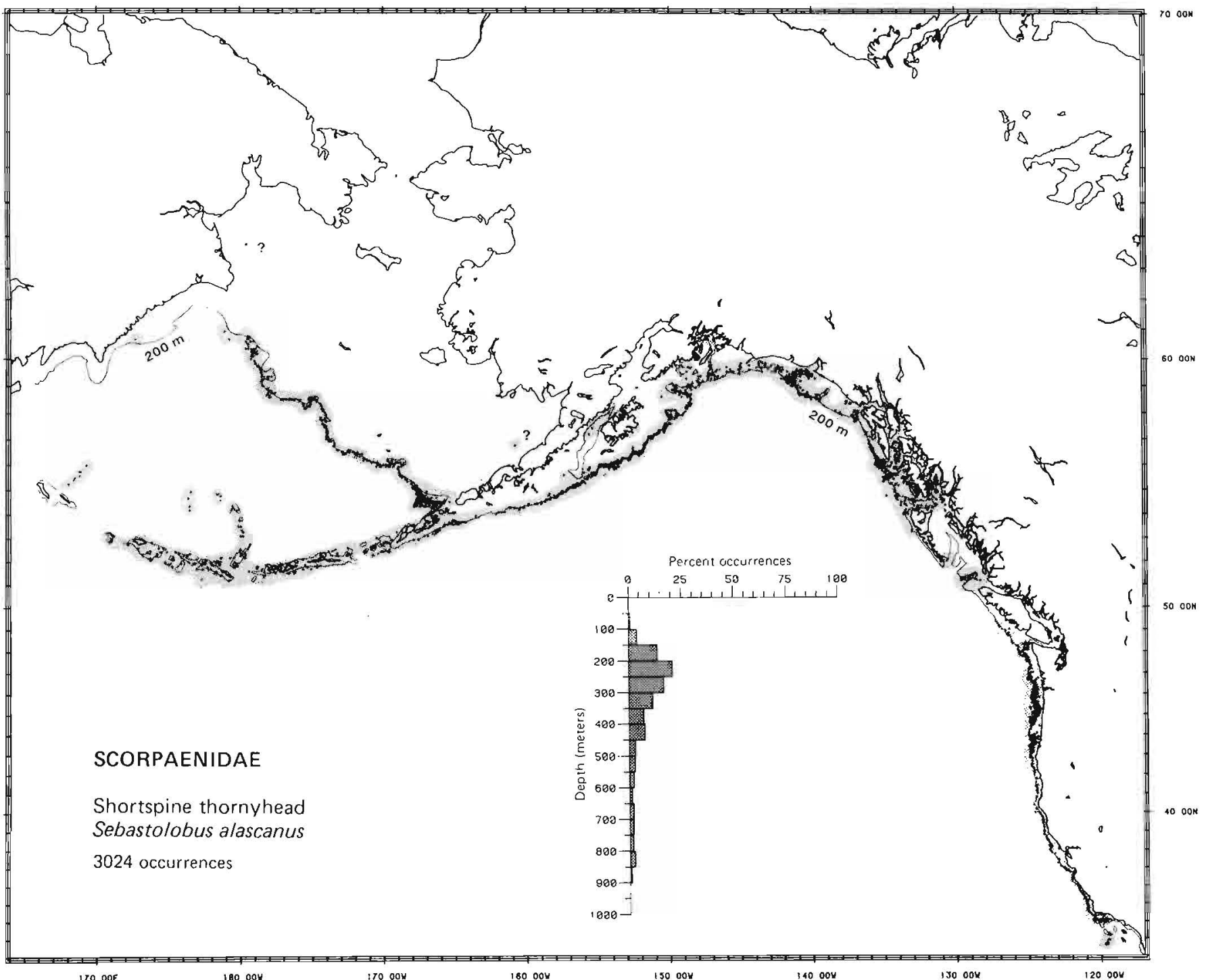


Literature Reported from east-central Honshu, Japan (but not in the Sea of Okhotsk), north to Cape Olyutorski in the Bering Sea, throughout the Aleutian Islands, and south to Cedros Island, Baja California (Shmidt 1950; Quast and Hall 1972; Hart 1973; Sasaki 1985). Only adults have been found in the western Pacific, suggesting that this region is not an important part of the range of the species (Sasaki 1985). Reported at depths of 0 to $2740 \mathrm{~m}$ (Howe 1981; McFarlane and Beamish 1983).

Survey data Found from Medny Seamount and off Glubokaya Bay north to off Cape Navarin, southeast along the outer shelf and slope of the eastern Bering Sea (and in an isolated area southeast of Saint Lawrence Island), west in the Aleutian Islands to Stalemate Bank and Ulm Plateau, and southeast to the Patton Escarpment off San Nicolas Island in southern California. Depth range 25 to $1325 \mathrm{~m}$, most frequently (22.2\% of occurrences) on the outer shelf from 100 to $150 \mathrm{~m}$, and $95.1 \%$ of occurrences from depths $<700 \mathrm{~m}$. Survey data provide a more precise northern limit in the Bering Sea. It should be noted that sablefish occur on a number of seamounts in the Aleutian Basin.

\section{Conclusions}

Zoogeography Eastern boreal Pacific

Life zone Inner shelf-bathybenthal (outer shelf)

Range From east-central Honshu, Japan, north to the Bering Sea (but not in the Sea of Okhotsk), southeast of Saint Lawrence Depth $\quad 0$ to $2740 \mathrm{~m}$

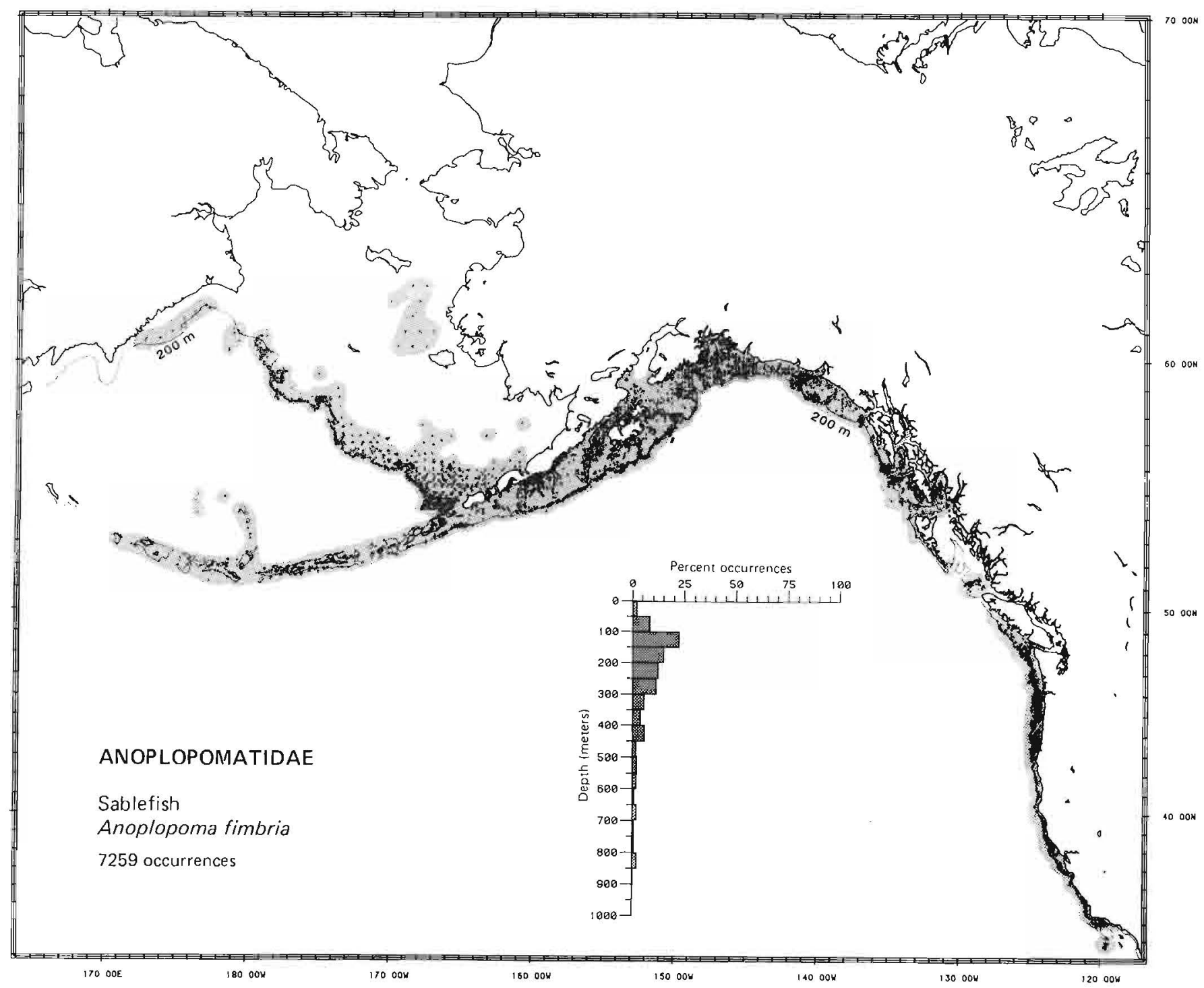


Literature Reported from Peter the Great Bay, U.S.S.R., in the Sea of Japan, north to the Chukchi Sea, and south to Oregon (Andriyashev 1954; Howe 1981), at depths of intertidal zone to $48 \mathrm{~m}$ (Rutenberg 1962; Howe 1981).

Survey data Occurred in catches from northeast of Cape Lisburne in the Chukchi Sea south along the Alaska coast of the eastern Bering Sea to Unimak Island in the Aleutian Islands and from there east to Cordova, Alaska, in the northern Gulf of Alaska. Depth range 25 to $475 \mathrm{~m}$, most frequently $(73.1 \%$ of occurrences) on the inner shelf between 0 and $50 \mathrm{~m}$, and $98.6 \%$ of occurrences from depths $<100 \mathrm{~m}$. Survey data provide a more precise northern limit in the Chukchi Sea and a new maximum depth record. However, the record at $475 \mathrm{~m}$ appears anomalous and may represent the capture of a pelagic juvenile from near the surface but above this depth. The next greatest depth of occurrence was at $175 \mathrm{~m}$.

\section{Conclusions}

Zoogeography Arctic-circumboreal Pacific

Life zone Inner shelf-middle shelf (inner shelf)

Range From Peter the Great Bay, U.S.S.R., in the Sea of Japan, to northeast of Cape Lisburne in the Chukchi Sea, west to Unimak Island in the Aleutian Islands, and Oregon

Depth Intertidal zone to $175 \mathrm{~m}$ (possibly to $475 \mathrm{~m}$ )

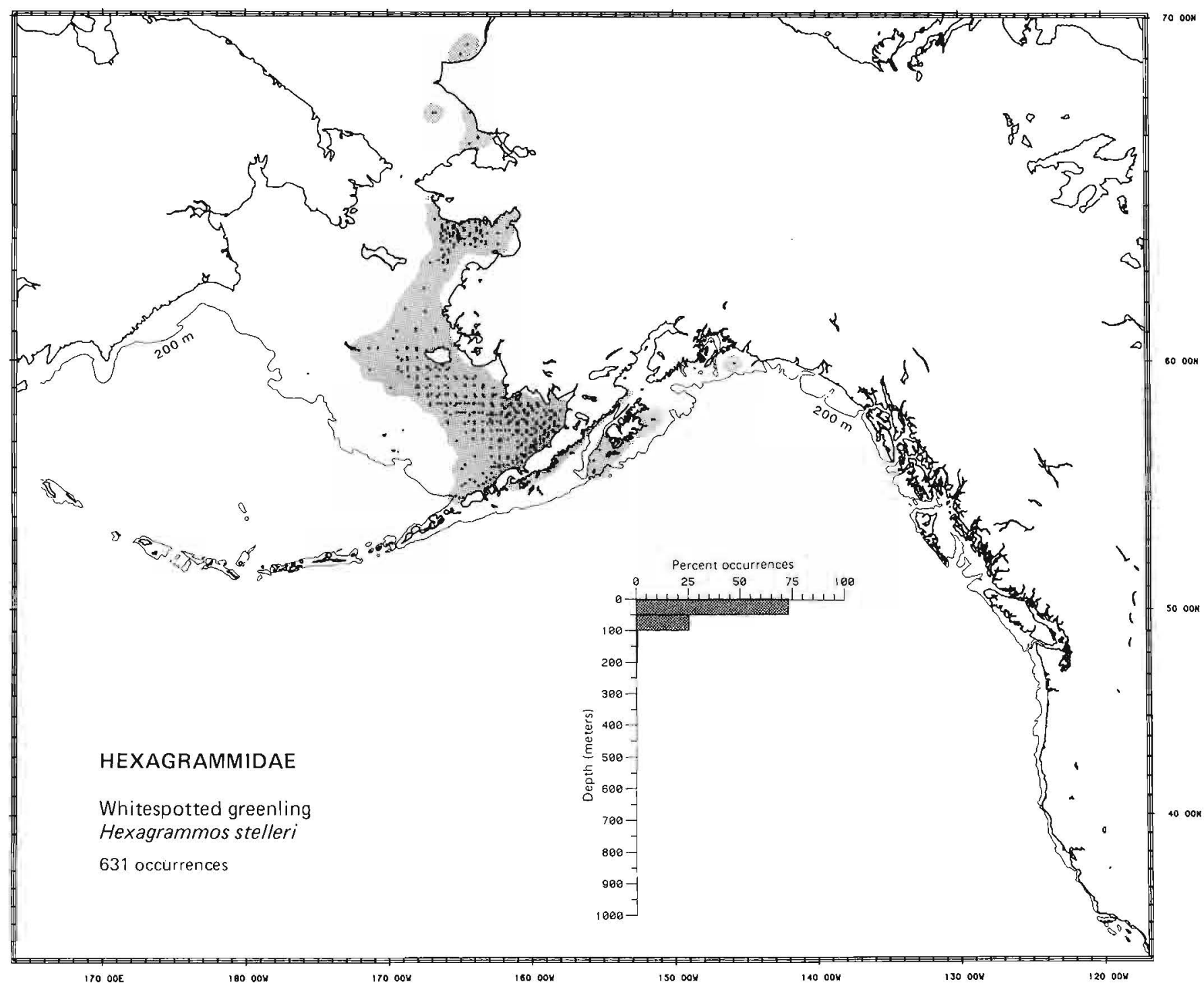


Literature Reported from the Shumagin Islands in the western Gulf of Alaska (and possibly the Bering Sea) to Ensenada, Baja California (Quast and Hall 1972; Hart 1973), and in depth from the intertidal zone to $427 \mathrm{~m}$ (Howe 1981; Garrison and Miller 1982; Eschmeyer and Herald 1983).

Survey data Found from southwest of Chirikof Island (south of Shelikof Strait) in the Gulf of Alaska to Santa Cruz Island, California. Depth range 25 to $475 \mathrm{~m}$, most frequently (31.1\% of occurrences) on the outer shelf between 100 and $150 \mathrm{~m}$, and $98.3 \%$ of occurrences from depths $<300 \mathrm{~m}$. Survey data provide a new maximum depth record.

\section{Conclusions}

Zoogeography Eastern boreal Pacific

Life zone Estuarine-mesobenthal (outer shelf)

Range $\quad$ From the Shumagin Islands in the western Gulf of Alaska (possibly the Bering Sea) to Ensenada, Baja California

Depth Intertidal zone to $475 \mathrm{~m}$

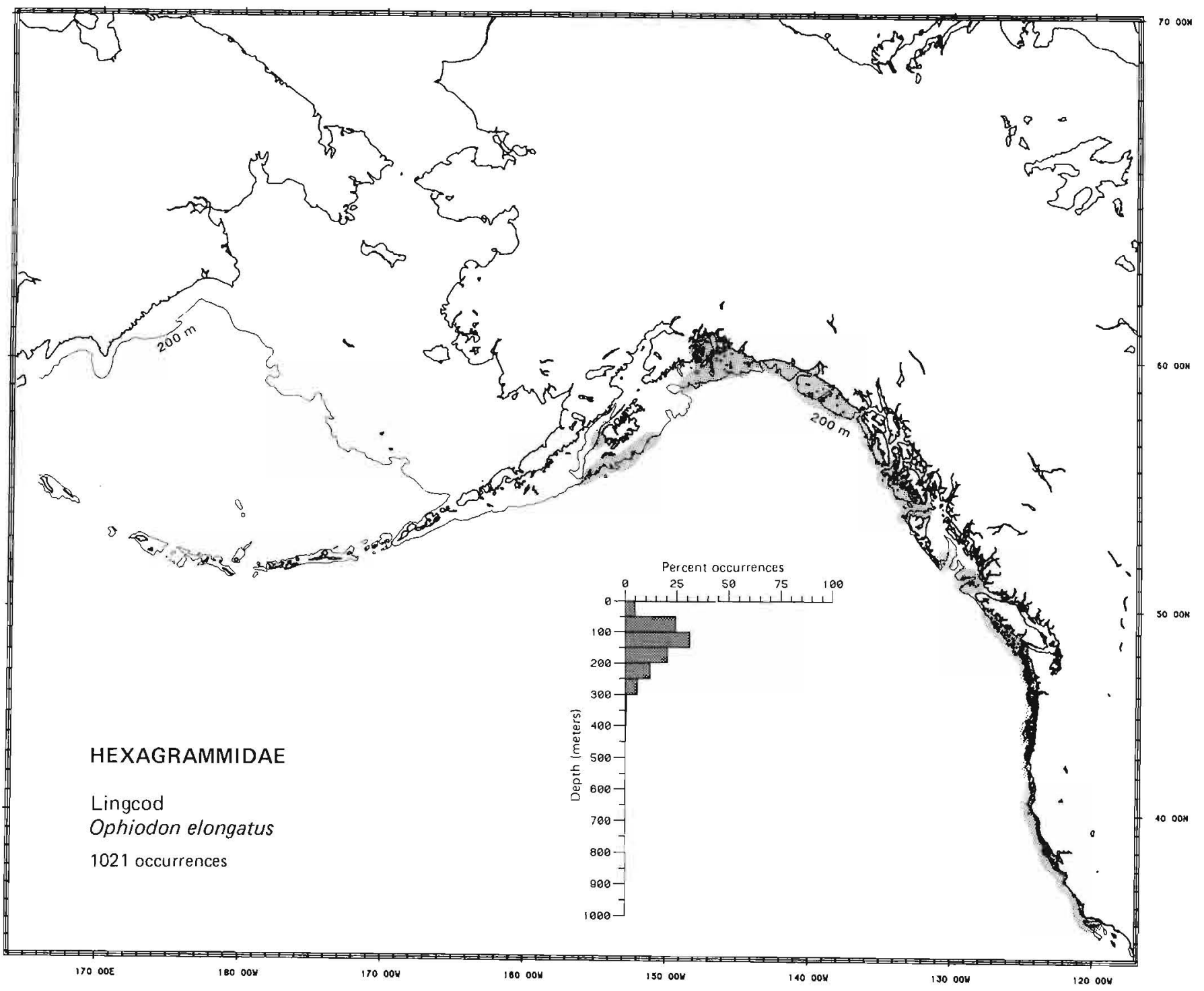


Literature Reported from the Yellow Sea to Cape Olyutorski in the Bering Sea and along the Commander and Aleutian Islands to Redondo Beach, California (Rutenberg 1962; Okada and Kobayashi 1968; Eschmeyer and Herald 1983). It is rare south of Alaska (Rutenberg 1962). In depth, reported from the lower intertidal zone to $250 \mathrm{~m}$ (Rutenberg 1962; Fedorov 1973a).

Survey data Found from Cape Olyutorski in the western Bering Sea north to northeast of Cape Navarin, southeast along the outer shelf and slope of the eastern Bering Sea to Bristol Bay, west in the Aleutian Islands to Stalemate Bank and Bowers Bank, and east to Icy Bay in the northern Gulf of Alaska. Depth range 25 to $575 \mathrm{~m}$, most frequently $(35.6 \%$ of occurrences) on the outer shelf between 100 and $150 \mathrm{~m}$, and $96.5 \%$ of occurrences from depths $\leqslant 300 \mathrm{~m}$. Survey data provide a more precise northern limit in the Bering Sea and a new maximum depth record.

\section{Conclusions}

Zoogeography Northwestern boreal Pacific

Life zone Inner shelf-mesobenthal (outer shelf)

Range From the Yellow Sea to Cape Navarin in the Bering Sea and from Stalemate Bank and Bowers Bank in the Aleutian Islands to Icy Bay, Alaska, rarely to Redondo Beach, California

Depth Lower intertidal zone to $575 \mathrm{~m}$

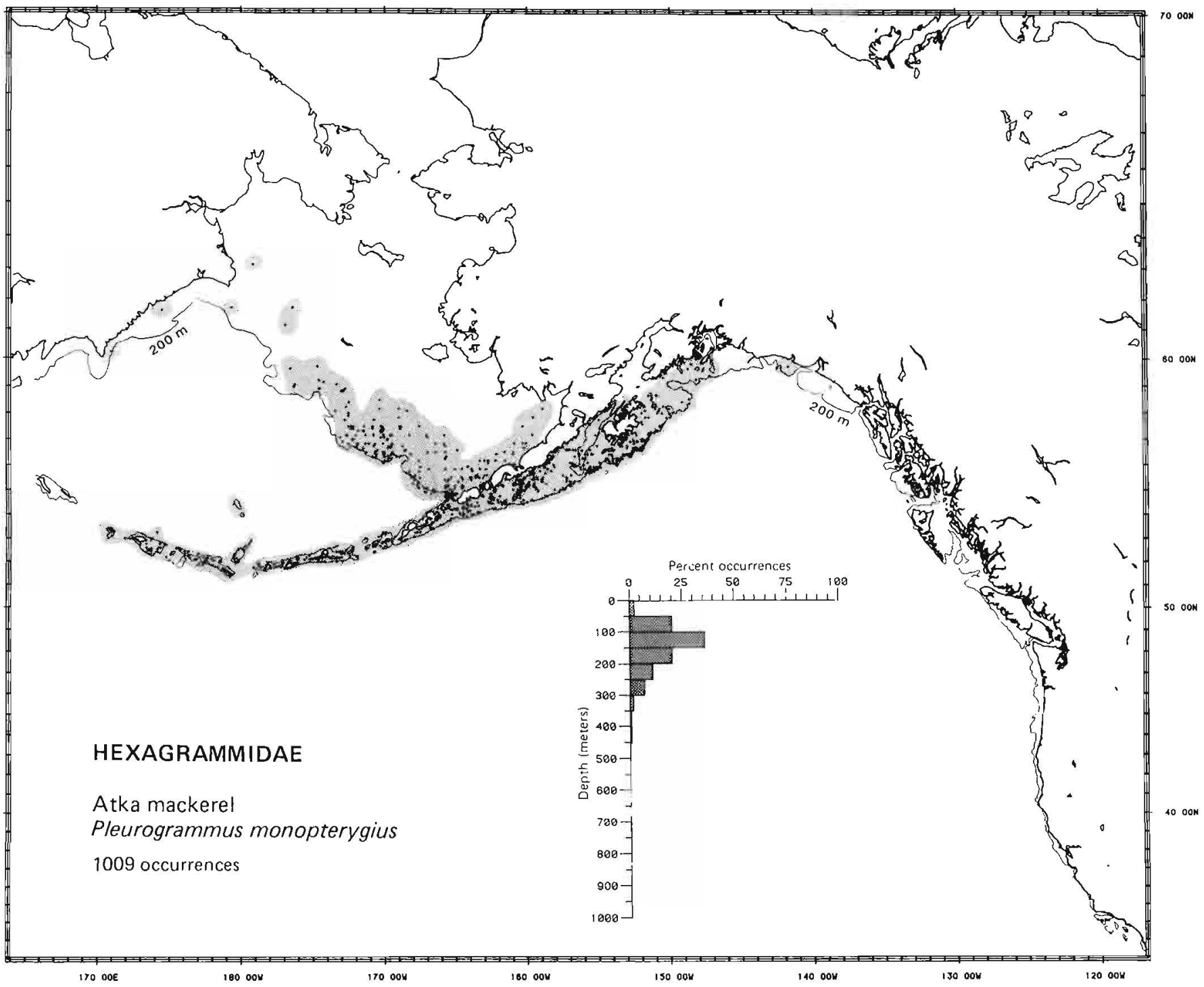


Literature Reported from Pusan, South Korea, to the Anadyr Gulf in the Bering Sea (outside the Sea of Okhotsk), throughout the Commander and Aleutian Islands, and southeast to Mathieson Channel, British Columbia (Shmidt 1950; Wilimovsky 1964; Ueno 1970; Quast and Hall 1972; Hart 1973), at depths of 0 to $1500 \mathrm{~m}$ (Fedorov 1973a).

Survey data Found from southwest of Providence Bay on the Chukchi Peninsula to Attu Island in the Aleutian Islands, occurring primarily over the outer shelf and slope of the eastern Bering Sea and pelagically across the Aleutian Basin, and from the Aleutian Islands east to Baranof Island in southeastern Alaska. Depth range 25 to $975 \mathrm{~m}$, most frequently (18.5\% of occurrences) between 50 and $100 \mathrm{~m}$, and $97.2 \%$ of occurrences from depths $<850 \mathrm{~m}$. Survey data show a distinct midwater distribution of this species across the Aleutian Basin. Since the species appears to occur pelagically with a modal depth of occurrence at $75 \mathrm{~m}$, trawls made at greater depths may have actually captured the species nearer the surface than at the depth of tow.

\section{Conclusions}

Zoogeography Kurile-Aleutian

Life zone Neritic-mesopelagic (neritic)

Range $\quad$ From Pusan, South Korea, north (outside the Sea of Okhotsk) to Providence Bay in the Anadyr Gulf of the Bering Depth $\quad 0$ to $1500 \mathrm{~m}$

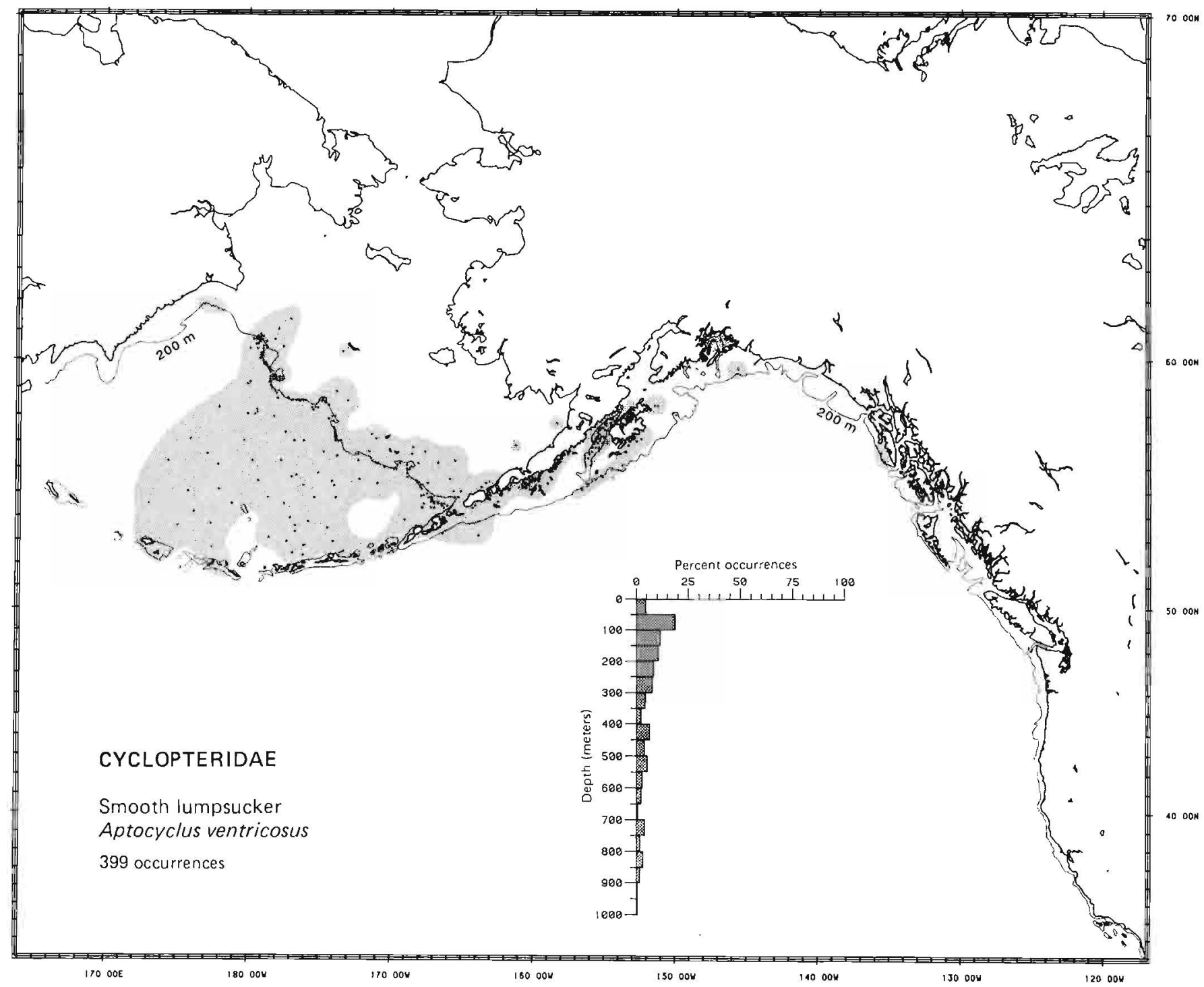


Taxonomic comment This complex may include four species that have been called "blacktail snailfish" in the field, including the following: Alaska snailfish, Careproctus colletti Gilbert 1896; blackfinned snailfish, C. cypselurus(Jordan and Gilbert 1898 in Jordan and Evermann); forktail snailfish, C. furcellus Gilbert and Burke 1912; and the blacktail snailfish, C. melanurus Gilbert 1892. Good field characters for distinguishing these species have not been established.

Literature The Alaska snailfish ranges from the Sea of Japan to the Bering Sea and from there to the slope south of the Alaska Peninsula at depths of 510 to $1350 \mathrm{~m}$ (Quast and Hall 1972; Fedorov 1973a; Baxter 1985). The blackfinned snailfish occurs from Sakhalin, U.S.S.R., to the Bering Sea and from there to Oregon at depths of 640 to $1775 \mathrm{~m}$ (Shmidt 1950; Quast and Hall 1972; Fedorov 1973a). The forktail snailfish is found from Sakhalin to the Bering Sea at 98 to $882 \mathrm{~m}$ (Shmidt 1950; Quast and Hall 1972; Fedorov 1973a; Baxter 1985). The blacktail snailfish has been reported from the Bering Sea and Unalaska Island to San Diego at 89 to $2286 \mathrm{~m}$ (Miller and Lea 1972 ; Quast and Hall 1972; Howe 1981; Eschmeyer and Herald 1983).

Survey data The "blacktail smailfish" complex was found from south of Cape Navarin southeast along the slope of the eastern Bering Sea to Akutan Island, west in the Aleutian Islands to Kiska Island, and southeast to Santa Barbara, California, at depths of 25 to $725 \mathrm{~m}$, most frequently (29.6\% of occurrences) on the upper middle slope between 400 and $500 \mathrm{~m}$, and $94.5 \%$ of occurrences from depths of 50 to $650 \mathrm{~m}$. Survey data for this complex of species cannot be used to describe range limits. The data, however, do define the distribution of the complex in the Bering Sea and may be of use to future taxonomic and ecological studies. It is not certain which species is dominant in the Bering Sea although it may be the blackfinned snailfish (Kessler 1985). Most records south of Oregon probably refer to the blacktail snailfish.

Conclusions The "blacktail snailfish" complex probably consists of at least four boreal Pacific, sublittoral and bathyal species that need to be accurately identified in field collections before any conclusion concerning the distribution of individual species can be reached.

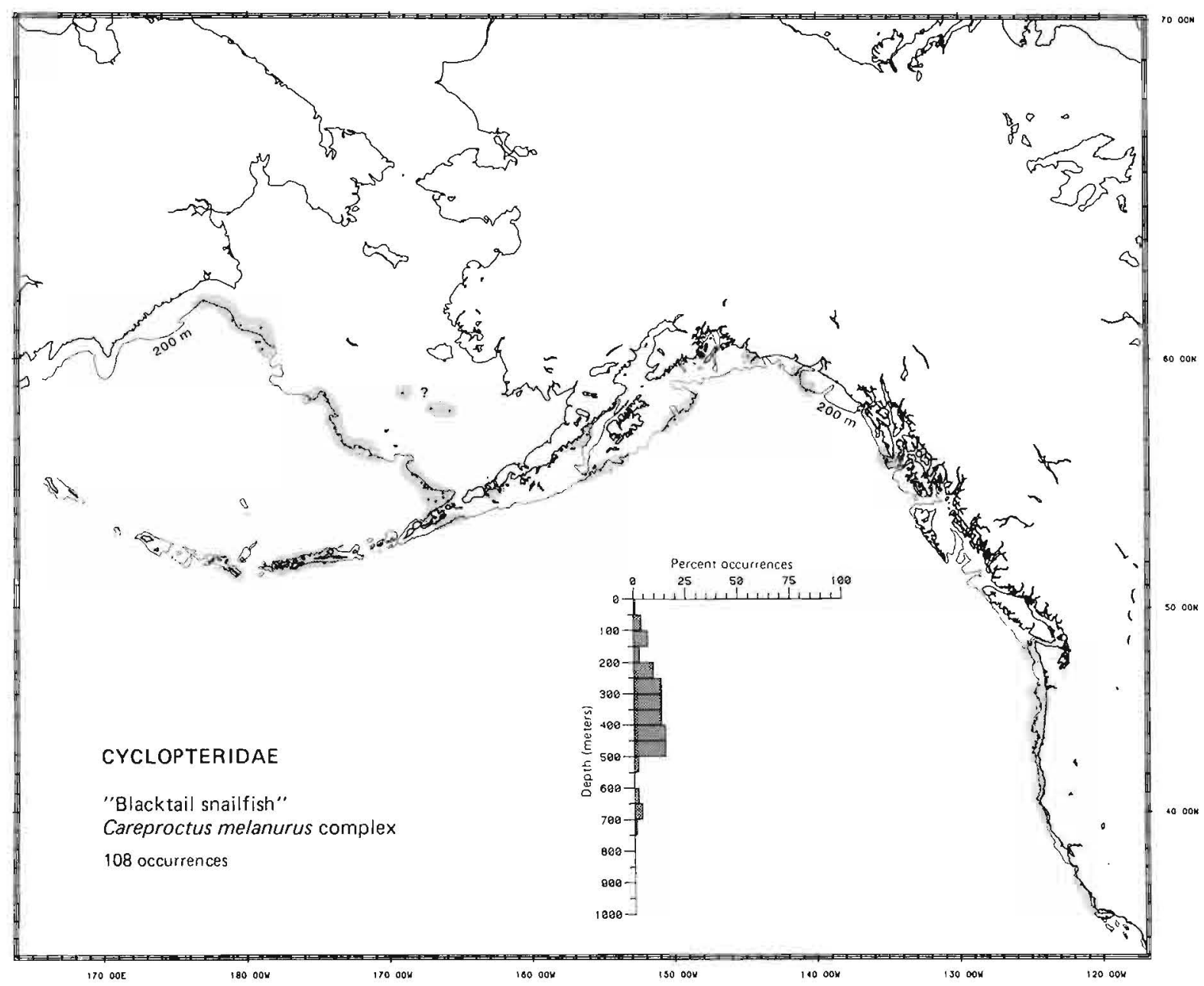


Taxonomic comment This complex may include four or more species that have been called "pink snailfish" in the field, including the following: pink snailfish, Careproctus osborni (Townsend and Nichols 1925); monster snailfish, C. phasma Gilbert 1896; salmon snailfish, C. rastrinus Gilbert and Burke 1912; and peachskin snailfish, C. scottae Chapman and DeLacy 1939. Good field characters for distinguishing these species have not been established.

Literature The salmon snailfish ranges from Sakhalin, U.S.S.R., in the Sea of Okhotsk to the Bering Sea and from there to southeast Alaska at depths of 116 to $640 \mathrm{~m}$ (Quast and Hall 1972; Fedorov 1973a). The monster snailfish occurs from western Kamchatka to Bristol Bay and west in the Aleutian Islands to Amchitka Island at 84 to $504 \mathrm{~m}$ (Shmidt 1950; Simenstad et al. 1977). The peachskin snailfish is found from the western Bering Sea to southeast Alaska with a known depth of occurrence at $183 \mathrm{~m}$ (Chapman and DeLacy 1934; Baxter 1985; Kessler 1985). The pink snailfish occurs off central and southern California at $805 \mathrm{~m}$ (Townsend and Nichols 1925; Howe 1981).

Survey data The "pink snailfish" complex was found from Saint Lawrence Island in the eastern Bering Sea to Navarin Canyon and southeast along the outer shelf and slope to Unimak Island, west in the Aleutian Islands to Attu Island, and southeast to San Francisco Bay, California, at depths of 25 to $825 \mathrm{~m}$, most frequently (42.4\% of occurrences) on the outer shelf between 100 and $150 \mathrm{~m}$, and $95.6 \%$ of occurrences from depths of 50 to $400 \mathrm{~m}$. Survey data for this complex of species cannot be used to describe range limits, although they do define the distribution of the complex in the Bering Sea and may be of use to future taxonomic and ecological studies. The salmon snailfish is probably the most abundant species in the Bering Sea and the data presented here primarily describe the distribution of that species. However, records from California probably are those of the pink snailfish.

Conclusions The "pink snailfish" complex probably consists of at least four boreal Pacific, sublittoral and bathyal species that need to be accurately identified in field collections before any conclusion concerning the distribution of the individual species can be reached.

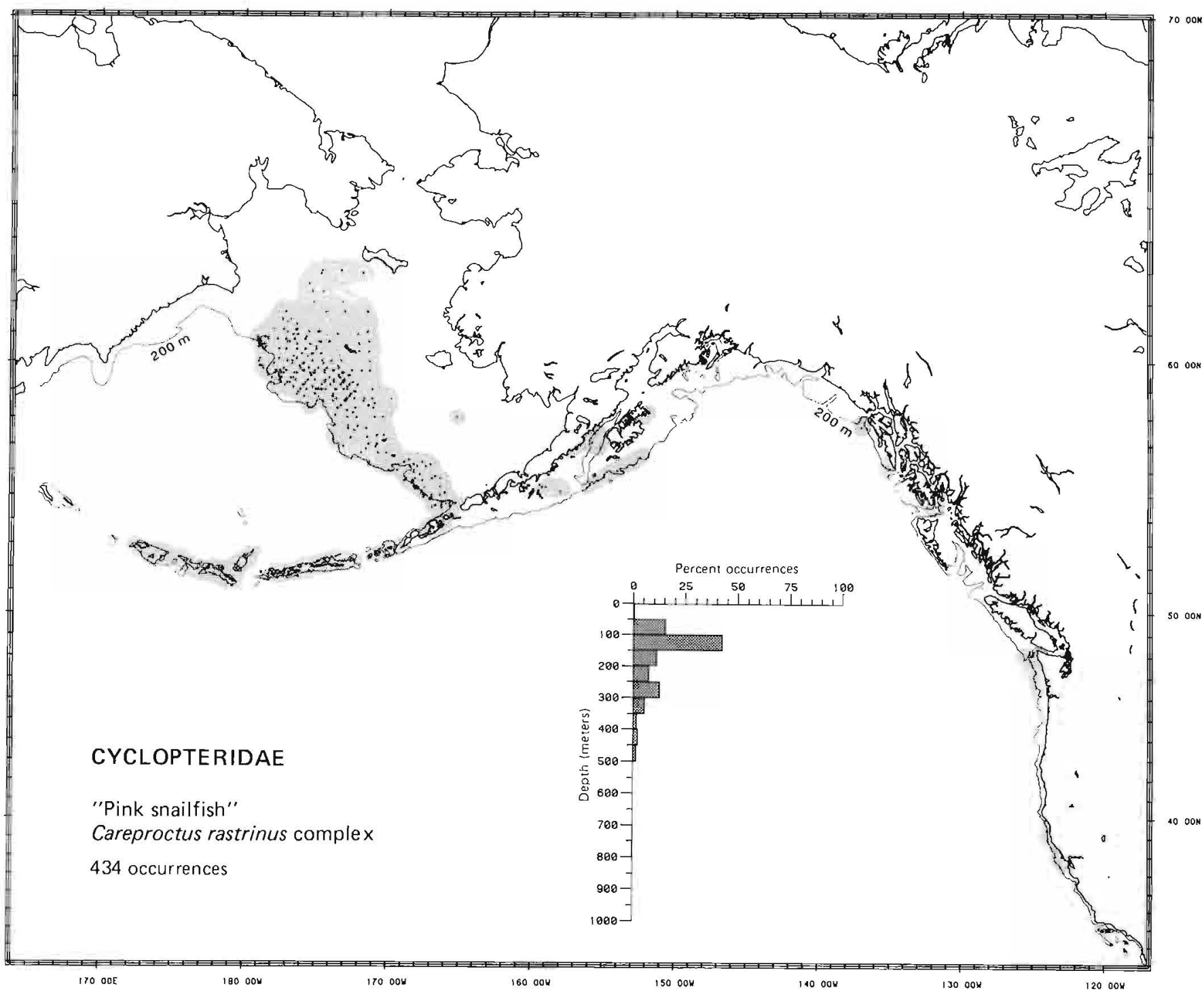


(Günther 1896)

Literature Reported from Muroran, Hokkaido, Japan, and the Sea of Okhotsk to the Chukchi Sea, occurring west along the Aleutian Islands to Amchitka Island and east to Puget Sound, Washington (Ueno 1970; Quast and Hall 1972; Simenstad et al. 1977; Eschmeyer and Herald 1983), at depths of 0 to $240 \mathrm{~m}$ (Fedorov 1973a; Eschmeyer and Herald 1983).

Survey data Found from off Cape Nizkiy (on the Korak Coast of the western Bering Sea) to the Bering Strait, south in the eastern Bering Sea to the Alaska Peninsula and Unimak Island, west in the Aleutian Islands to Peterel Bank, and east to South Baranof Island in southeastern Alaska. Depth range 25 to $575 \mathrm{~m}$, most frequently $157.1 \%$ of occurrences) on the middle shelf between 50 and $100 \mathrm{~m}$, and $96.1 \%$ of occurrences from depths $<200 \mathrm{~m}$. Survey data provide a new maximum depth record.

\section{Conclusions}

Zoogeography Arctic-northern boreal Pacific

Life zone Inner shelf-outer shelf (middle shelf)

Range From Muroran, Hokkaido, Japan, and the Sea of Okhotsk, Amchitka Island in the Aleutian Islands, and Puget Sound,

Depth $\quad 0$ to $575 \mathrm{~m}$

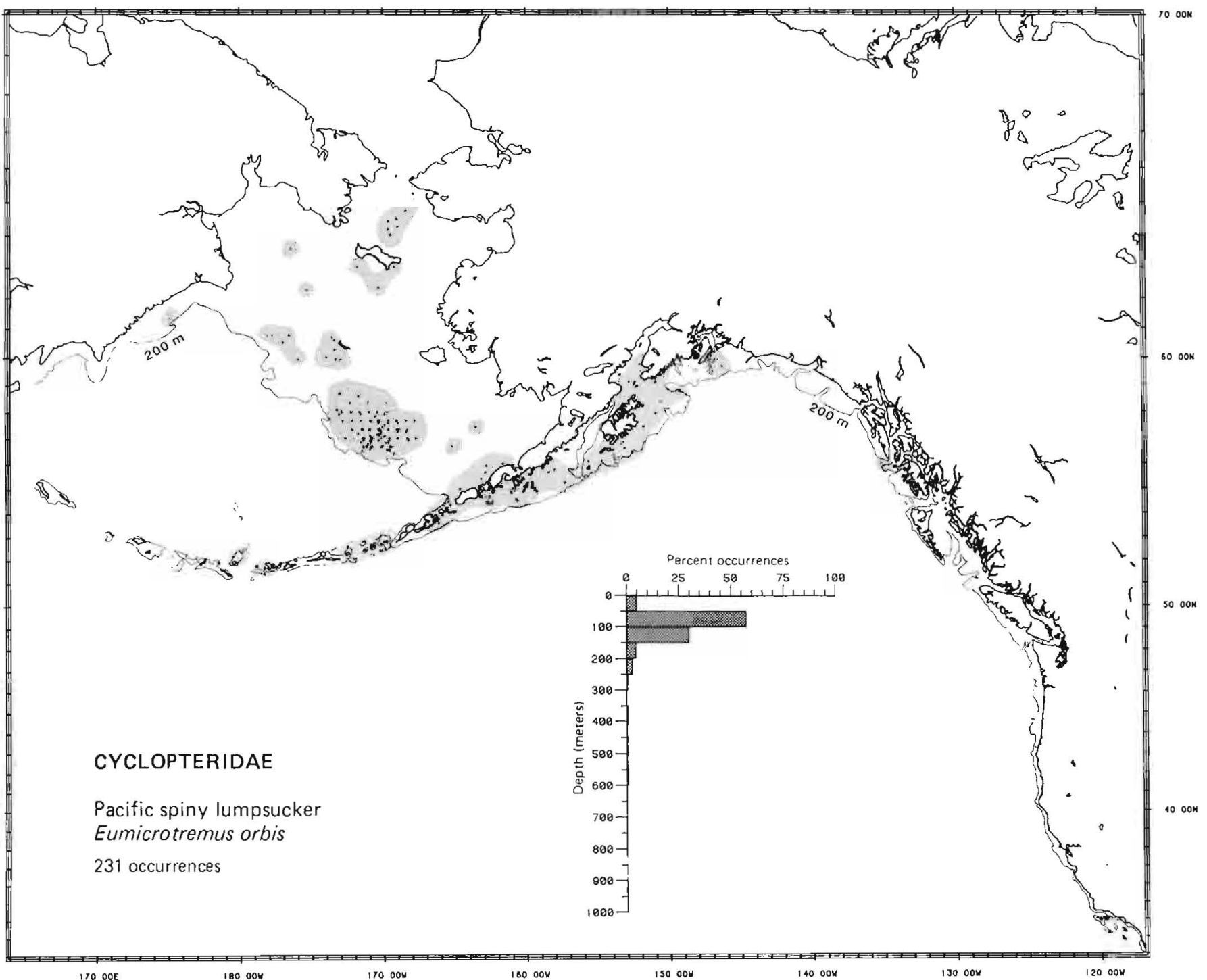


Literature Reported from Avacha Bay in southeastern Kamchatka to southeastern Alaska, west to Unalaska Island, north along the Alaskan coast of the Bering Sea, across the Canadian Arctic and south in the North Atlantic to Nova Scotia (Able and McAllister 1980), at depths of 25 to $366 \mathrm{~m}$ (Able and McAllister 1980; Eschmeyer and Herald 1983).

Survey data Found from onshore of Navarin Canyon in the eastern Bering Sea, southeast to the Alaska Peninsula and off Akutan Island, and east in the Gulf of Alaska to southeast of Kodiak Island. Depth range 25 to $275 \mathrm{~m}$, most frequently (59.1\% of occurrences) on the middle shelf between 50 and $100 \mathrm{~m}$, and $94.9 \%$ of occurrences from depths $\leqslant 150 \mathrm{~m}$. Survey data do not extend the known range, either geographically or in depth. All records plotted here were recorded in the field as the marbled snailfish, Liparis dennyi Jordan and Starks 1895. However, all Liparis taken in the eastern Bering Sea during 1983 proved to be dusky snailfish; hence, it is assumed that most records for marbled snailfish were probably records of dusky snailfish.

\section{Conclusions}

Zoogeography Arctic-western boreal Atlantic

Life zone Inner shelf-outer shelf (middle shelf)

Ranges From Avacha Bay in southeastern Kamchatka, Unalaska Island in the Aleutian Islands, and southeastern Alaska north along the Canadian Arctic to Nova Scotia in the western North Atlantic

Depth 25 to $366 \mathrm{~m}$

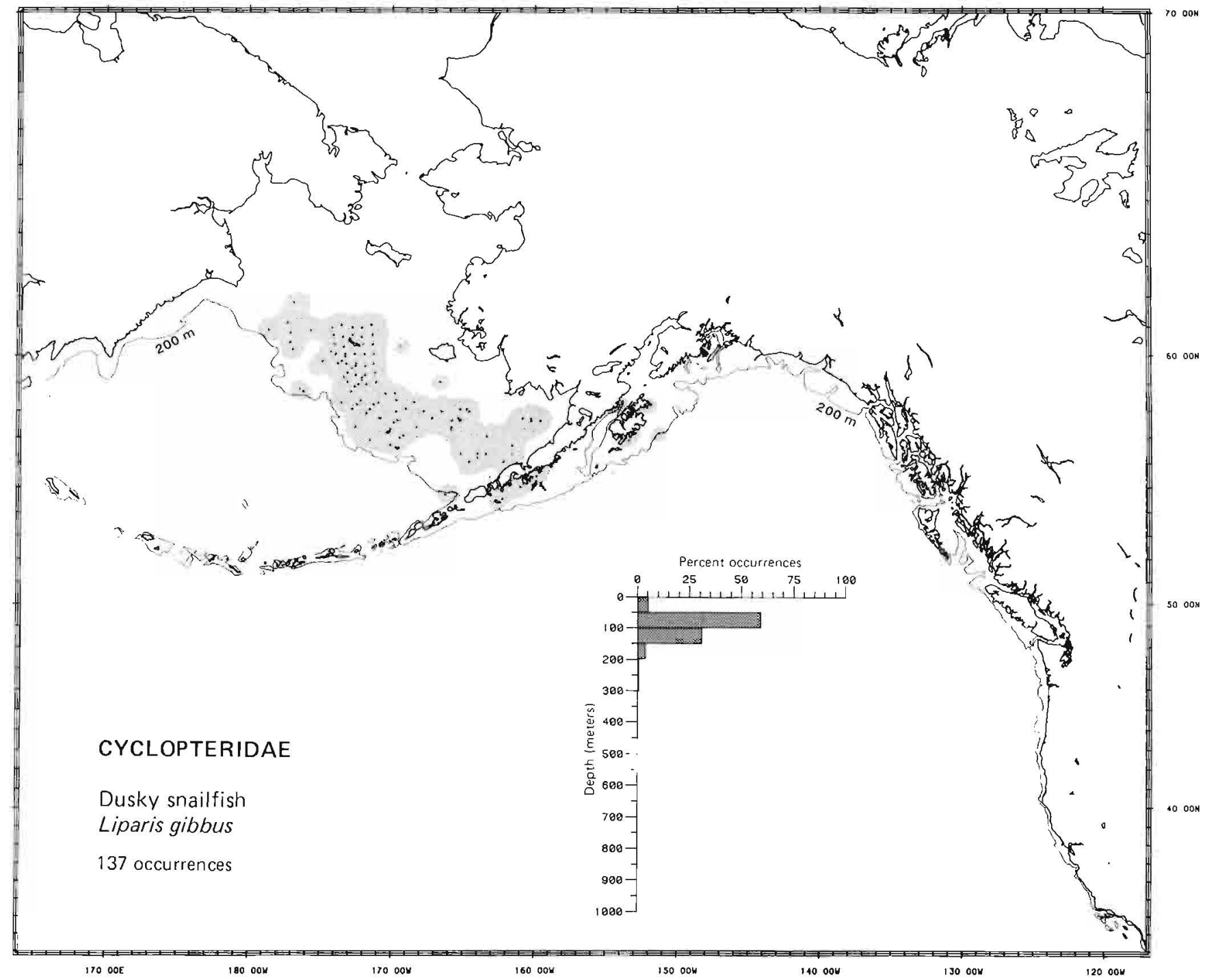


Literature Reported from the Tatar Strait and Honshu in the Sea of Japan and the Sea of Okhotsk to the Bering Sea and from Unalaska lsland in the Aleutian Islands southeast to Washington (Wilimovsky 1964; Okada and Kobayashi 1968; Quast and Hall 1972; Eschmeyer and Herald 1983), at depths of 18 to $750 \mathrm{~m}$ (Fedorov 1973a; Eschmeyer and Herald 1983).

Survey data Found from Navarin Canyon on the northwestern slope of the eastern Bering Sea and from Attu Island in the Aleutian Islands east to Dall Island in southeast Alaska. Depth range 25 to $825 \mathrm{~m}$, most frequently (53.8\% of occurrences) on the outer shelf from 100 to $150 \mathrm{~m}$, and $96.7 \%$ of occurrences from depths of 50 to $450 \mathrm{~m}$. Survey data provide a more precise northern limit in the Bering Sea, extend the known range westward in the Aleutian Islands, and provide a new maximum depth record.

\section{Conclusions}

Zoogeography Northern boreal Pacific

Life zone Middle shelf-mesobenthal (outer shelf)

Range From the Sea of Japan off Honshu to Navarin Canyon in the Bering Sea, west to Attu Island in the Aleutian Islands,

Depth 18 to $825 \mathrm{~m}$

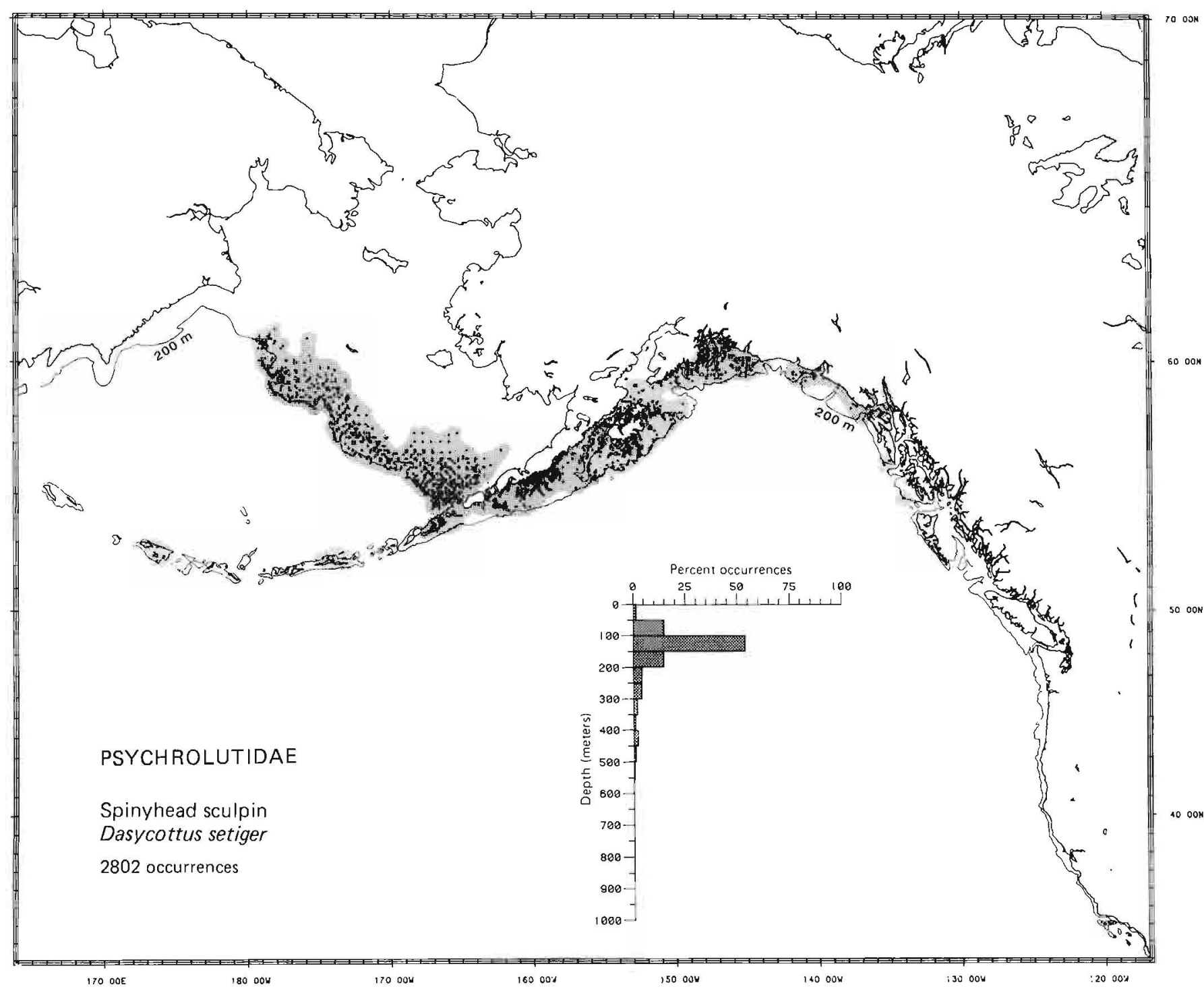


Literature Reported from Hokkaido, Japan, and the Sea of Okhotsk north to the southern Bering Sea, west in the Aleutian Islands to Amchitka Island, and east to Puget Sound, Washington (Shmidt 1950; Quast and Hall 1972; Simenstad et al. 1977; Eschmeyer and Herald 1983), at depths of 27 to $275 \mathrm{~m}$ (Eschmeyer and Herald 1983).

Survey data Found from off Natalii Bay (on the Korak Coast of the western Bering Sea) north to Cape Navarin, southeast along the outer shelf and slope of the eastern Bering Sea to Unimak Island, west in the Aleutian Islands to Stalemate Bank and Bowers Bank, and east from the Aleutian Islands to north of Graham Island, British Columbia. Depth range 75 to $1025 \mathrm{~m}$, most frequently (36.8\% of occurrences) on the mesobenthal slope between 200 and $300 \mathrm{~m}$, and $96.2 \%$ of occurrences from depths of 100 to $650 \mathrm{~m}$. This species is very similar to the darkfin sculpin, Malacocottus zonurus. Because of the available identification aids, many records of this species, particularly in the Bering Sea, may actually be records of the darkfin sculpin. Ignoring this possible source of error, the survey data extend the known range northward in the Bering Sea and westward in the Aleutian Islands, and provide a new maximum depth record.

\section{Conclusions}

Zoogeography Kurile-Aleutian

Life zone Outer shelf-bathybenthal (mesobenthal)

Range From Hokkaido, Japan, and the Sea of Okhotsk north to Cape Navarin in the Bering Sea, west in the Aleutian Islands Depth $\quad 27$ to $1025 \mathrm{~m}$

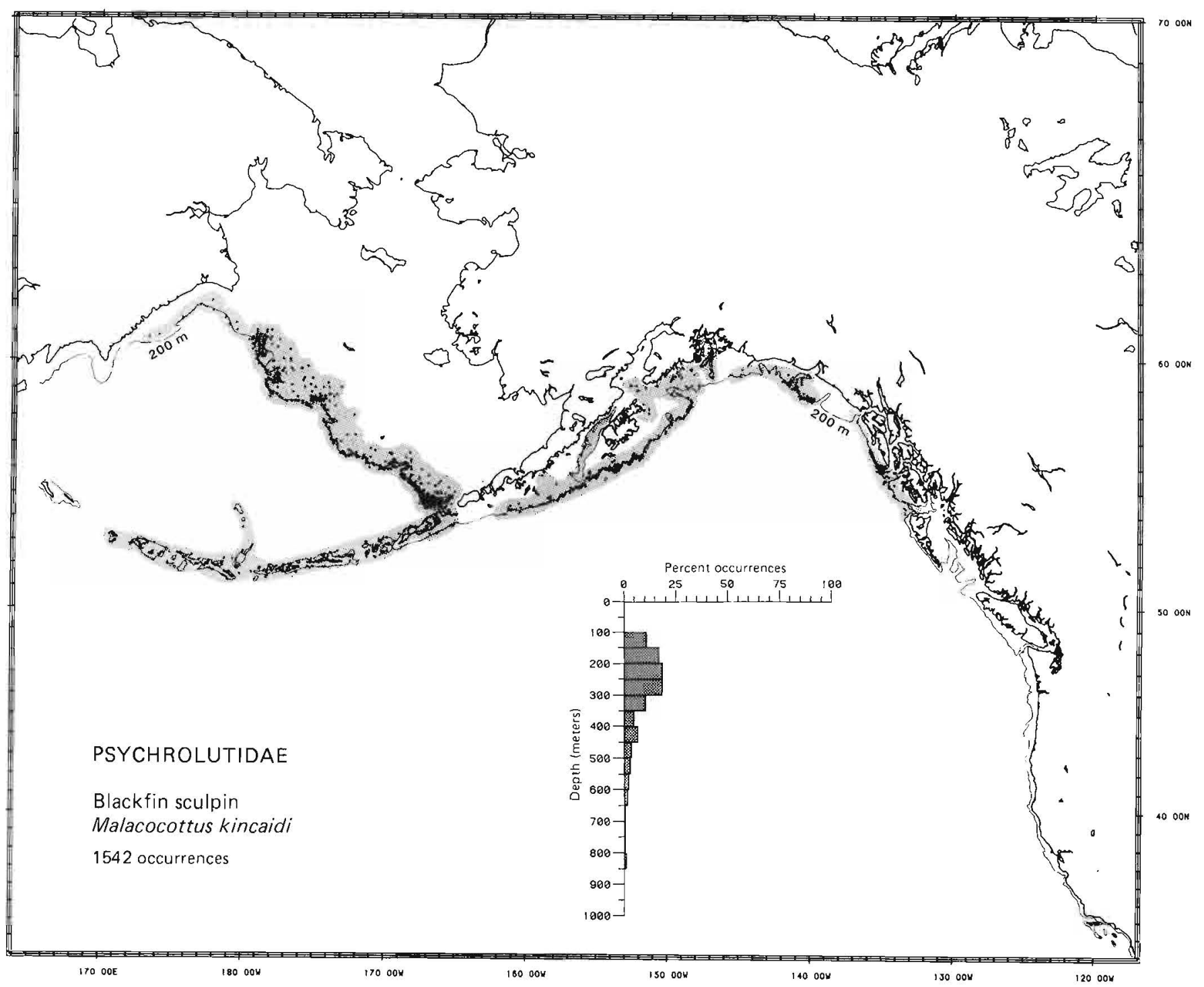


Literature Reported from the Sea of Okhotsk and the Bering Sea to Washington (Shmidt 1950; Howe 1981), at depths of 100 to $1980 \mathrm{~m}$ (Fedorov 1973a).

Survey data Found from off Glubokaya Bay (on the Korak Coast of the western Bering Sea) north to southeast of Cape Navarin, southeast along the outer shelf and slope of the eastern Bering Sea to Akutan Island, west in the Aleutian Islands to Agattu Island, and east to South Albatross Bank off Kodiak Island, Alaska. Depth range 75 to $875 \mathrm{~m}$, most frequently (23.6\% of occurrences) on the mesobenthal slope between 250 and $300 \mathrm{~m}$, and $95.0 \%$ of occurrences from depths of 100 to $650 \mathrm{~m}$. Survey data provide a more precise distribution of this species in the Bering Sea, extend its known range west in the Aleutian Islands, and provide a new minimum depth record. Because of its similarity to the blackfin sculpin, Malacocottus kincaidi, some records of the darkfin sculpin may be concealed in the distribution of the blackfin sculpin.

\section{Conclusions}

Zoogeography Northern boreal Pacific

Life zone Outer shelf-bathybenthal (mesobenthal)

Range $\quad$ From the Sea of Okhotsk to Cape Navarin in the western Bering Sea, southeast to Akutan Island, west in the Aleutian Islands to Agattu Island, and southeast to Washington

Depth 75 to $1980 \mathrm{~m}$

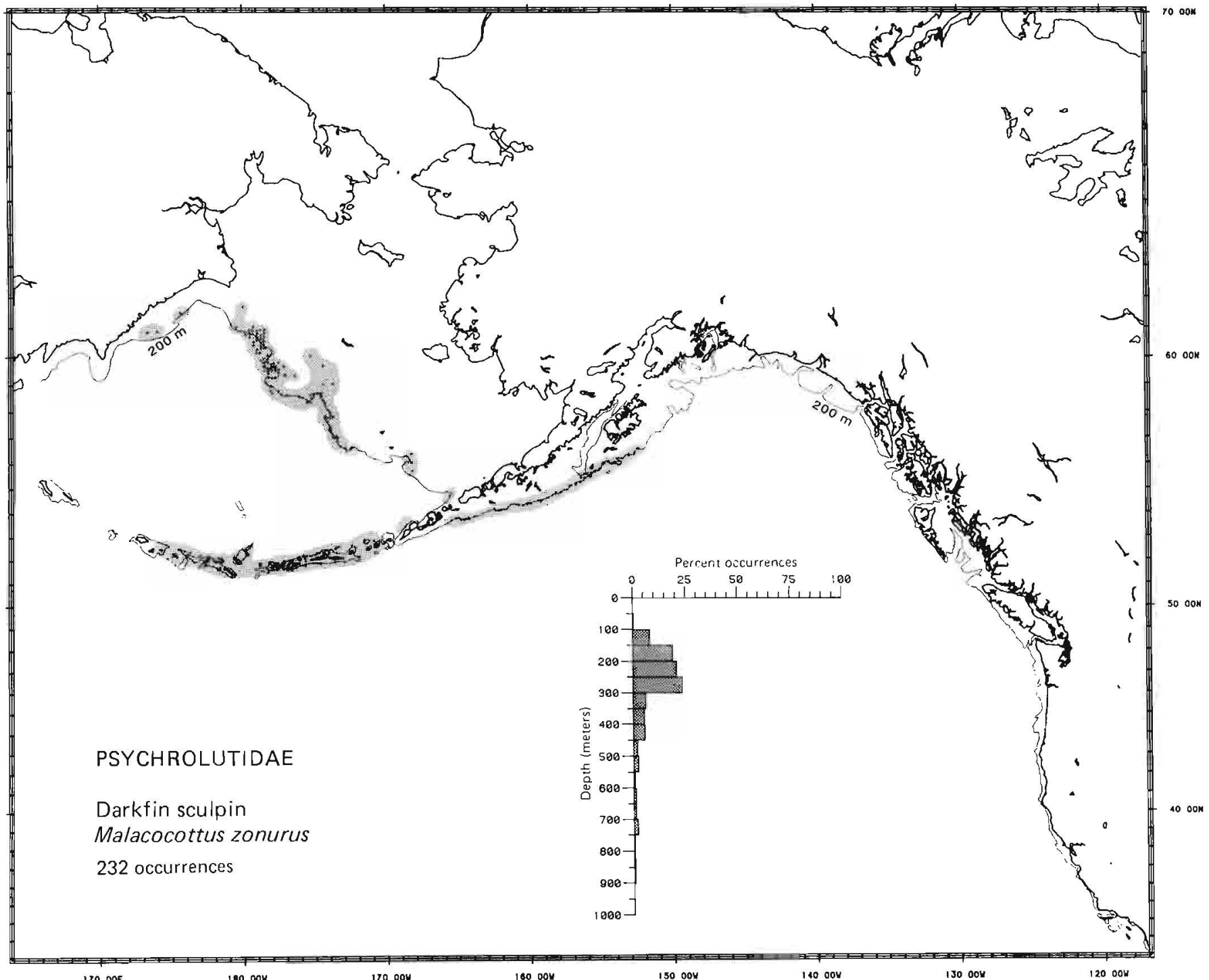


Literature Reported from the northern Sea of Japan and Sea of Okhotsk to the Arctic, south to the Gulf of Alaska, and west along the Aleutian Islands to Amchitka Island (Wilimovsky 1964; Quast and Hall 1972; Howe 1981), at depths of 22 to 223 m (Howe 1981 ).

Survey data Found from Pervenets Canyon and Nunivak Island in the eastern Bering Sea, southeast to the Alaska Peninsula and Unimak Pass, and east in the Gulf of Alaska to North Albatross Bank off Kodiak Island. Depth range 25 to 325 m, most frequently (45.7\% of occurrences) on the middle shelf between 50 and $100 \mathrm{~m}$, and $98.9 \%$ of occurrences from depths $<200 \mathrm{~m}$. Survey data provide a specific location for the species in the Gulf of Alaska and a new maximum depth record.

\section{Conclusions}

Zoogeography Arctic-northern boreal Pacific

Life zone Inner shelf-outer shelf (middle shelf)

Range From the northern Sea of Japan, Sea of Okhotsk, Amchitka Island in the Aleutian Islands, and North Albatross Bank, Kodiak Island, Alaska, north to the Arctic

Depth 22 to $325 \mathrm{~m}$

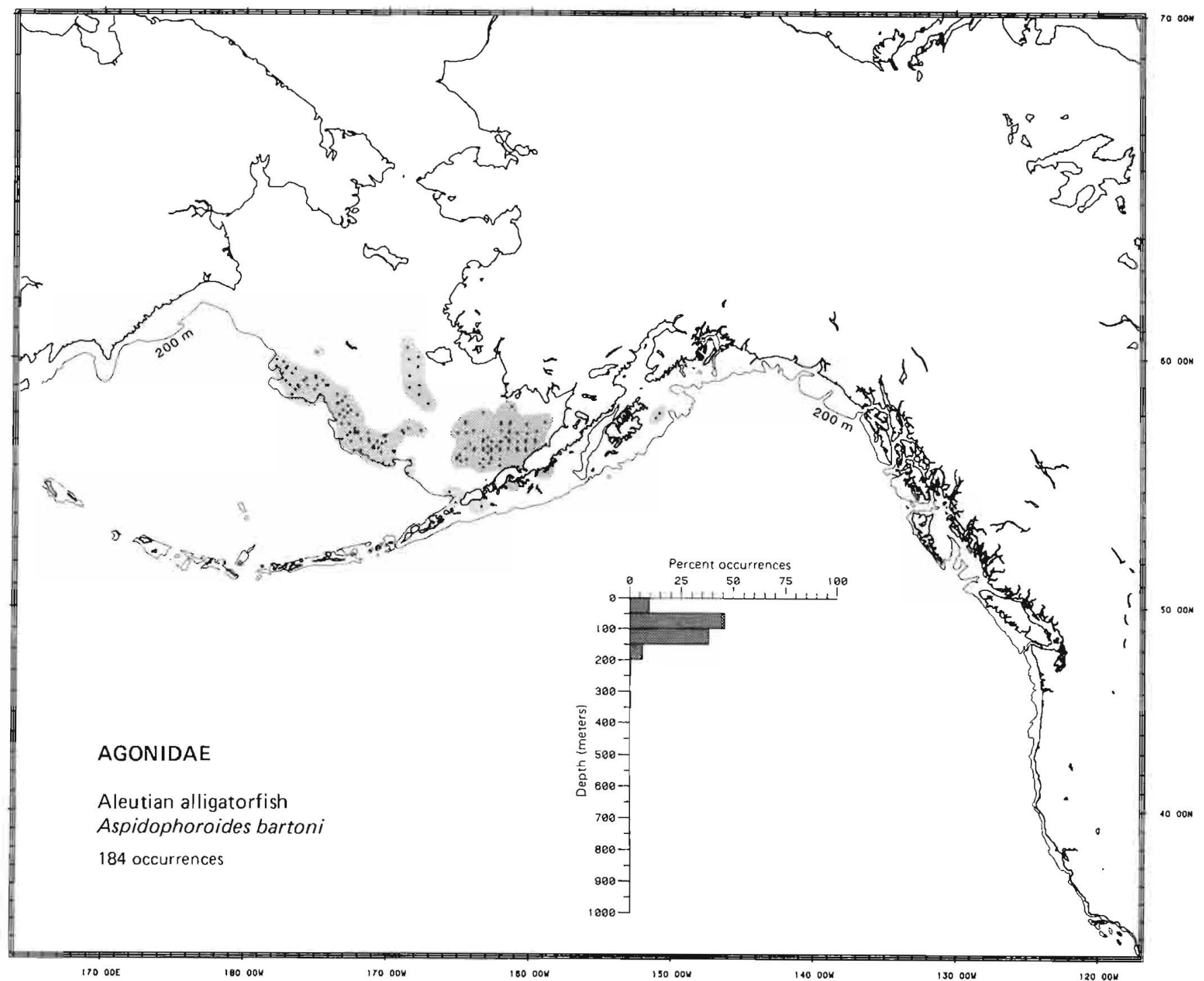


Literature Reported from Kamchatka and Bering Island to the Bering Sea and the Aleutians, and southeast to Eureka, California (Quast and Hall 1972; Hart 1973; Howe 1981; Eschmeyer and Herald 1983), at depths of 18 to $1248 \mathrm{~m}$ (Howe 1981).

Survey data Found from Navarin Canyon and north of Saint Matthew Island in the eastern Bering Sea southeast to Unimak Pass, west in the Aleutian Islands to Stalemate Bank and Bowers Bank, and east to Dixon Entrance in southeast Alaska. Depth range 25 to $975 \mathrm{~m}$, most frequently (14.0\% of occurrences) on the mesobenthal slope between 400 and $450 \mathrm{~m}$, and $94.9 \%$ of occurrences from depths of 50 to $800 \mathrm{~m}$. Survey data provide a more precise distribution in the Bering Sea and Aleutian Islands.

\section{Conclusions}

Zoogeography Eastern boreal Pacific

Life zone Middle shelf-bathybenthal (mesobenthal)

Range From Kamchatka and Bering Island north to Saint Matthew Island in the Bering Sea, west in the Aleutian Islands to

Depth 18 to $1248 \mathrm{~m}$

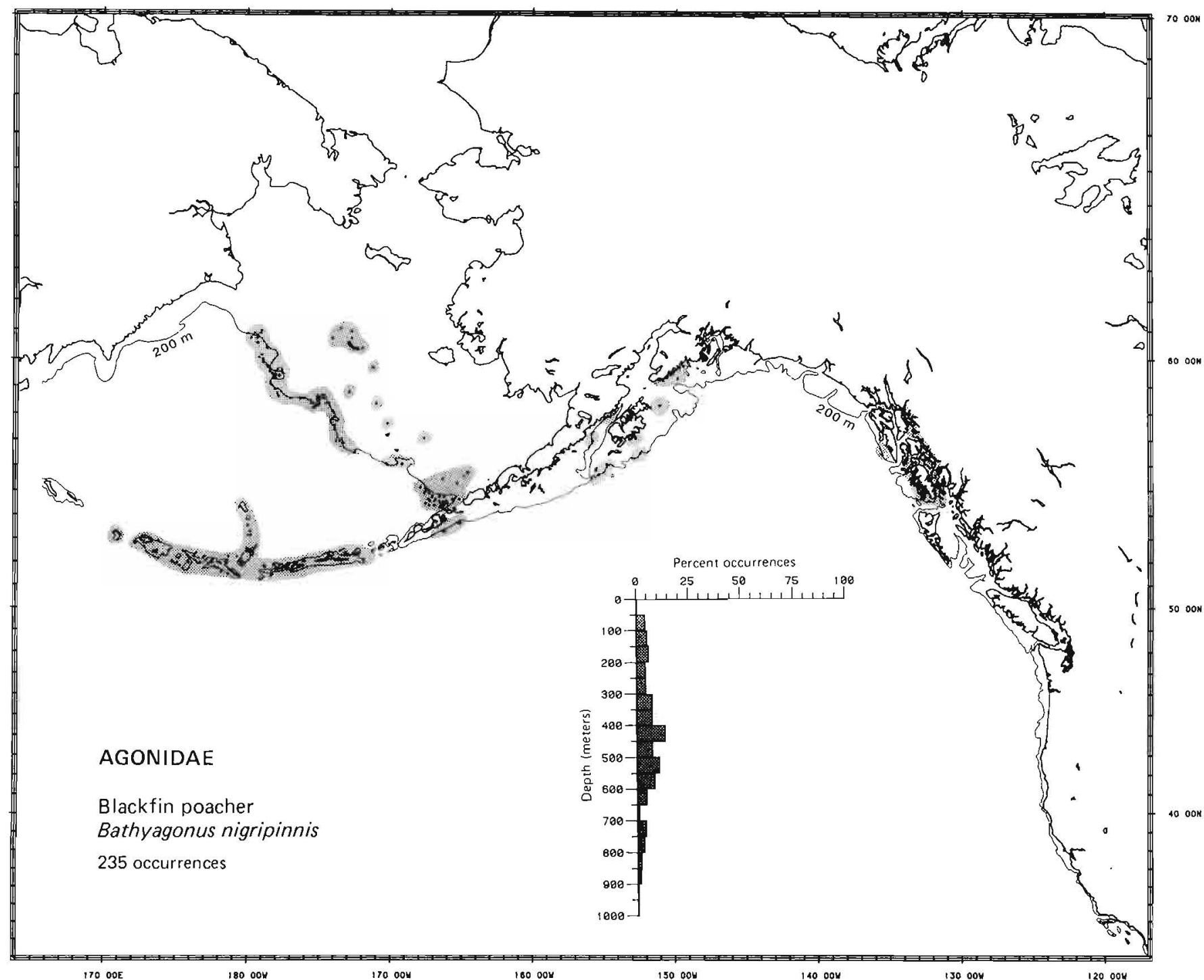


Literature Reported from the northern Sea of Japan and the Sea of Okhotsk to Olyutorski Bay and Norton Sound in the Bering Sea to Izembek Lagoon on the Alaska Peninsula (Andriyashev 1954; Wilimovsky 1964; Quast and Hall 1972), at depths of 7 to $59 \mathrm{~m}$ (Howe 1981 ).

Survey data Found from Kotzebue Sound in the Chukchi Sea south along the Alaskan coast of the eastern Bering Sea to north of Akun Island in the Aleutian Islands. Depth range 25 to $325 \mathrm{~m}$, most frequently ( $78.5 \%$ of occurrences) on the inner shelf at depths $<50 \mathrm{~m}$, and $97.3 \%$ of occurrences from depths $\leqslant 100 \mathrm{~m}$. Survey data provide a new northern limit, extend the known range to the west in the Aleutian Islands, and provide a new maximum depth record.

\section{Conclusions}

Zoogeography Arctic-Okhotsk

Life zone Inner shelf-middle shelf (inner shelf)

Range From the northern Sea of Japan and Sea of Okhotsk and Akun Island in the Aleutian Islands, north to Kotzebue Sound in the Chukchi Sea

Depth $\quad 7$ to $325 \mathrm{~m}$

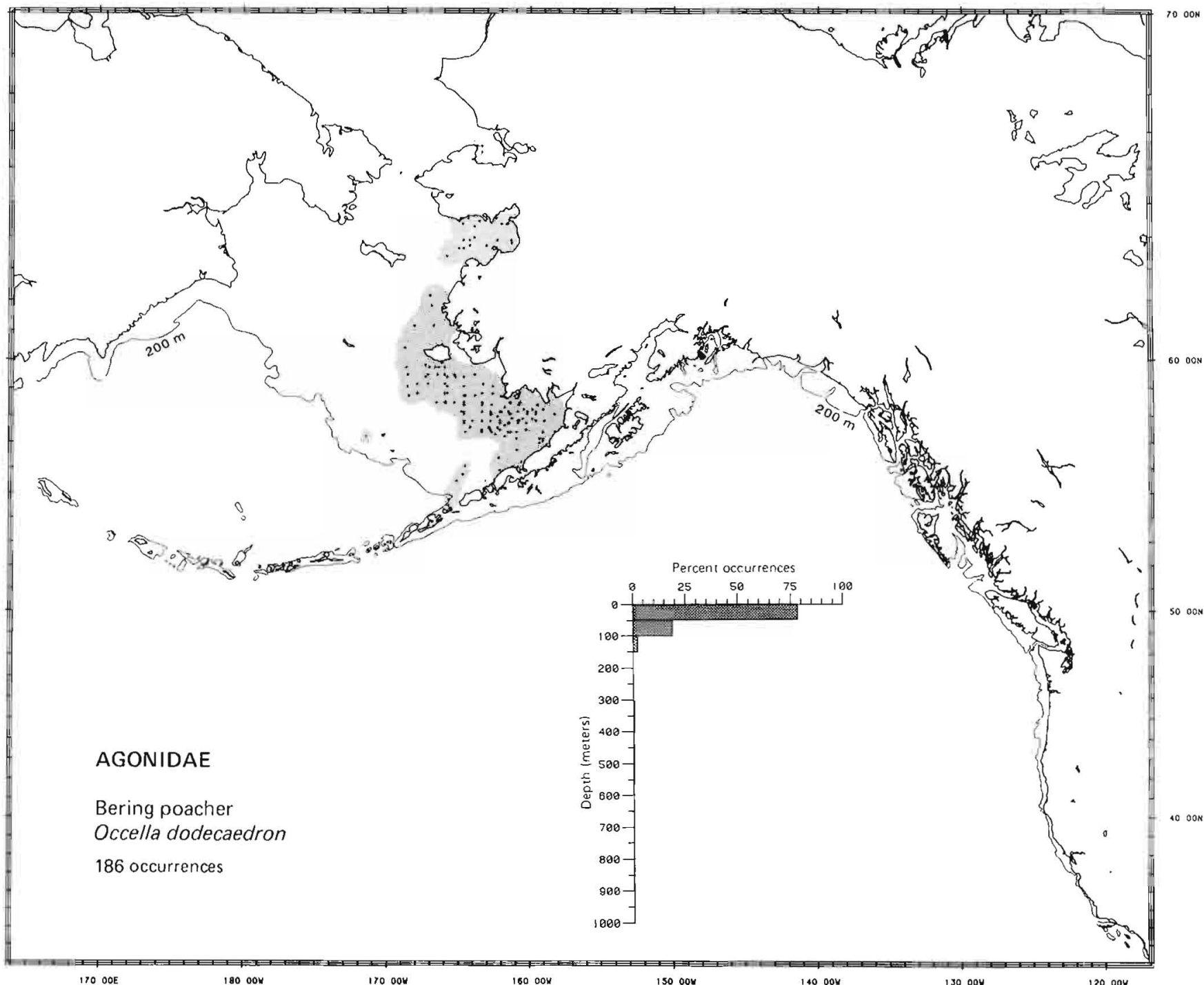


Literature Reported from Bristol Bay in the southeastern Bering Sea to Point Montara, California (Hart 1973; Eschmeyer and Herald 1983), at depths of 18 to $275 \mathrm{~m}$ (Howe 1981; Eschmeyer and Herald 1983).

Survey data Found from northern Norton Sound and the northwest eastern Bering Sea, southeast to the Alaska Peninsula and Unimak Island, and east to Kodiak Island, Alaska. Depth range 25 to $425 \mathrm{~m}$, most frequently (75.0\% of occurrences) on the inner shelf at depths $<50 \mathrm{~m}$, and $96.1 \%$ of occurrences from depths $\leqslant 150 \mathrm{~m}$. Survey data extend the known distribution in the Bering Sea to the north and provide a new maximum depth record. Because of its similarity to the Bering poacher, Occella dodecaedron, and the identification aids used in the field, some of the records of this species in the Bering Sea may actually be records of Bering poacher.

\section{Conclusions}

Zoogeography Eastern boreal Pacific

Life zone Inner shelf-outer shelf (inner shelf)

Range From Bristol Bay (possibly Norton Sound and the northwest eastern Bering Sea) to Unimak Island in the Aleutian Islands

Depth 18 to $425 \mathrm{~m}$

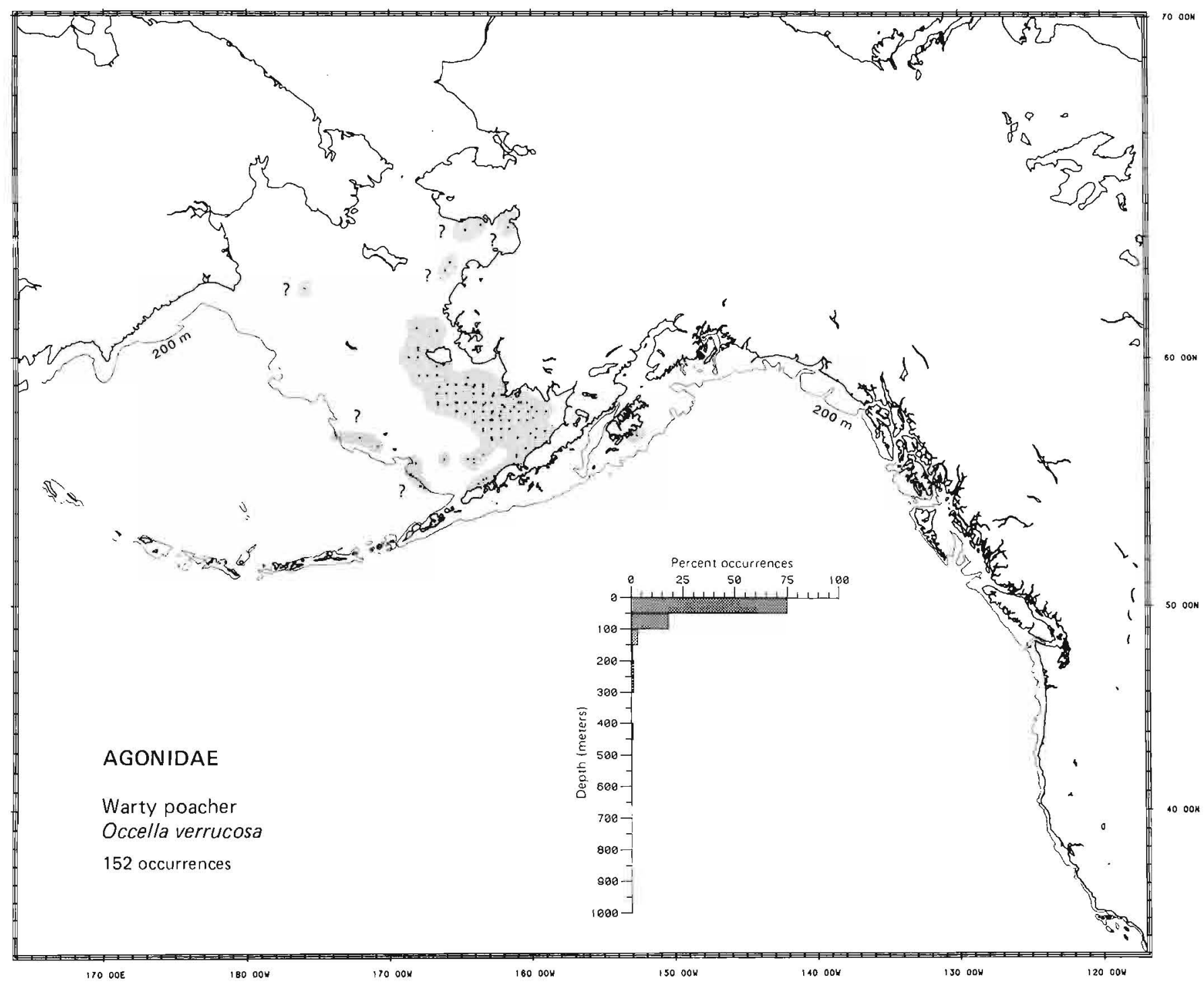


Taxonomic comment The sturgeon poacher is Agonus acipenserinus in Robins (1980), but Illina (1978), the most recent taxonomic study of this and related species, placed it in the genus Podothecus.

Literature Reported from the Arctic near Point Barrow, Alaska, south to the Anadyr Gulf in the western Bering Sea, throughout the southeastern Bering Sea, west in the Commander-Aleutian Islands to the Commander Islands, and southeast to Eureka, California (Andriyashev 1939; Wilimovsky 1964; Quast and Hall 1972; Eschmeyer and Herald 1983), at depths of 2 to $240 \mathrm{~m}$ (Fedorov 1973a; Howe 1981).

Survey data Found from north of Cape Lisburne southwest in the eastern Bering Sea to off Cape Navarin and throughout the southeastern shelf to the Alaska Peninsula and Unimak Island, west in the Aleutian Islands to Attu Island and southeast to Point Reyes, California. Depth range 25 to $475 \mathrm{~m}$, most frequently (49.9\% of occurrences) on the middle shelf between 50 and $100 \mathrm{~m}$, and $94.8 \%$ of occurrences from depths $\leqslant 150 \mathrm{~m}$. Survey data provide a new southern and maximum depth record.

\section{Conclusions}

Zoogeography Arctic-eastern boreal Pacific

Life zone Inner shelf-outer shelf (middle shelf)

Range From Point Barrow, Alaska, in the Arctic south to the Anadyr Gulf, southeast in the Bering Sea, west along the Aleutian Islands to Attu Island, and southeast to Point Reyes, California

Depth $\quad 2$ to $475 \mathrm{~m}$

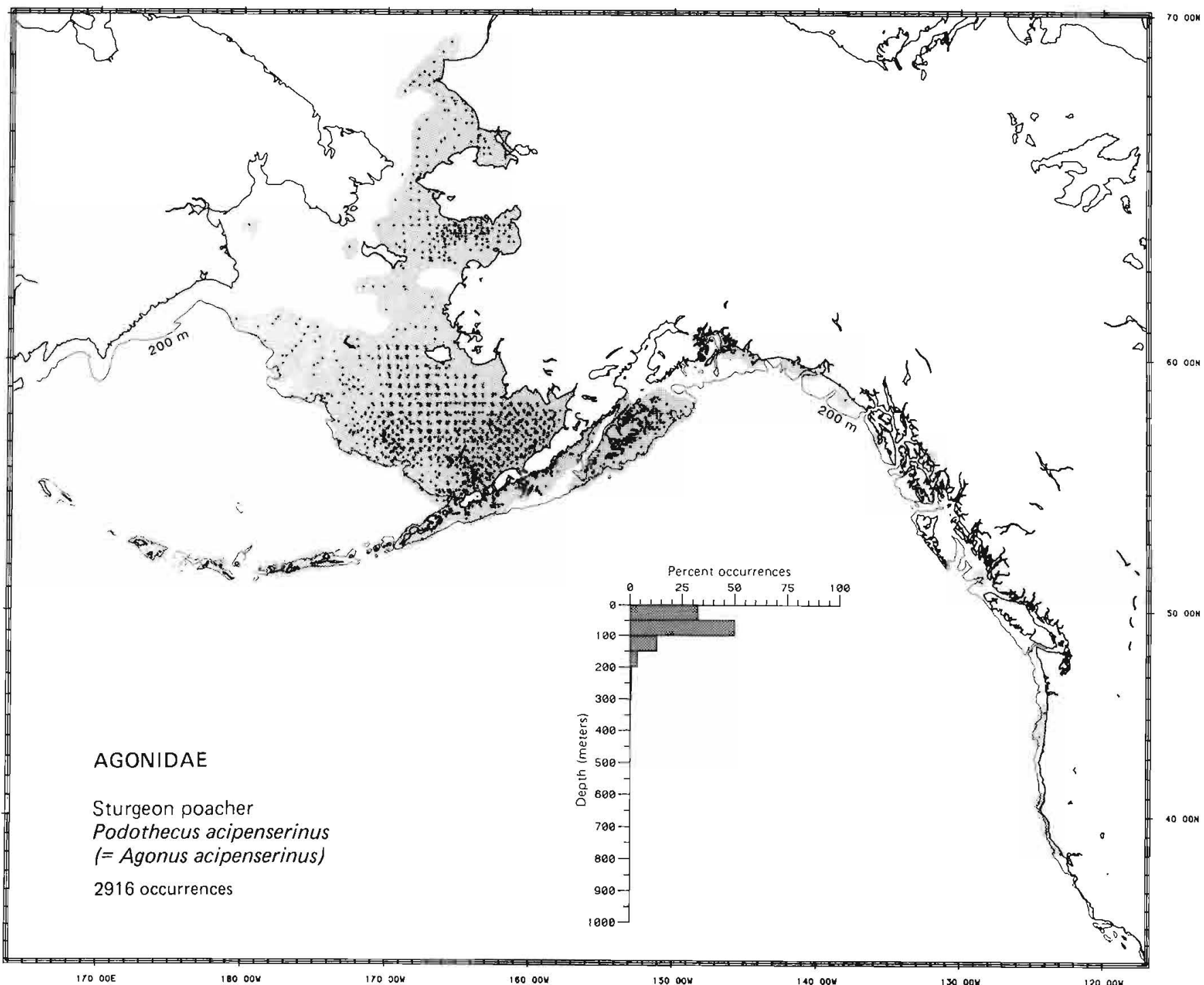


Literature Reported from Japan north to the Gulf of Anadyr and Bristol Bay, west in the Aleutian Islands to Semisopochnoi Island, and east to Alice Arm, British Columbia (Andriyashev 1954; Wilimovsky 1964; Quast and Hall 1972; Hughes and Kashino 1984), at depths of 18 to $693 \mathrm{~m}$ (Fedorov 1973a; Eschmeyer and Herald 1983).

Survey data Found from off Glubokaya Bay (on the Korak Coast of the eastern Bering Sea) to north of Norton Sound, southeast (primarily along the outer shelf and slope) to the Alaska Peninsula and Unimak Island, west in the Aleutian Islands to Stalemate Bank and Bowers Bank, and east in the Gulf of Alaska to North Albatross Bank off Kodiak Island. Depth range 25 to 975 m, most frequently (31.6\% of occurrences) on the outer shelf between 100 and $150 \mathrm{~m}$, and $95.0 \%$ of occurrences from depths of 50 to $550 \mathrm{~m}$. Survey data provide a new northern record in the eastern Bering Sea, extend the known range west in the Aleutian Islands, and provide a new maximum depth record.

\section{Conclusions}

Zoogeography Northern boreal Pacific

Life zone Middle shelf-bathybenthal (outer shelf)

Range $\quad$ From Japan to the Gulf of Anadyr and Norton Sound in the Bering Sea, west in the Aleutian Islands to Stalemate Bank, and east to Alice Arm, British Columbia

Depth $\quad 18$ to $975 \mathrm{~m}$

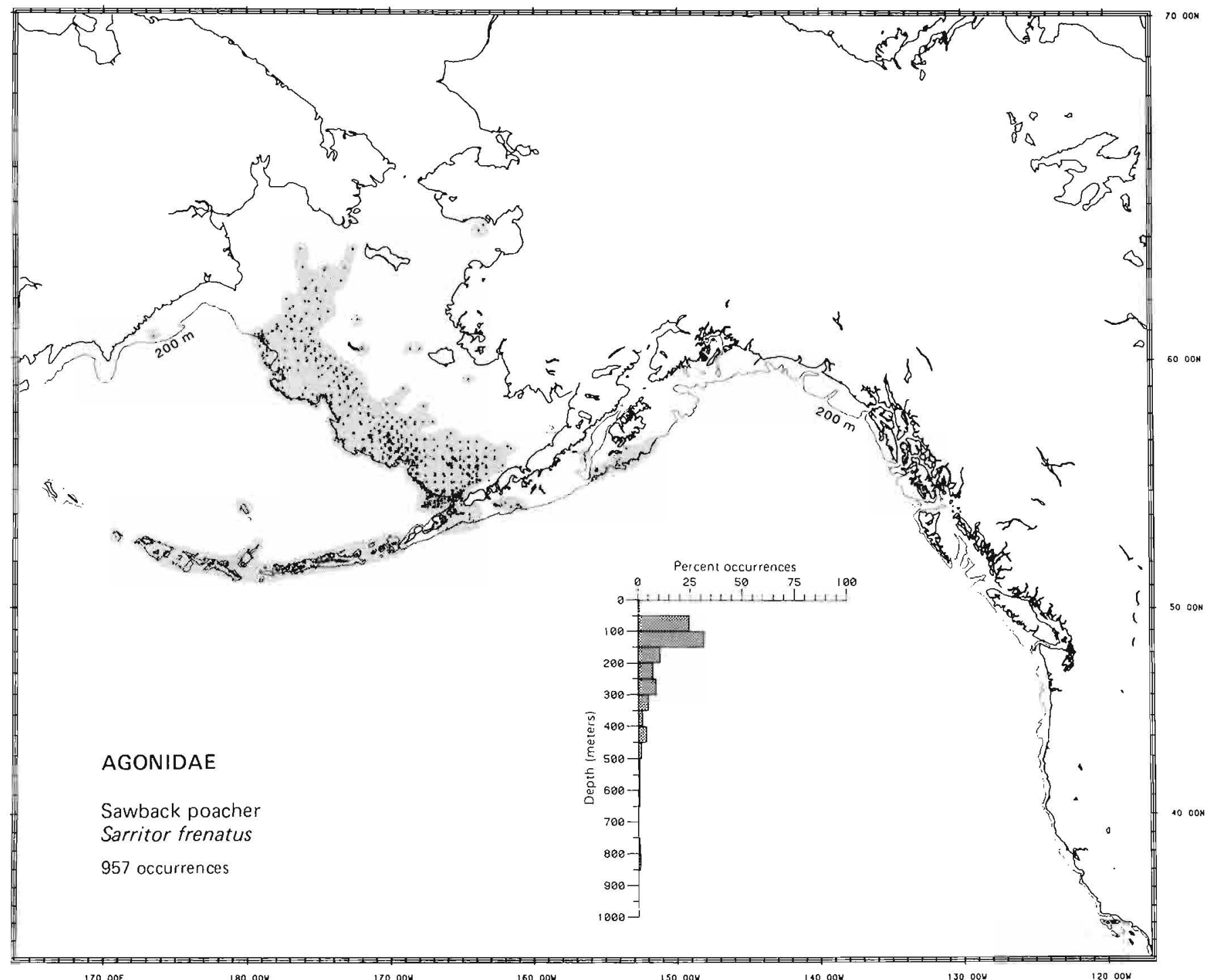


Literature Reported from Cape Navarin and Amchitka Island to Eureka, California (Quast and Hall 1972; Simenstad et al. 1977; Lea and Quirollo 1986), at depths of 60 to $800 \mathrm{~m}$ (Fedorov 1973a).

Survey data Found from off Anastasii Bay (on the Korak Coast in the western Bering Sea) north to off Cape Navarin, southeast to Bristol Bay, west in the Aleutian Islands to Attu Island and Bowers Bank, and east to Dall Island in southeast Alaska. Depth range 25 to $925 \mathrm{~m}$, most frequently ( $40.2 \%$ of occurrences) on the outer shelf between 100 and $150 \mathrm{~m}$, and $96.2 \%$ of occurrences from depths of 50 to $450 \mathrm{~m}$. Survey data extend the known range slightly to the west in the eastern Bering Sea and in the Aleutian Islands, and expand the known depth range.

\section{Conclusions}

\section{Zoogeography Aleutian}

Life zone Middle shelf-mesobenthal (outer shelf)

Range From Anastasii Bay in the western Bering Sea, north to Cape Navarin, southeast in the Bering Sea to Unimak Island, Depth 25 to $925 \mathrm{~m}$

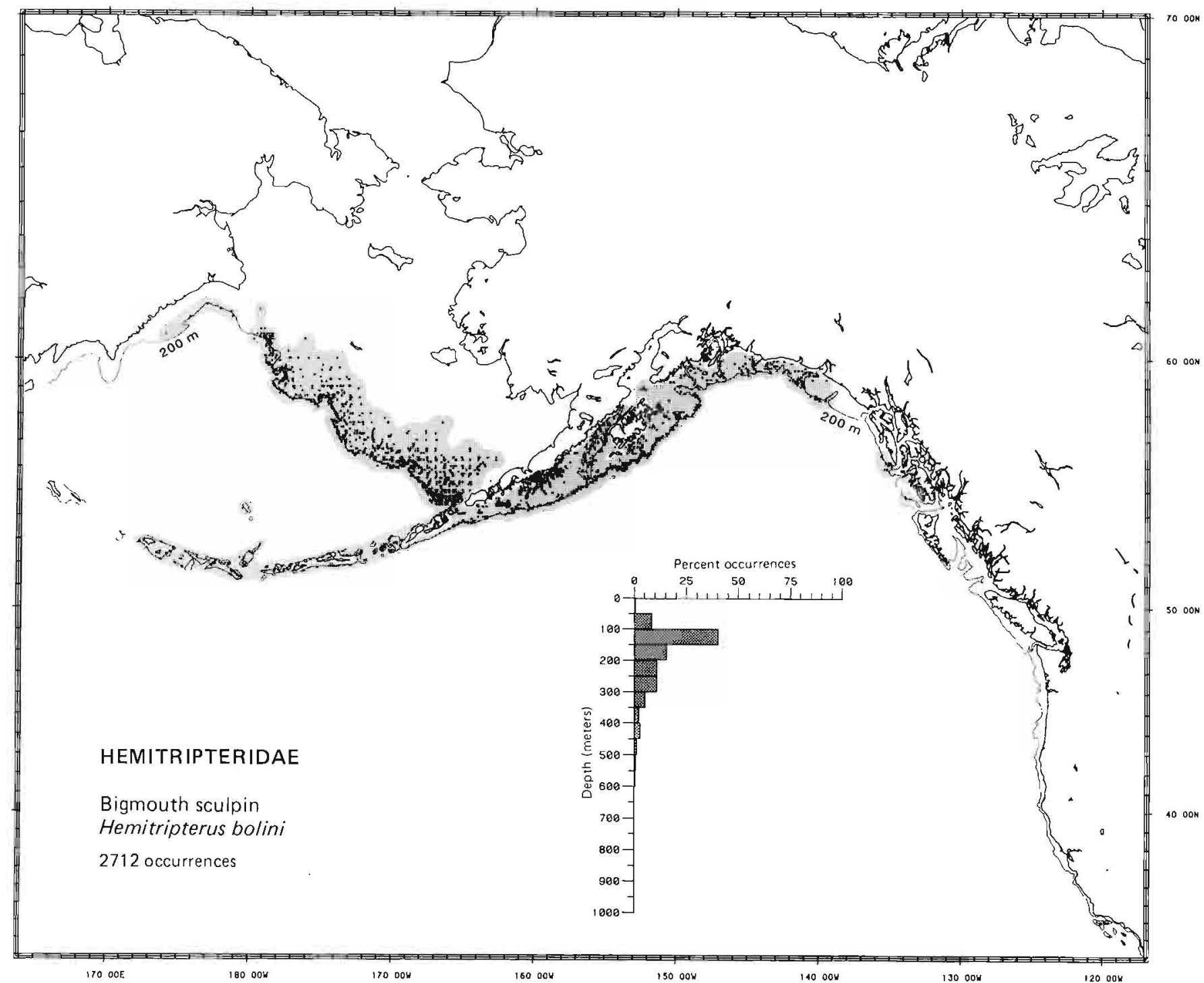


Literature Reported from the Sea of Japan and Sea of Okhotsk to the Arctic, west in the Aleutian Islands to Amchitka Island, and from there to southeast Alaska (Andriyashev 1954; Quast and Hall 1972; Simenstad et al. 1977; Howe 1981), at depths of "shallow waters" to $60 \mathrm{~m}$ (Howe 1981).

Survey data Found from west of Point Hope in the Chukchi Sea south along the Alaskan coast of the Bering Sea to off Egegik Bay on the north coast of the Alaska Peninsula and off Tanaga Island in the Aleutian Islands. Depth range 25 to $125 \mathrm{~m}$, most frequently (89.2\% of occurrences) on the inner shelf at depths $<50 \mathrm{~m}$, and $99.2 \%$ of occurrences from depths $\leqslant 100 \mathrm{~m}$. Survey data provide a more specific northern limit in the Arctic and expand the known depth range.

\section{Conclusions}

Zoogeography Arctic-northern boreal Pacific

Life zone Inner shelf-middle shelf (inner shelf)

Range From the Sea of Japan to Point Hope in the Chukchi Sea southeast to southeastern Alaska, and west to Amchitka Island in the Aleutian Islands

Depth 25 to $125 \mathrm{~m}$

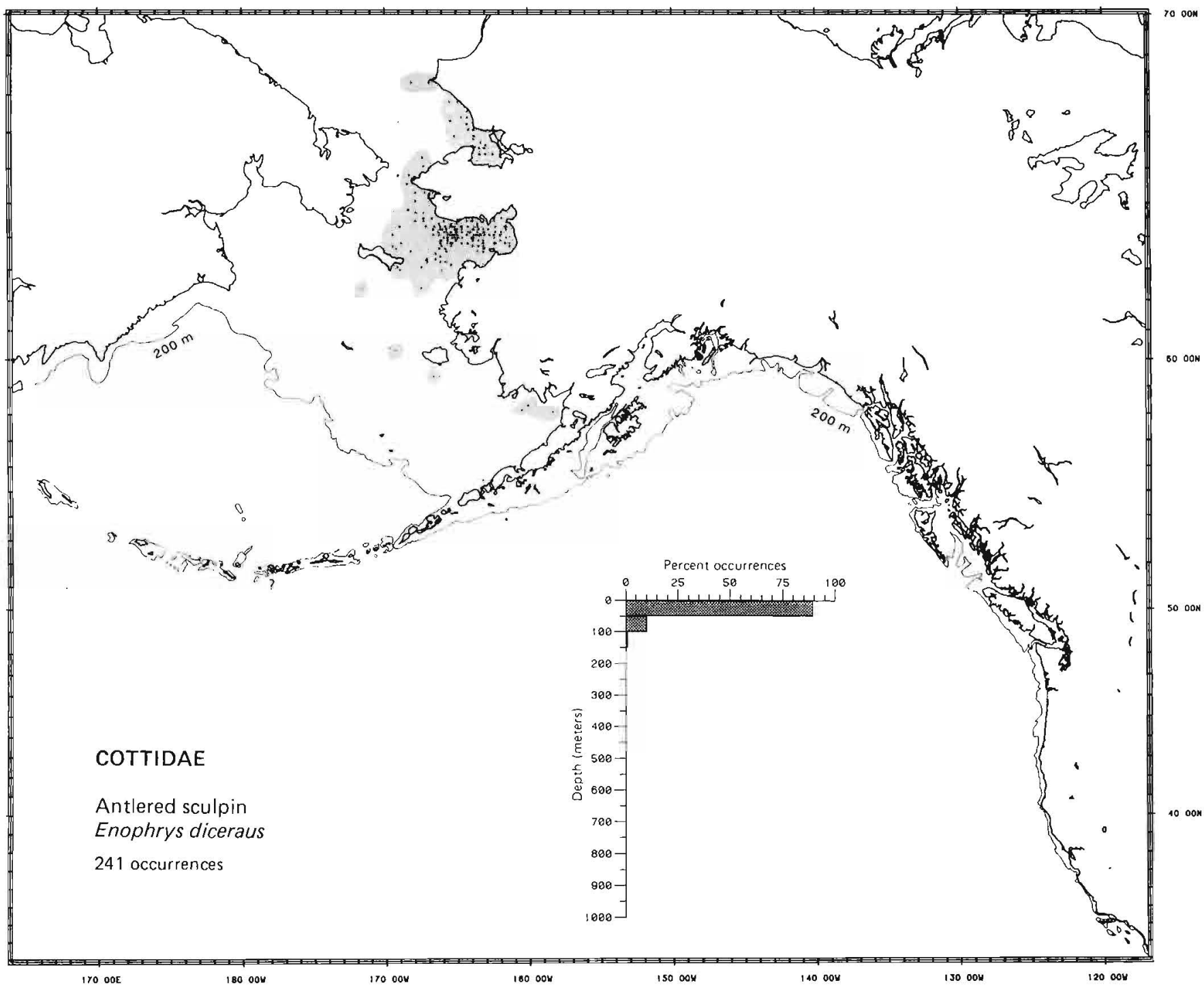


Literature Reported from Hokkaido, Japan, to the Bering Sea (but not in the Sea of Okhotsk) and from Amchitka Island in the Aleutian Islands east to Wales Island, British Columbia (Shmidt 1950; Quast and Hall 1972; Eschmeyer and Herald 1983), at depths of 0 to $167 \mathrm{~m}$ (Howe 1981; Eschmeyer and Herald 1983).

Survey data Found in Pervenets Canyon on the northwest slope of the eastern Bering Sea, south of Saint Lawrence Island, southeast along the inner and middle shelf of the Bering Sea, and from Agattu Island in the Aleutian Islands east to Stevenson Entrance east of Afognak Island in the Gulf of Alaska. Depth range 25 to $625 \mathrm{~m}$, most frequently $(54.3 \%$ of occurrences) on the middle shelf between 50 and $100 \mathrm{~m}$, and $93.5 \%$ of occurrences from depths $\leqslant 150 \mathrm{~m}$. Survey data provide a more precise northern limit in the Bering Sea, extend the known range to the west in the Aleutian Islands, and extend the maximum known depth of occurrence. However, deep records for this species are anomalous and must be regarded as questionable.

\section{Conclusions}

\section{Zoogeography Kurile-Aleutian}

Life zone Inner shelf-outer shelf (middle shelf)

Range From Hokkaido, Japan, to south of Saint Lawrence Island in the Bering Sea (but not in the Sea of Okhotsk), west to $\begin{array}{ll} & \text { Agattu Island in the Aleutian Is } \\ \text { Depth } & 0 \text { to } 167 \mathrm{~m} \text { (possibly to } 625 \mathrm{~m} \text { ) }\end{array}$

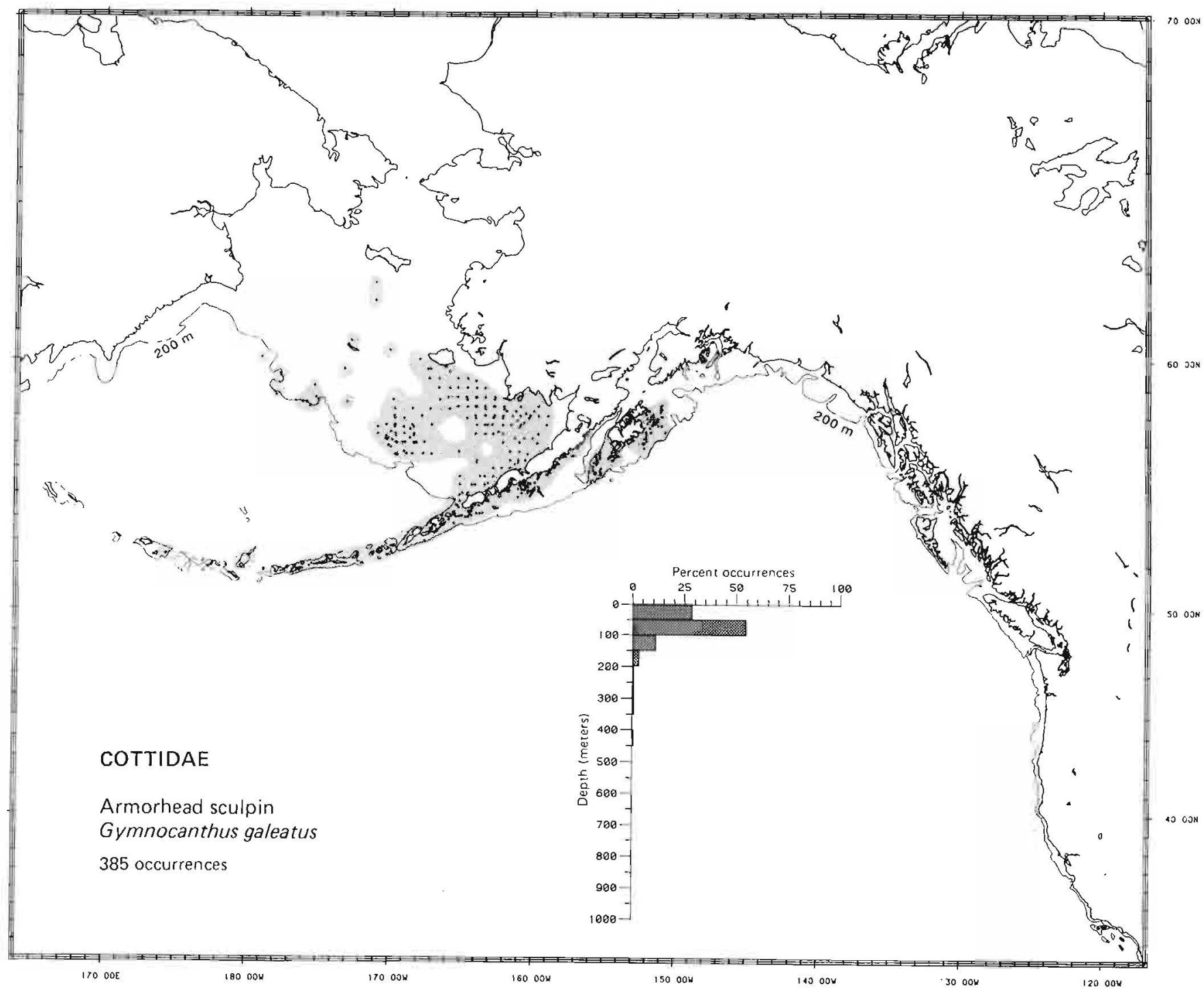


Literature Reported from the Sea of Japan and the Sea of Okhotsk to the Chukchi Peninsula in the Bering Sea, along the Aleutian Islands to Kiska Island, and east to southeastern Alaska (Andriyashev 1954; Wilimovsky 1964; Eschmeyer and Herald 1983), at depths of 0 to $100 \mathrm{~m}$ (Howe 1981; Eschmeyer and Herald 1983).

Survey data Found west of Saint Lawrence Island, from Norton Sound south in the eastern Bering Sea to Unalaska Island in the Aleutian Islands, and from there east along the Alaska Peninsula to Puale Bay. Depth range 25 to $325 \mathrm{~m}$, most frequently (61.5\% of occurrences) on the inner shelf at depths $<50 \mathrm{~m}$, and $94.6 \%$ of occurrences from depths $<100 \mathrm{~m}$. Survey data provide a new maximum depth record but do not significantly alter the known geographic range.

\section{Conclusions}

Zoogeography Northern boreal Pacific

Life zone Inner shelf-middle shelf (inner shelf) species

Range From the Sea of Japan and the Sea of Okhotsk to the Chukchi Peninsula and Norton Sound in the Bering Sea, west in the Aleutian Islands to Kiska Island, and east to southeastern Alaska

Depth 0 to $325 \mathrm{~m}$

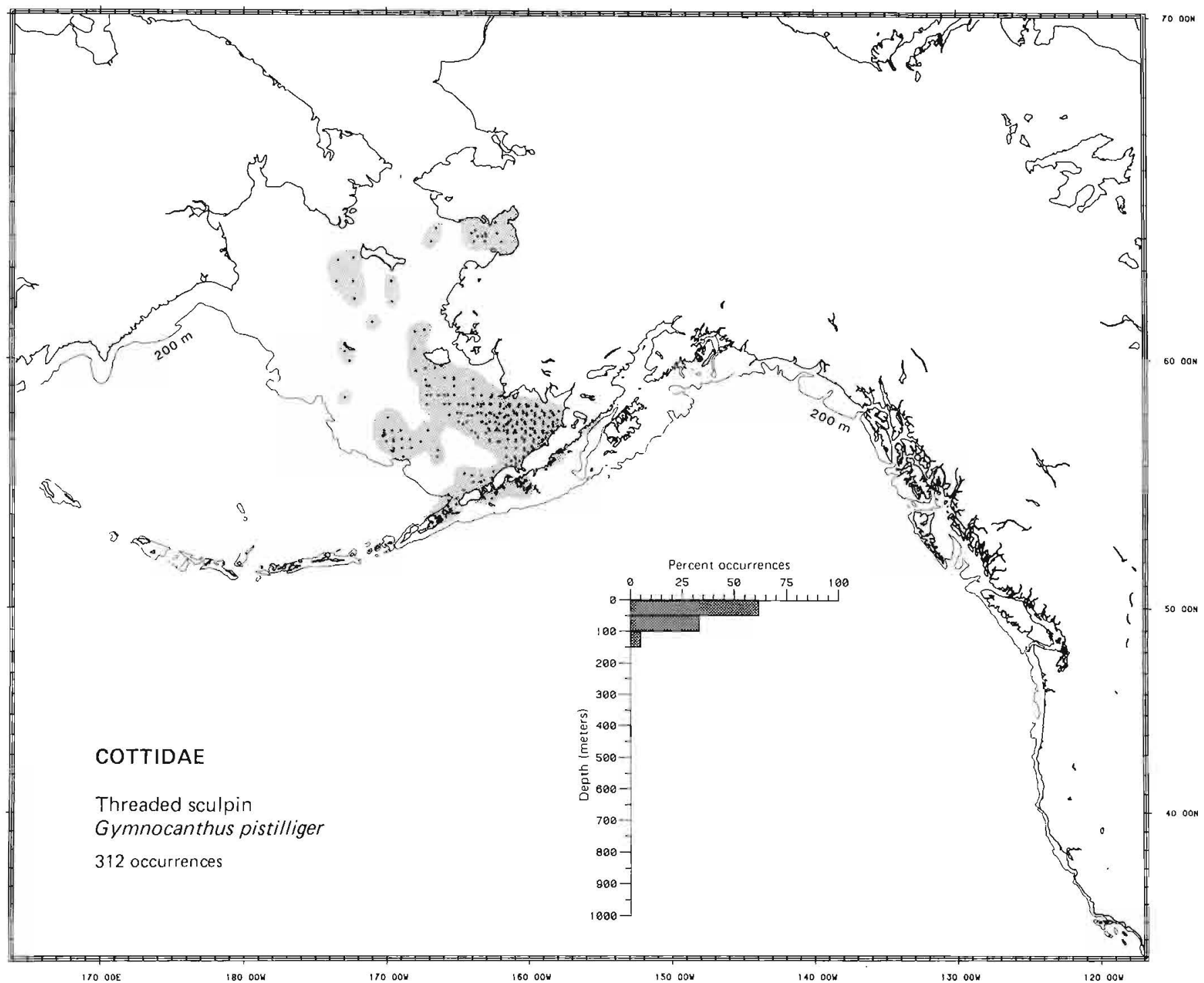


Literature Reported from Natalii Bay (on the Korak Coast of the western Bering Sea) north to the Arctic where it is circumpolar, its range extending into the Atlantic as far as Eastport, Maine, western Greenland, and Norway, from depths of 0 to $240 \mathrm{~m}$ (Andriyashev 1954).

Survey data Found from northeast of Cape Lisburne in the Chukchi Sea to north of Unimak Island in the Bering Sea and along the Aleutian Islands to Agattu Island. Depth range 25 to $825 \mathrm{~m}$, most frequently (54.4\% of occurrences) on the inner shelf at depths $<50 \mathrm{~m}$, and $95.9 \%$ of occurrences from depths $<150 \mathrm{~m}$. Survey data extend the known southern limit in the North Pacific to Agattu Island in the Aleutian Islands and provide a new maximum depth record. However, depth records greater than $200 \mathrm{~m}$ appear to be anomalous and must be regarded as questionable.

\section{Conclusions}

Zoogeography Arctic-circumboreal Atlantic

Life zone Inner shelf-outer shelf (inner shelf)

Range From Natalii Bay in the western Bering Sea and Agattu Island in the Aleutian Islands north throughout the Arctic and south in the Atlantic to Eastport, Maine, western Greenland, and Norway

Depth $\quad 0$ to $240 \mathrm{~m}$ (possibly to $825 \mathrm{~m}$ )

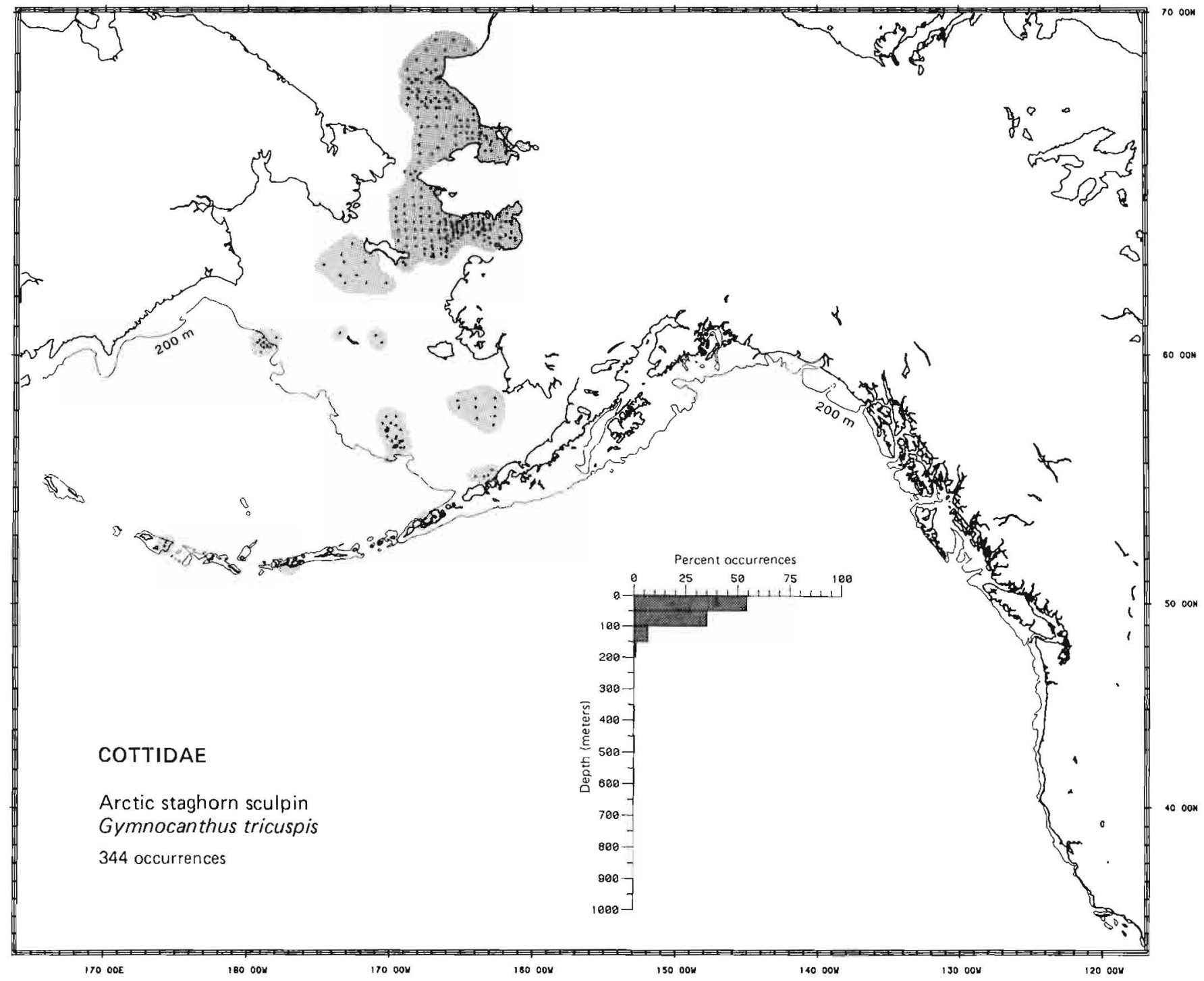


Literature Reported from Cape Piratkova to the Gulf of Ozernoy in southeastern Kamchatka, along the Commander and Aleutian Islands, north in the southeastern Bering Sea to Saint Paul Island, and southeast to Mussel Point, California (Hart 1973; Peden 1978), at depths from the intertidal zone to $80 \mathrm{~m}$ (Peden 1978; Howe 1981).

Survey data Found from off Port Clarence in the northern Bering Sea and Cape Navarin in the northwestern shelf of the eastern Bering Sea southeast to Bristol Bay and from there west along the Aleutian Islands to Kiska Island and east in the Gulf of Alaska to off Yakutat Bay. Depth range 25 to $275 \mathrm{~m}$, most frequently (44.3\% of occurrences) on the middle shelf between 50 and $100 \mathrm{~m}$, and $95.6 \%$ of occurrences from depths of 50 to $250 \mathrm{~m}$. Survey data extend the known range north and northwest in the Bering Sea and provide a new maximum depth record. However, in the northern and northwestern portion of the eastern Bering Sea, records of this species may actually be records of female butterfly sculpin, Hemilepidotus papilio (D. W. Kessler, Kodiak Lab., Northwest and Alaska Fish. Cent., Natl. Mar. Fish. Serv., NOAA, Kodiak, AK 99615, pers. commun. August 1983). Hence the northwest extension of the range of this species in the Bering Sea must be regarded as questionable.

\section{Conclusions}

Zoogeography Eastern boreal Pacific

Life zone Middle shelf-mesobenthal (middle shelf)

Range From Cape Piratkova to the Gulf of Ozernoy in southeastern Kamchatka, along the Commander and Aleutian Islands, north in the Bering Sea to Saint Paul Island, and southeast to Mussel Point, California

Depth Intertidal zone to $275 \mathrm{~m}$

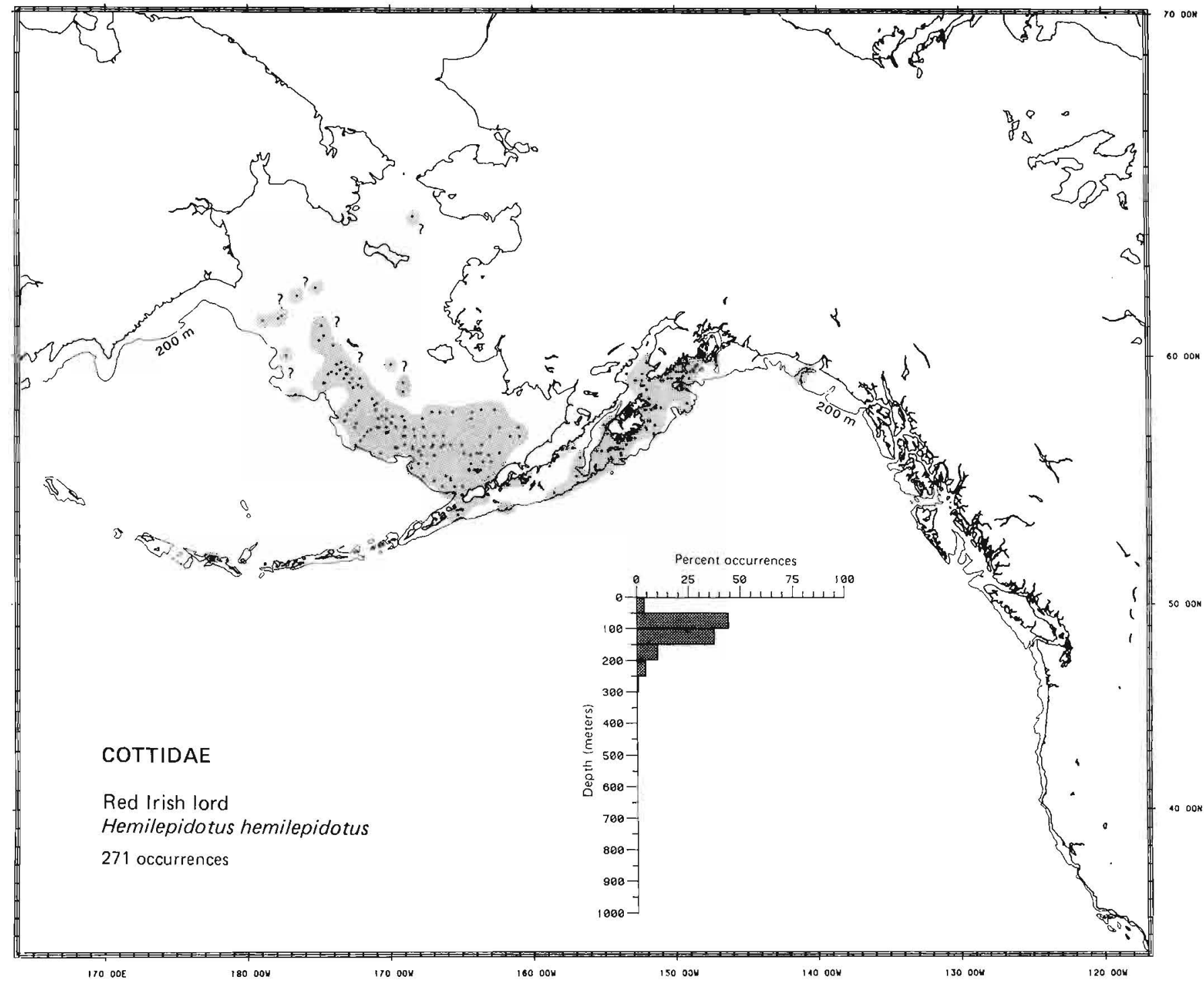


Literature Reported from the northern Kurile Islands and southwestern Kamchatka north to the Anadyr Gulf, southeast in the eastern Bering Sea to the Alaska Peninsula, west throughout the Aleutian and Commander Islands, and east to Sitka, Alaska (Peden 1978), at depths "subtidal" to $220 \mathrm{~m}$ (Peden 1978; Howe 1981).

Survey data Found from Cape Olyutorski in the western Bering Sea north to the southern Chukchi Sea, southeast to Bristol Bay, and from there west to Stalemate Bank in the Aleutian Islands and east to Icy Strait in southeast Alaska. Depth range 25 to $525 \mathrm{~m}$, most frequently ( $40.6 \%$ of occurrences) on the outer shelf between 100 and $150 \mathrm{~m}$, and $97.6 \%$ of occurrences from depths $\leqslant 250 \mathrm{~m}$. Survey data provide a new known northern limit and more precisely define and expand the known depth distribution.

\section{Conclusions}

Zoogeography Kurile-Aleutian

Life zone

Inner shelf-mesobenthal (outer shelf)

Range

From the northern Kurile Islands and southwest Kamchatka north to the Anadyr Gulf and east to Sitka, Alaska (including the Commander and Aleutian Islands)

Depth 25 to $525 \mathrm{~m}$

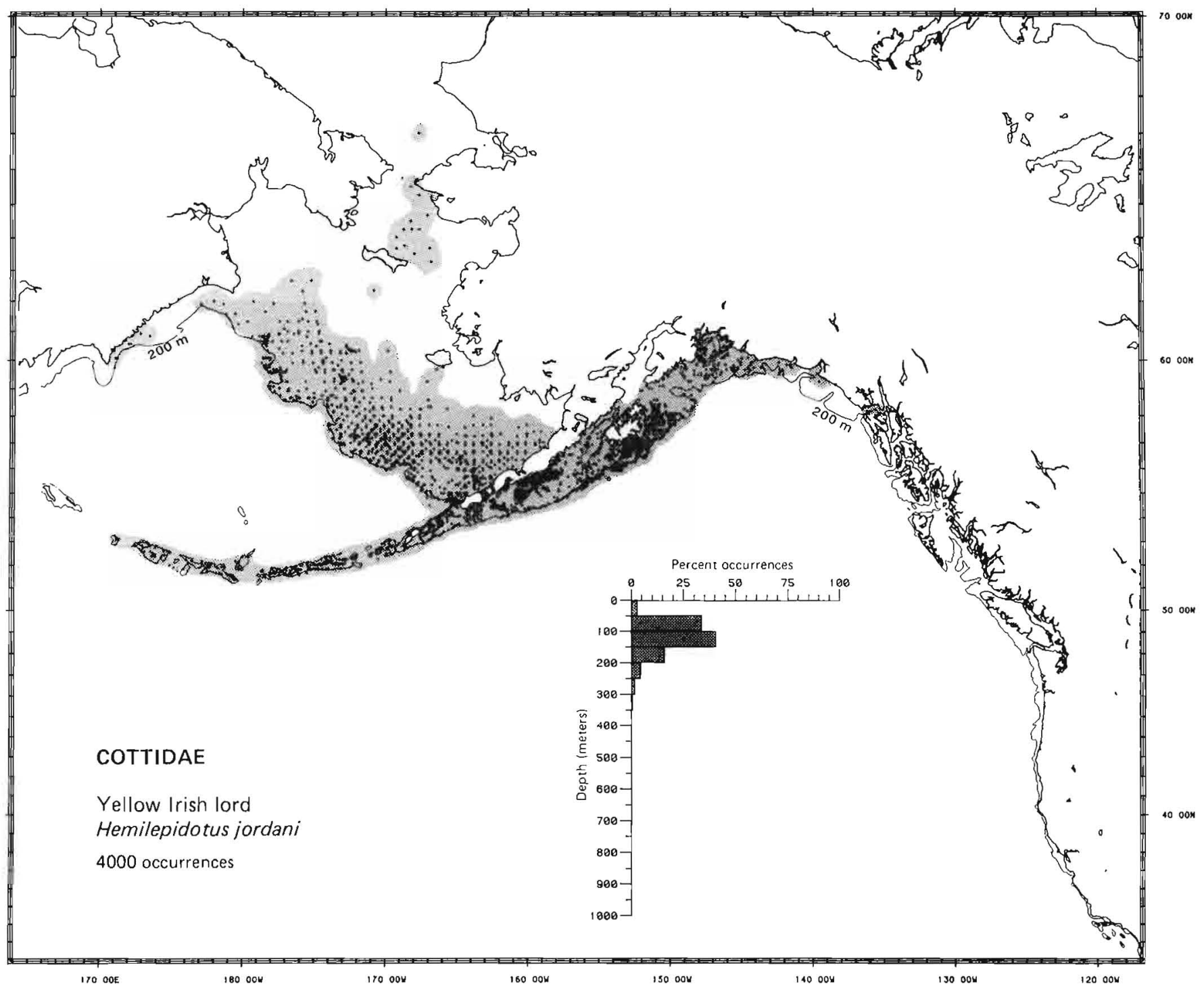


Taxonomic comment The butterfly sculpin is Melletes papilio in Robins (1980) but Peden (1978), the most recent revision of hemilepidotine cottids, placed this species in the genus Hemilepidotus.

Literature Reported from Hokkaido, Japan, and the Sea of Okhotsk to the Chukchi Sea and southeast in the Bering Sea to east of the Pribilof Islands (Andriyashev 1954; Peden 1978; Howe 1981), at depths of 20 to $240 \mathrm{~m}$ (Fedorov 1973a).

Survey data Found from northeast of Cape Olyutorski in the western Bering Sea north to Cape Chukotskiy, Siberia, and Nome, Alaska, southeast to Bristol Bay and west in the Aleutian Islands to Buldir Island. Depth range 25 to $275 \mathrm{~m}$, most frequently (74.2\% of occurrences) on the middle shelf between 50 and $100 \mathrm{~m}$, and $99.1 \%$ of occurrences from depths $\leqslant 150 \mathrm{~m}$. Survey data extend the known range into the Aleutian Islands and provide a new maximum depth record.

\section{Conclusions}

Zoogeography Arctic-Okhotsk

Life zone Inner shelf-outer shelf (middle shelf)

Range From Hokkaido, Japan, and the Sea of Okhotsk, north to the Chukchi Sea, southeast in the Bering Sea, and southwest to Buldir Island in the Aleutian Islands

Depth 20 to $275 \mathrm{~m}$

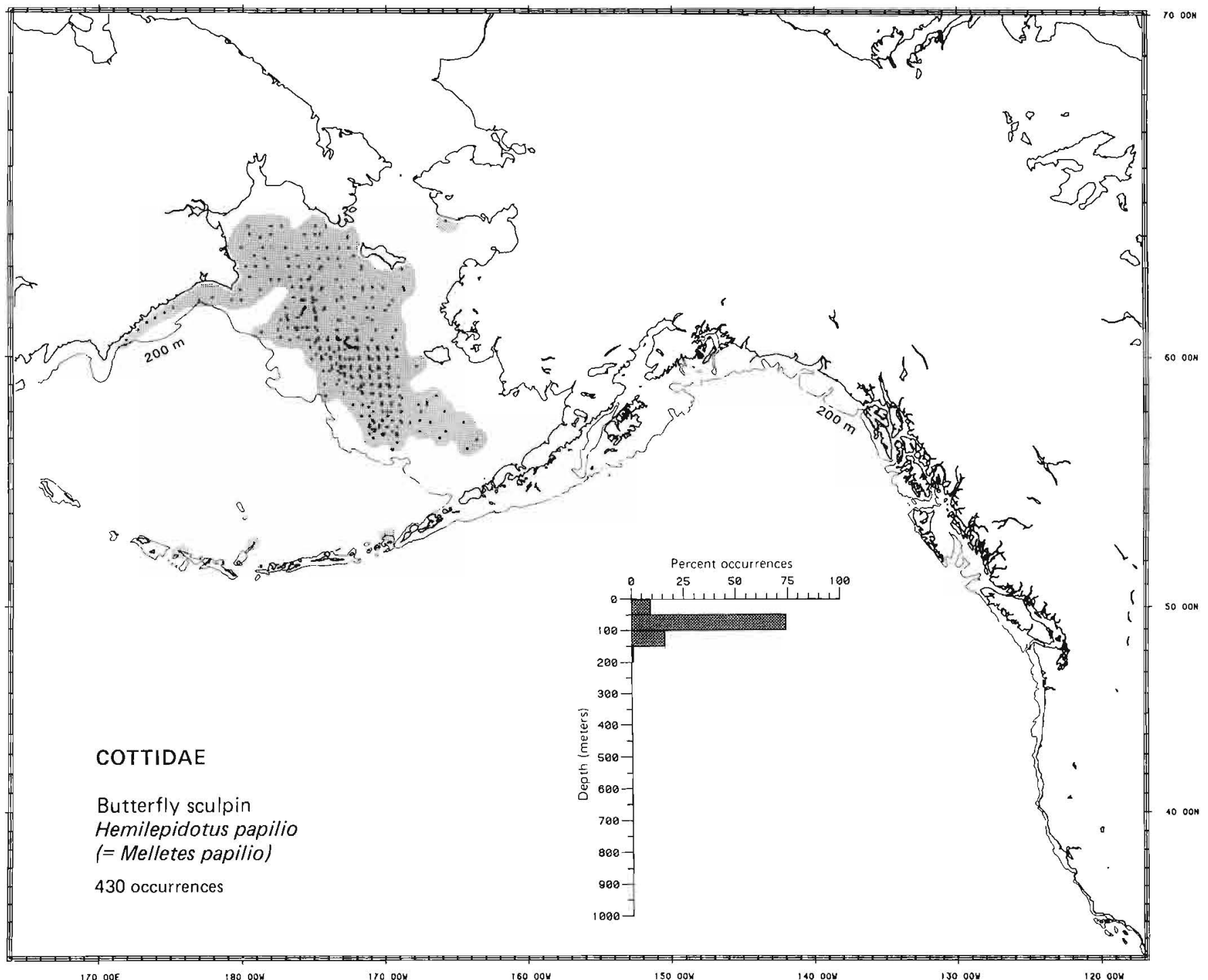


Literature Reported from northern British Columbia to Point Loma and Cortez Bank in southern California (Hart 1973; Eschmeyer and Herald 1983), at depths of 18 to $800 \mathrm{~m}$ (Howe 1981; Eschmeyer and Herald 1983).

Survey data Found from east of Chirikof Island (south of Kodiak Island) to the Santa Barbara Channel, California. Depth range 25 to $225 \mathrm{~m}$, most frequently (47.6\% of occurrences) on the outer shelf between 150 and $200 \mathrm{~m}$, and $96.4 \%$ of occurrences from depths of 50 to $300 \mathrm{~m}$. Survey data extend the known range to the northwest Gulf of Alaska.

\section{Conclusions}

Zoogeography Eastern boreal Pacific

Life zone Middle shelf-mesobenthal (outer shelf)

Range From Chirikof Island in the western Gulf of Alaska to Point Loma and Cortez Bank in southern California Depth $\quad 18$ to $800 \mathrm{~m}$

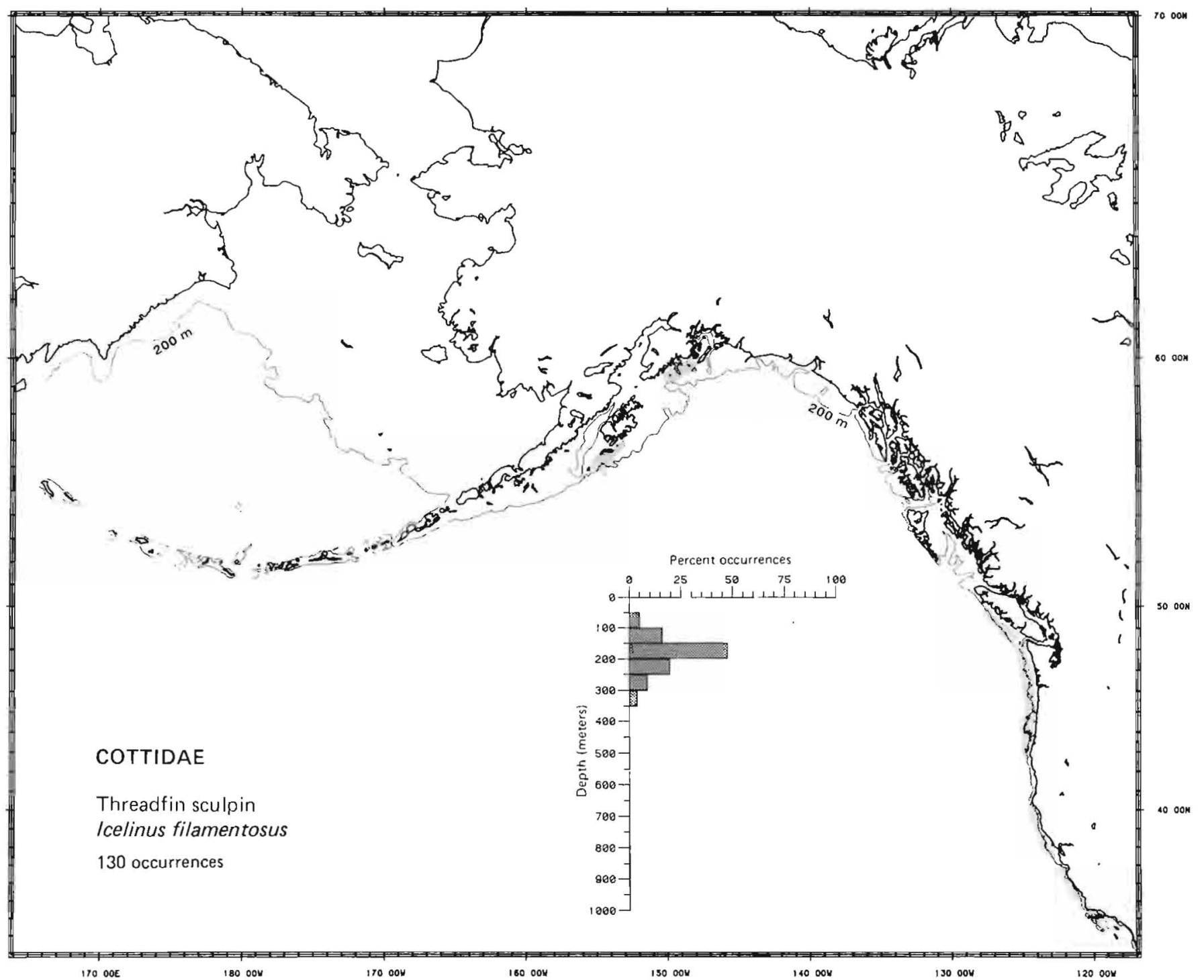


Literature Reported from Hokkaido, Japan, to the eastern Bering Sea, west to Unalaska Island in the Aleutian Islands, and east to the Gulf of Alaska (Quast and Hall 1972; Howe 1981; Yabe et al. 1983), at depths of 20 to $800 \mathrm{~m}$ (Nelson, D. W. 1984).

Survey data Found from Navarin Canyon on the northwest slope of the eastern Bering Sea, southeast to Akutan Island in the Aleutian Islands and west to Agattu Island. Depth range 175 to $925 \mathrm{~m}$, most frequently (16.3\% of occurrences) on the bathybenthal slope between 500 and $550 \mathrm{~m}$, and $96.1 \%$ of occurrences from depths of 250 to $900 \mathrm{~m}$. Survey data provide a more precise northern limit in the Bering Sea, extend the known range westward in the Aleutian Islands, and provide a new maximum depth record.

\section{Conclusions}

Zoogeography Northern boreal Pacific

Life zone Mesobenthal-bathybenthal (bathybenthal)

Range From Hokkaido, Japan, to Navarin Canyon in the Bering Sea, southeast along the slope of the eastern Bering Sea to the Aleutian Islands, west in the Aleutian Islands to Agattu Island, and east to the Gulf of Alaska

Depth 26 to $925 \mathrm{~m}$

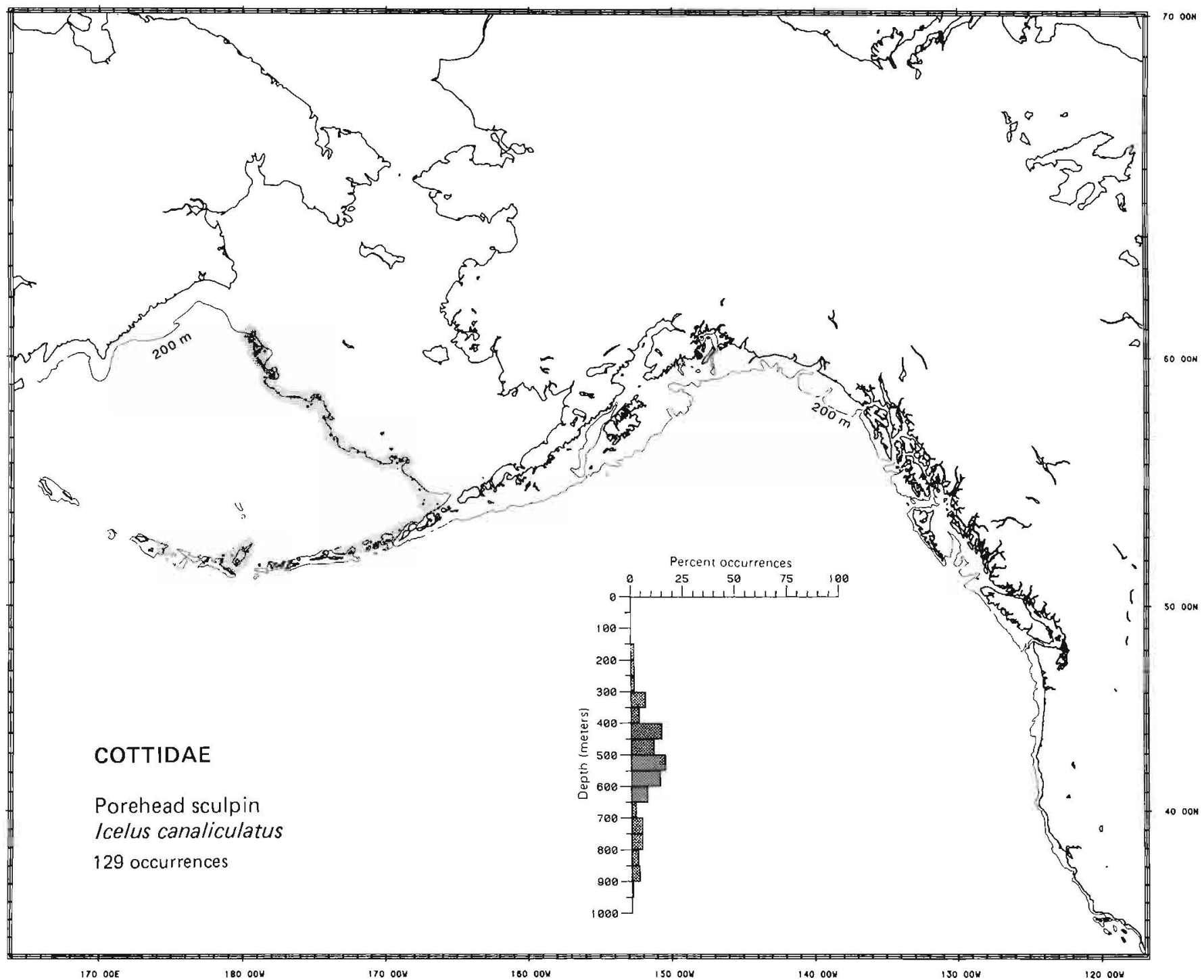


Literature Reported from the eastern Sea of Okhotsk to Cape Navarin in the Bering Sea, along the Commander and Aleutian Islands, and southeast to Vancouver Island, British Columbia (Okada and Kobayashi 1968; Nelson, D. W. 1984), from 31 to $770 \mathrm{~m}$ depths (Fedorov 1973a; Eschmeyer and Herald 1983).

Survey data Found from off Glubokaya Bay (on the Korak Coast of the western Bering Sea) north to Norton Sound, southeast to off Hagemeister Strait in Bristol Bay, west along the Aleutian Islands to Agattu Island, and east to off Lituya Bay in southeastern Alaska. Depth range 25 to $675 \mathrm{~m}$, most frequently (56.1\% of occurrences) on the outer shelf between 100 and $150 \mathrm{~m}$, and $95.7 \%$ of occurrences from depths $<300 \mathrm{~m}$. Survey data provide a more precise distribution in the Bering Sea, extend the known range westward in the Aleutian Islands, and provide a shallower depth record. The presence of this species in Norton Sound appears to be anomalous; records from that region may be of other Icelus species.

\section{Conclusions}

Zoogeography Northern boreal Pacific

Life zone Inner shelf-mesobenthal (outer shelf)

Range From the eastern Sea of Okhotsk to Cape Navarin (possibly Norton Sound) in the Bering Sea, west in the Aleutian

$\begin{array}{ll}\text { Depth } & \text { Islands to } \mathrm{Ag} \\ & 25 \text { to } 770 \mathrm{~m}\end{array}$

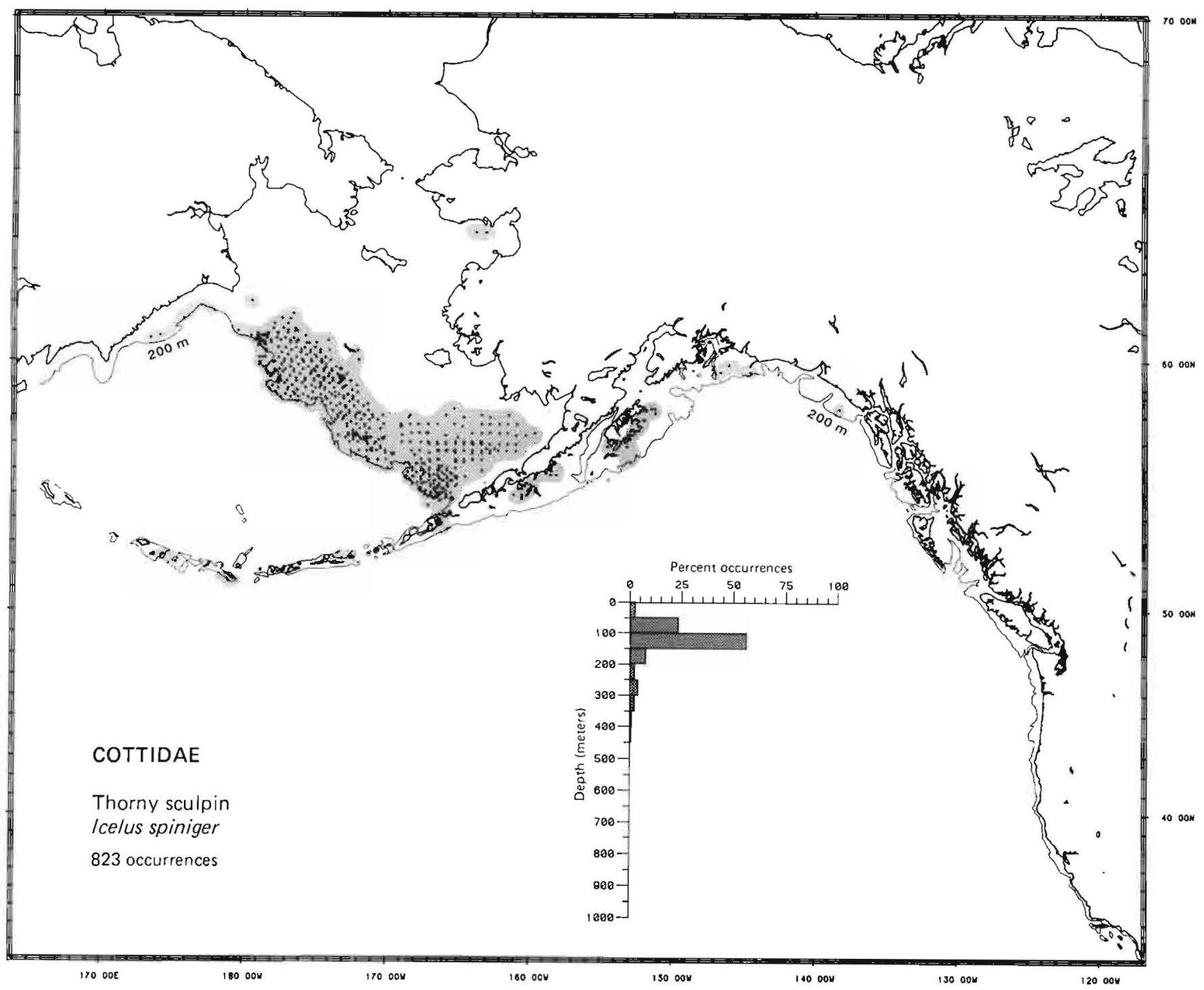


Literature Reported from northern North Korea in the Sea of Japan and Sea of Okhotsk to the Chukchi Sea, in the Commander Islands, southeast in the Bering Sea, west in the Aleutian Islands to Unalaska Island, and east to southeast Alaska (Andriyashev 1954; Wilimovsky 1964; Okada and Kobayashi 1968; Howe 1981; Eschmeyer and Herald 1983), at depths of 2 to 550 m (Neelov 1979).

Survey data Found from off Glubokaya Bay (on the Korak Coast in the western Bering Sea) north to Kotzebue Sound in the Chukchi Sea, southeast in the eastern Bering Sea to Unalaska Island, and east to Kodiak Island. Depth range 25 to $475 \mathrm{~m}$, most frequently (52.0\% of occurrences) on the inner shelf at depths $<50 \mathrm{~m}$, and $98.3 \%$ of occurrences from depths $<150 \mathrm{~m}$. Survey data provide a more precise distribution in the Chukchi and eastern Bering Seas and a better description of depth preference, but do not otherwise expand the known range of the species.

\section{Conclusions}

Zoogeography Arctic-northern boreal Pacific

Life zone Inner shelf-outer shelf (inner shelf)

Range From the Sea of Japan and Sea of Okhotsk and from southeast Alaska and Unalaska Island north to the Chukchi Sea Depth $\quad 2$ to $550 \mathrm{~m}$

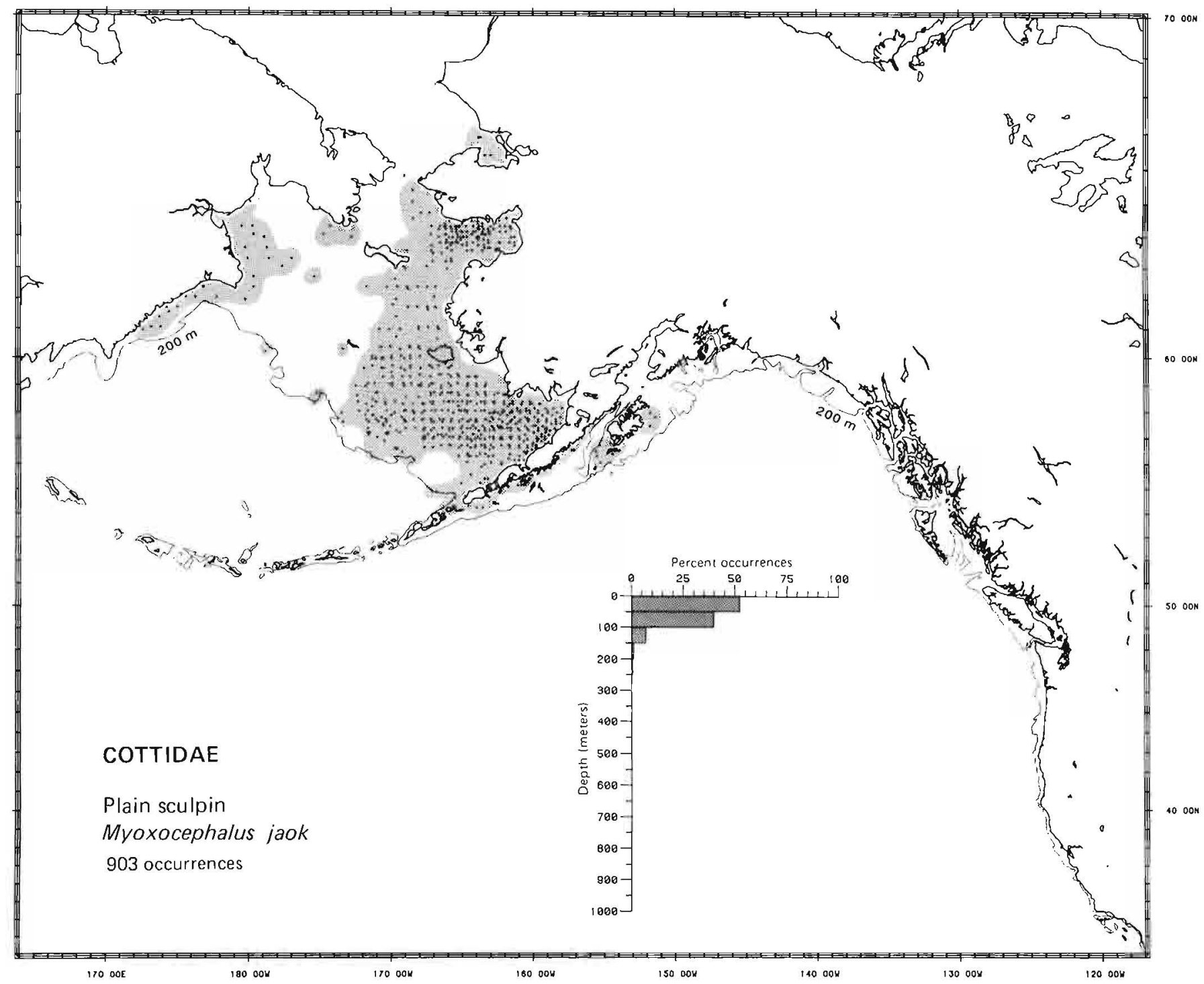


Literature Reported from the eastern Sea of Japan to the Commander Islands (but not in the Sea of Okhotsk), east along the Aleutians, north in the Bering Sea to the Pribilof Islands, and southeast to Puget Sound, Washington (Wilimovsky 1964; Quast and Hall 1972; Eschmeyer and Herald 1983), at depths of 0 to $320 \mathrm{~m}$ (Neelov 1979).

Survey data Found from Cape Olyutorski in the western Bering Sea north to off Cape Shpanberga in the Anadyr Gulf, southeast in the eastern Bering Sea to the Alaska Peninsula, west in the Aleutian Islands to Attu Island, and east to Cape Saint Elias in the northern Gulf of Alaska. Depth range 25 to $775 \mathrm{~m}$, most frequently (46.5\% of occurrences) on the middle shelf between 50 and $100 \mathrm{~m}$, and $96.8 \%$ of occurrences from depths $<250 \mathrm{~m}$. Survey data extend the known range to the north in the Bering Sea and provide a new maximum depth record. It is possible that some Bering Sea records of this species may actually be records of either the warty sculpin, Myoxocephalus verrucosus, or the plain sculpin, Myoxocephalus jaok.

\section{Conclusions}

Zoogeography Kurile-Aleutian

Life zone Inner shelf-mesobenthal (middle shelf)

Range From the eastern Sea of Japan to Cape Shpanberga in the Anadyr Gulf (but not in the Sea of Okhotsk), Bering Sea, west throughout the Aleutians, and southeast to Puget Sound, Washington

Depth 0 to $775 \mathrm{~m}$

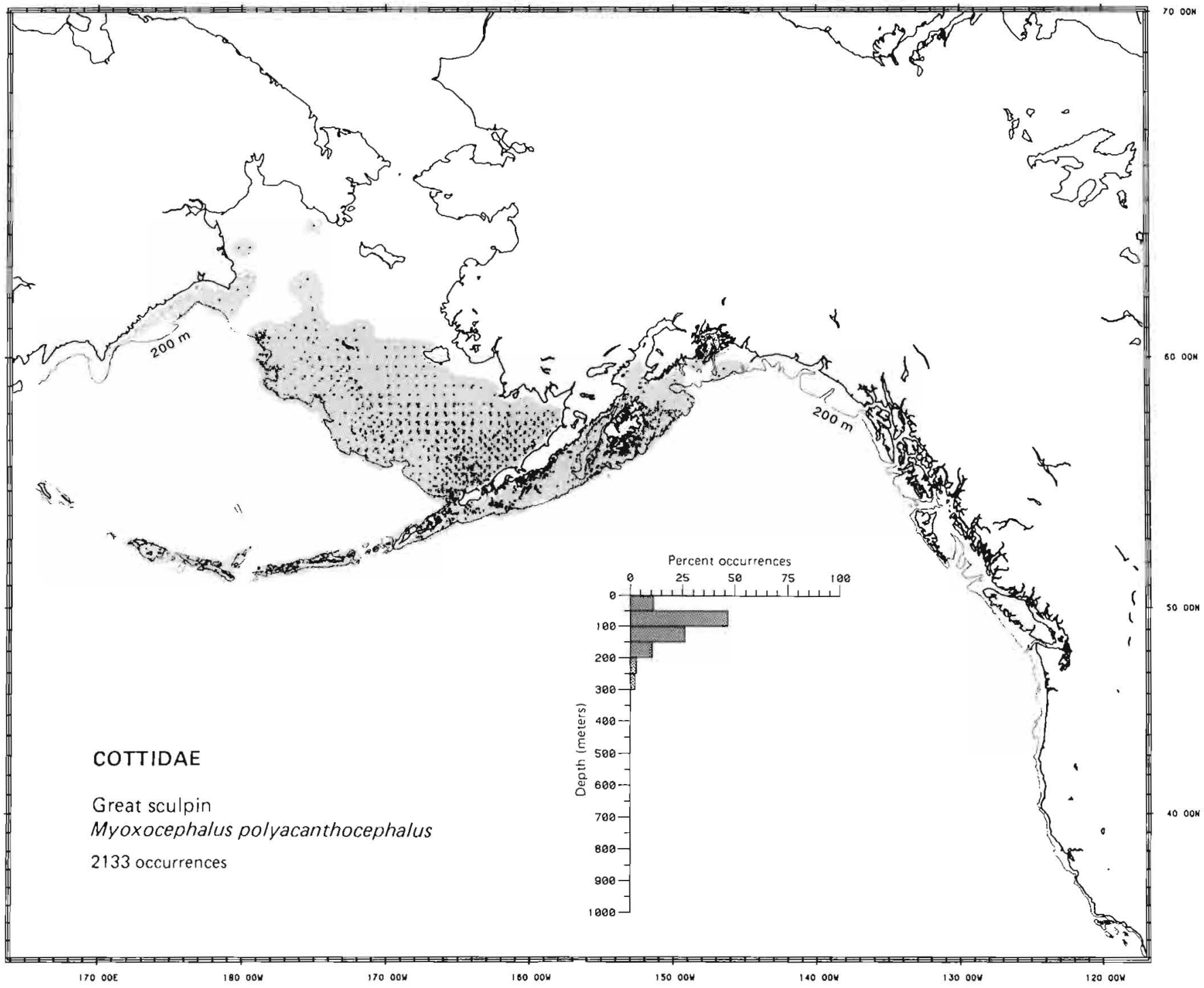


Taxonomic comment The warty sculpin is the Pacific population of the shorthorn sculpin, Myoxocephalus scorpius (Linnaeus 1758), of Robins (1980). Neelov (1979), the most recent revision of this genus, regarded this population as a distinct species, Myoxocephalus verrucosus. This species has also been called Myoxocephalus groenlandicus (Cuvier and Valenciennes 1829) and Myoxocephalus scorpius groenlandicus in recent surveys in the Bering Sea and Gulf of Alaska.

Literature Reported from the Laptev and Chukchi Seas in the western Arctic, south in the Bering Sea to the Kamchatka Gulf, along the Aleutian Islands to Adak Island, and east to British Columbia (Wilimovsky 1964; Neelov 1979), at depths of 0 to $550 \mathrm{~m}$ (Neelov 1979).

Survey data Found from Point Hope, Alaska, in the Chukchi Sea, south in the eastern Bering Sea to Barykova Point, Siberia, and throughout the middle shelf to the southeast, and to Portlock Bank south of the Kenai Peninsula in the Gulf of Alaska. Depth range 25 to $275 \mathrm{~m}$, most frequently (50.1\% of occurrences) on the middle shelf between 50 and $100 \mathrm{~m}$, and $95.5 \%$ of occurrences from depths $<150 \mathrm{~m}$. Survey data do not expand the known range but provide a more precise distribution in the Bering Sea and a more precise description of depth preference.

\section{Conclusions}

\section{Zoogeography Arctic-Aleutian}

Life zone Inner shelf-outer shelf (middle shelf)

Range From the Kamchatka Gulf, Adak Island in the Aleutian Islands, and British Columbia north to the Laptev and Chukchi Seas Depth $\quad 0$ to $550 \mathrm{~m}$

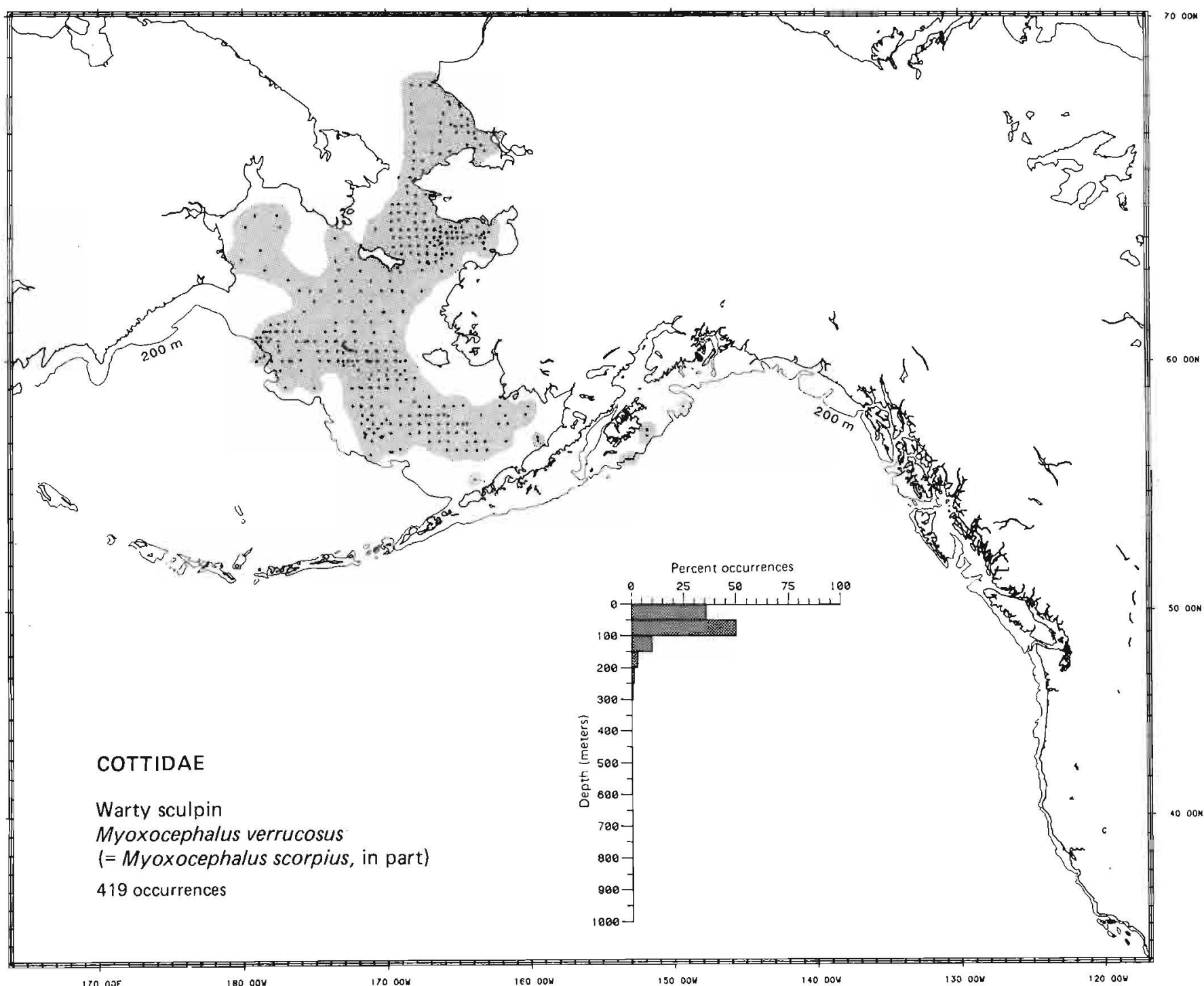


Literature Reported from Amchitka Island in the Aleutian Islands, north to the Bering Sea, and east to Kodiak Island in the Gulf of Alaska (Quast and Hall 1972; Simenstad et al. 1977; Eschmeyer and Herald 1983), at depths of 20 to $340 \mathrm{~m}$ (Fedorov $1973 \mathrm{a}$ ).

Survey data Found from off Cape Nizkiy (on the Korak Coast of the eastern Bering Sea) north to Cape Navarin, southeast in the eastern Bering Sea to Unimak Island, west in the Aleutian Islands to Agattu Island, and east in the Gulf of Alaska to North Albatross Bank off Kodiak Island. Depth range 25 to $425 \mathrm{~m}$, most frequently (43.8\% of occurrences) on the outer shelf between 100 and $150 \mathrm{~m}$, and $97.3 \%$ of occurrences from depths $<200 \mathrm{~m}$. Survey data provide new northern and western limits in the Bering Sea, extend the known limit westward in the Aleutian Islands and slightly eastward in the Gulf of Alaska, and expand its known depth range.

\section{Conclusions}

Zoogeography Aleutian

Life zone Inner shelf-outer shelf (outer shelf)

Range From Cape Nizkiy in the western Bering Sea north to Cape Navarin, southeast to Unimak Island, west in the Aleutian

Depth 20 to $425 \mathrm{~m}$

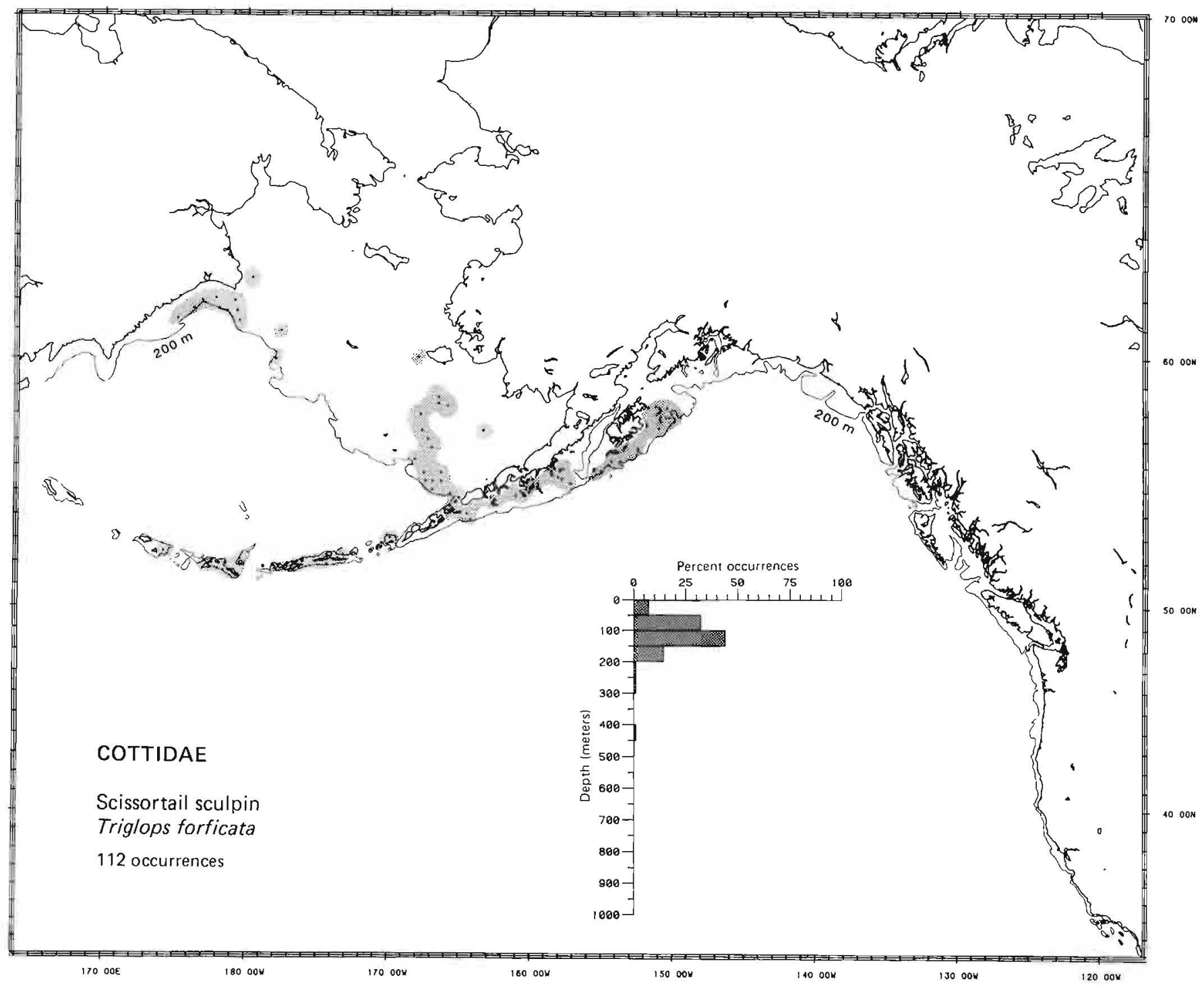


Literature Reported from the Bering Sea, west in the Aleutian Islands to Amchitka Island, and southeast to Washington (Simenstad et al. 1977; Eschmeyer and Herald 1983), at depths of 18 to 245 m (Fedorov 1973a; Eschmeyer and Herald 1983).

Survey data Found from northwest of Saint Matthew Island and north of Nunivak Island, southeast in the eastern Bering Sea to Unimak Island, and east to Hinchinbrook Island in the northern Gulf of Alaska. Depth range 25 to $275 \mathrm{~m}$, most frequently (41.0\% of occurrences) on the middle shelf between 50 and $100 \mathrm{~m}$, and $91.8 \%$ of occurrences from depths $\leqslant 150 \mathrm{~m}$. Survey data provide a more precise distribution in the Bering Sea and a new maximum depth record.

\section{Conclusions}

\section{Zoogeography Aleutian}

Life zone Inner shelf-outer shelf (middle shelf)

Range From northwest of Saint Matthew Island and Nunivak Island in the Bering Sea and from Amchitka Island in the AleuDepth $\quad 18$ to $275 \mathrm{~m}$

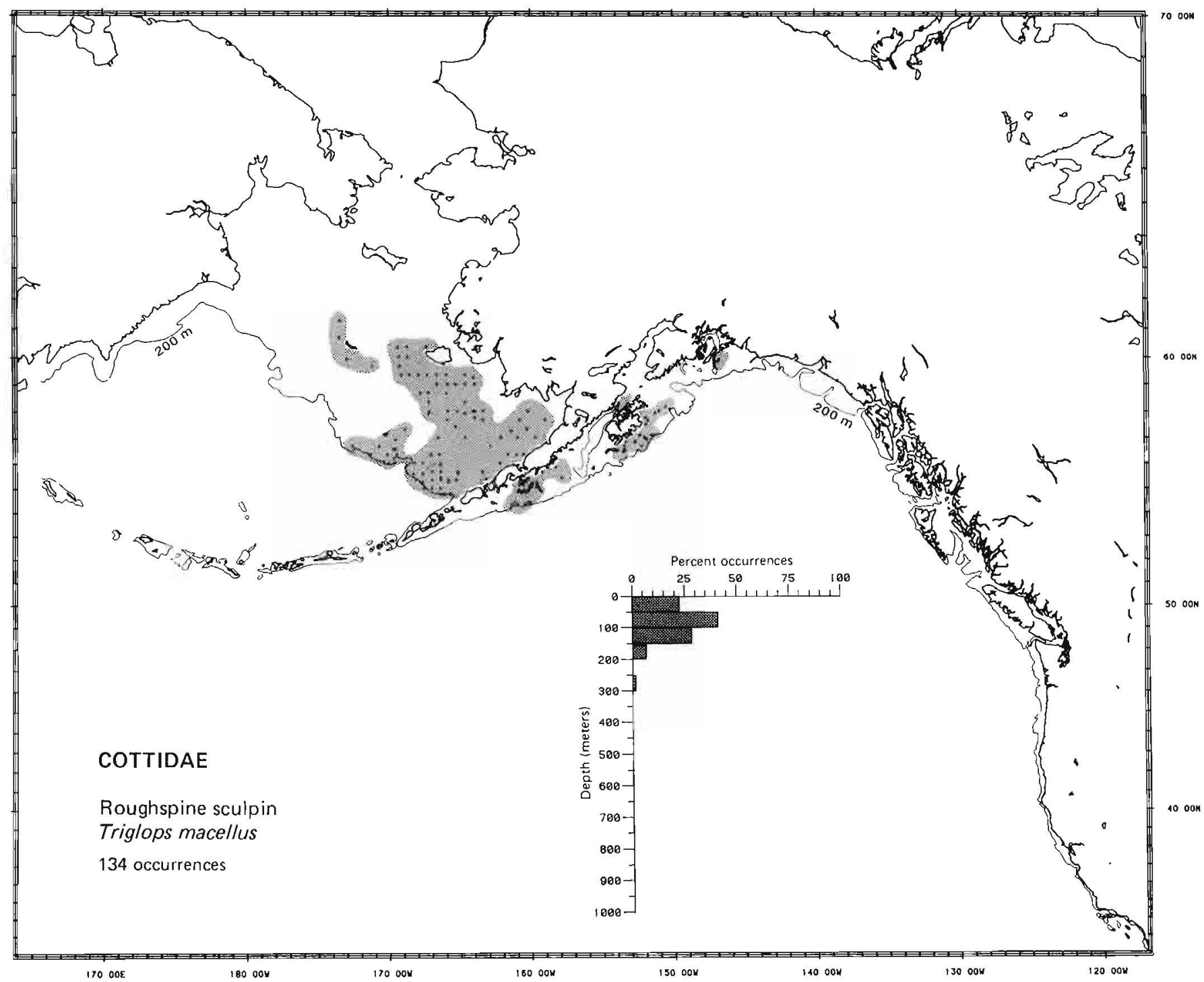


Literature Reported from the Sea of Japan off Hokkaido, Amchitka Island in the Aleutian Islands, and Puget Sound, Washington, north to the Arctic (where it is circumpolar) and south in the North Atlantic and eastern Arctic to north of Cape Cod, Massachusetts, western Greenland, Spitsbergen, and the White Sea (Andriyashev 1954; Wilimovsky 1964; Quast and Hall 1972; Hart 1973), from 4 to $482 \mathrm{~m}$ depths (Andriyashev 1954; Fedorov 1973a).

Survey data Found from off Glubokaya Bay (on the Korak Coast of the western Bering Sea) north to northeast of Cape Lisburne in the Chukchi Sea, southeast in the eastern Bering Sea to the Alaska Peninsula, west in the Aleutian Islands to Stalemate Bank, and east in the Gulf of Alaska to off Lituya Bay in southeastern Alaska. Depth range 25 to $275 \mathrm{~m}$, most frequently (45.5\% of occurrences) on the middle shelf between 50 and $100 \mathrm{~m}$, and $94.0 \%$ of occurrences from depths $<150 \mathrm{~m}$. Survey data extend the known range west in the Aleutian Islands.

\section{Conclusions}

Zoogeography Arctic-amphiboreal (western boreal Atlantic-northern boreal Pacific)

Life zone Inner shelf-outer shelf (middle shelf)

Range From the Sea of Japan, Stalemate Bank in the Aleutian Islands, and Puget Sound, Washington, north throughout the Arctic and south to Cape Cod, Massachusetts, western Greenland, Spitsbergen, and the White Sea

Depth 4 to $482 \mathrm{~m}$

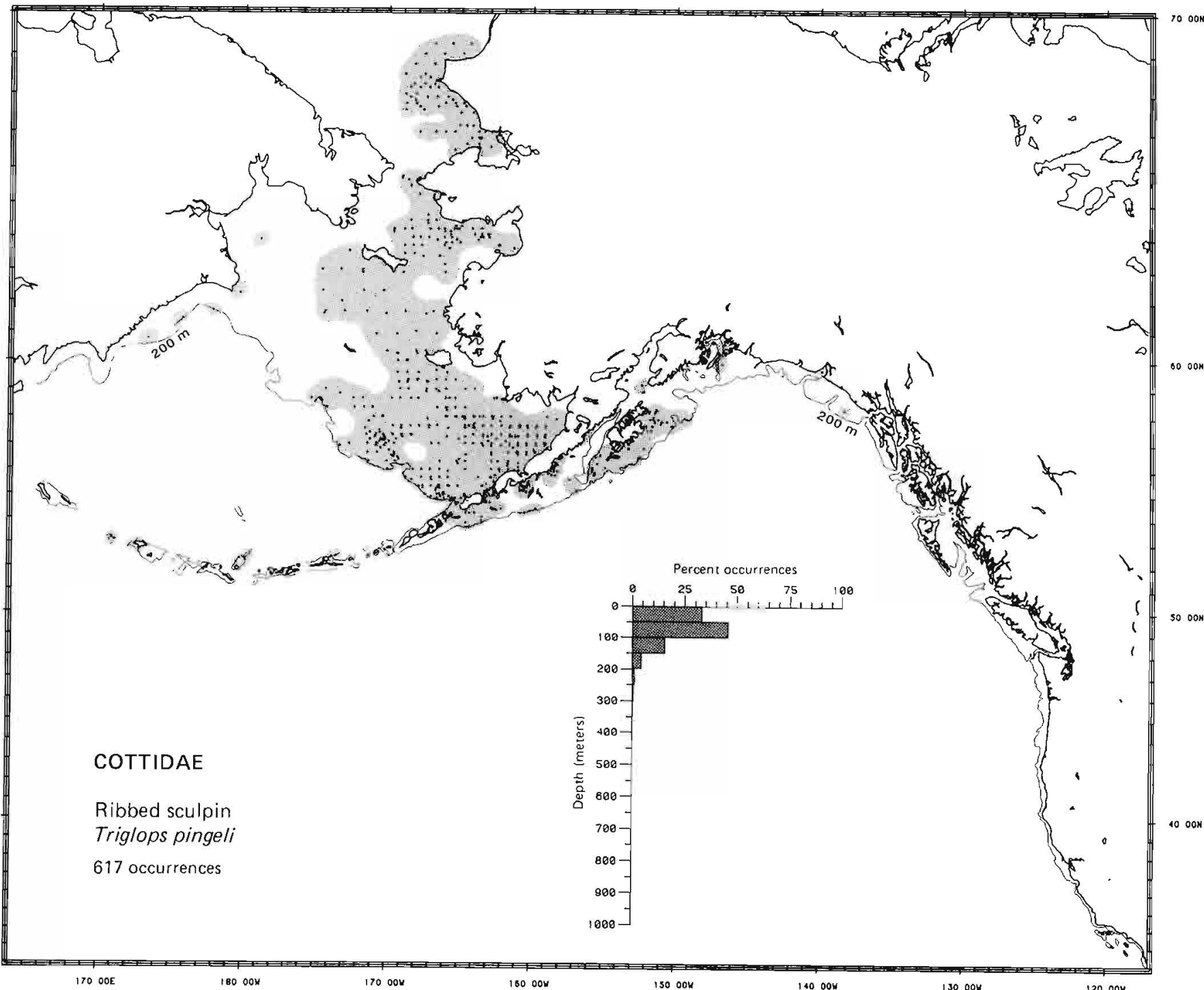


Literature Reported from Hokkaido, Japan, and the Sea of Okhotsk to Cape Olyutorski in the western Bering Sea, west along the Aleutian Islands to Attu Island, and east to southeastern Alaska (Quast and Hall 1972; Eschmeyer and Herald 1983), at depths of 50 to $310 \mathrm{~m}$ (Fedorov 1973a; Howe 1981).

Survey data Found from Navarin Canyon southeast along the outer shelf and slope of the eastern Bering Sea to the Alaska Peninsula, west in the Aleutians to Stalemate Bank and Bowers Bank, and east in the Gulf of Alaska to east of Kodiak Island. Depth range 25 to $925 \mathrm{~m}$, most frequently (23.0\% of occurrences) on the outer shelf between 150 and $200 \mathrm{~m}$, and $96.8 \%$ of occurrences from depths of 50 to $450 \mathrm{~m}$. Survey data define the range in the eastern Bering Sea, slightly extend the known range west in the Aleutian Islands, and expand the known depth range.

\section{Conclusions}

\section{Zoogeography Northern boreal Pacific}

Life zone Middle shelf-mesobenthal (outer shelf)

Range From Hokkaido, Japan, and the Sea of Okhotsk north to Navarin Canyon in the Bering Sea, west to Stalemate Bank in the Aleutian Islands, and east to southeastern Alaska

Depth 25 to $925 \mathrm{~m}$

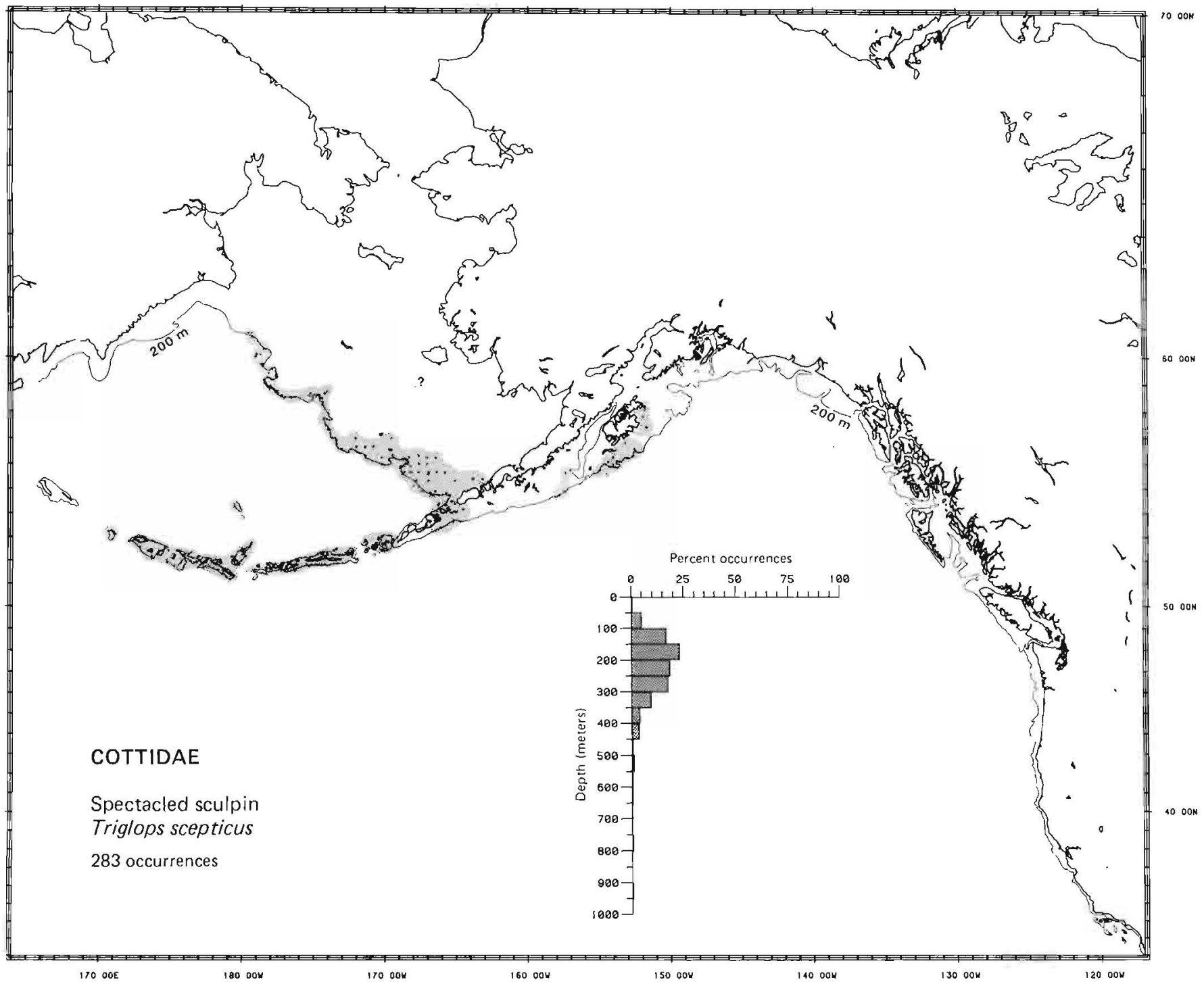


Literature Reported from Salt Point in northern California to San Cristobal Bay, Baja California Sur, and in the Gulf of California (Miller and Lea 1972), at depths of 8 to $229 \mathrm{~m}$ (Howe 1981; Eschmeyer and Herald 1983).

Survey data Found from Point Delgada, California, to Oxnard, California. Depth range 75 to $175 \mathrm{~m}$, most frequently (59.6\% of occurrences) on the middle shelf between 50 and $100 \mathrm{~m}$, and $99.0 \%$ of occurrences between depths of 50 and $150 \mathrm{~m}$. Survey data extend the known range to the north.

\section{Conclusions}

Zoogeography Oregonian-Californian

Life zone Middle shelf-outer shelf (middle shelf)

Range From Point Delgada, California, to San Cristobal Bay, Baja California Sur, and in the Gulf of California

Depth $\quad 8$ to $229 \mathrm{~m}$

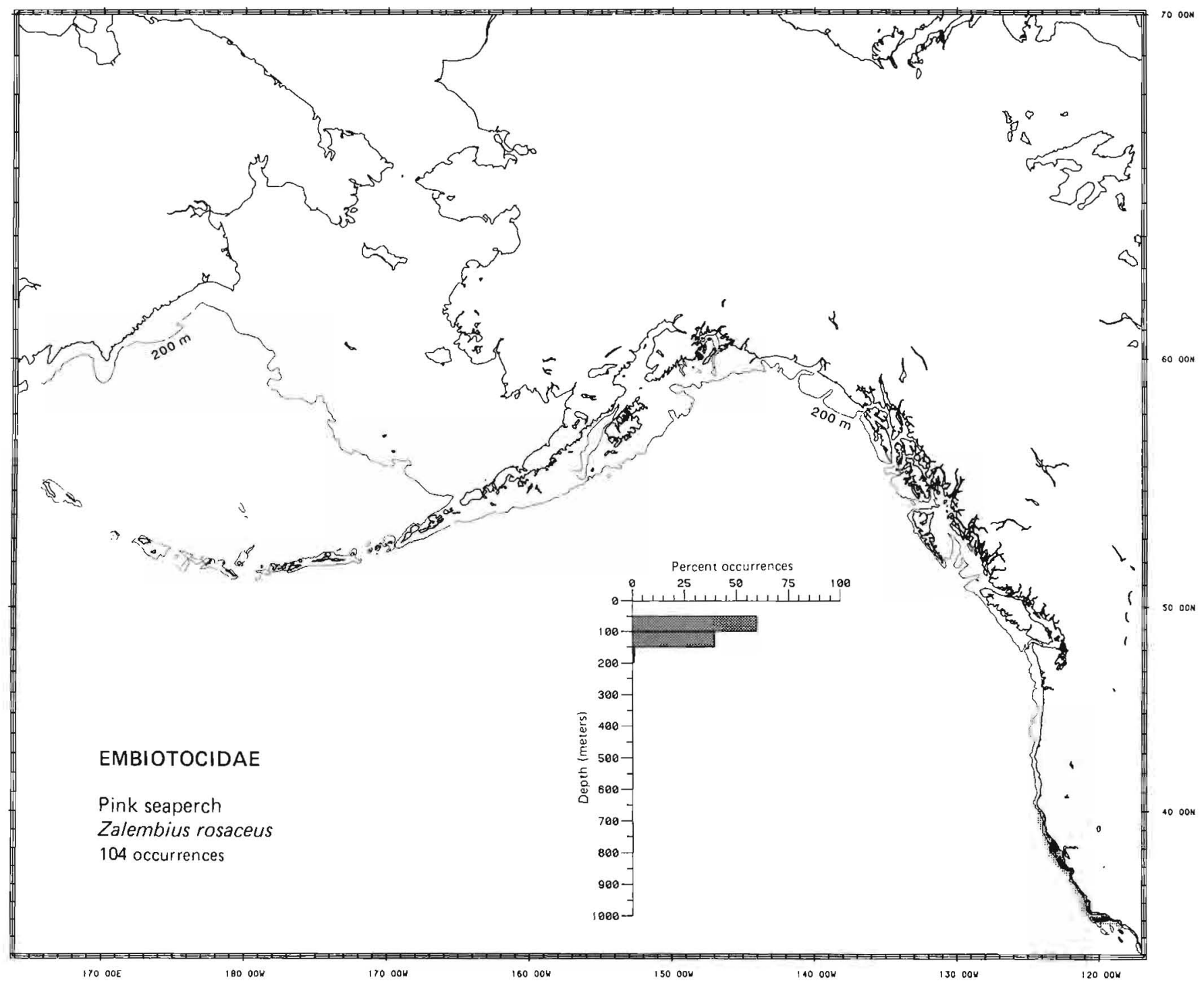


Literature Reported from eastern Kamchatka and the Commander Islands to the East Siberian Sea in the Arctic, south through the Bering Sea, west in the Aleutian Islands to Amchitka Island, and east to Washington (Quast and Hall 1972; Simenstad et al. 1977; Eschmeyer and Herald 1983), at depths of 0 to $380 \mathrm{~m}$ (Fedorov 1973a; Howe 1981).

Survey data Found from Navarin Canyon on the northwestern slope of the eastern Bering Sea, southeast along the outer shelf and slope to the Alaska Peninsula and Unimak Island, west in the Aleutian Islands to Stalemate Bank, and east to Cape Spencer in southeast Alaska. Depth range 25 to $825 \mathrm{~m}$, most frequently ( $54.0 \%$ of occurrences) on the outer shelf between 100 to $150 \mathrm{~m}$, and $95.4 \%$ of occurrences from depths of 50 to $250 \mathrm{~m}$. Survey data extend the known range west in the Aleutian Islands and provide a new depth record.

\section{Conclusions}

Zoogeography Arctic-Aleutian

Life zone Middle shelf-mesobenthal (outer shelf)

Range From eastern Kamchatka and the Commander Islands, Stalemate Bank in the Aleutian Islands, and Washington north

Depth $\quad 0$ to $825 \mathrm{~m}$

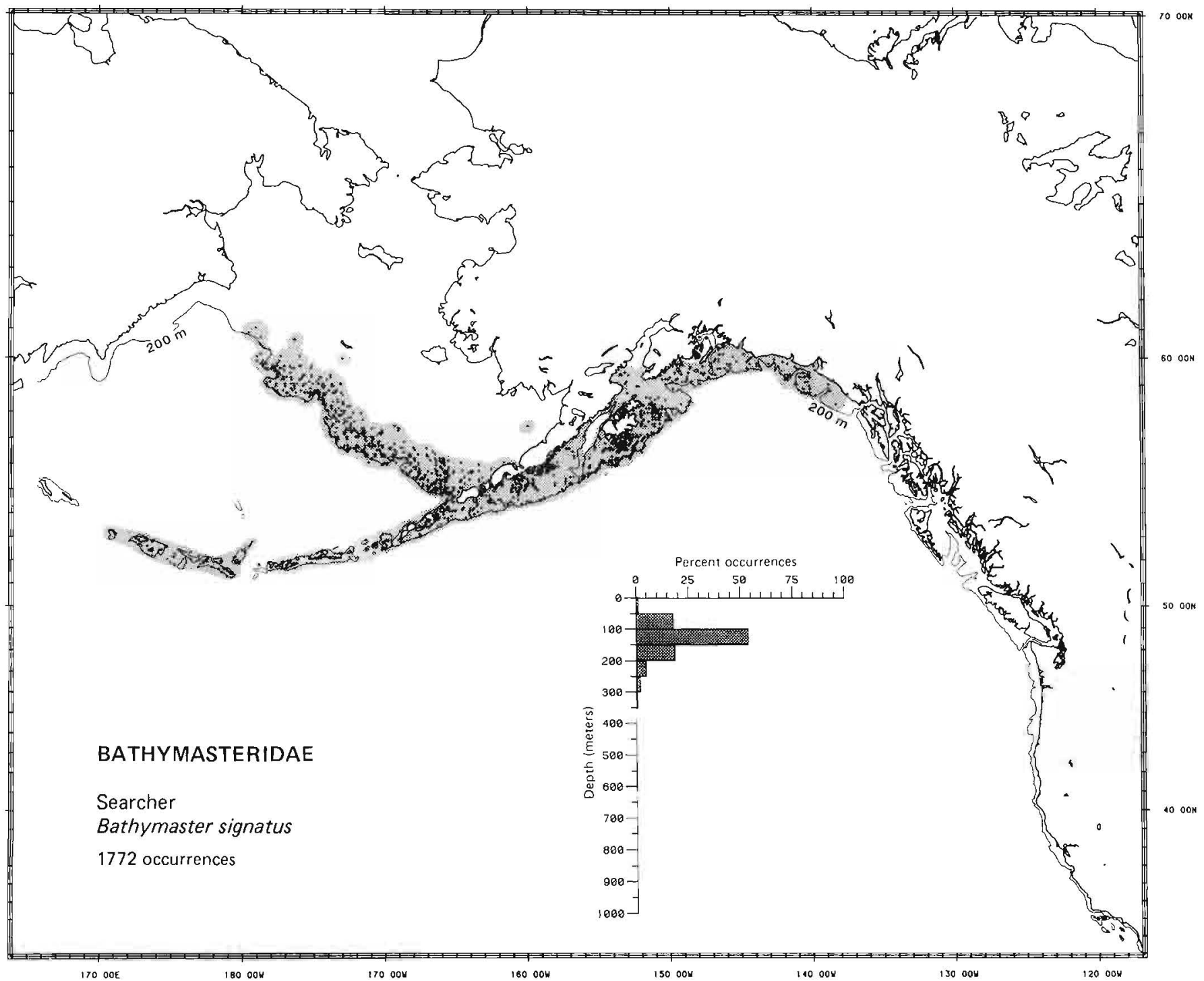


Literature Reported from the Bering Sea and Amchitka Island in the Aleutian Islands to Monterey, California (Miller and Lea 1972; Simenstad et al. 1977), at depths of 3 to $180 \mathrm{~m}$ (Howe 1981; Eschmeyer and Herald 1983).

Survey data Found from Pribilof Canyon in the southeastern Bering Sea and Unalaska Island in the Aleutian Islands east to off Yakutat Bay in southeastern Alaska. Depth range 25 to $275 \mathrm{~m}$, most frequently $(51.2 \%$ of occurrences) on the outer shelf between 100 and $150 \mathrm{~m}$, and $96.0 \%$ of occurrences from depths $\leqslant 200 \mathrm{~m}$. Survey data provide a more precise range in the Bering Sea and a new maximum depth record.

\section{Conclusions}

Zoogeography Eastern boreal Pacific

Life zone Inner shelf-outer shelf (outer shelf)

Range From Pribilof Canyon in the Bering Sea and Amchitka Island in the Aleutian Islands to Monterey, California

Depth $\quad 3$ to $275 \mathrm{~m}$

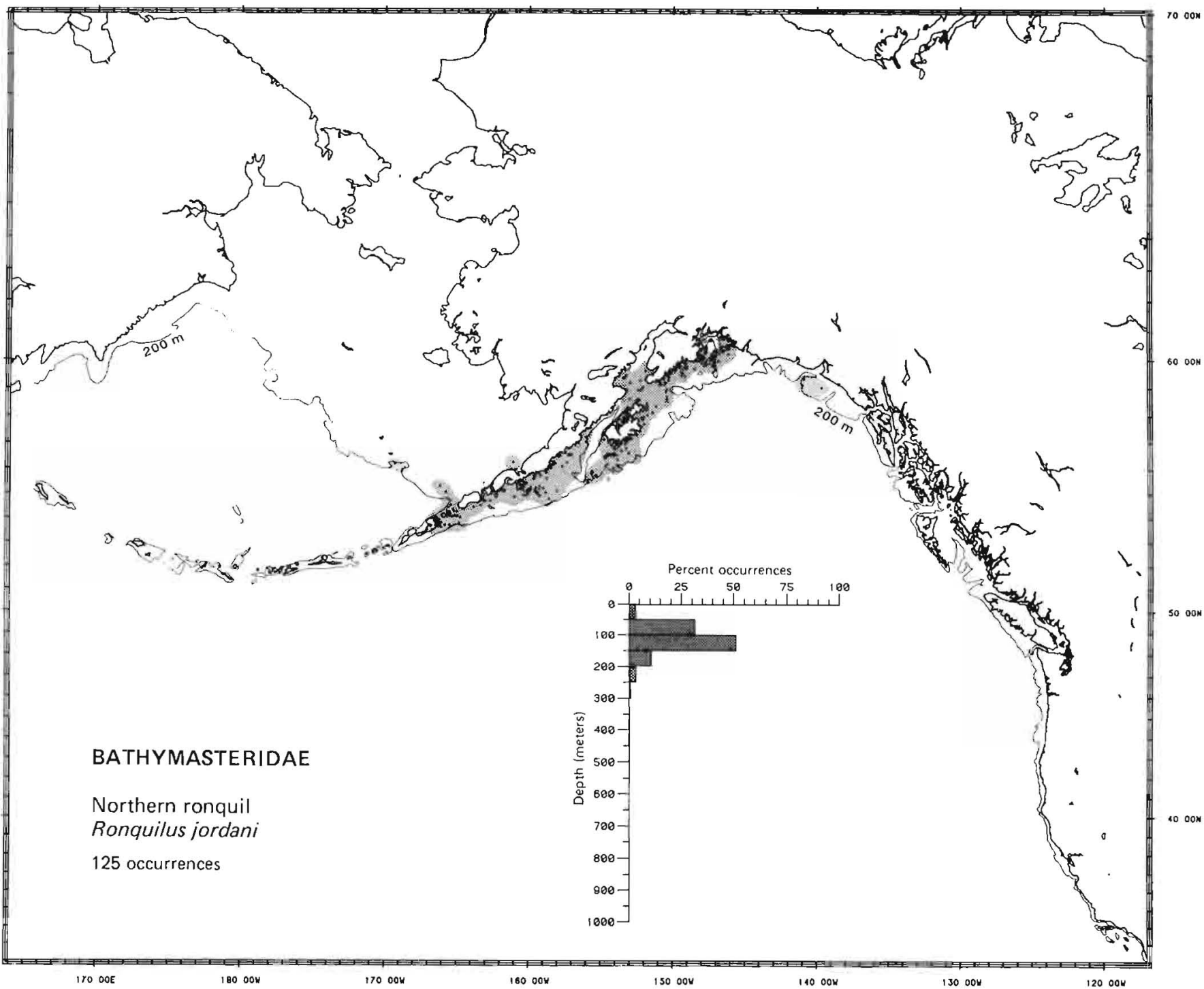


Literature Reported from Sakhalin, U.S.S.R., in the Sea of Okhotsk to Olyutorski Bay in the western Bering Sea and southeast to the Coronado Islands, Baja California (Miller and Lea 1972; Quast and Hall 1972; Hart 1973), at depths of 199 to 1829 m (Eschmeyer and Herald 1983).

Survey data Found from Navarin Canyon on the northwest slope of the eastern Bering Sea southeast to the slope north of Akutan Island and west in the Aleutian Islands to Attu Island and the Ulm Plateau. Depth range 25 to $1025 \mathrm{~m}$, most frequently (13.2\% of occurrences) on the bathybenthal slope between 550 and $600 \mathrm{~m}$, and $95.5 \%$ of occurrences from depths of 350 to $950 \mathrm{~m}$. Survey data provide a new northern limit in the eastern Bering Sea, extend the known range west in the Aleutian Islands, and provide a new shallow depth record. The occurrence of this species on the middle shelf in the southeastern Bering Sea appears to be anomalous.

\section{Conclusions}

Zoogeography Northeastern boreal Pacific

Life zone Mesobenthal-bathybenthal (bathybenthal)

Range From Sakhalin to Navarin Canyon in the Bering Sea, west in the Aleutian Islands to Attu Island, and southeast to the Coronado Islands, Baja California

Depth 199 (possibly 25) to $1829 \mathrm{~m}$

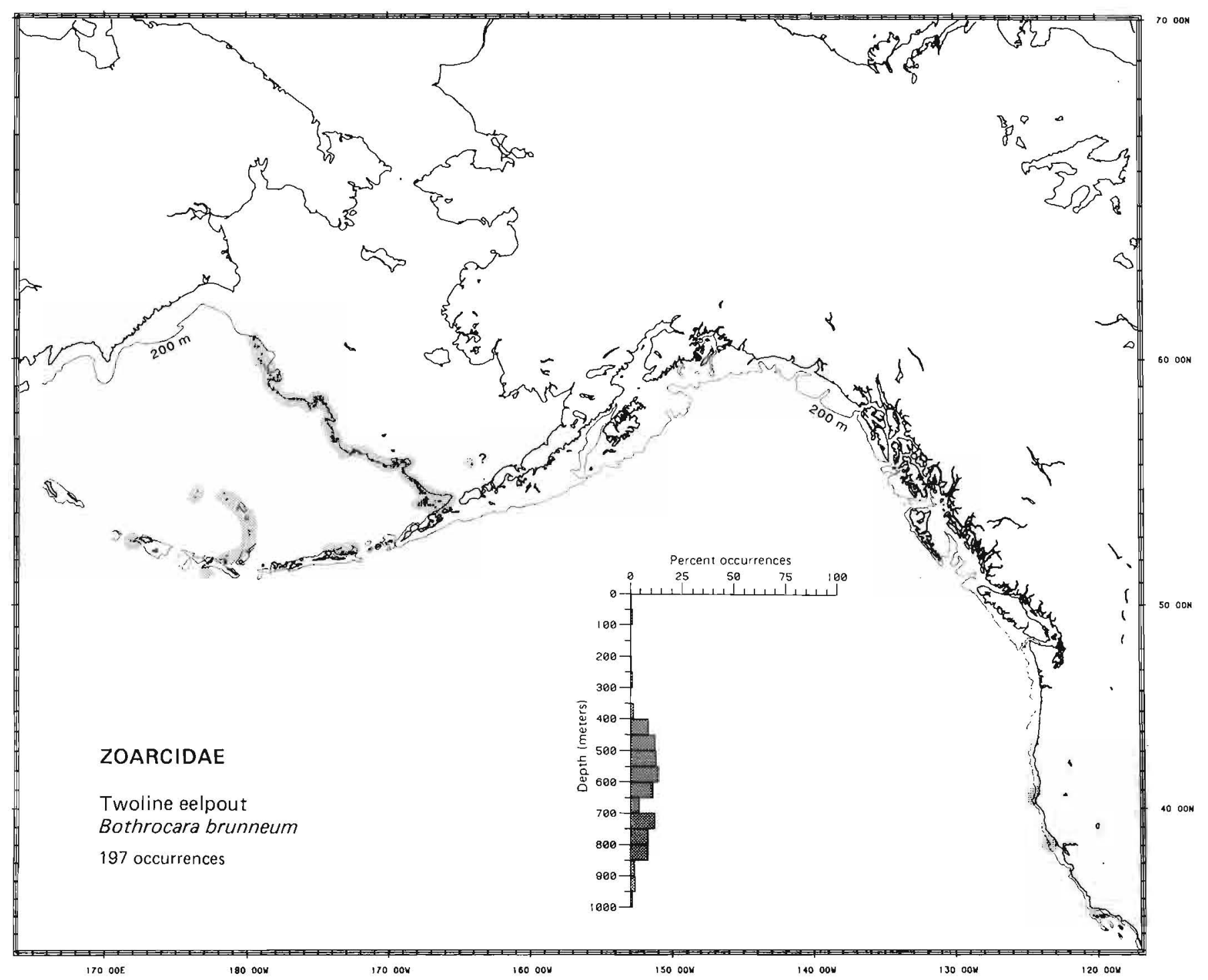


Literature Reported from the Sea of Okhotsk to the Anadyr Gulf in the Bering Sea, in the Aleutian Islands, southeast to Oregon (Andriyashev 1954; Okada and Kobayashi 1968; Eschmeyer and Herald 1983), at depths of 27 to $973 \mathrm{~m}$ (Fedorov 1973a; Eschmeyer and Herald 1983).

Survey data Found from east of Cape Navarin, southeast along the outer shelf and slope in the eastern Bering Sea to Unimak Island, west in the Aleutian Islands to Unalaska Island, and southeast to Fort Bragg, California. Depth range 25 to $875 \mathrm{~m}$, most frequently (58.5\% of occurrences) on the outer shelf between 100 and $150 \mathrm{~m}$, and $96.0 \%$ of occurrences from depths $\leqslant 250 \mathrm{~m}$. There is one highly questionable record of this species from Kotzebue Sound in the Chukchi Sea. Survey data extend the known geographic range west in the Aleutian Islands and south to California, and provide a slightly shallower depth record.

\section{Conclusions}

Zoogeography Northeastern boreal Pacific

Life zone Inner shelf-mesobenthal (outer shelf)

Range From the Sea of Okhotsk to the Anadyr Gulf in the Bering Sea, west in the Aleutian Islands to Unalaska Island, and southeast to Fort Bragg, California

Depth 25 to $973 \mathrm{~m}$

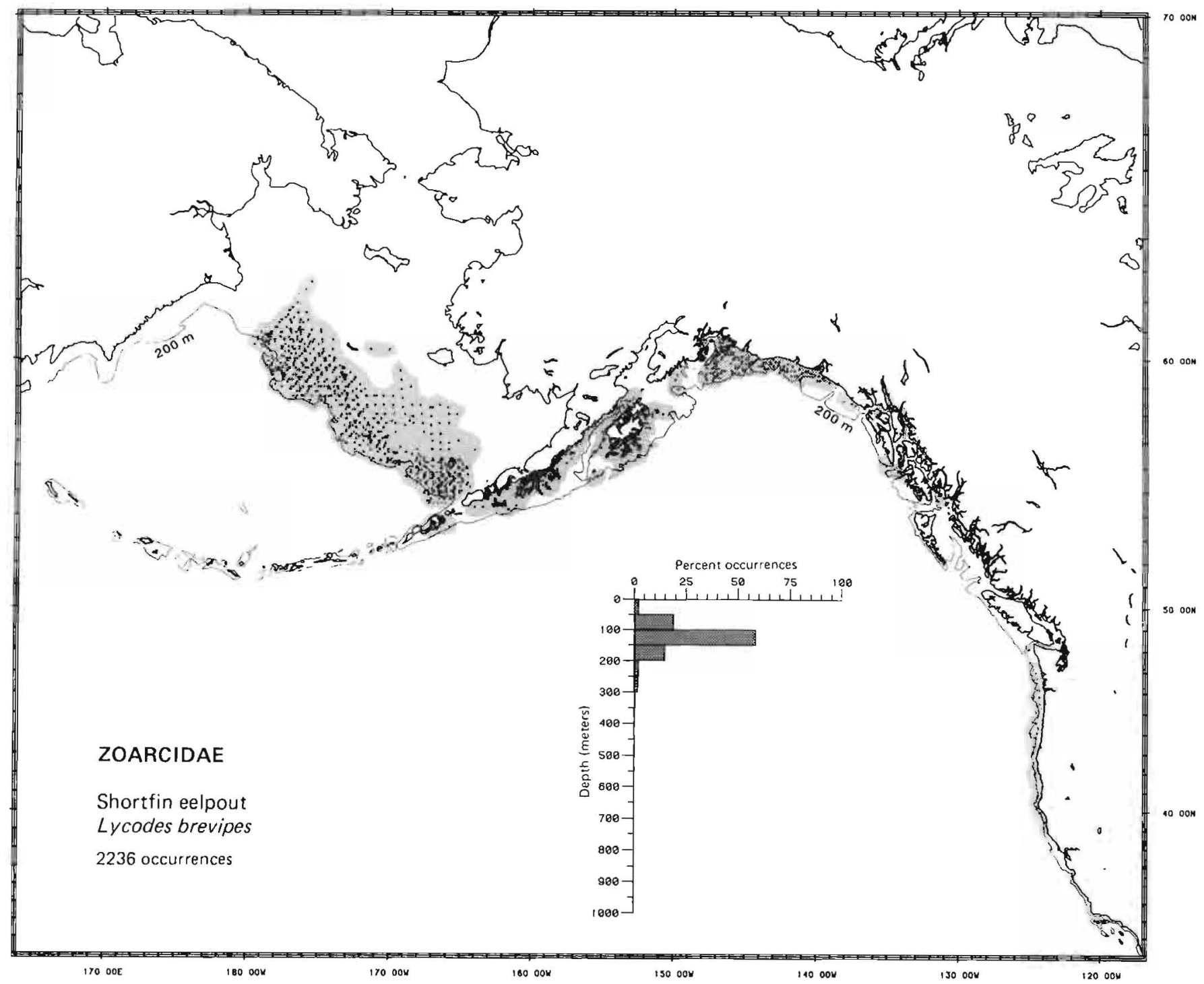


Taxonomic comment The ebony eelpout, Lycodes concolor, as construed by E. M. Anderson (Dep. Ichthyol., Calif. Acad. Sci., San Francisco, CA 94118, pers. commun. April 1984), includes both L. andriashevi Fedorov 1966 and L. soldatovi Taranets and Andriyashev 1935 as junior synonyms. All records of the species in this survey were identified in the field as $L$. soldatovi.

Literature Reported from the Sea of Okhotsk to Cape Olyutorski in the western Bering Sea and southeast to the eastern Bering Sea (Fedorov 1966; Quast and Hall 1972), at depths of 42 to $550 \mathrm{~m}$ (Howe 1981).

Survey data Found from Navarin Canyon on the northwest slope of the eastern Bering Sea southeast to the slope north of Akutan Island, and west along the Aleutian Islands to Stalemate Bank and Bowers Bank. Depth range 175 to $1025 \mathrm{~m}$, most frequently (15.3\% of occurrences) on the bathybenthal slope between 550 and $600 \mathrm{~m}$, and $96.3 \%$ of occurrences from depths of 250 to $850 \mathrm{~m}$. Survey data provide a more precise distribution of this species in the eastern Bering Sea, extend its known range west along the Aleutian Islands, and provide a new maximum depth record.

\section{Conclusions}
Zoogeography Northern boreal Pacific
Life zone Mesobenthal-bathybenthal (bathybenthal)
Range From the Sea of Okhotsk north to Navarin Canyon in the Bering Sea, southeast to Akutan Island, and west to Stalemate
Depth $\quad 42$ to $1025 \mathrm{~m}$

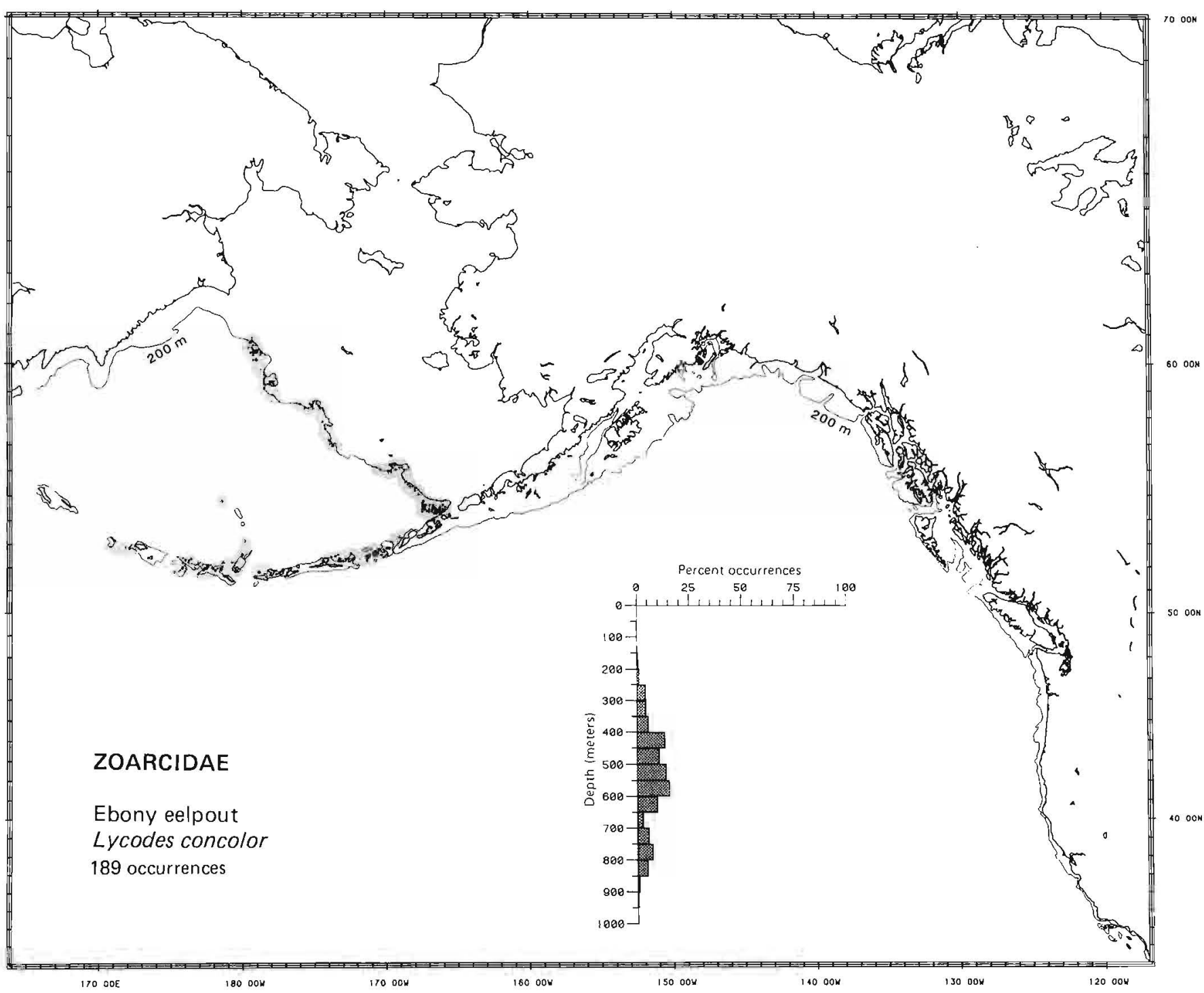


Taxonomic comment The bigfin eelpout is Aprodon cortezianus in Robins (1980), but Eschmeyer and Herald (1983) and E. M. Anderson (Dep. Ichthyol., Calif. Acad. Sci., San Francisco, CA 94118, pers. commun. April 1984) place this species in the genus Lycodes.

Literature Reported from Queen Charlotte Sound, British Columbia, to San Diego, California (Miller and Lea 1972), at depths of 73 to $800 \mathrm{~m}$ (Howe 1981; Eschmeyer and Herald 1983).

Survey data Found from Prince of Wales Island, Alaska, south to the Santa Barbara Channel, California. There is a highly questionable record of this species from west of Saint Matthew Island in the eastern Bering Sea and a questionable record off Stepovak Bay on the Alaska Peninsula in the Gulf of Alaska. Found at depths of 75 to $475 \mathrm{~m}$, most frequently $(21.1 \%$ of occurrences) on the mesobenthal slope between 300 and $350 \mathrm{~m}$, and $98.6 \%$ of occurrences from depths of 100 to $450 \mathrm{~m}$. Survey data extend the known geographic range to the north to at least Prince of Wales Island, Alaska.

\section{Conclusions}

Zoogeography Eastern boreal Pacific

Life zone Outer shelf-mesobenthal (mesobenthal)

Range From Prince of Wales Island, Alaska (or, questionably, from Saint Matthew Island in the Bering Sea and Stepovak Depth $\quad \begin{array}{ll}\text { Bay in the west } 800 \mathrm{~m}\end{array}$

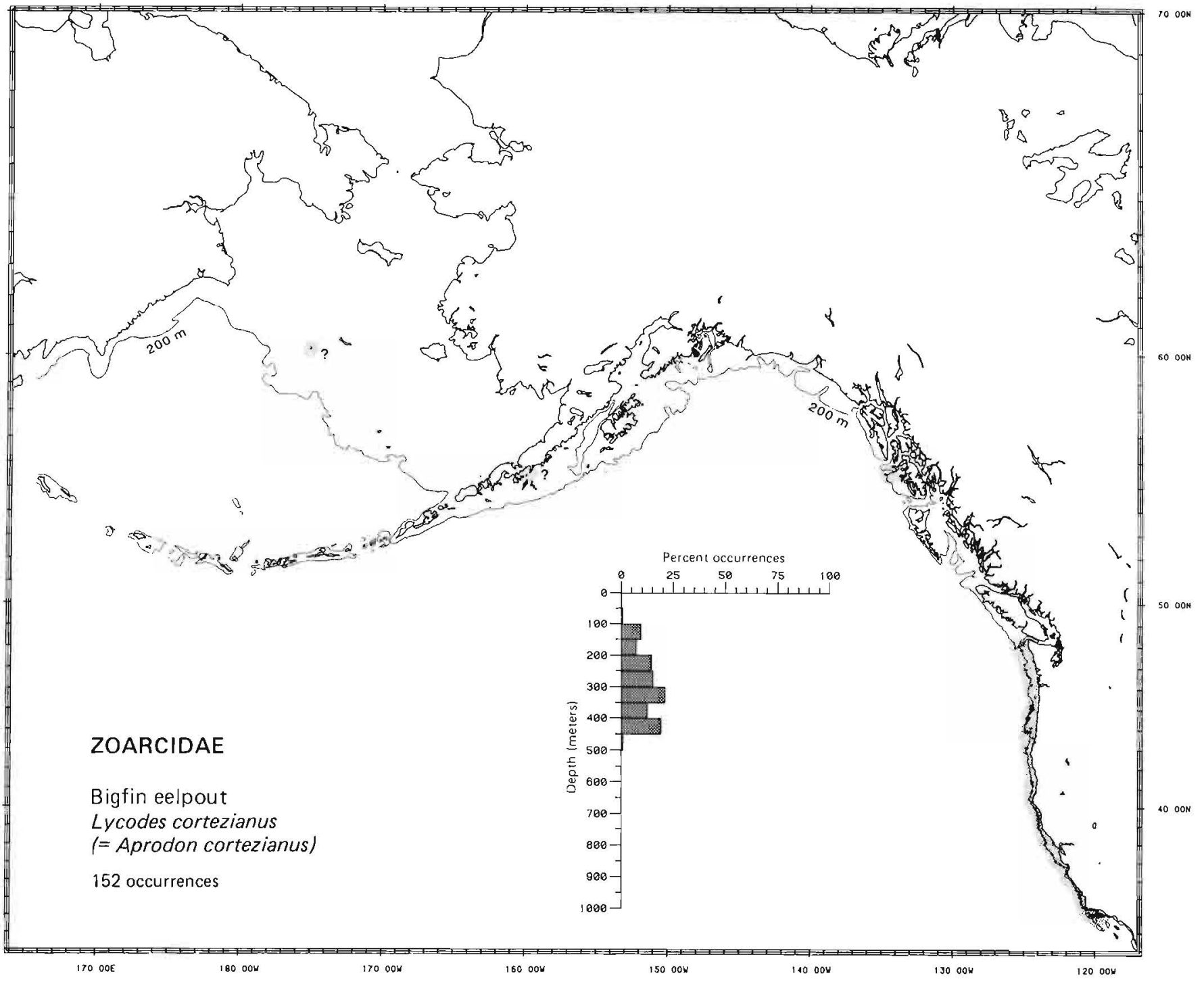


Literature Reported from the Sea of Japan (and the Sea of Okhotsk) to the northwest Bering Sea and south to San Diego, California (Shmidt 1950; Miller and Lea 1972; Hart 1973), at depths of 13 to $1300 \mathrm{~m}$ (Howe 1981; Eschmeyer and Herald 1983).

Survey data Found from Navarin Canyon on the northwest slope of the eastern Bering Sea southeast to Akutan Island, west along the Aleutian Islands to Attu Island and Bowers Bank, and southeast to the Santa Barbara Channel, California. Depth range 25 to $1025 \mathrm{~m}$, most frequently (13.9\% of occurrences) on the mesobenthal slope between 400 and $450 \mathrm{~m}$, and $95.6 \%$ of occurrences from depths of 100 to $850 \mathrm{~m}$. Survey data provide a more precise distribution in the Bering Sea and extend the known range west in the Aleutian Islands.

\section{Conclusions}

Zoogeography Northeastern boreal Pacific

Life zone Outer shelf-bathybenthal (mesobenthal)

Range From the Sea of Japan to Navarin Canyon in the Bering Sea, west to Attu Island in the Aleutian Islands, and southeast

Depth 13 to $1300 \mathrm{~m}$

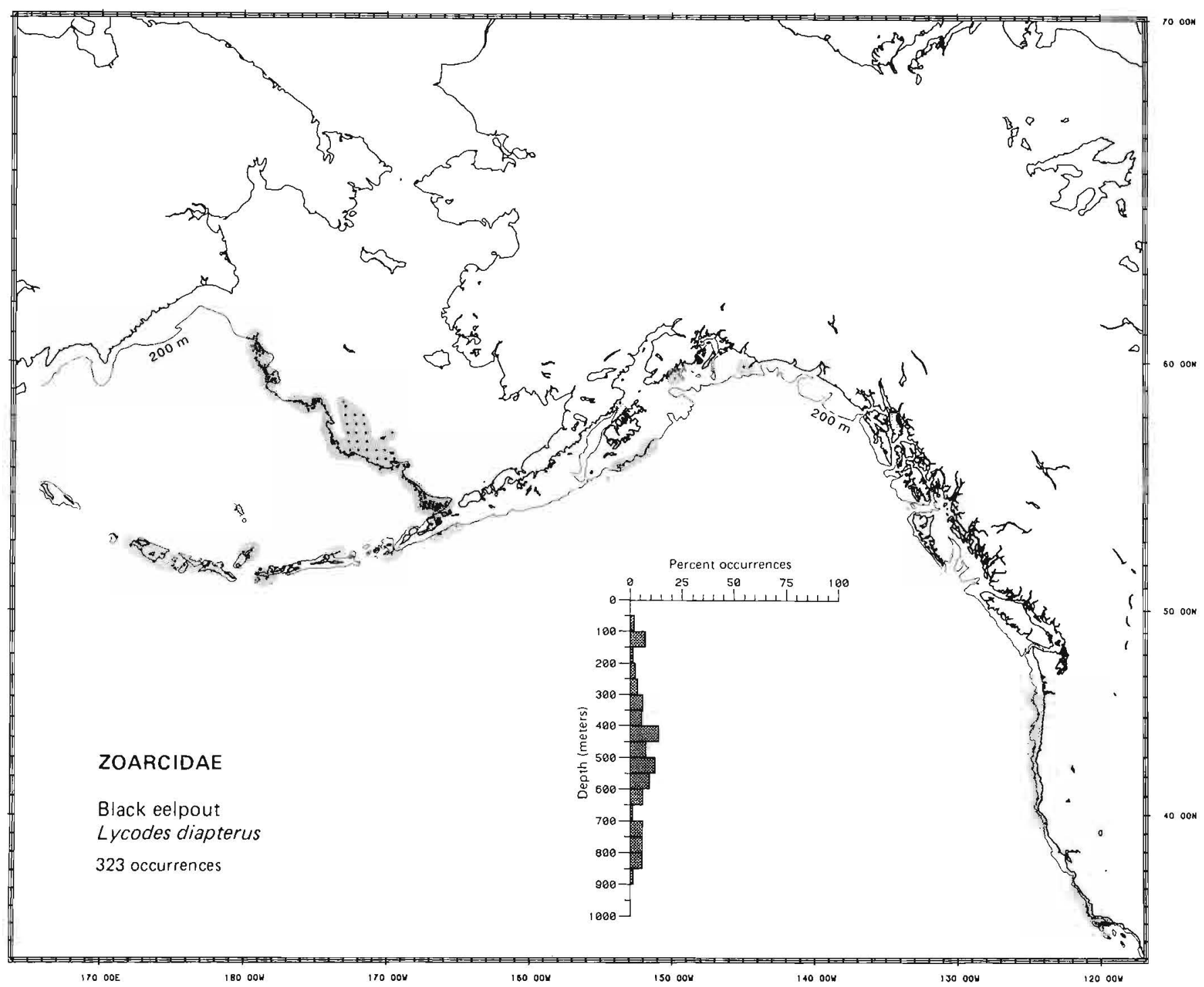


Literature Reported from Peter the Great Bay in the Sea of Japan and the Sea of Okhotsk north to the Chukchi Sea and south to Oregon (Quast and Hall 1972; Hart 1973; Eschmeyer and Herald 1983), at depths of 29 to $316 \mathrm{~m}$ (Andriyashev 1954; Fedorov 1973a).

Survey data Found from Point Hope in the Chukchi Sea, south in the eastern Bering Sea to Cape Navarin in the west and to Unimak Island in the southeast, west along the Aleutian Islands to Agattu Island, and east to Dundas Island, Dixon Entrance, British Columbia. Depth range 25 to $925 \mathrm{~m}$, most frequently (42.1\% of occurrences) on the middle shelf between 50 and $100 \mathrm{~m}$, and $95.9 \%$ of occurrences from depths $\leqslant 200 \mathrm{~m}$. Survey data extend the known range west in the Aleutian Islands and provide a new maximum depth record.

\section{Conclusions}

Zoogeography Arctic-circumboreal Pacific

Life zone Inner shelf-outer shelf (middle shelf)

Range From Peter the Great Bay in the Sea of Japan and the Sea of Okhotsk, Agattu Island in the Aleutian Islands, and Oregon north to Point Hope in the Chukchi Sea

Depth 25 to $925 \mathrm{~m}$

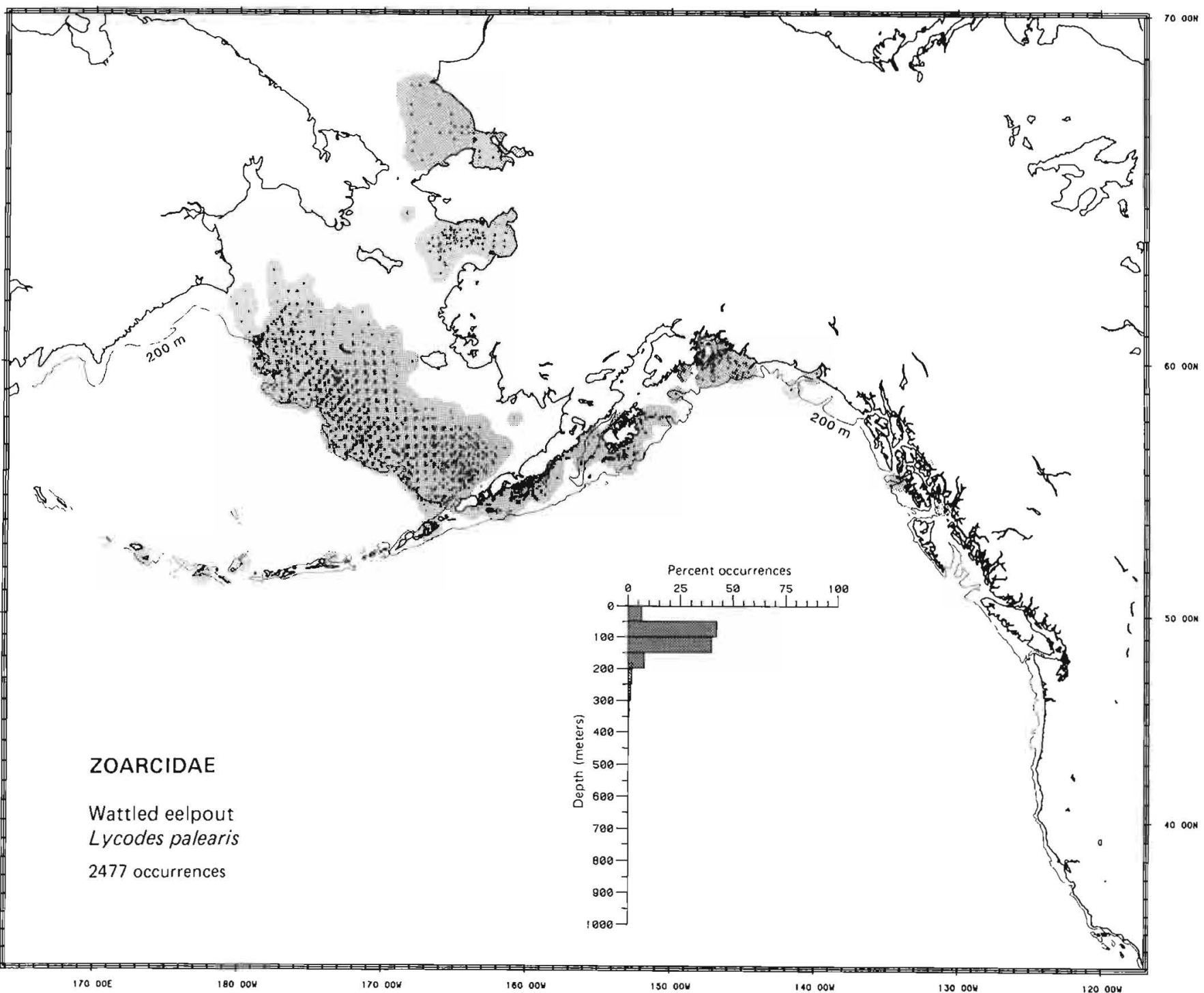


Literature Reported from southeastern Sakhalin, U.S.S.R., and the Sea of Okhotsk to the Alaskan Arctic, extending through the Bering Sea west of Saint Matthew Island (Andriyashev 1954; Quast and Hall 1972), at depths of 42 to $130 \mathrm{~m}$ (Howe 1981).

Survey data Found from off Dezhneva Bay (on the Korak Coast of the western Bering Sea) north to the northern Anadyr Gulf and western Norton Sound and southeast to west-central Bristol Bay. Depth range 25 to $175 \mathrm{~m}$, most frequently $(61.6 \%$ of occurrences) on the middle shelf between 50 and $100 \mathrm{~m}$, and $99.8 \%$ of occurrences from depths $\leqslant 150 \mathrm{~m}$. Survey data extend the known range southeast in the Bering Sea and expand the known depth range.

\section{Conclusions}

Zoogeography Arctic-Okhotsk

Life zone Inner shelf-outer shelf (middle shelf)

Range From Sakhalin, the Sea of Okhotsk, and west-central Bristol Bay in the Bering Sea north to the Alaskan Arctic Depth 25 to $175 \mathrm{~m}$

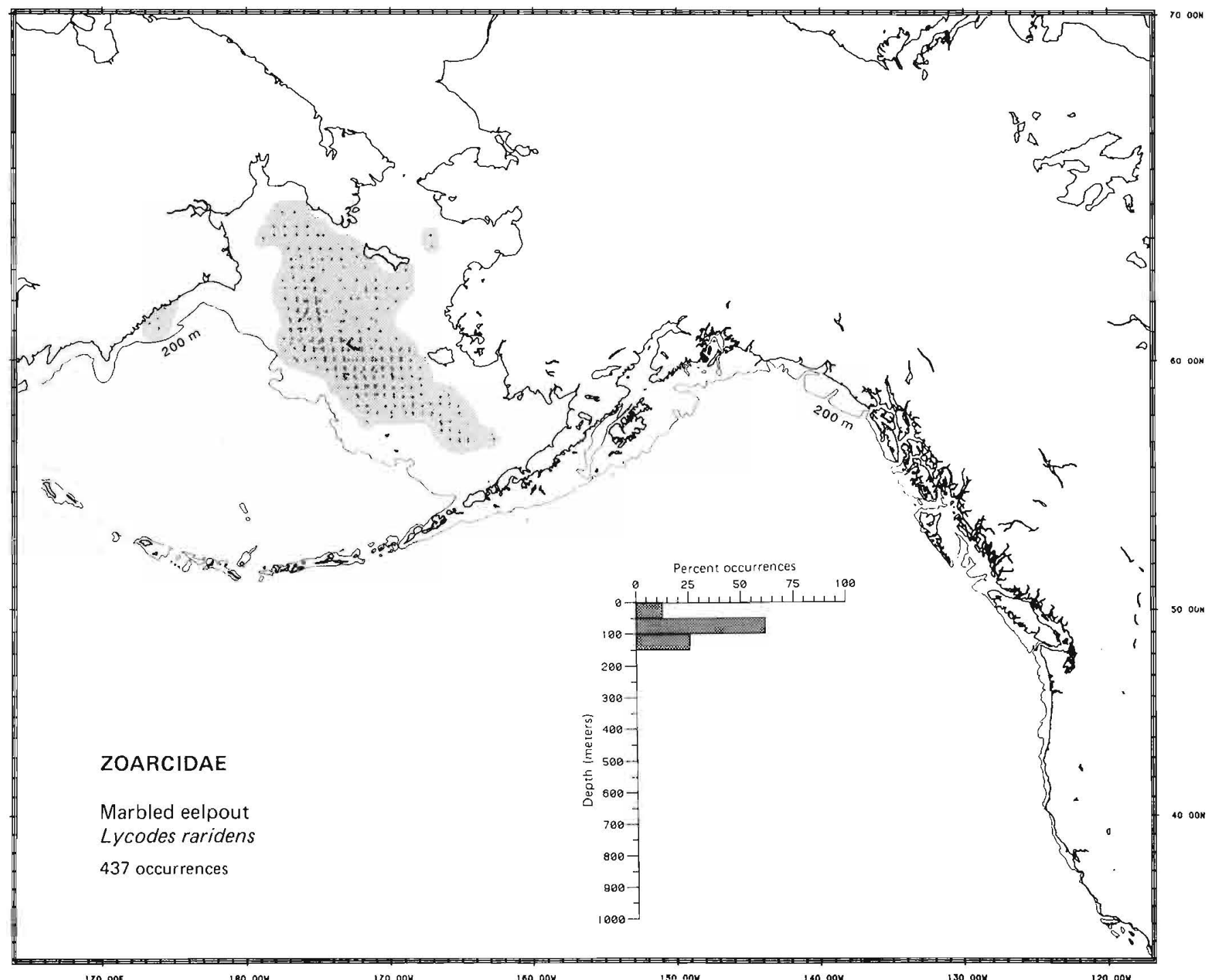


Literature Reported from the Anadyr Gulf and Norton Sound in the northern Bering Sea, north to the Alaskan Arctic and the Kara Sea, and in the North Atlantic from western Greenland and Hamilton Inlet, Labrador, south to the northern Gulf of Saint Lawrence (Andriyashev 1954; Leim and Scott 1966; Okada and Kobayashi 1968), from "shallow" to $64 \mathrm{~m}$ (Howe 1981).

Survey data Found from west of Cape Lisburne in the Chukchi Sea south in the eastern Bering Sea to west-central Bristol Bay. Depth range 25 to $125 \mathrm{~m}$, most frequently (57.3\% of occurrences) on the inner shelf at depths $<50 \mathrm{~m}$, and $92.8 \%$ of occurrences from depths $<100 \mathrm{~m}$. Survey data extend the known range south in the Bering Sea and expand the known depth range.

\section{Conclusions}

Zoogeography Arctic-western boreal Atlantic

Life zone Inner shelf-middle shelf (inner shelf)

Range From west-central Bristol Bay in the Bering Sea north to the Alaskan Arctic and the Kara Sea, and in the North Atlantic Depth 25 to $125 \mathrm{~m}$

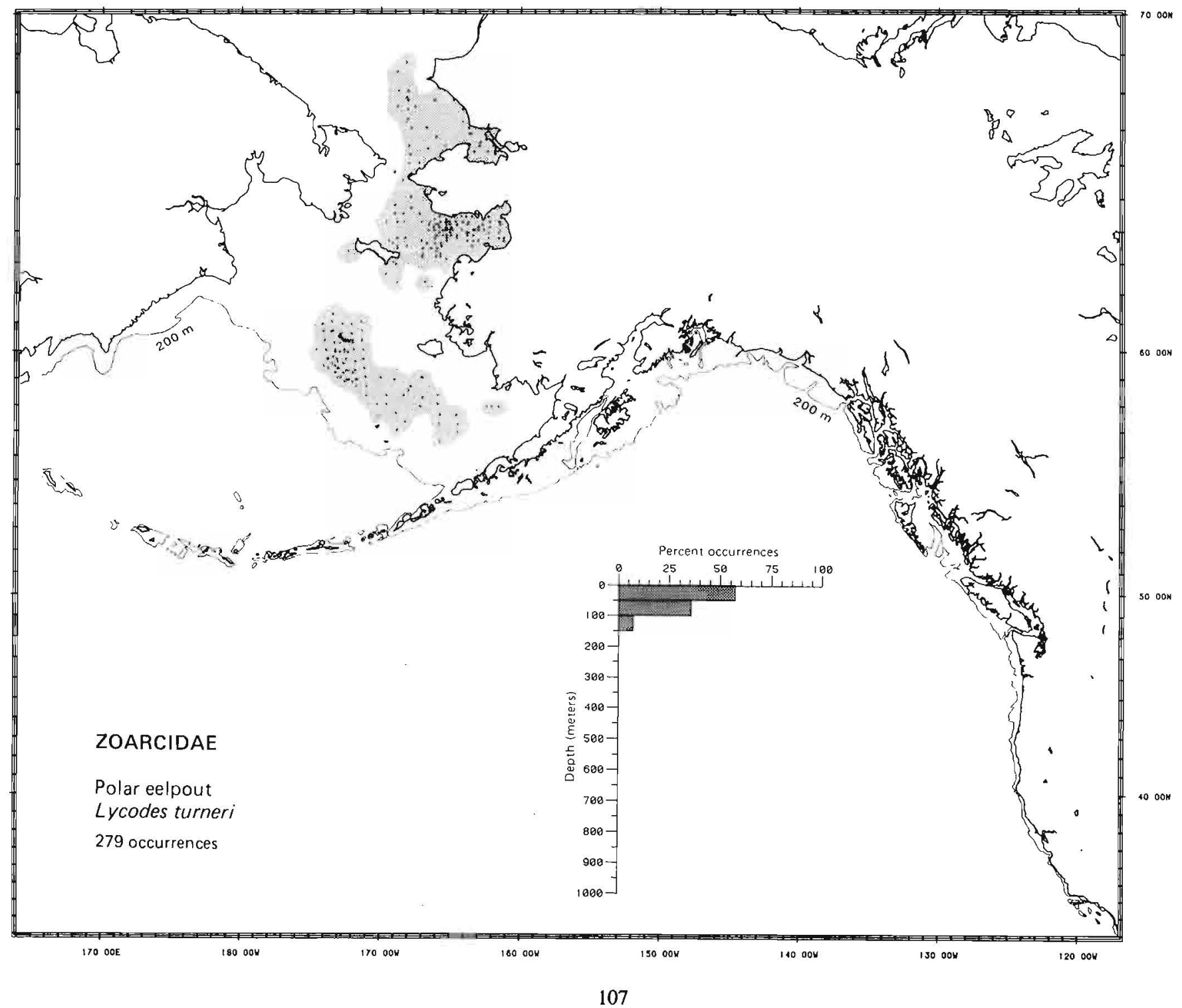


Literature Reported from the Sea of Okhotsk to the Bering Sea and southeast to Burrard Inlet, British Columbia (Quast and Hall 1972; Howe 1981; Eschmeyer and Herald 1983), at depths of 91 to $600 \mathrm{~m}$ (Fedorov 1973a; Eschmeyer and Herald 1983).

Survey data Found from Navarin Canyon on the northwest slope of the eastern Bering Sea and from east of Saint Matthew Island south to the slope north of Akutan Island, west in the Aleutian Islands to Tanaga Island, and east to Dixon Entrance in southeast Alaska. Depth range 25 to $825 \mathrm{~m}$, most frequently ( $51.6 \%$ of occurrences) on the outer shelf between 100 and $150 \mathrm{~m}$, and $94.9 \%$ of occurrences from depths $<400 \mathrm{~m}$. Survey data provide a more precise distribution of this species in the Bering Sea, extend its known range west in the Aleutian Islands, and expand its known depth range.

\section{Conclusions}

Zoogeography Northern boreal Pacific

Life zone Inner shelf-mesobenthal (outer shelf)

Range From the Sea of Okhotsk north to Navarin Canyon in the Bering Sea, west to Tanaga Island in the Aleutian Islands, Depth $\quad 25$ to $825 \mathrm{~m}$

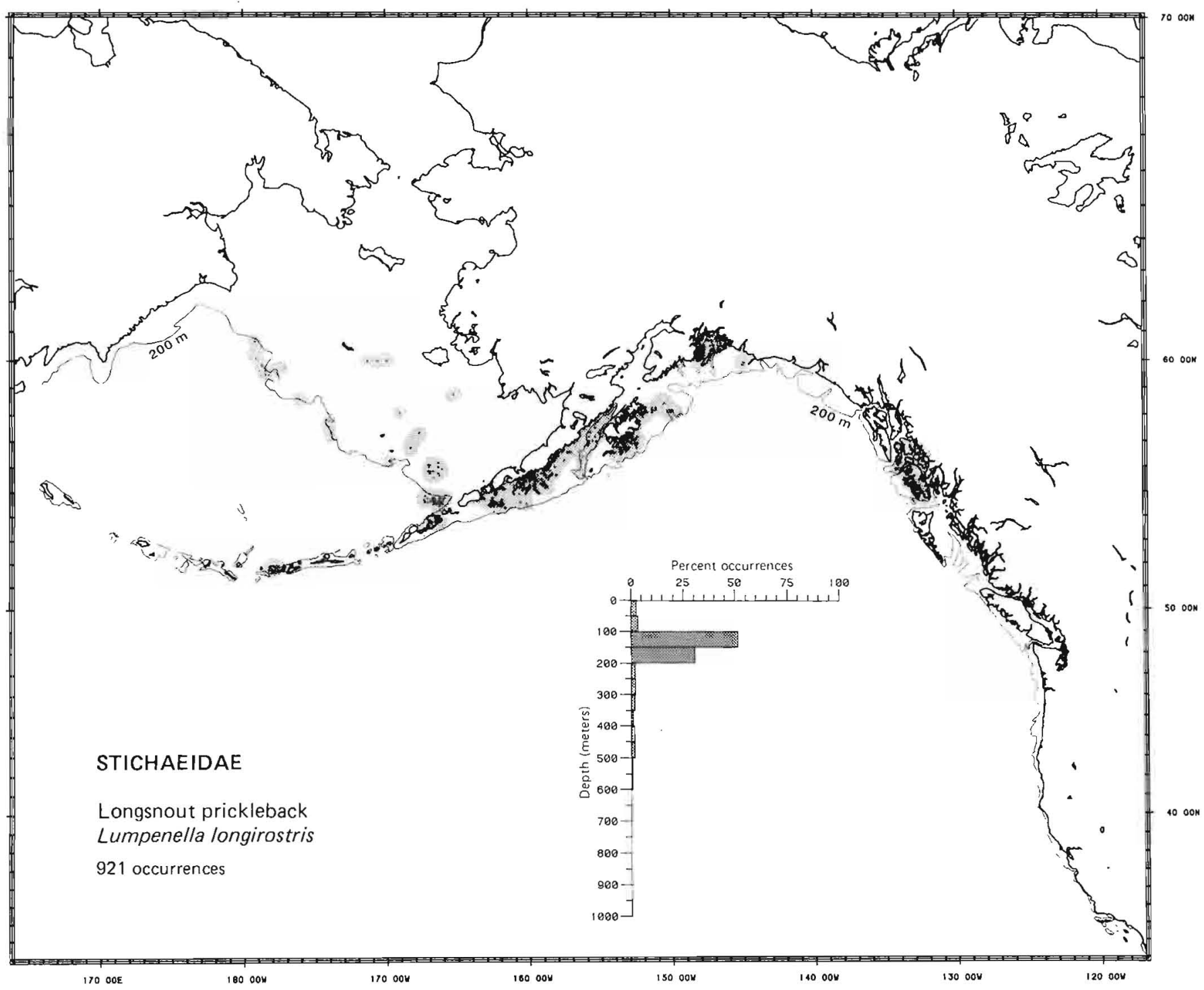


Literature Reported from the Sea of Japan and the Sea of Okhotsk and from southeastern Alaska north to the Arctic, and along the American coast of the Arctic to western Greenland and along the Asian coast to Novaya Zemlya (Andriyashev 1954; Quast and Hall 1972; Howe 1981), at depths from the intertidal zone to $119 \mathrm{~m}$ (Howe 1981).

Survey data Found from north of Cape Lisburne in the Chukchi Sea south to Navarin Canyon on the northwest slope of the eastern Bering Sea and Bristol Bay. Depth range 25 to $175 \mathrm{~m}$, most frequently $(81.7 \%$ of occurrences) on the inner shelf at depths $<50 \mathrm{~m}$, and $98.3 \%$ of occurrences from depths $<100 \mathrm{~m}$. Survey data provide a new maximum depth record.

\section{Conclusions}

Zoogeography Arctic-northern boreal Pacific

Life zone Inner shelf-outer shelf (inner shelf)

Range From the Sea of Japan and the Sea of Okhotsk and southeastern Alaska, north throughout the Arctic to western Greenland Depth Intertidal zone to $175 \mathrm{~m}$

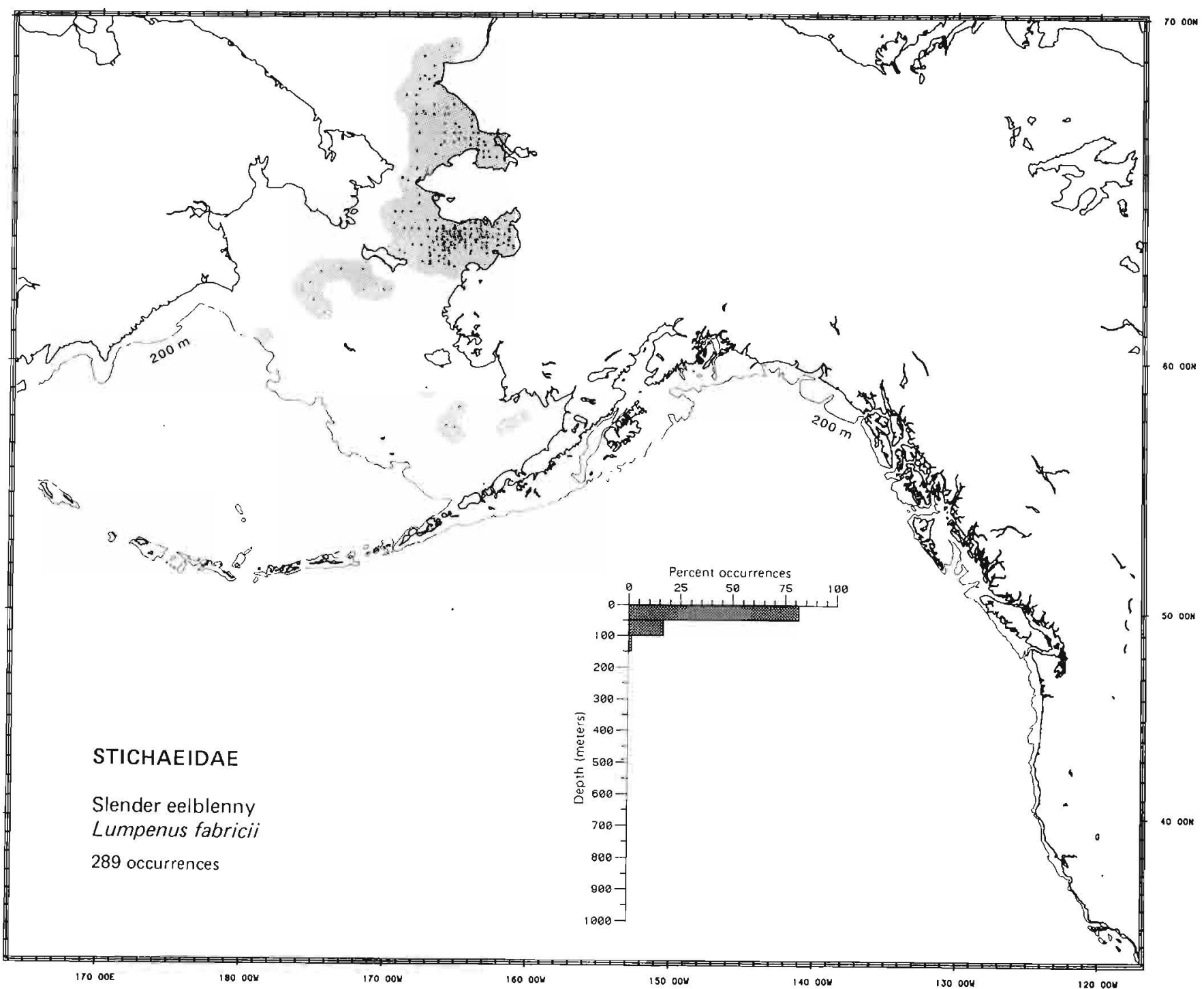


Taxonomic comment Makushok (1958), the most recent revision of the family Stichaeidae, considered the daubed shanny as Leptoclinus maculatus. Although J. S. Nelson (1984) recognized Leptoclinus, a monotypic genus, as valid, most workers currently examining the family regard Leptoclinus as a junior synonym of Lumpenus (E. M. Anderson, Dep. Ichthyol., Calif. Acad. Sci., San Francisco, CA 94118 , pers. commun. February 1986).

Literature Reported in the North Pacific from the northern Sea of Japan and Sea of Okhotsk in the west to Puget Sound, Washington, Unimak Island in the Aleutian Islands, and the Alaskan Arctic in the east, and in the North Atlantic from Cape Cod, Massachusetts, north to southern Baffin Island and Greenland, Iceland, Spitsbergen, the Barents Sea, and south to the Skagerrak (Andriyashev 1954; Wilimovsky 1964; Leim and Scott 1966; Hart 1973; Wheeler 1978; Eschmeyer and Herald 1983), at depths of 15 to $400 \mathrm{~m}$ (Andriyashev 1954).

Survey data Found from southwest of Providence Bay on the Anadyr Gulf southeast to Bristol Bay and Unalaska Island, and east to Yakutat Bay in the Gulf of Alaska. Depth range 25 to $175 \mathrm{~m}$, most frequently (55.0\% of occurrences) on the middle shelf between 50 and $100 \mathrm{~m}$, and $99.6 \%$ of occurrences from depths $<150 \mathrm{~m}$. Survey data extend the known range slightly west in the Aleutian Islands to Unalaska Island.

\section{Conclusions}

Zoogeography Arctic-amphiboreal (circumboreal Atlantic-northern boreal Pacific)

Life zone Inner shelf-outer shelf (middle shelf)

Range From the northern Sea of Japan and Sea of Okhotsk, Unalaska Island, and Puget Sound, Washington, north to the Alaskan Arctic, and in the North Atlantic from Cape Cod, Massachusetts, north to Spitsbergen, the Barents Sea, and south to the Skagerrak

Depth $\quad 15$ to $400 \mathrm{~m}$

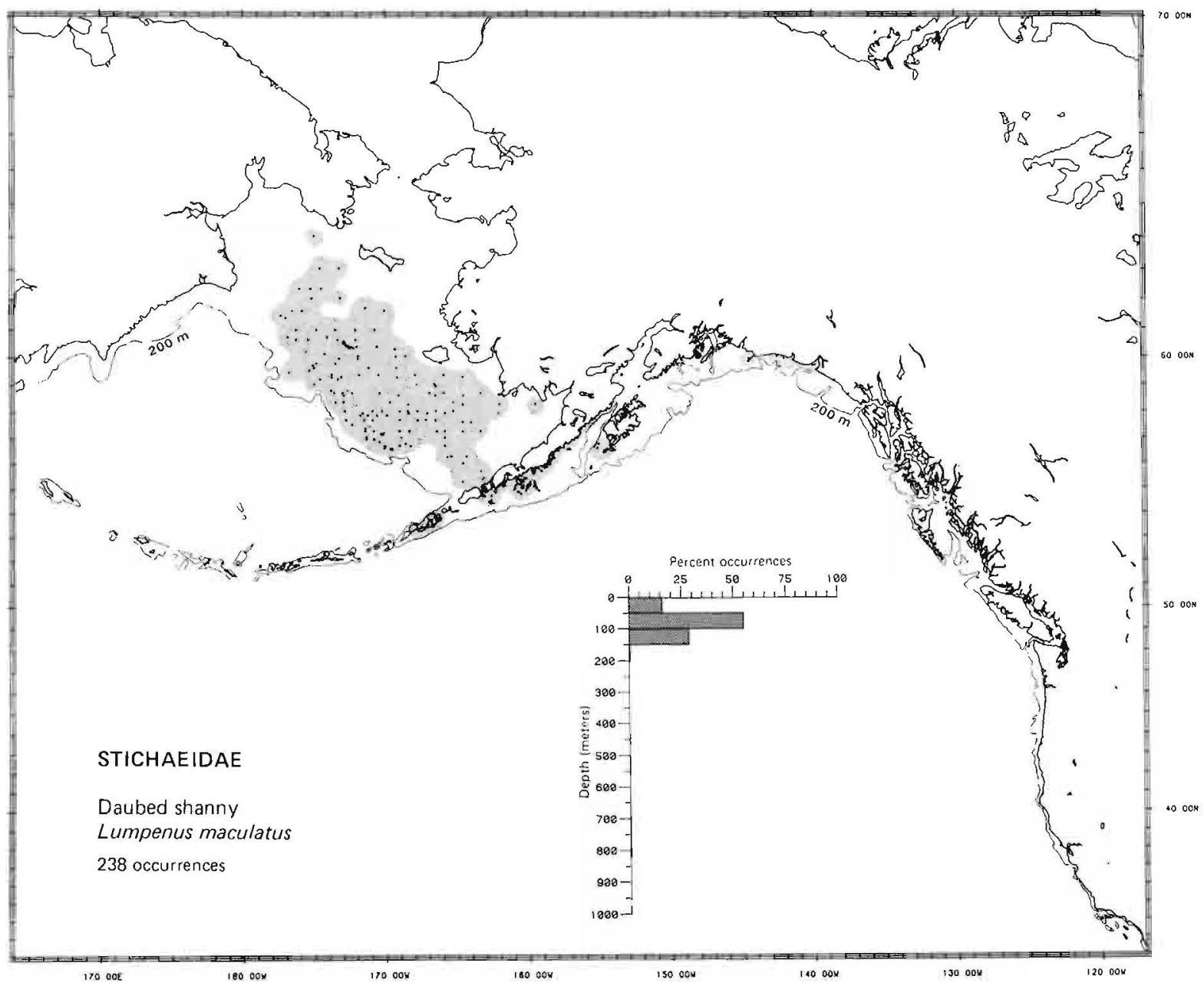


Literature Reported from the Sea of Japan and Sakhalin to the Bering Sea, west along the Aleutian Islands to Adak Island and southeast to San Francisco, California (Wilimovksy 1964; Okada and Kobayashi 1968; Quast and Hall 1972; Eschmeyer and Herald 1983), from "shallow depths" to $207 \mathrm{~m}$ (Eschmeyer and Herald 1983).

Survey data Found from Saint Lawrence Island in the Bering Sea southeast along the shelf to Unalaska Island, and east to Wrangell, Alaska. Depth range 25 to $425 \mathrm{~m}$, most frequently (42.9\% of occurrences) on the middle shelf between 50 and $100 \mathrm{~m}$, and $98.8 \%$ of occurrences from depths $\leqslant 200 \mathrm{~m}$. Survey data provide a more precise distribution of this species in the Bering Sea and expand its known depth range.

\section{Conclusions}

Zoogeography Kurile-Aleutian

Life zone Inner shelf-outer shelf (middle shelf)

Range From the Sea of Japan and Sakhalin to Saint Lawrence Island in the Bering Sea, west to Adak Island in the Aleutian Islands, and south to San Francisco, California

Depth 25 to $425 \mathrm{~m}$

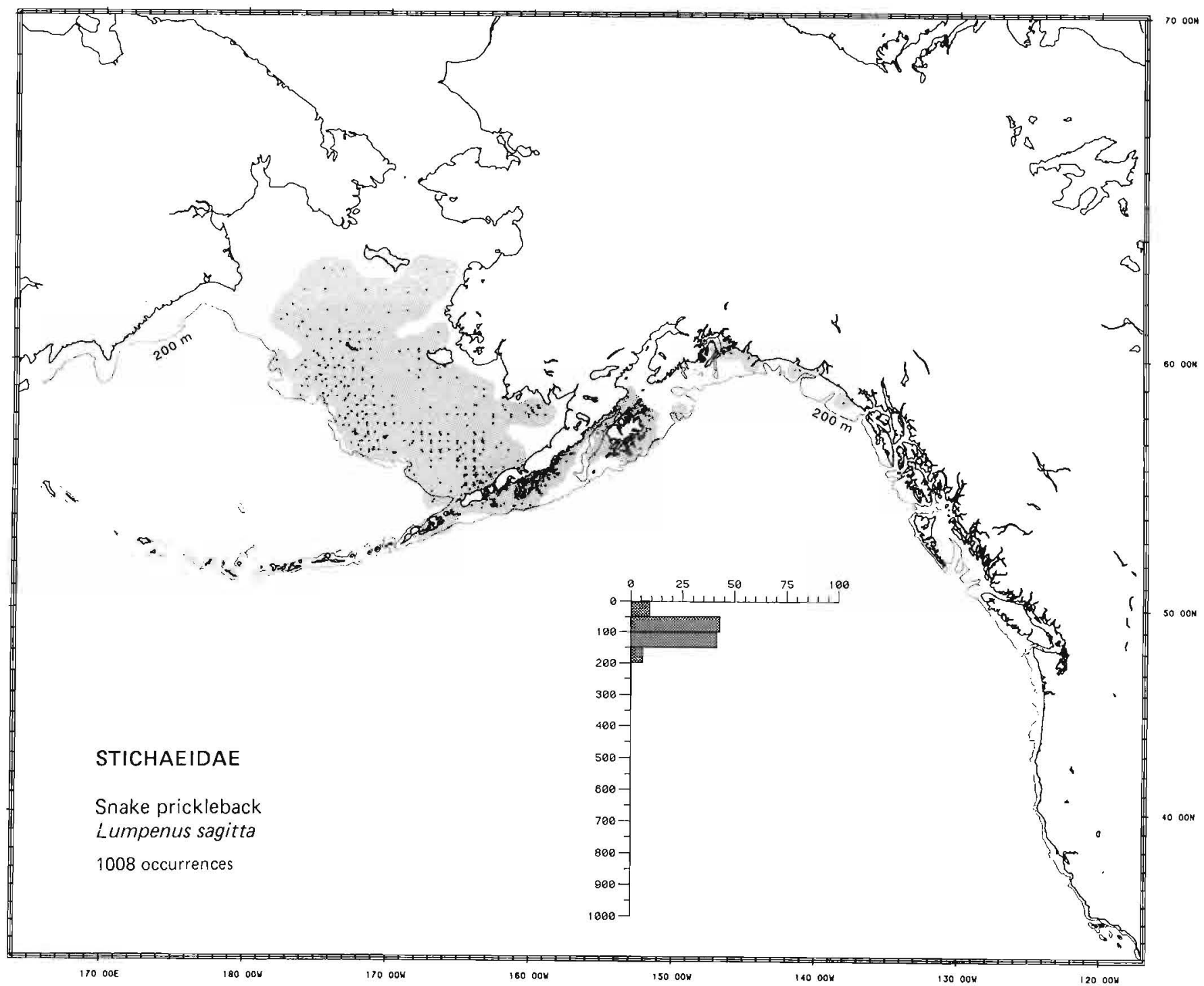


Literature Reported from Hokkaido, Japan, and western Kamchatka to the Bering Sea, west along the Aleutian Islands to Attu Island, and southeast to Monterey Bay, California (Hart 1973; Howe 1981; Eschmeyer and Herald 1983), at depths of 10 to $550 \mathrm{~m}$ (Shmidt 1950 ; Fedorov 1973a; Howe 1981).

Survey data Found from Navarin Canyon on the northwestern slope of the eastern Bering Sea southeast to Unimak Island and Port Moller (on the Alaska Peninsula), west in the Aleutian Islands to Stalemate Bank, and southeast to San Miguel Island in southern California. Depth range 25 to $675 \mathrm{~m}$, most frequently (24.4\% of occurrences) on the outer shelf between 100 and $150 \mathrm{~m}$, and $97.0 \%$ of occurrences from depths $\leqslant 350 \mathrm{~m}$. Survey data provide a more precise distribution of this species in the Bering Sea, extend its known range south to San Miguel Island, California, and provide a new maximum depth record.

\section{Conclusions}

Zoogeography Northeastern boreal Pacific

Life zone Inner shelf-mesobenthal (outer shelf)

Range From Hokkaido, Japan, and western Kamchatka to Navarin Canyon in the Bering Sea, west in the Aleutian Islands to Artu Island, and southeast to San Miguel Island, California

Depth 10 to $675 \mathrm{~m}$

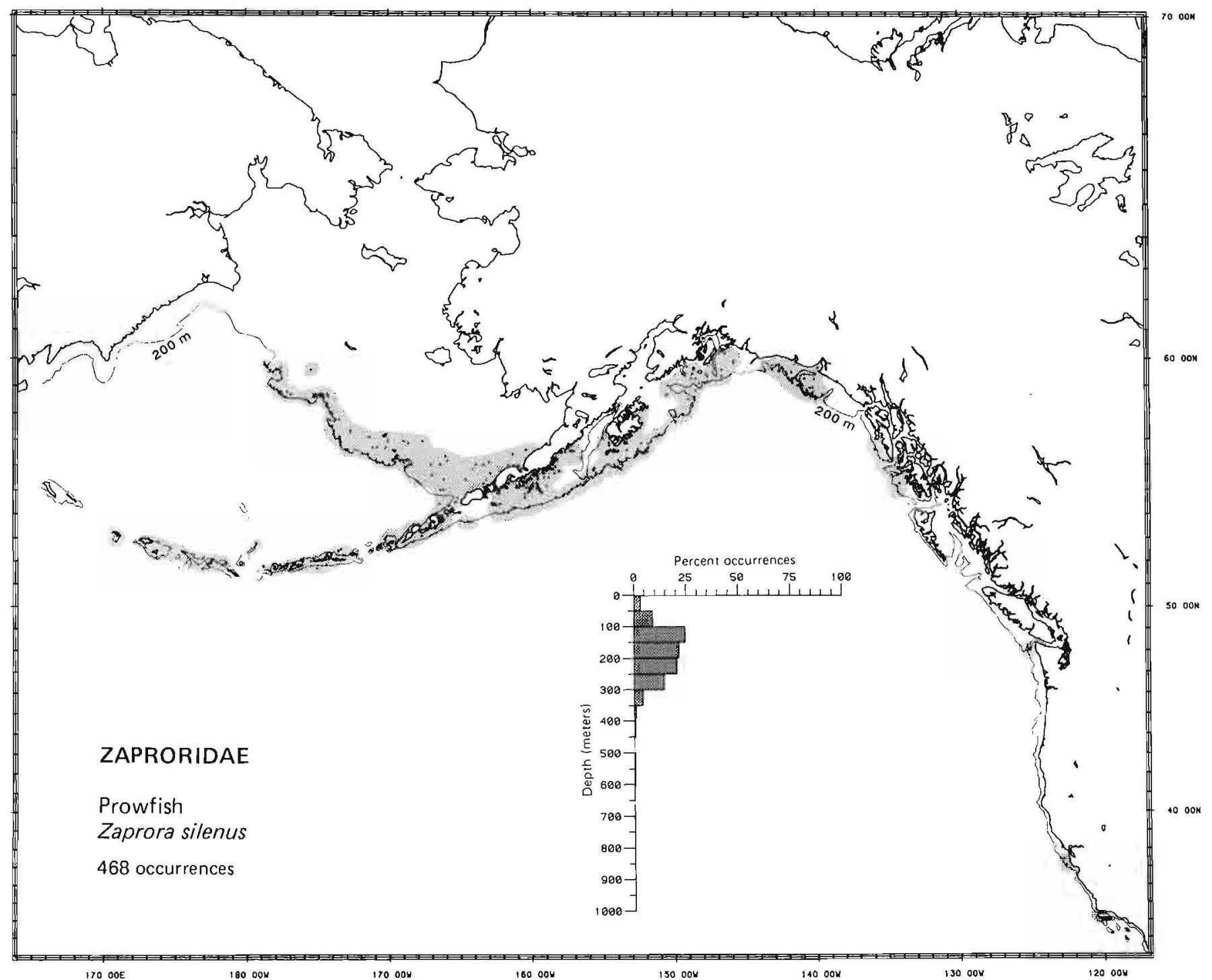


Literature Reported from the southeastern Bering Sea, west in the Commander-Aleutian Islands to Medny Island and southeast to San Francisco, California (Wilimovsky 1964; Hart 1973; Eschmeyer and Herald 1983), from "inshore regions" to $250 \mathrm{~m}$ (Fedorov 1973a; Eschmeyer and Herald 1983).

Survey data Found from offshore of Nunivak Island and Saint Paul Island in the southeastern Bering Sea east throughout Bristol Bay, west in the Aleutian Islands to Unalaska Island, and east to Cape Fairweather in southeast Alaska. Depth range 25 to $375 \mathrm{~m}$, most frequently (43.8\% of occurrences) on the middle shelf between 50 and $100 \mathrm{~m}$, and $95.0 \%$ of occurrences from depths $<150 \mathrm{~m}$. Survey data provide a more precise range of this species in the Bering Sea and expand its known depth distribution.

\section{Conclusions}

Zoogeography Eastern boreal Pacific

Life zone Inner shelf-outer shelf (middle shelf)

Range From Nunivak Island in the Bering Sea, west in the Commander-Aleutian Islands to Medny Island, and southeast to San Francisco, California

Depth 20 to $375 \mathrm{~m}$

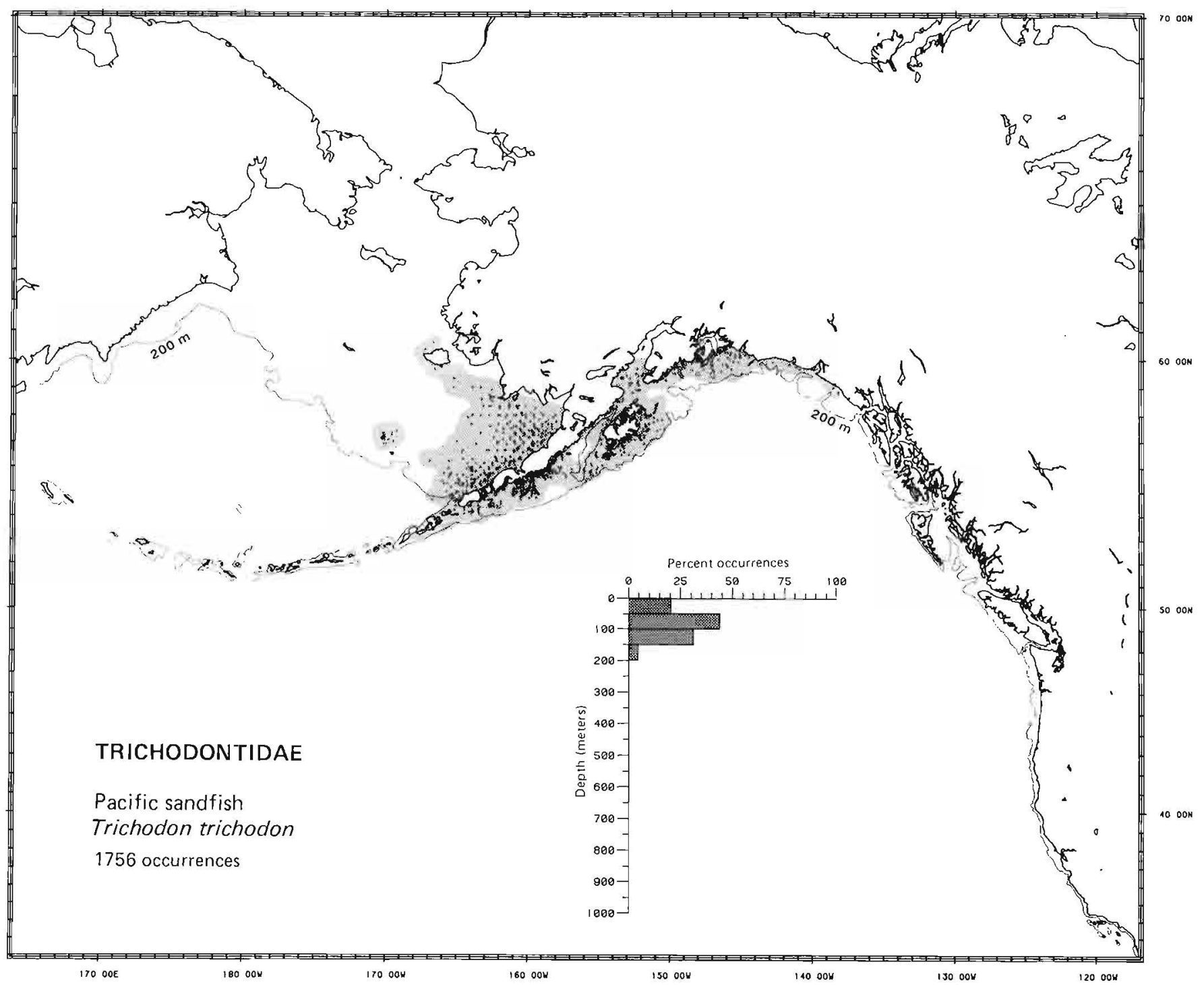


Literature Reported from the northern Sea of Japan and the Sea of Okhotsk north to the Canadian Arctic, throughout the Bering Sea, west in the Aleutian Islands to Attu Island, and south to Balboa Island in southern California (Wilimovsky 1964; Hart 1973; Eschmeyer and Herald 1983), at depths from the intertidal zone to $100 \mathrm{~m}$ (Fedorov 1973a; Eschmeyer and Herald 1983).

Survey data Found from offshore of Cape Nizkiy (on the Korak Coast of the western Bering Sea) north to Cape Lisburne in the Chukchi Sea, southeast in the Bering Sea to Bristol Bay and Unimak Island, west in the Aleutian Islands to Attu Island, and east to the north end of Graham Island, British Columbia. Depth range 25 to $275 \mathrm{~m}$, most frequently ( $73.3 \%$ of occurrences) on the inner shelf at depths $<50 \mathrm{~m}$, and $97.8 \%$ of occurrences from depths $<100 \mathrm{~m}$. Survey data provide a new maximum depth record; however, because this species can occur pelagically, it may have been taken near the surface but recorded at a greater depth.

\section{Conclusions}

Zoogeography Arctic-northeastern Pacific

Life zone Inner shelf-middle shelf (inner shelf)

Range From the northern Sea of Japan and Sea of Okhotsk, Attu Island in the Aleutian Islands, and Balboa Island, California, north to the Canadian Arctic

Depth Intertidal zone to $100 \mathrm{~m}$, possibly to $275 \mathrm{~m}$

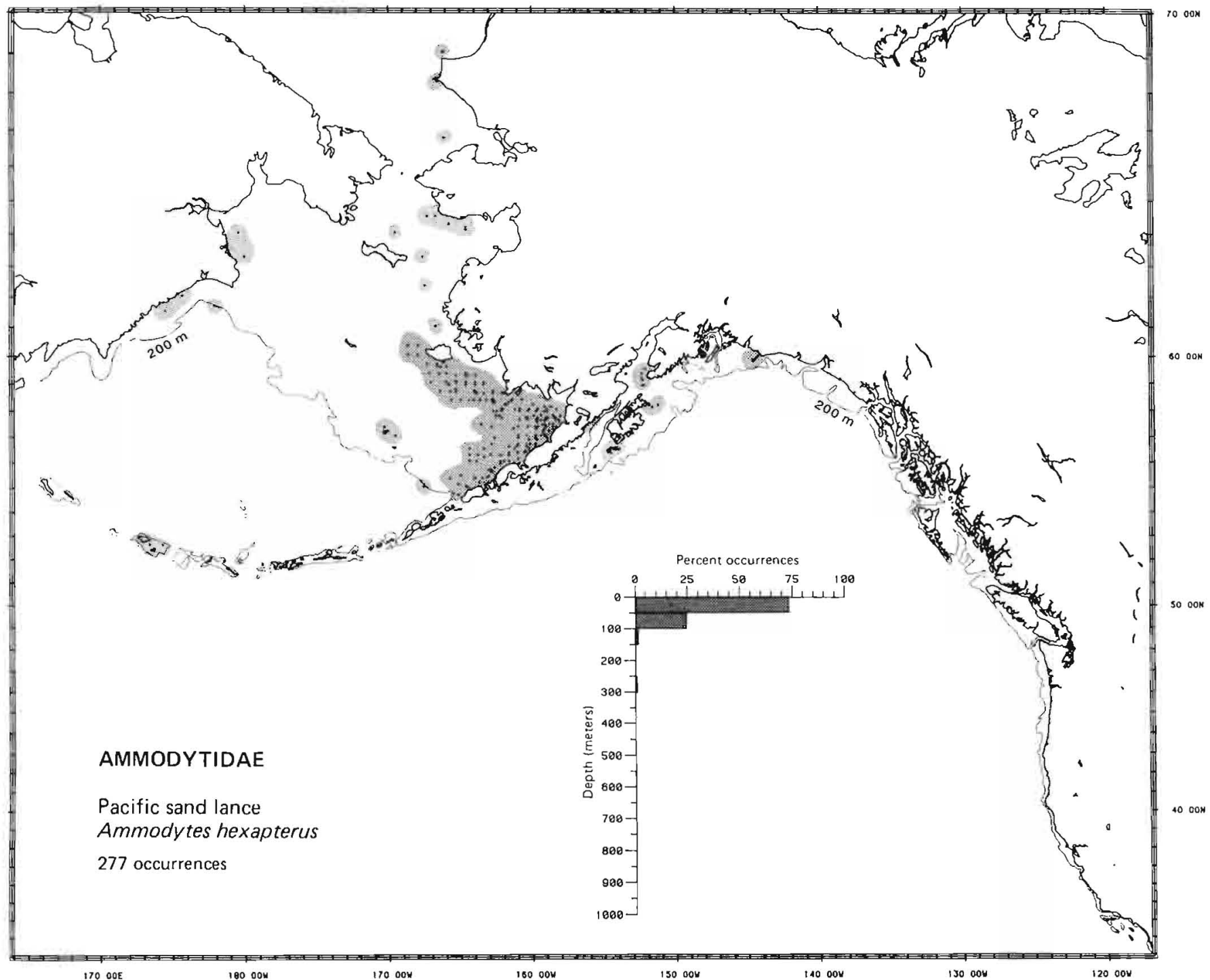


Literature Reported from Kiska Island in the Aleutian Islands and the Bering Sea to Cape San Lucas, Baja California Sur (Wilimovsky 1964; Miller and Lea 1972), at depths of 0 to $549 \mathrm{~m}$ (Howe 1981; Eschmeyer and Herald 1983).

Survey data Found from Cape Edgecumbe in southeast Alaska to Los Angeles, California, with one anomalous record from the southeastern Bering Sea. Depth range 25 to $425 \mathrm{~m}$, most commonly (46.9\% of occurrences) on the middle shelf between 50 and $100 \mathrm{~m}$, and $93.7 \%$ of occurrences from depths $\leqslant 150 \mathrm{~m}$. Survey data were all within the known geographic range and known depth range.

\section{Conclusions}

Zoogeography Oregonian-San Diegan

Life zone Inner shelf-outer shelf (middle shelf)

Range From Kiska Island in the Aleutian Islands and the southeastern Bering Sea to Cape San Lucas, Baja California Sur Depth $\quad 0$ to $549 \mathrm{~m}$

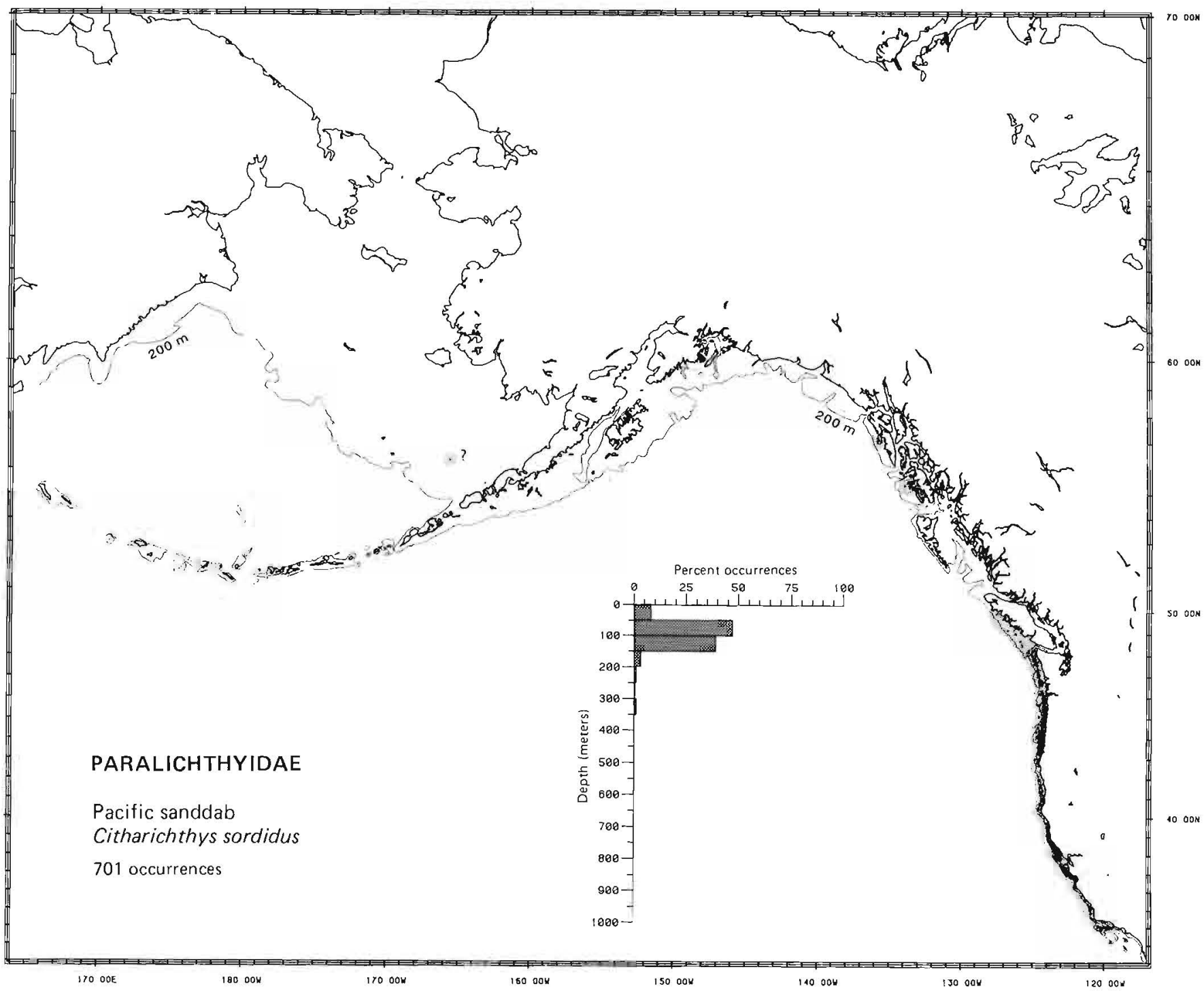




\section{Jordan and Starks 1904}

Literature Reported from the Sea of Japan and Sea of Okhotsk north to the Anadyr Gulf, southeast in the Bering Sea to the Alaska Peninsula, west throughout the Aleutian Islands, and east to Shelikof Strait in the Gulf of Alaska (Shuntov 1965; Quast and Hall 1972; Hart 1973), at depths of 33 to $1100 \mathrm{~m}$ (Fedorov 1973a).

Survey data Found from northeast of Cape Olyutorski north to Cape Navarin in the western Bering Sea, south along the outer shelf of the eastern Bering Sea to Unimak Pass, west along the Aleutian Islands to Atka Island, and east to south Shelikof Strait in the northwestern Gulf of Alaska. Depth range 25 to $675 \mathrm{~m}$ in depth, most frequently (26.5\% of occurrences) on the outer shelf from 100 to $150 \mathrm{~m}$, and $95.3 \%$ of occurrences from 50 to $500 \mathrm{~m}$. Survey data provide a slightly shallower minimum depth record. Over much of the eastern range of Kamchatka flounder, the species may have been misidentified as arrowtooth flounder, Atheresthes stomias (Ranck et al. 1986).

\section{Conclusions}

Zoogeography Northern boreal Pacific

Life zone Middle shelf-mesobenthal (outer shelf)

Range From the Sea of Japan and Sea of Okhotsk north to the Anadyr Gulf, through the eastern Bering Sea to Unimak Pass, west in the Aleutian Islands to Atka Island, and east to Shelikof Strait in the northwestern Gulf of Alaska

Depth 25 to $1100 \mathrm{~m}$

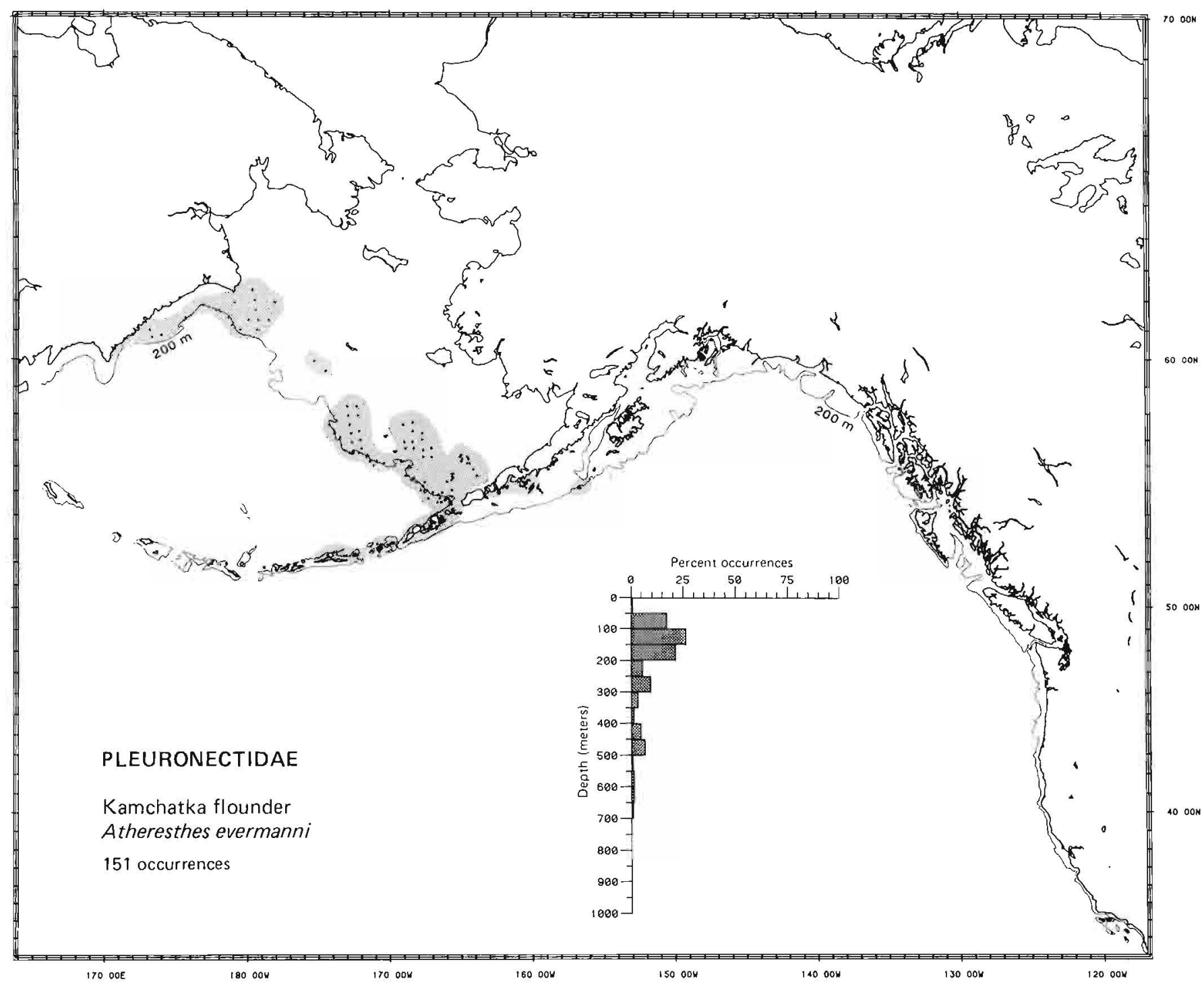



(Jordan and Gilbert 1880)

Literature Reported from the Bering Sea (and questionably, the Chukchi Sea) and Attu Island in the Aleutian Islands to San Pedro, California, from 18 to $900 \mathrm{~m}$ in depth (Wilimovsky 1964; Miller and Lea 1972; Webber and Sample 1976; Eschmeyer and Herald 1983).

Survey data Found from off Glubokaya Bay (northeast of Cape Olyutorski) in the western Bering Sea north to southwest of Saint Lawrence Island, south along the outer shelf of the eastern Bering Sea, west along the Aleutian Islands to Bowers Bank and Stalemate Bank, and from there southeast to San Simeon, California. One record from west of Point Hope in the Chukchi Sea was probably a misidentification. Found at depths of 25 to $875 \mathrm{~m}$, most frequently (33.5\% of occurrences) on the outer shelf between 100 to $150 \mathrm{~m}$, and $95.2 \%$ of occurrences from depths $\leqslant 400 \mathrm{~m}$. Survey data define the northern and western limits in the Bering Sea. However, the Kamchatka flounder, Atheresthes evermanni, may have been confused with this species in some regions such as the northern Bering Sea and Aleutian Islands (Ranck et al. 1986). The San Pedro, California, record for this species given in Miller and Lea (1972) is a mistakenly identified slender sole, Eopsetta exilis.

\section{Conclusions}

Zoogeography Eastern boreal Pacific

Life zone Inner shelf-mesobenthal (outer shelf)

Range From off Glubokaya Bay in the western Bering Sea and Stalemate Bank in the Aleutian Islands to San Simeon, California Depth 18 to $900 \mathrm{~m}$

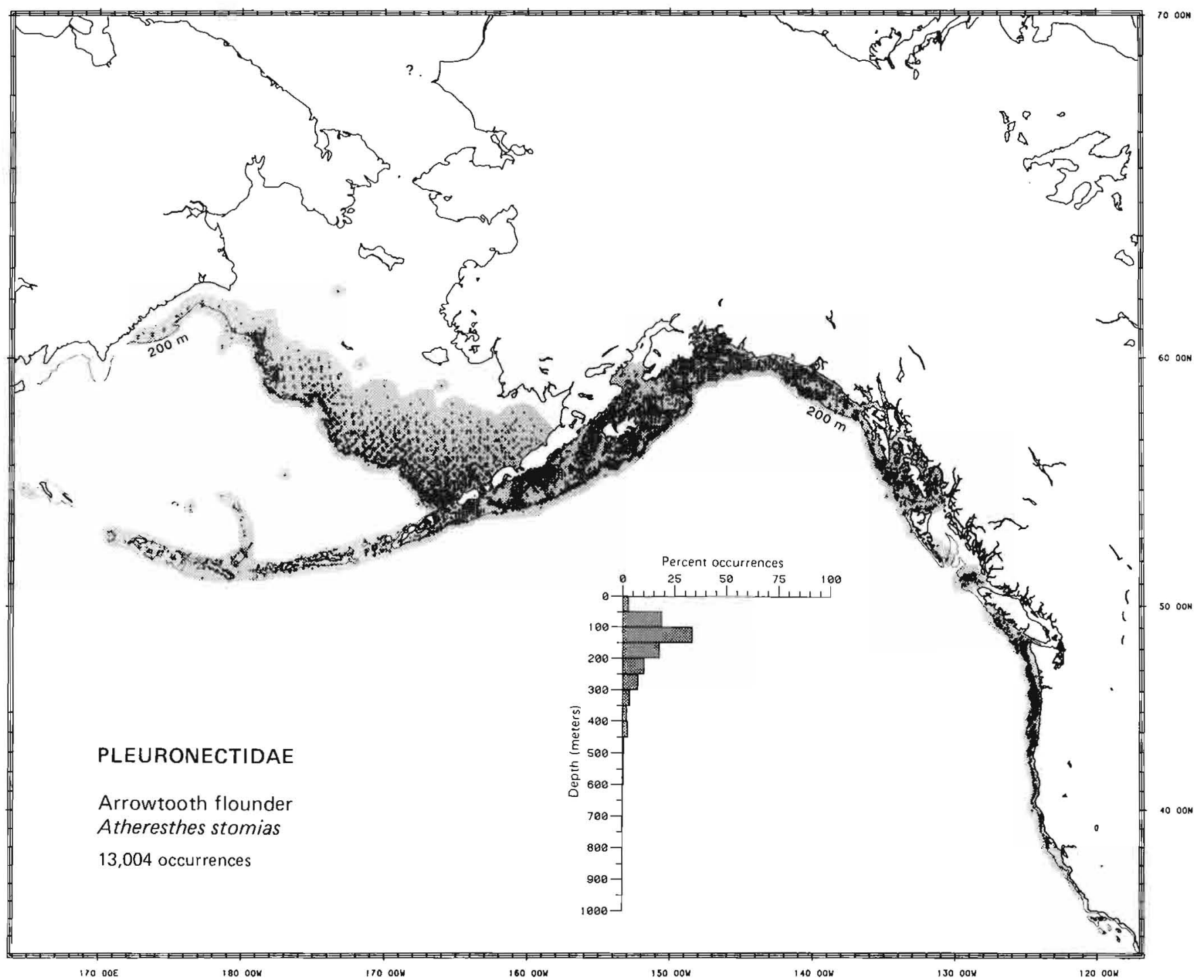


Taxonomic comment The slender sole is Lyopsetta exilis in Robins (1980), but Sakamoto (1984), the most recent revision of the family Pleuronectidae, placed the species in the genus Eopsetta.

Literature Reported from Alsek Canyon off southeastern Alaska to Cedros Island, Baja California (Miller and Lea 1972), and from 50 to $800 \mathrm{~m}$ in depth (Howe 1981; Allen 1982).

Survey data Found from North Albatross Bank (east of Kodiak Island) to Oxnard, California; one record from north of Akutan Island in the Bering Sea is anomalous. Depth range from 25 to $475 \mathrm{~m}$, found most frequently (35.6\% of occurrences) on the outer shelf between 100 and $150 \mathrm{~m}$, and $98.1 \%$ of occurrences were from 50 to $350 \mathrm{~m}$. Survey data extend the western range limit to North Albatross Bank and provide a new minimum known depth.

\section{Conclusions}

Zoogeography Eastern boreal Pacific

Life zone Middle shelf-mesobenthal (outer shelf)

Range From North Albatross Bank, Alaska, to Cedros Island, Baja California

Depth 25 to $800 \mathrm{~m}$

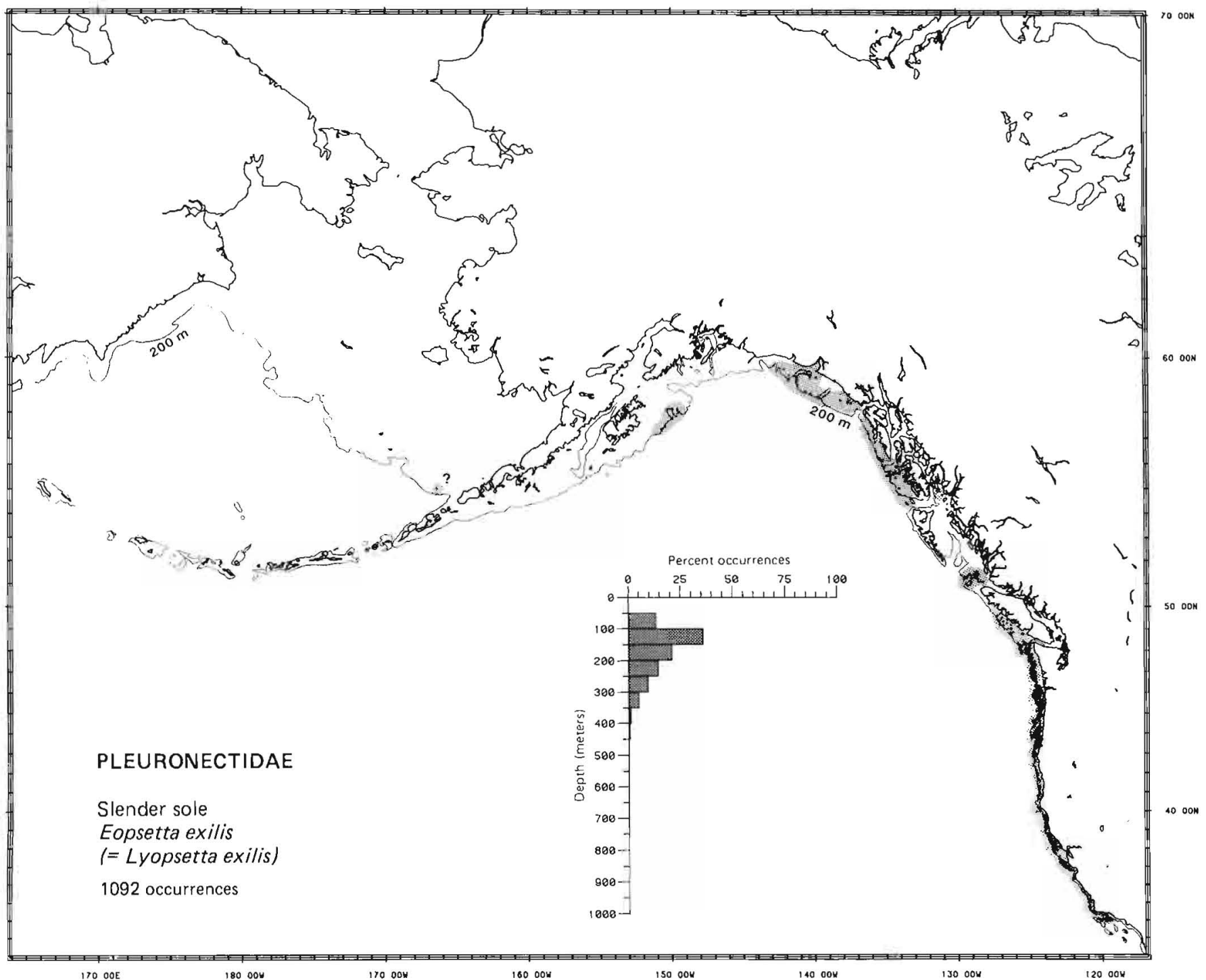


Literature Reported from the Bering Sea to the Coronado Islands, Baja California (Miller and Lea 1972; Eschmeyer and Herald 1983), ranging in depth from 0 to $550 \mathrm{~m}$ (Hart 1973).

Survey data Found from Kupreanof Point on the Alaska Peninsula to Oxnard, California. Depth range 25 to $475 \mathrm{~m}$, most frequently (33.9\% of occurrences) on the outer shelf between 100 and $150 \mathrm{~m}$, and $96.2 \%$ of occurrences from depths $\leqslant 300 \mathrm{~m}$. Survey data were all within the known geographic range and known depth range.

\section{Conclusions}

Zoogeography Eastern boreal Pacific

Life zone Inner shelf-mesobenthal (outer shelf)

Range From the Bering Sea to the Coronado Islands, Baja California

Depth 0 to $550 \mathrm{~m}$

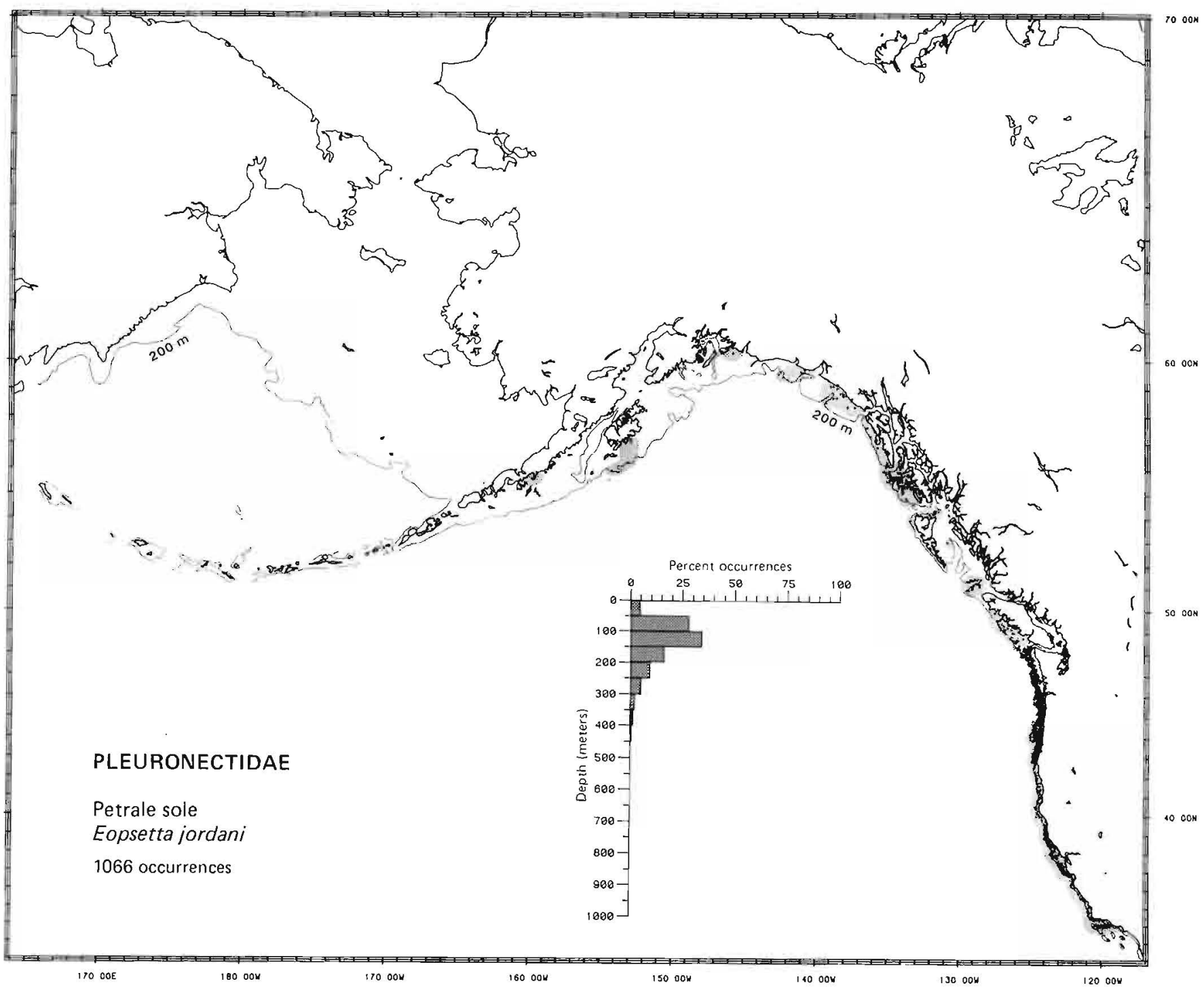


Taxonomic comment The rex sole is Glyptocephalus zachirus in Robins (1980), but Sakamoto (1984), the most recent revision of the family Pleuronectidae, places the species in the genus Errex.

Literature Reported from the eastern Bering Sea and Amchitka Island in the Aleutian Islands to Cedros Island, Baja California (Miller and Lea 1972; Hart 1973; Simenstad et al. 1977), and at depths of 0 to $850 \mathrm{~m}$ (Hart 1973; Fedorov 1973a).

Survey data Found off Glubokaya Bay in the western Bering Sea and along the outer shelf of the eastern Bering Sea from Navarin Canyon in the north to eastern Bristol Bay, in the Aleutian Islands from Stalemate Bank and Bowers Bank, through the Gulf of Alaska to Santa Barbara, California. Depth range 25 to $525 \mathrm{~m}$, most commonly ( $31.6 \%$ of occurrences) on the outer shelf between 100 and $150 \mathrm{~m}$, and $95.9 \%$ of occurrences from depths of 50 to $450 \mathrm{~m}$. Survey data extend the known range to the western Bering Sea and Aleutian Islands, and provide a more detailed distribution in the eastern Bering Sea.

\section{Conclusions}

Zoogeography Eastern boreal Pacific

Life zone Middle shelf-mesobenthal (outer shelf)

Range From off Glubokaya Bay in the western Bering Sea and Stalemate Bank in the Aleutian Islands to Cedros Island, Baja California

Depth 0 to $850 \mathrm{~m}$

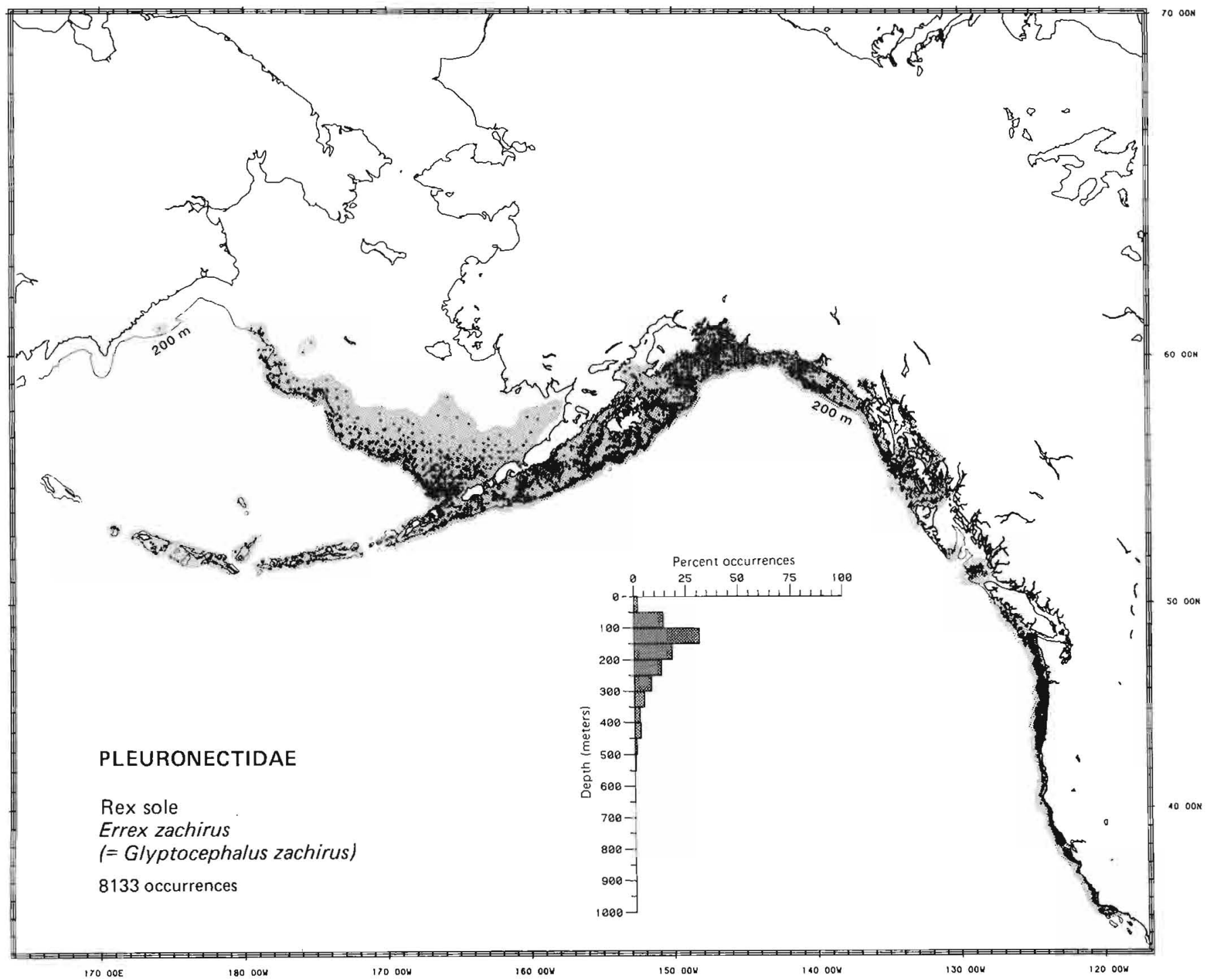


Literature Reported from the northern Kurile Islands and western Kamchatka to the Korak Coast of the western Bering Sea, from there south to the Alaska Peninsula, west in the Aleutian Islands to Amchitka Island, and southeast to Point Reyes, California (Simenstad et al. 1977; Fadeev 1978). Reports of this species in the Chukchi Sea (Quast and Hall 1972) are probably of the Bering flounder, Hippoglossoides robustus, rather than of the flathead sole (Fadeev 1978). Reports of this species from the Sea of Japan (Quast and Hall 1972) are probably of the red flounder, Hippoglossoides dubius Schmidt 1904, which is regarded as a species rather than as a subspecies of the flathead sole by Fadeev (1978) and Sakamoto (1984). Reported from 0 to $1050 \mathrm{~m}$ (Hart 1973; Fedorov 1973a).

Survey data Found from Cape Olyutorski in the western Bering Sea, north to the Anadyr Gulf and Saint Lawrence Island, and south throughout the middle and outer shelf of the eastern Bering Sea; in the Aleutian Islands, as far west as Stalemate and Bowers Banks and west of Bering Island in the Commander Islands; from the Aleutians, southeast to Monterey, California. Depth range 25 to $875 \mathrm{~m}$, most frequently (37.1\% of occurrences) on the outer shelf between 100 and $150 \mathrm{~m}$, and $93.3 \%$ of occurrences from depths <250 m. Survey data extend the southern and Aleutian Island limits.

\section{Conclusions \\ Zoogeography Kurile-Aleutian \\ Life zone Inner shelf-mesobenthal (outer shelf) \\ Range From the northern Kurile Islands to the Anadyr Gulf, southeast in the Bering Sea, west in the Aleutian Islands to Stalemate Bank, and southeast to Monterey, California \\ Depth 0 to $1050 \mathrm{~m}$}

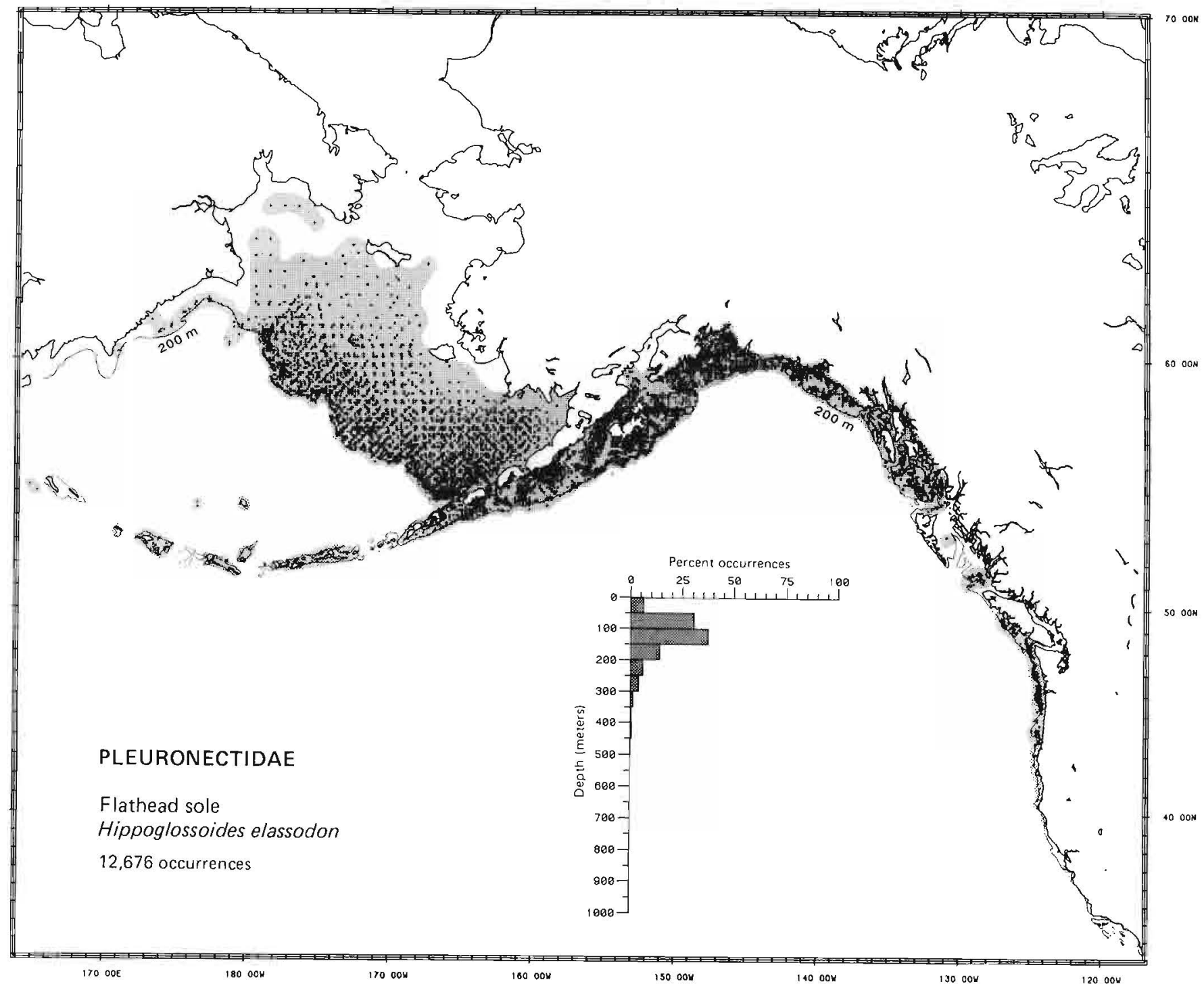


Taxonomic comment Fadeev (1978) considered the Bering flounder to be a subspecies of the flathead sole, Hippoglossoides elassodon. However, F. M. Utter (Northwest and Alaska Fish. Cent., Natl. Mar. Fish. Serv., NOAA, Seattle, WA 98112, pers. commun. February 1986), based on genetic evidence from Bering Sea populations, and Sakamoto (1984) considered the Bering flounder to be a valid species.

Literature Reported from Hokkaido, Japan, the Tatar Strait, and the Sea of Okhotsk to the Aleutian Islands, Chukchi Sea, and southeastern Bering Sea (Andriyashev 1954; Quast and Hall 1972; Hart 1973; Howe 1981), and in depth from 18 to $293 \mathrm{~m}$ (Fedorov 1973a).

Survey data Found from Cape Olyutorski in the western Bering Sea north to northeast of Cape Lisburne in the Chukchi Sea and south along the middle shelf of the eastern Bering Sea to northwest of Akutan Island. One anomalous record was reported from Little Sitkin Island in the Aleutian Islands. Depth range 25 to $425 \mathrm{~m}$, most frequently (58.5\% of occurrences) on the middle shelf between 50 and $100 \mathrm{~m}$, and $96.8 \%$ of occurrences from depths $\leqslant 150 \mathrm{~m}$. Survey data were all within the known geographic range, but give a more precise distribution in the north and east, and extend the known depth range into deeper water. The flathead sole, Hippoglossoides elassodon, may have been confused with this species in the southeastern Bering Sea.

\section{Conclusions}

\section{Zoogeography Arctic-Okhotsk}

Life zone Inner shelf-outer shelf (middle shelf)

Range From Hokkaido, Japan, and the Sea of Okhotsk north to northeast of Cape Lisburne, south in the Bering Sea to northwest of Akutan Island, and possibly west to Little Sitkin Island in the Aleutians

Depth 18 to $425 \mathrm{~m}$

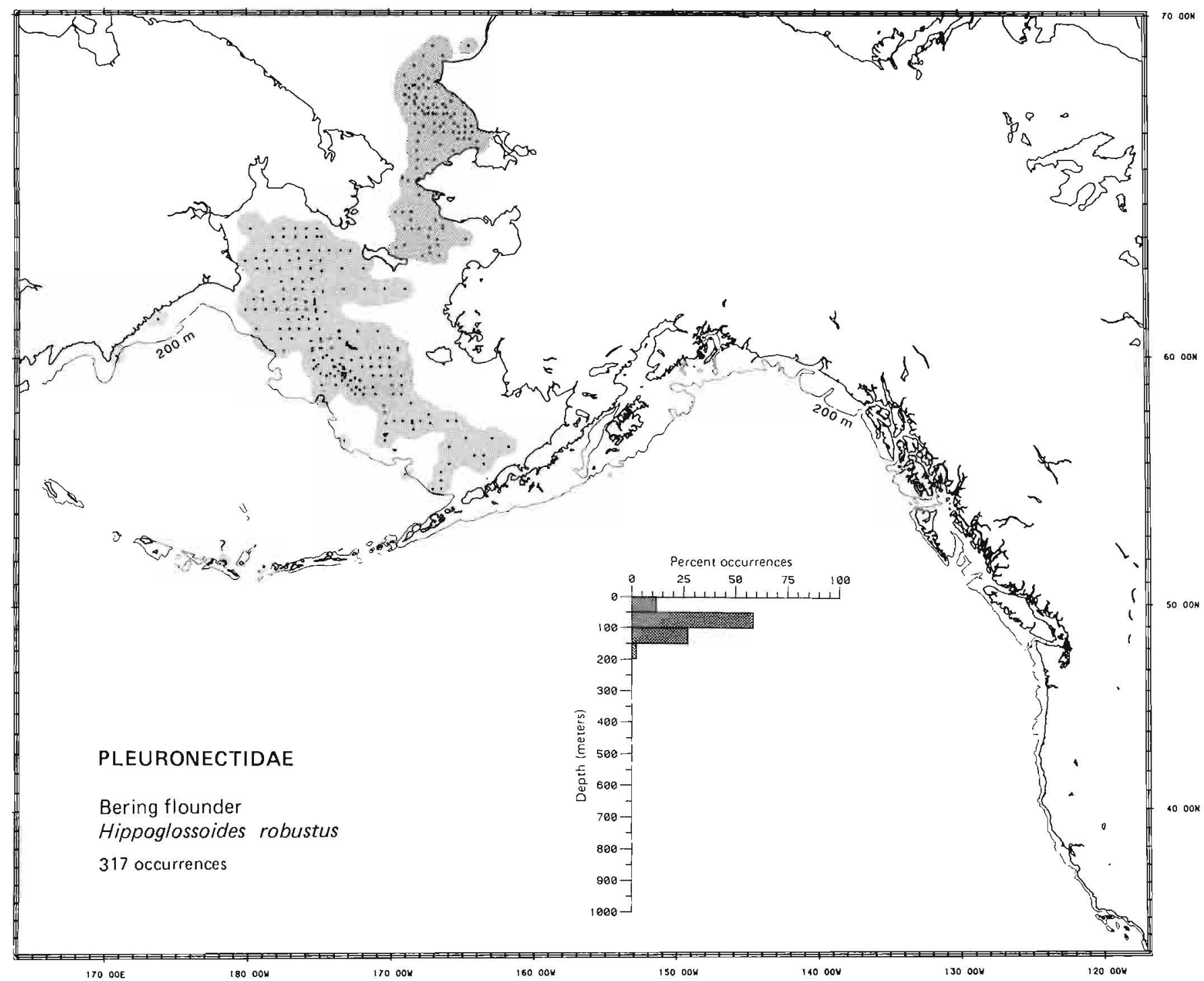


Literature Reported from the Sea of Japan off Hokkaido and the Sea of Okhotsk to the southern Anadyr Gulf and Norton Sound in the Bering Sea, west in the Aleutian Islands to Attu Island, and southeast to Point Camalu, Baja California (Andriyashev 1954; Wilimovsky 1964; Hart 1973; R. H. Rosenblatt, Scripps Inst. Oceanogr., Univ. Calif. San Diego, La Jolla, CA 92093, pers. commun. August 1984, Fish. collection no. SIO-84-1). Depth range from 6 to $1097 \mathrm{~m}$ (Miller and Lea 1972; Eschmeyer and Herald 1983).

Survey data Found from Medny Seamount and Cape Olyutorski in the western Bering Sea north to the southern Chukchi Sea, throughout the shelf of the eastern Bering Sea, and west along the Aleutian Islands to Agattu Island and Bowers Bank; from the Aleutian Islands, south to Cape Mendocino, California. Depth range 25 to $875 \mathrm{~m}$, most frequently (29.6\% of occurrences) on the middle shelf from 50 to $100 \mathrm{~m}$, and $95.5 \%$ of occurrences from depths $<300 \mathrm{~m}$. Survey data extend the northern limit of the known range.

\section{Conclusions}

Zoogeography Arctic-northeastern boreal Pacific

Life zone Inner shelf-mesobenthal (middle shelf)

Range From Hokkaido, Japan, and the Sea of Okhotsk to the southern Chukchi Sea, southeast in the Bering Sea, west along the Aleutian Islands to Attu Island and southeast to Point Camalu, Baja California

Depth 6 to $1097 \mathrm{~m}$

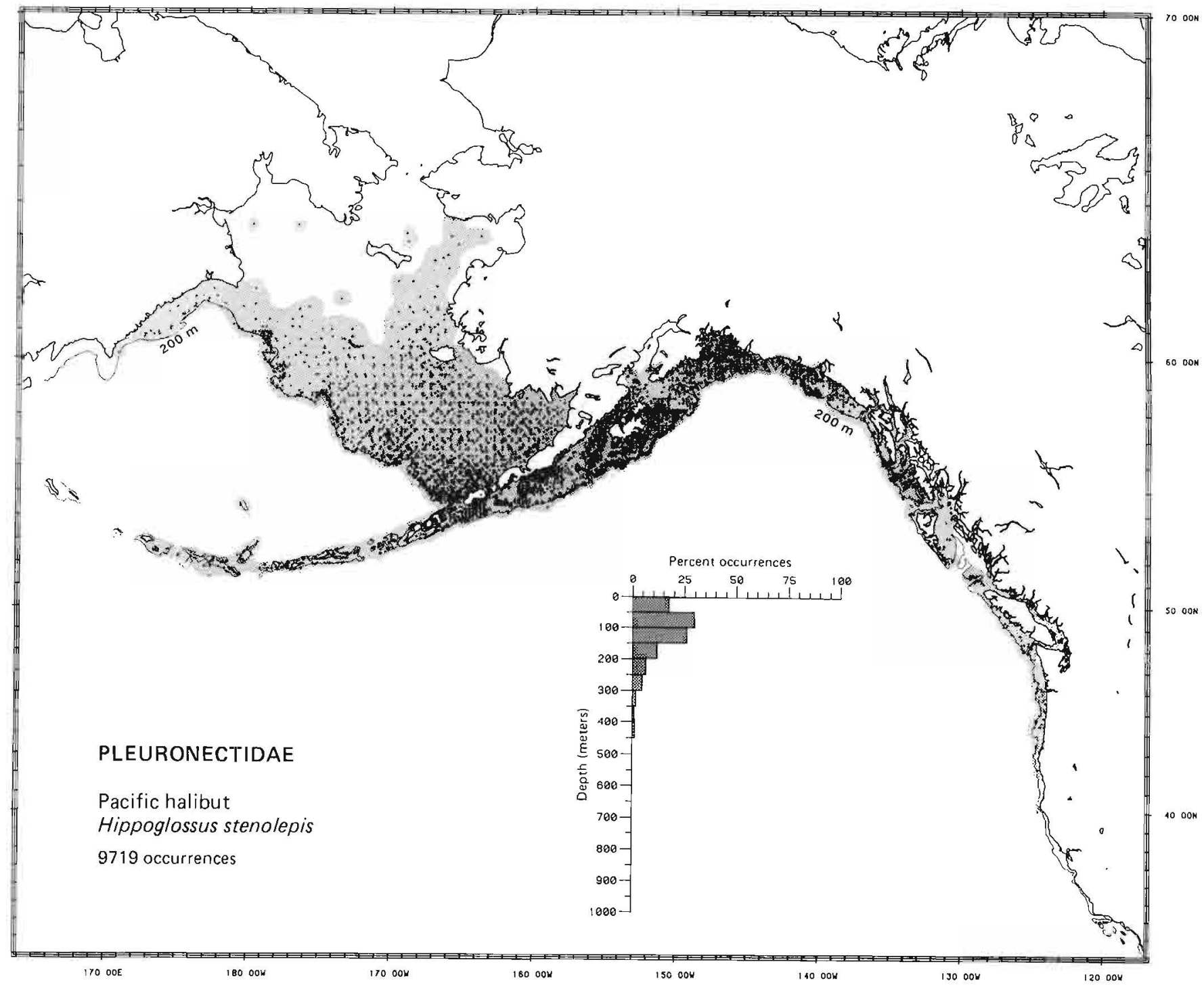


Literature Reported from the Bering Sea and in the Aleutian Islands, to San Cristobal Bay, Baja California Sur (Wilimovsky 1964; Miller and Lea 1972), at depths of 10 to $1189 \mathrm{~m}$ (Allen and Mearns 1976; Allen 1982).

Survey data Found along the outer shelf of the eastern Bering Sea from Navarin Canyon to south Bristol Bay, west along the Aleutian Islands to Stalemate Bank, and southeast to San Clemente Island, California. One questionable record occurred just south of Nunivak Island. Depth range 25 to $1025 \mathrm{~m}$, most frequently (20.7\% of occurrences) on the outer shelf between 100 and $150 \mathrm{~m}$, and $95.8 \%$ of occurrences from depths $<500 \mathrm{~m}$. Survey data provide a more detailed distribution in the Bering Sea, and extend the known range west in the Aleutian Islands.

Conclusions

Zoogeography Eastern boreal Pacific-San Diegan

Life zone Inner shelf-mesobenthal (outer shelf)

Range From Navarin Canyon in the Bering Sea west to Stalemate Bank in the Aleutian Islands, and south to San Cristobal Bay, Baja California Sur

Depth $\quad 10$ to $1189 \mathrm{~m}$

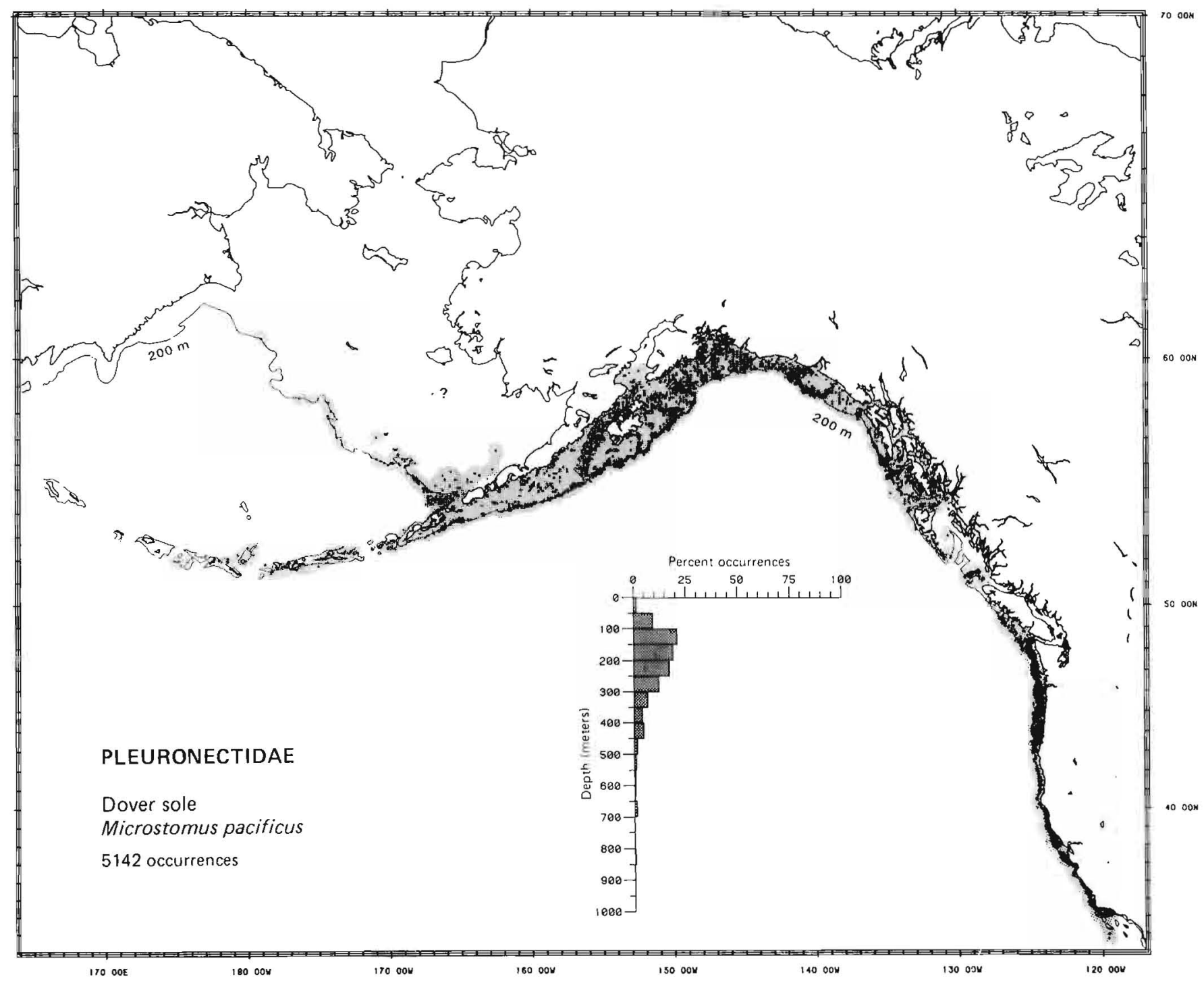


Literature Reported from Korea and the Sea of Okhotsk north to Bathurst Inlet in the Canadian Arctic, south in the Bering Sea, west to Attu Island in the Aleutian Islands, and southeast to Los Angeles Harbor, California (Wilimovsky 1964; Quast and Hall 1972; Hart 1973; Lee et al. 1980; Horn and Allen 1981). Found $120 \mathrm{~km}$ up rivers to depths of $300 \mathrm{~m}$ on the slope (Fedorov 1973a; Lee et al. 1980; Morrow 1980).

Survey data Found from the Chukchi Sea (southeast of Kivalina, Alaska), along the inner shelf of the eastern Bering Sea to Unimak Island and south to Point Reyes, California. Depth range 25 to $375 \mathrm{~m}$, most frequently (60.9\% of occurrences) on the inner shelf at depths $<50 \mathrm{~m}$, and $97.0 \%$ of occurrences from depths $<150 \mathrm{~m}$. Survey data were all within the known geographic range. However, the survey maximum depth of $375 \mathrm{~m}$ is a new record.

\section{Conclusions}

Zoogeography Arctic-circumboreal Pacific

Life zone Estuarine-sublittoral (inner shelf)

Range From Korea, Attu Island in the Aleutian Islands, and Los Angeles Harbor, California, north to Bathurst Inlet in the Depth $\quad 0$ to $375 \mathrm{~m}$

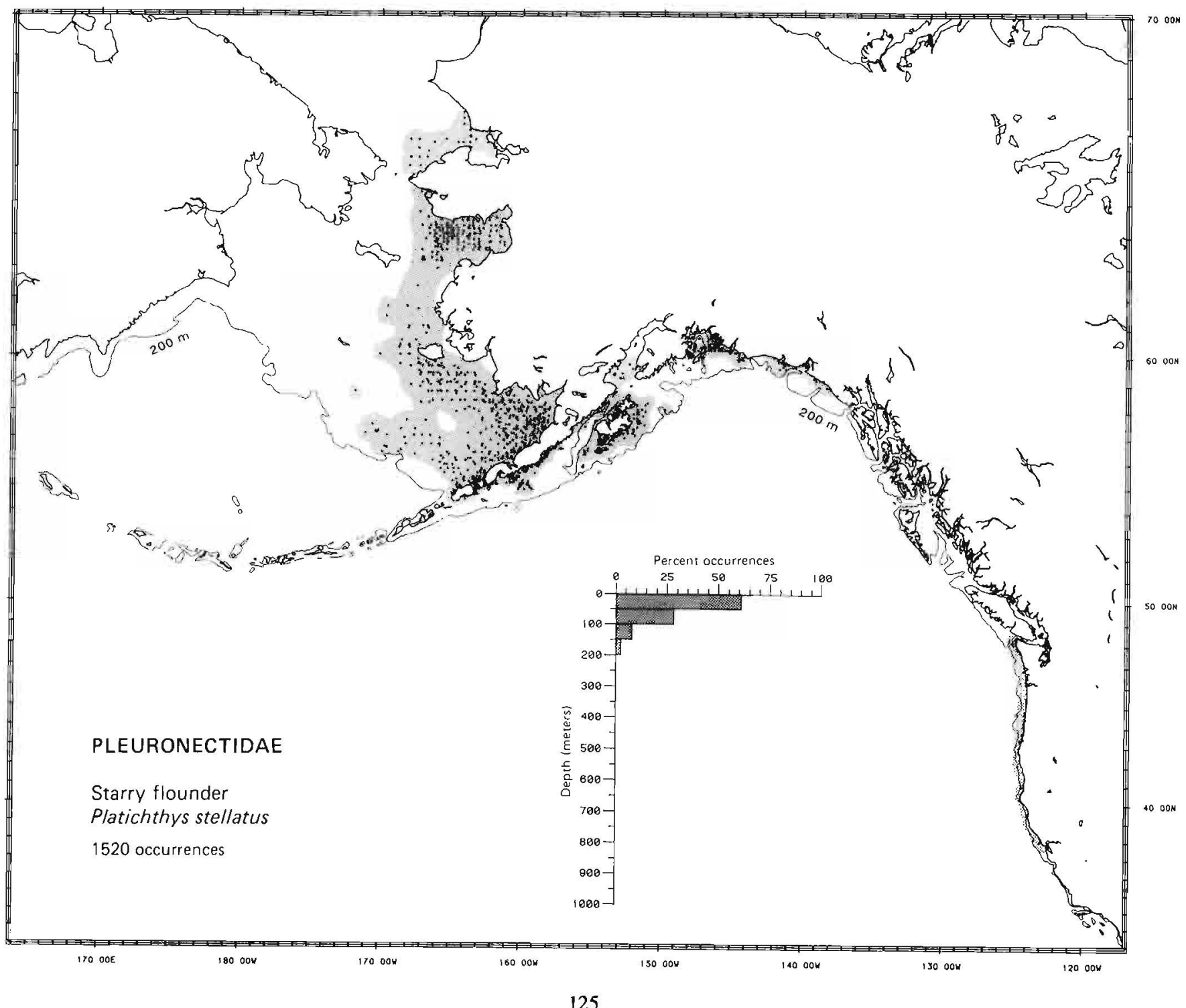


Taxonomic comment The yellowfin sole is Limanda aspera in Robins (1980), but Sakamoto (1984), the most recent revision of the family Pleuronectidae, placed the species in the genus Pleuronectes.

Literature Reported from Korea and the Sea of Okhotsk to the Chukchi Sea, southeast in the Bering Sea, west in the Aleutian Islands to Atka Island, and south to Barkley Sound in southwest Vancouver Island (Andriyashev 1954; Quast and Hall 1972; Hart 1973; Howe 1981; Eschmeyer and Herald 1983) at depths of 10 to $600 \mathrm{~m}$ (Fedorov 1973a)

Survey data Found from Bering Island and Cape Olyutorski in the western Bering Sea north to northeast of Cape Lisburne in the Chukchi Sea, south throughout the shelf of the eastern Bering Sea, and along the Aleutian Islands to Unalaska Island, from the Aleutian Islands eastward to Kayak Island in the northeastern Gulf of Alaska. Depth range 25 to $475 \mathrm{~m}$, most commonly (52.1\% of occurrences) on the middle shelf between 50 and $100 \mathrm{~m}$, and $98.7 \%$ of occurrences from depths $\leqslant 150 \mathrm{~m}$. Survey data were all within the known geographic range, although they better define the northern limits.

\section{Conclusions}

Zoogeography Arctic-northwestern boreal Pacific

Life zone Inner shelf-outer shelf (middle shelf)

Range From Korea and the Sea of Okhotsk to northeast of Cape Lisburne in the Chukchi Sea, along the Aleutian Islands to Atka Island, and south to Barkley Sound, British Columbia

Depth $\quad 10$ to $600 \mathrm{~m}$

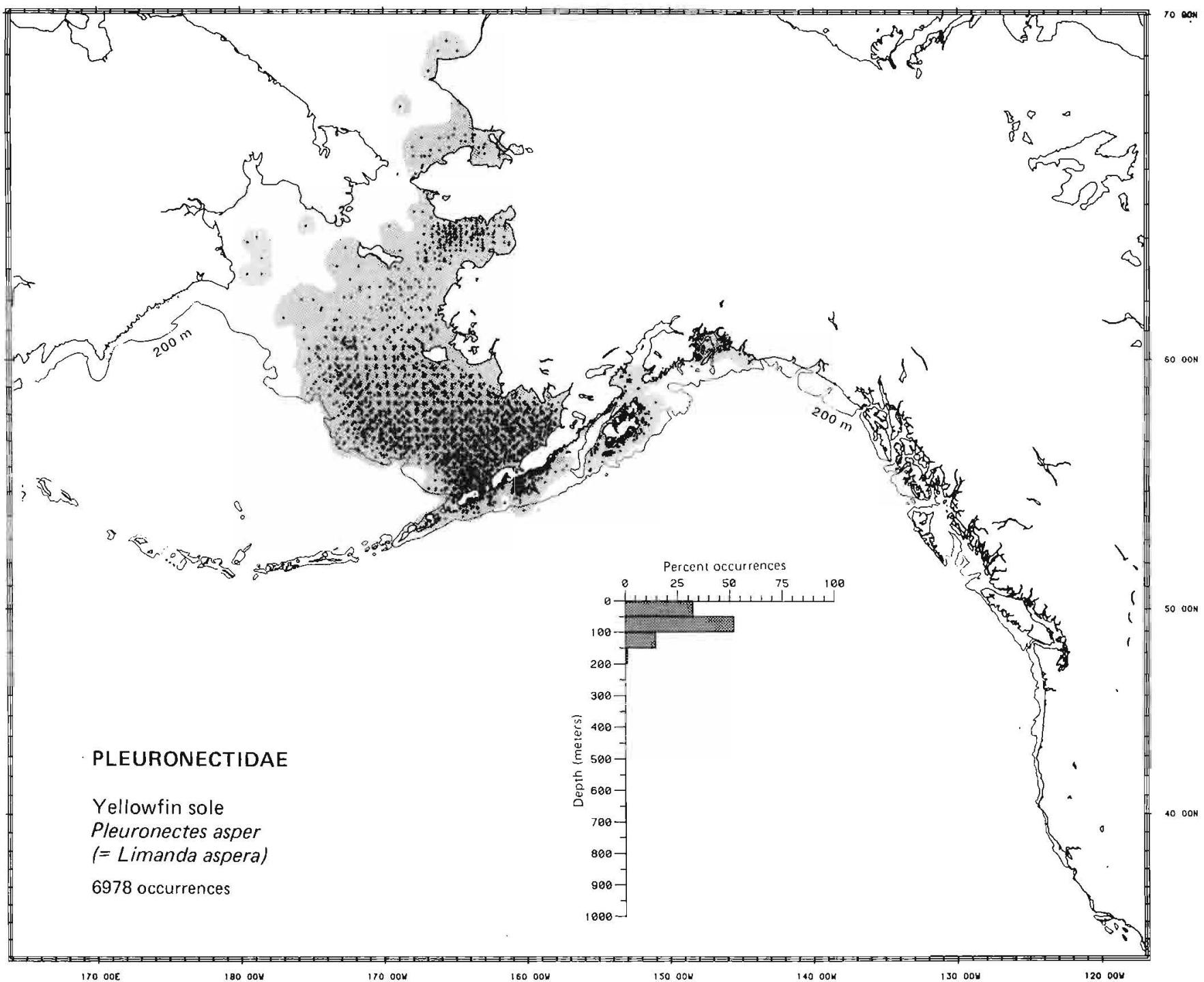


Taxonomic comment The rock sole is Lepidopsetta bilineata in Robins (1980), but Sakamoto (1984), the most recent revision of the family Pleuronectidae, placed the species in the genus Pleuronectes.

Literature Reported from Korea and the Sea of Okhotsk north to Saint Lawrence lsland in the Bering Sea, west in the Aleutian Islands to Attu Island, and south to Tanner Bank, California (Andriyashev 1954; Wilimovsky 1964; Miller and Lea 1972; Quast and Hall 1972; Alton and Sample 1976), at depths of 0 to 390 m (Fedorov 1973a; Howe 1981).

Survey data Found from Bering Island and Cape Olyutorski in the western Bering Sea, north to Saint Lawrence Island, throughout the middle and outer shelf of the eastern Bering Sea, and from Stalemate Bank in the Aleutian Islands to Point Sur, California. Depth range 25 to $575 \mathrm{~m}$, most frequently (43.6\% of occurrences) on the middle shelf between 50 to $100 \mathrm{~m}$, and $95.9 \%$ of occurrences from depths $\leqslant 200 \mathrm{~m}$. Survey data provide a more detailed distribution in the northeastern Bering Sea, extend the known range slightly westward in the Aleutians, and extend the maximum known depth.

\section{Conclusions}

Zoogeography Northeastern boreal Pacific

Life zone Inner shelf-outer shelf (middle shelf)

Range From Korea and the Sea of Okhotsk north to Saint Lawrence Island in the Bering Sea, west along the Aleutian Islands

Depth $\quad 0$ to $575 \mathrm{~m}$

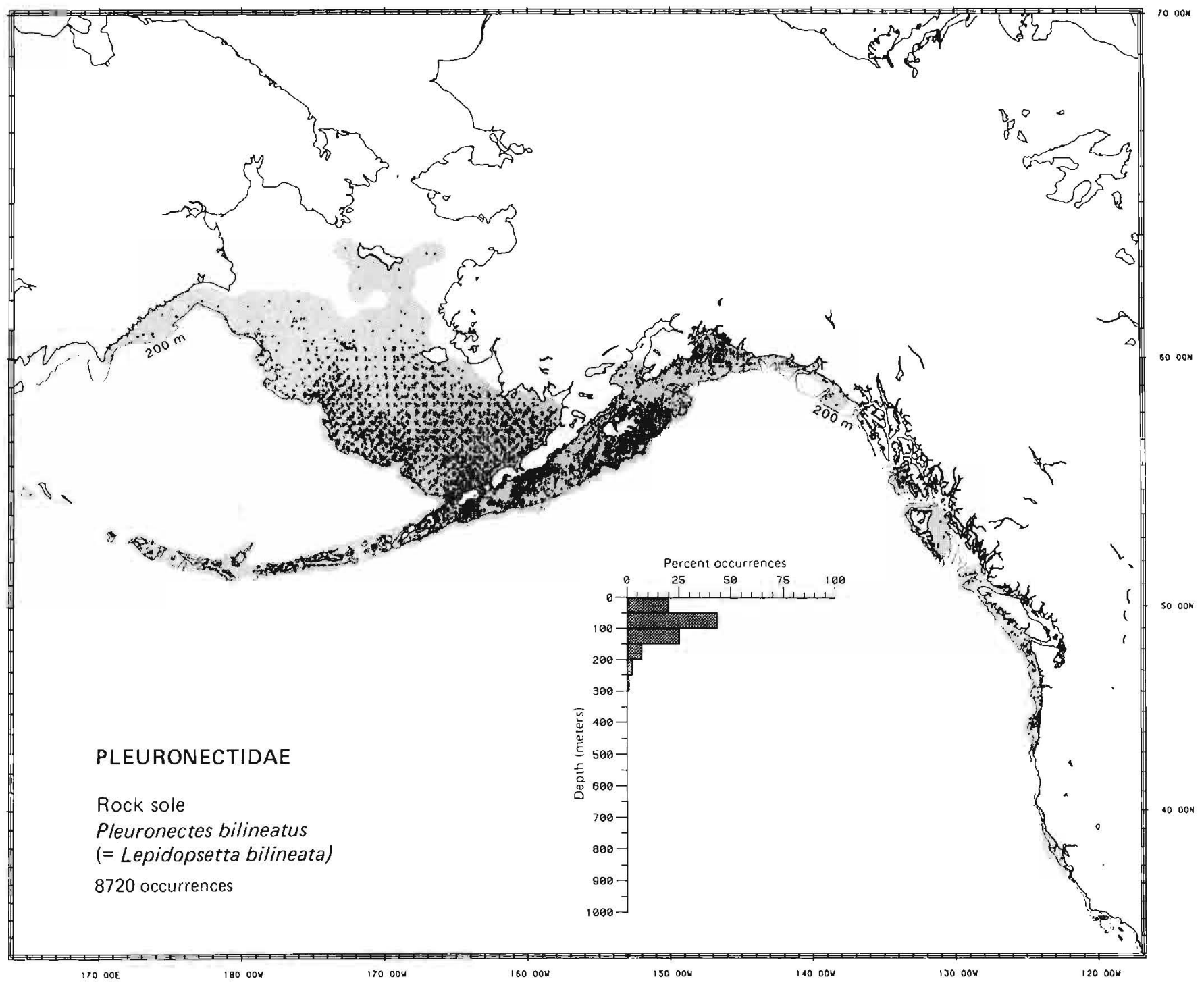


Taxonomic comment The butter sole is Isopsetta isolepis in Robins (1980), but Sakamoto (1984), the most recent revision of the family Pleuronectidae, placed the species in the genus Pleuronectes.

Literature Reported from the Bering Sea and Amchitka Island in the Aleutian Islands to Ventura, California, and from 20 to $366 \mathrm{~m}$ (Wilimovksy 1964; Quast and Hall 1972; Fedorov 1973a; Eschmeyer and Herald 1983).

Survey data Found from south of Hagemeister Island in Bristol Bay, west to Little Sitkin Island in the Aleutian Islands, and southeast to Point Reyes, California. Depth range 25 to $425 \mathrm{~m}$, most commonly (42.4\% of occurrences) on the middle shelf between 50 and $100 \mathrm{~m}$, and $94.6 \%$ of occurrences from depths $\leqslant 150 \mathrm{~m}$. Survey data provide a more detailed distribution in the southeastern Bering Sea and extend the maximum known depth. Although the species has definitely been taken from the southeastern Bering Sea (Kessler 1985), at least some fish identified in the field as butter sole in the northwestern Bering Sea were actually Sakhalin sole, Pleuronectes (=Limanda) sakhalinensis (Hubbs 1915). Records of butter sole from the following locations were considered questionable: off Dezhneva Bay (west of Cape Nizkiy) in the western Bering Sea; east of Cape Navarin; and over the outer shelf of the eastern Bering Sea, north of the Pribilof Islands.

\section{Conclusions}

Zoogeography Eastern boreal Pacific

Life zone Inner shelf-outer shelf (middle shelf)

Range From Bristol Bay in the southeastern Bering Sea and Amchitka Island in the Aleutian Islands, to Ventura, California Depth $\quad 20$ to $425 \mathrm{~m}$

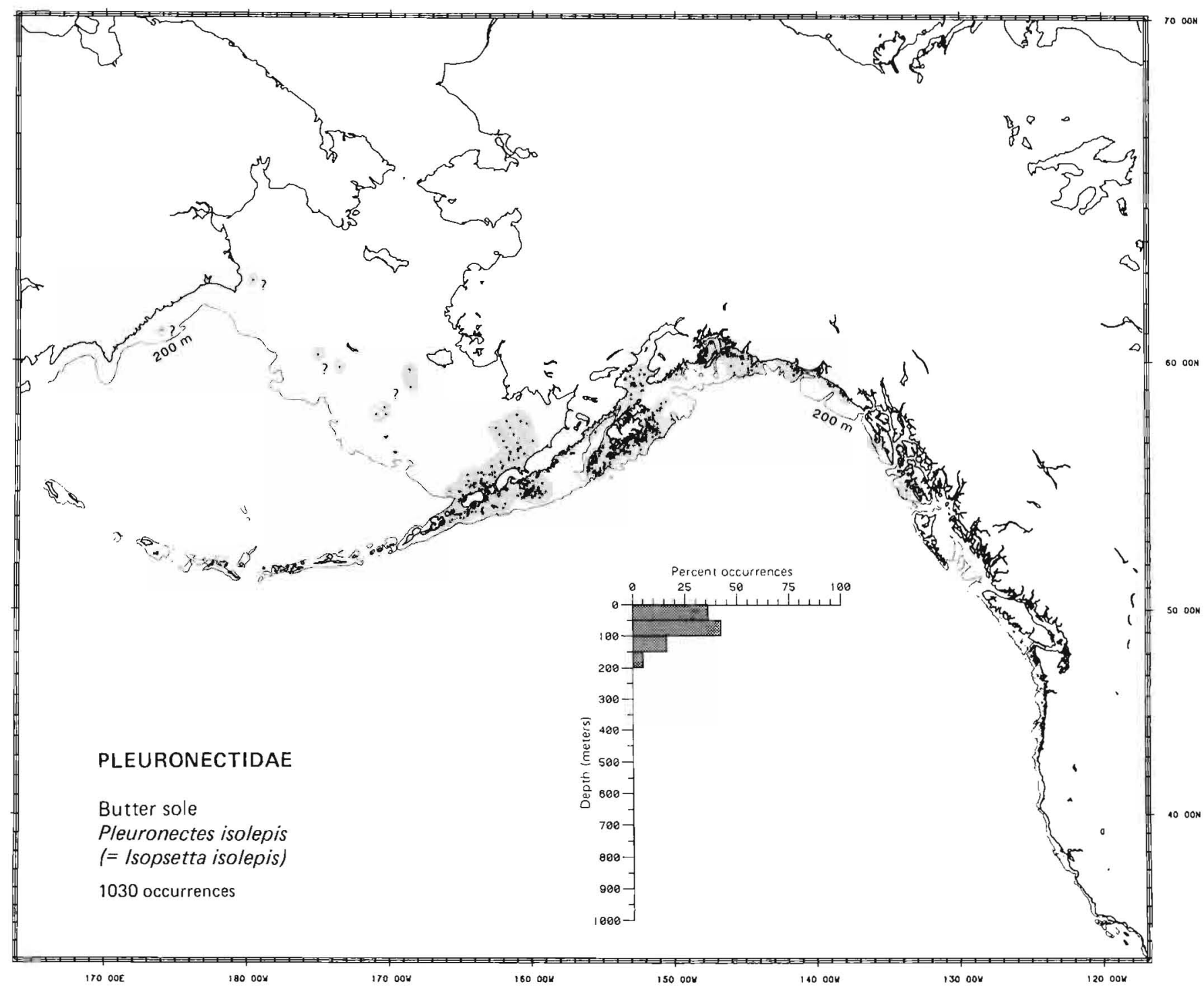


Taxonomic comment The longhead dab is Limanda proboscidea in Robins (1980), but Sakamoto (1984), the most recent revision of the family Pleuronectidae, placed the species in the genus Pleuronectes.

Literature Reported from southeast of Sakhalin in the Sea of Okhotsk, north to Kotzebue Sound in the Chukchi Sea, south to Unimak Island (Shmidt 1950; Andriyashev 1954; Wolotira et al. 1977), and in depth from 10 to $91 \mathrm{~m}$ (Howe 1981; data on file, Northwest and Alaska Fish. Cent., Natl. Mar. Fish. Serv., NOAA, Seattle, WA 98115).

Survey data Found at one station off Cape Nizkiy on the Korak Coast of the western Bering Sea, and from Cape Krusenstern (northern Kotzebue Sound) to Unimak Island. Depth range 25 to $125 \mathrm{~m}$, most frequently $(63.2 \%$ of occurrences) on the inner shelf at depths $<50 \mathrm{~m}$, and $99.9 \%$ of occurrences from depths $\leqslant 100 \mathrm{~m}$. Survey data were all within the known geographic range, but the maximum known depth was extended slightly.

\section{Conclusions}

Zoogeography Arctic-northern boreal Pacific (Okhotsk)

Life zone Inner shelf-middle shelf (inner shelf)

Range $\quad$ From the Sea of Okhotsk to Cape Krusenstern in Kotzebue Sound and south to Unimak Island

Depth $\quad 10$ to $125 \mathrm{~m}$

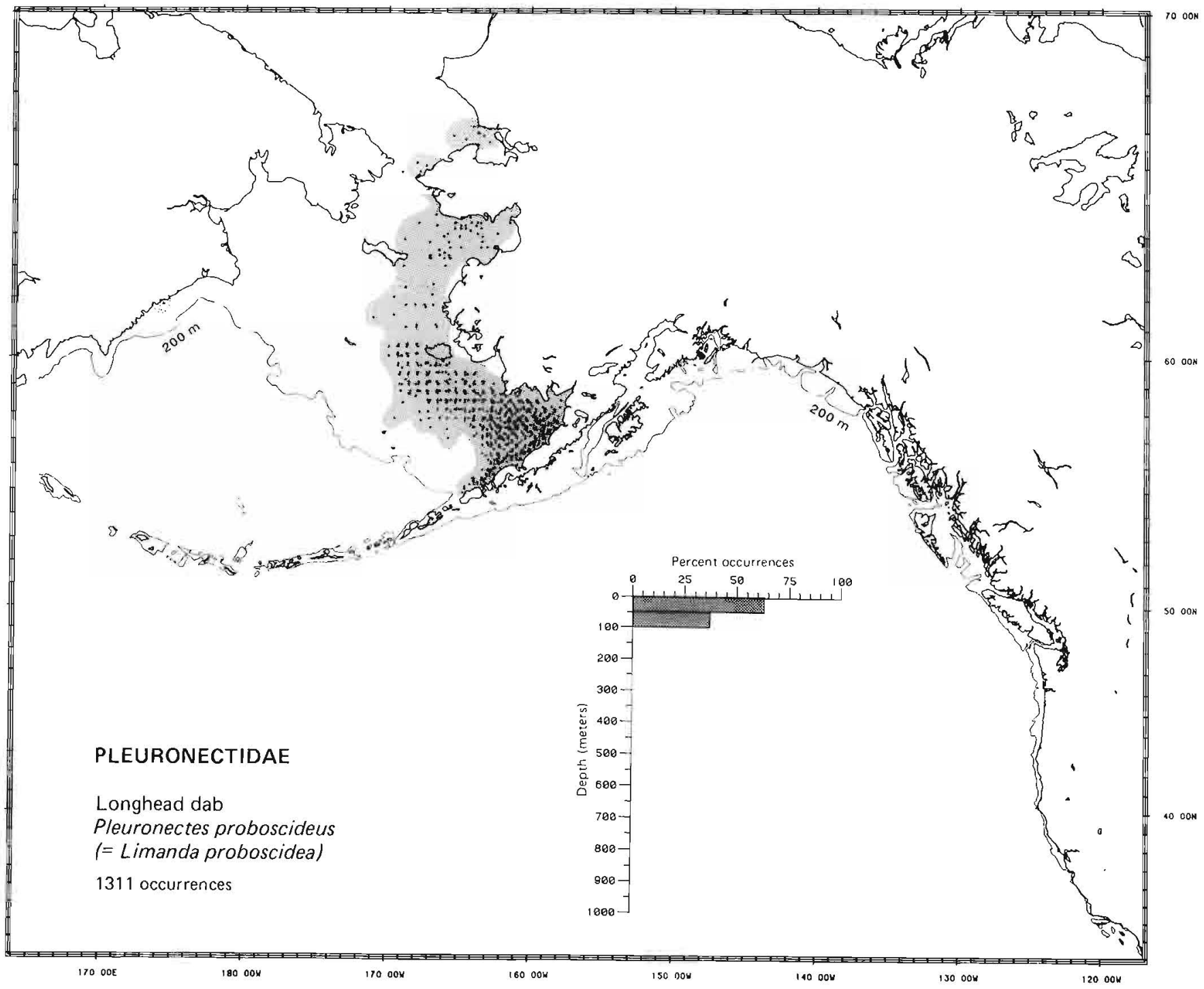


Literature Reported from Peter the Great Bay in the Sea of Japan to the Bering Strait, southeast in the Bering Sea, west in the Aleutian Islands to Unalaska Island, and east to Prince William Sound, Alaska (Andriyashev 1954; Wilimovsky 1964; Quast and Hall 1972), at depths of 6 to $300 \mathrm{~m}$ (Andriyashev 1954; Howe 1981).

Survey data Taken from Cape Olyutorski in the western Bering Sea north to Point Hope in the Chukchi Sea, south along the inner and middle shelf of the eastern Bering Sea to Unimak Island, and east to Kayak Island in the northeastern Gulf of Alaska. Depth range 25 to $475 \mathrm{~m}$, most commonly ( $55.3 \%$ of occurrences) on the middle shelf from 50 to $100 \mathrm{~m}$, and $98.6 \%$ of occurrences from depths $<150 \mathrm{~m}$. Survey data extend the known range north to Point Hope and east to Kayak Island and the maximum known depth.

\section{Conclusions}

Zoogeography Arctic-northern boreal Pacific

Life zone Inner shelf-outer shelf (middle shelf)

Range From Peter the Great Bay in the west to Point Hope in the Chukchi Sea, south to Unalaska Island, and east to Kayak Island in the northeastern Gulf of Alaska

Depth 6 to $475 \mathrm{~m}$

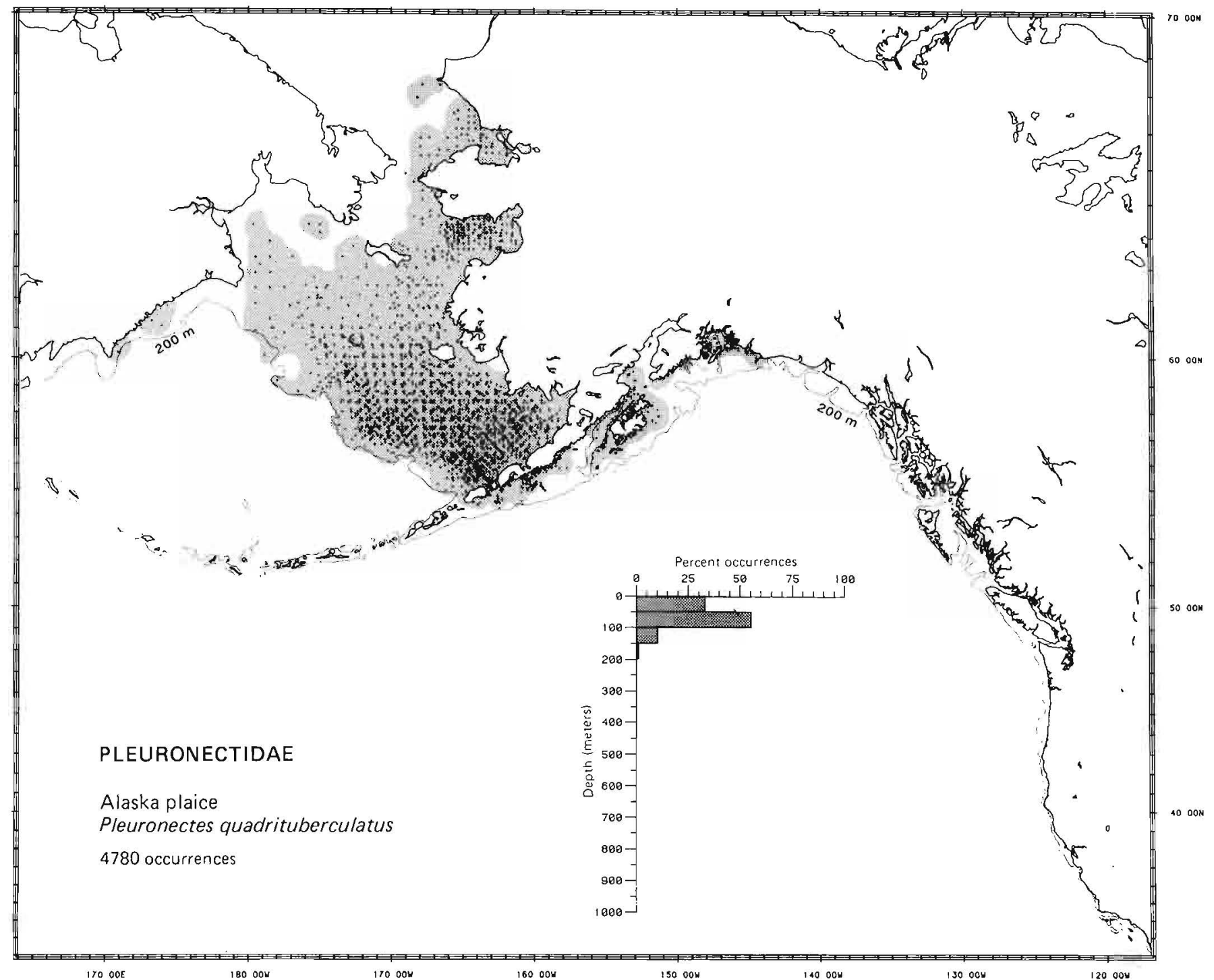


Taxonomic comment The English sole is Parophrys vetulus in Robins (1980), but Sakamoto (1984), the most recent revision of the family Pleuronectidae, placed the species in the genus Pleuronectes.

Literature Reported from Unimak Island in the Bering Sea, to San Cristobal Bay, Baja California Sur (Miller and Lea 1972; Hart 1973), at depths of 0 to $550 \mathrm{~m}$ (Hart 1973).

Survey data Found from Agattu Island in the Aleutian Islands north to Nunivak Island in the eastern Bering Sea and southeast to the Santa Barbara Channel, California. Depth range 25 to $475 \mathrm{~m}$, most frequently (34.2\% of occurrences) on the middle shelf from 50 to $100 \mathrm{~m}$, and $94.7 \%$ of occurrences from depths $<250 \mathrm{~m}$. Survey data extend the known range along the Aleutian Islands and define the distribution in the Bering Sea.

\section{Conclusions}

Zoogeography Eastern boreal Pacific-San Diegan

Life zone Inner shelf-mesobenthal (middle shelf)

Range From Agattu Island in the Aleutian Islands and Nunivak Island in the eastern Bering Sea to San Cristobal Bay, Baja California Sur

Depth $\quad 0$ to $550 \mathrm{~m}$

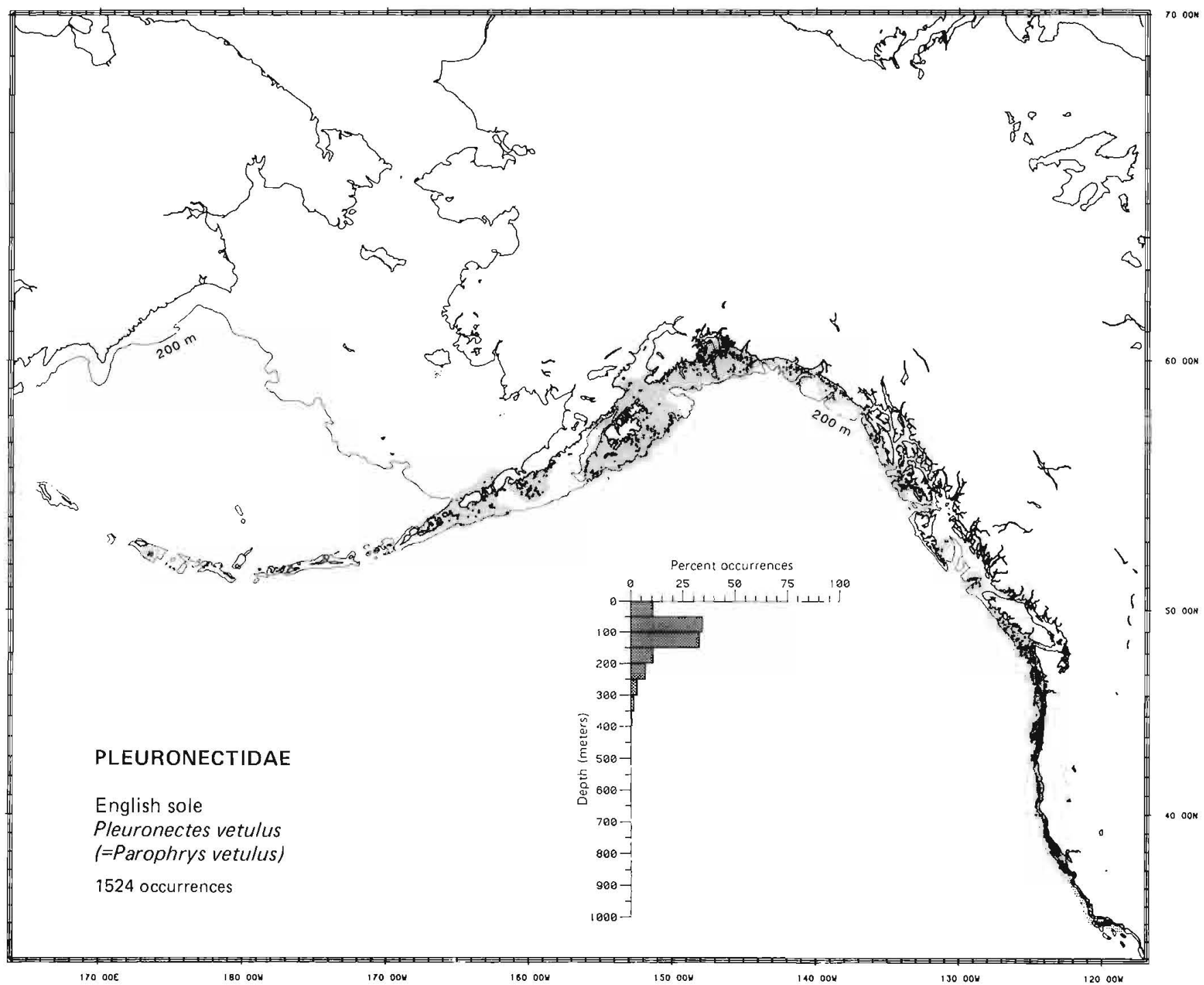


Literature Reported from the Bering Sea to Redondo Beach, California, from 1 to $183 \mathrm{~m}$ in depth (Miller and Lea 1972; Howe 1981).

Survey data Found from Unalaska Island in the Aleutian Islands, north in the southeastern Bering Sea to northwest of Port Heiden, Bristol Bay, and southeast to Eureka, California. Depth range 25 to $325 \mathrm{~m}$. most frequently (63.4\% of occurrences) on the inner shelf at depths $<50 \mathrm{~m}$, and $97.3 \%$ of occurrences from depths $<150 \mathrm{~m}$. Survey data define the northern and western limits of the range more precisely, extend the known range in the Aleutians, and provide a new survey maximum depth of $325 \mathrm{~m}$. Although the species occurs in the southeastern Bering Sea, the Sakhalin sole, Pleuronectes sakhalinensis, may have been confused with this species in regions to the northwest (see account of butter sole, Pleuronectes isolepis, for further information on this problem). Records of sand sole that were considered questionable occurred east of Saint Matthew Island and Saint George Island.

\section{Conclusions}

Zoogeography Eastern boreal Pacific

Life zone Inner shelf-outer shelf (inner shelf)

Range From Unalaska Island, and Port Heiden in the Bering Sea to Redondo Beach, California

Depth 1 to $325 \mathrm{~m}$

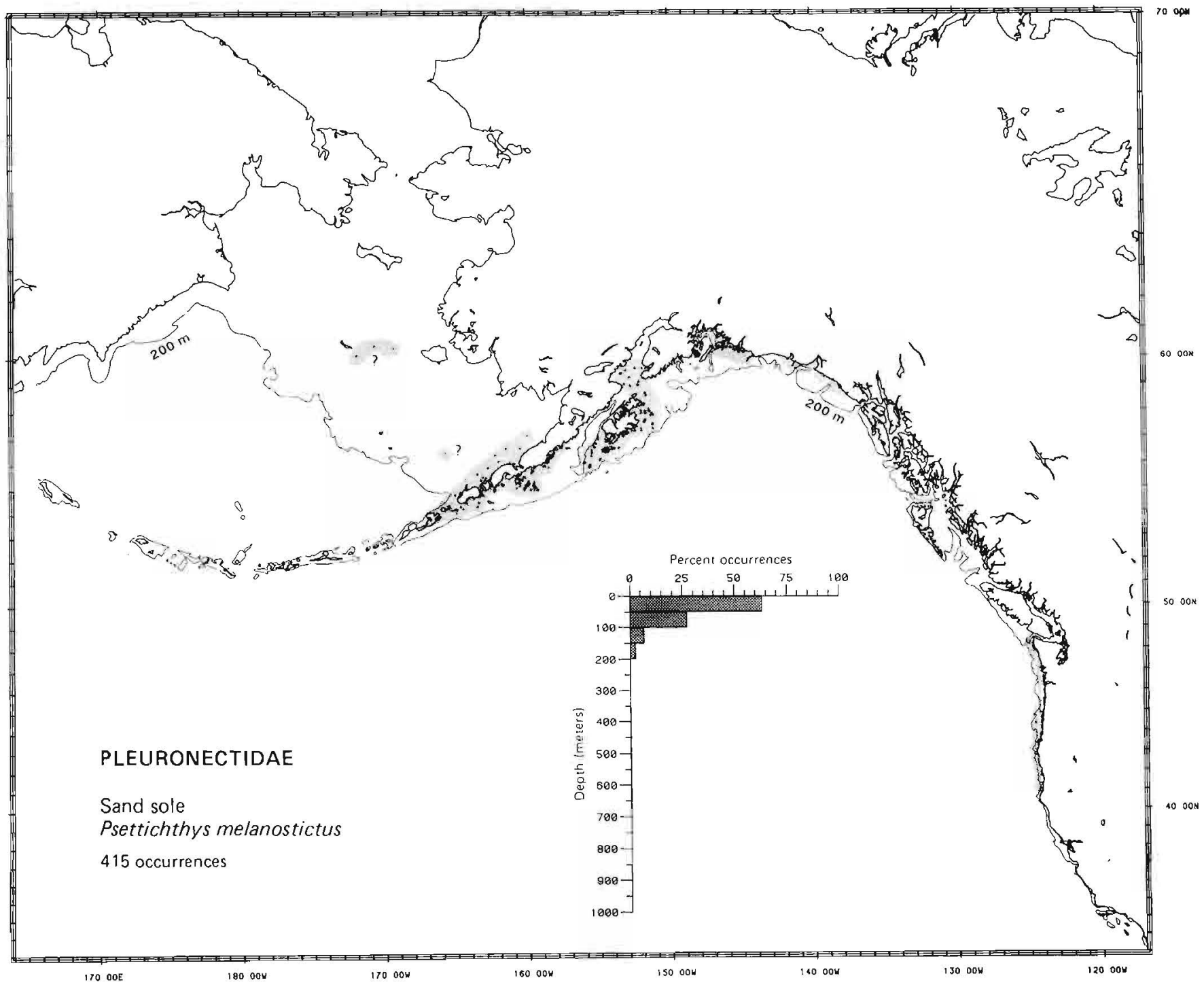


Literature Reported in the Pacific from the Sea of Japan off Honshu, the Sea of Okhotsk, along the Aleutian Islands, north to the Chukchi Sea, southeast to northern Baja California (Shmidt 1950; Miller and Lea 1972; Quast and Hall 1972; Hart 1973; Howe 1981); in the North Atlantic from New Jersey to southern Baffin Isiand, northwest Greenland, Iceland, Spitsbergen, and the Barents Sea and from there south to Ireland (Leim and Scott 1966; Quast and Hall 1972; Muus 1974), from 14 to $2000 \mathrm{~m}$ in depth (Miller and Lea 1972; Muus 1974).

Survey data Found from Medny Seamount and Cape Olyutorski in the western Bering Sea to Shishmaref, Alaska, in the Chukchi Sea, and along the outer shelf of the eastern Bering Sea, along the Aleutian Islands from Stalemate Bank, Ulm Plateau, and Bowers Bank eastward to Cross Sound, southeastern Alaska. Depth range 25 to $1025 \mathrm{~m}$, most frequently $(35.7 \%$ of occurrences) on the middle shelf from 50 to $100 \mathrm{~m}$, and $95.3 \%$ of occurrences from depths $<600 \mathrm{~m}$. Survey data were all within the known geographic and depth ranges.

\section{Conclusions}

Zoogeography Arctic-amphiboreal (circumboreal Atlantic-northern boreal Pacific)

Life zone Inner shelf-bathybenthal (middle shelf)

Range In the North Pacific, from the Sea of Japan off Honshu north to Shishmaref, Alaska in the Chukchi Sea, throughout the Aleutian Islands, and southeast to northern Baja California. In the North Atlantic, from New Jersey to Spitsbergen and the Barents Sea and from there south to Ireland

Depth 14 to $2000 \mathrm{~m}$

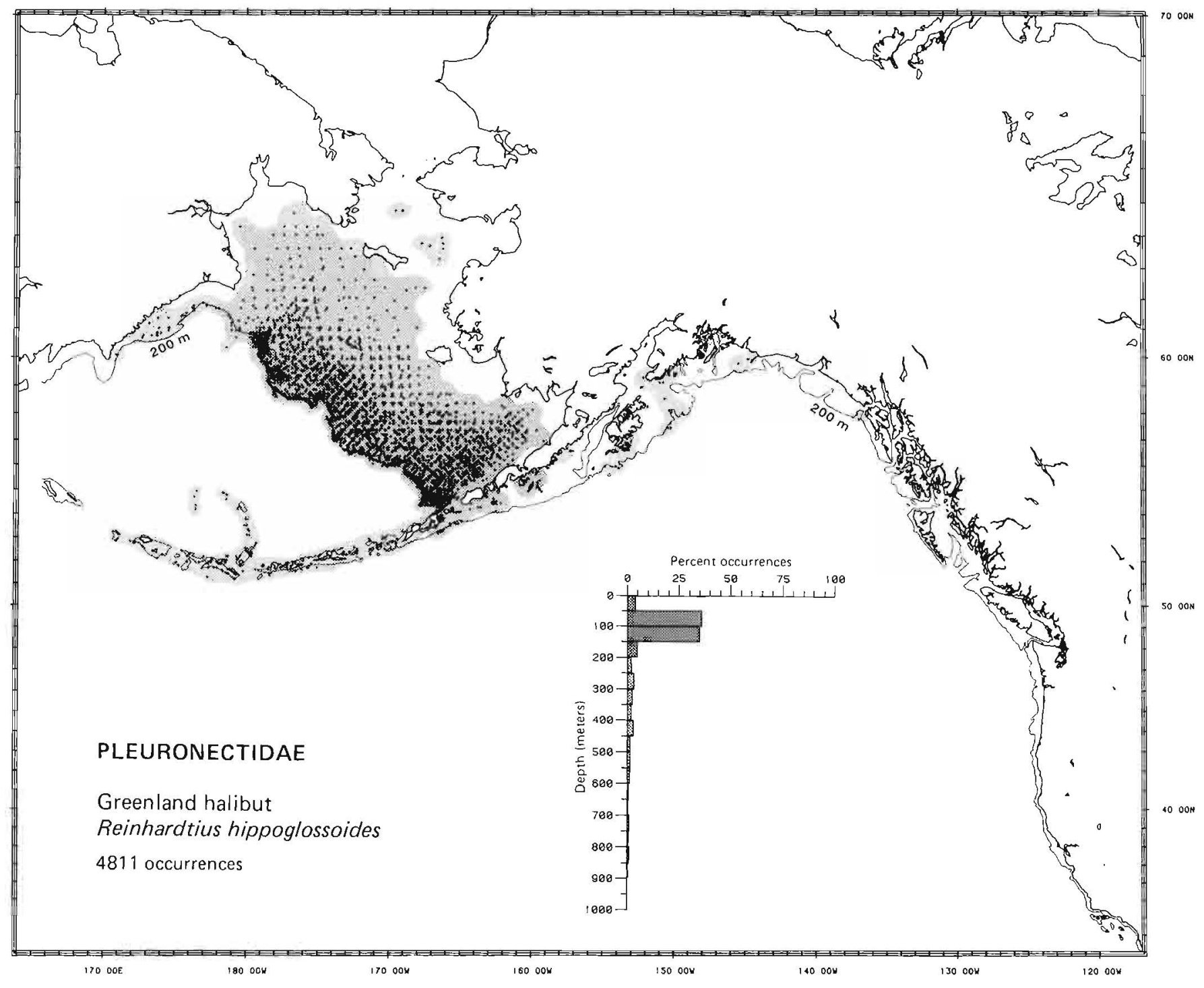




\section{EXTENSIONS OF KNOWN RANGES}

The survey data provided extensions of known range (geographic, depth, or both) for 111 species or $91.7 \%$ of the total (121 species) in the survey (Table 5). Extensions to the north, to greater depths, and in the Aleutian Islands were the most frequent; 74 species (61.2\% of the total) had extensions to the north, $71(58.7 \%)$ had new maximum depth records, and $43(35.5 \%)$ had new extensions in the Aleutian Islands.

These extensions of known range, however, were sometimes questionable. Forty- three represented a more specific location than that mentioned in the general literature. In these cases, a more detailed examination of the literature may show that some of these are not new records. Thirty-eight of the northern, four of the Aleutian, and one southern extension fell into this category.
In 17 cases, the extension may not be real because the record may actually be that of another species and hence may represent a misidentification. Nine of the northern, three of the Aleutian, three shallow, and two deep extensions fell into this category.

Another category includes pelagic species that may have been taken near the surface over deep water. For these species, the maximum depth records found here may overestimate their true maximum depth of occurrence. Seven species fell into this category.

A fourth category includes anomalous distributions (i.e., those records that are questionable because they occur far outside the normal range of the species). Three of the northern, three of the deepwater, two of the shallow, and one of the southern extensions fell into this category.

Table 5

Species for which the known geographic and/or depth ranges were extended by the surveys.* West = western Bering Sea south of Cape Navarin; North and East/South $=$ anywhere along the west coast of America or the eastern Bering Sea; Aleutian = westward extension in the Aleutians.

\begin{tabular}{|c|c|c|c|c|c|c|c|c|c|c|c|c|c|}
\hline \multirow[b]{2}{*}{ Species } & \multicolumn{4}{|c|}{ Geographic range } & \multicolumn{2}{|c|}{ Depth range } & \multirow[b]{2}{*}{ Species } & \multicolumn{4}{|c|}{ Geographic range } & \multicolumn{2}{|c|}{ Depth range } \\
\hline & West & North & Aleutian & $\begin{array}{l}\text { East/ } \\
\text { South }\end{array}$ & $\begin{array}{l}\text { Mini- } \\
\text { mum }\end{array}$ & $\begin{array}{l}\text { Max- } \\
\text { inum }\end{array}$ & & West & Norih & Aleutian & $\begin{array}{l}\text { East/ } \\
\text { South }\end{array}$ & $\begin{array}{l}\text { Mini- } \\
\text { mum }\end{array}$ & $\begin{array}{l}\text { Max- } \\
\text { imum }\end{array}$ \\
\hline Hydrolagus colliei & - & A & - & - & - & - & Sebastolobus alascanus & - & A & + & - & - & - \\
\hline Squalus acanthias & - & + & - & - & - & - & Anoplopoma fimbria & - & A & - & - & - & - \\
\hline Torpedo californica & - & - & - & - & - & + & Hexagrammos stelleri & - & A & - & - & - & $\mathrm{D}$ \\
\hline Bathyraja interrupta & - & B & B & - & $\mathrm{B}$ & - & Ophiodon elongatus & - & - & - & - & - & + \\
\hline Raja binoculatua & - & A & + & - & - & - & Pleurogrammus monopterygius & - & + & - & - & - & + \\
\hline R. rhina & - & + & - & - & + & + & Eumicrotremus orbis & - & - & - & - & - & + \\
\hline Alosa sapidissima & - & - & - & - & - & $\mathrm{C}$ & Dasycothus setiger & - & A & + & - & - & + \\
\hline Clupea pallasii & - & - & - & - & - & $\mathrm{C}$ & Malacocontus kincaidi & - & B & $\mathrm{B}$ & $\rightarrow$ & - & $\mathrm{B}$ \\
\hline Mallotus villosus & - & - & - & - & - & $\mathrm{C}$ & M. Ionurus & - & B & $\mathrm{B}$ & - & B & - \\
\hline Osmerus mordax & - & - & - & - & - & $\mathrm{C}$ & Aspidophoroides barroni & - & - & - & A & - & + \\
\hline Thaleichthys pacificus & - & + & + & - & - & $\mathrm{C}$ & Balhyagonus nigripinnis & - & A & A & - & - & - \\
\hline Oncorhynchus ishawytscha & - & - & - & - & - & $\mathrm{C}$ & Occella dodecaedrom & - & + & + & - & - & + \\
\hline Chauliodus macouni & - & A & - & - & + & - & O. verrucosa & - & B & - & - & - & + \\
\hline Albatrossia pectoralis & - & - & - & - & $\mathrm{D}$ & - & Polothecus acipenserinus & - & - & - & + & - & + \\
\hline Coryphaenoides cinereus & - & A & + & - & + & - & Sarritor frenatus & - & + & + & - & - & + \\
\hline Boreogadus saida & - & - & - & + & - & + & Hemitripterus bolini & + & - & + & - & + & + \\
\hline Eleginus gracilis & - & + & - & - & - & + & Enophrys diceraus & - & A & - & - & + & + \\
\hline Gadus macrocephalus & - & - & - & - & - & + & Gymnocanthus galeatus & - & A & + & - & - & D \\
\hline Microgadus proximus & - & $A$ & - & - & - & + & G. pistilliger & - & - & - & - & - & + \\
\hline Theragra chalcogramma & - & A & - & - & - & + & G. Iricuspis & - & - & + & - & - & $\mathrm{D}$ \\
\hline Antimora microlepis & - & + & + & - & D & - & Hemilepidotus hemilepidotus & - & $\mathrm{B}$ & - & - & - & + \\
\hline Sebastes aleutianus & - & A & A & - & + & + & H. jordani & - & + & - & - & + & + \\
\hline S. alutus & - & + & + & - & - & + & H. papilio & - & - & + & - & - & + \\
\hline S. aurora & - & - & - & - & + & - & Icelinus filamentosus & - & + & - & - & - & - \\
\hline S. babcocki & - & A & - & - & - & + & leelus canaliculatus & - & $A$ & + & - & - & + \\
\hline S. borealis & - & $A$ & A & + & - & + & I. spiniger & - & A & + & - & + & - \\
\hline S. brevispinis & - & - & - & - & - & + & Myorocephalus jaok & - & A & - & - & - & - \\
\hline S. ciliarus & - & A & A & - & - & + & M. polyacanthocephalus & - & + & - & - & - & + \\
\hline S. crameri & - & A & + & - & + & - & Triglops forficara & + & + & + & + & - & + \\
\hline S. elongatus & - & + & - & - & + & + & T. inacellus & + & A & - & - & - & + \\
\hline S. entomelas & - & + & - & - & - & + & T. pingeli & - & - & + & - & - & - \\
\hline S. flavidus & - & + & - & - & - & - & T. scepticus & - & $A$ & + & - & + & + \\
\hline S. goodei & - & + & - & - & - & + & Zalembius rosaceus & - & + & - & - & - & - \\
\hline S. helvomaculatus & - & - & - & - & + & - & Bathymaster signatus & - & - & + & - & - & + \\
\hline$S$. jordani & - & $\mathrm{D}$ & - & - & - & - & Runquilus jordani & - & $A$ & - & - & - & + \\
\hline S. melanosiomus & - & B & - & - & $\mathrm{B}$ & - & Bothrocara brunneum & - & + & + & - & + & - \\
\hline S. paucispinis & - & + & - & - & - & + & Lycodes brevipes & - & - & + & + & + & - \\
\hline$S$ pinniger & - & + & - & - & - & + & L. concolor & - & A & + & - & - & + \\
\hline S. polyspinis & - & A & + & - & - & + & L. conteziunus & - & $\mathrm{D}$ & - & - & - & - \\
\hline S. proriger & - & A & - & - & - & + & L. diapterus & - & A & + & - & - & - \\
\hline S. ruberrimus & - & A & - & - & + & - & L. palearis & - & - & + & - & - & + \\
\hline S. rubrivinctus & - & B & - & - & - & B & L. raridens & - & - & - & + & + & + \\
\hline S. saxicola & - & D & - & - & - & - & L. turneri & - & - & - & + & + & + \\
\hline S. variegatus & - & - & + & D & - & - & Lumpenella longirosiris & - & A & + & - & + & + \\
\hline S. zacentrus & - & - & + & - & + & + & Lumpenus fabricii & - & - & - & - & - & + \\
\hline
\end{tabular}




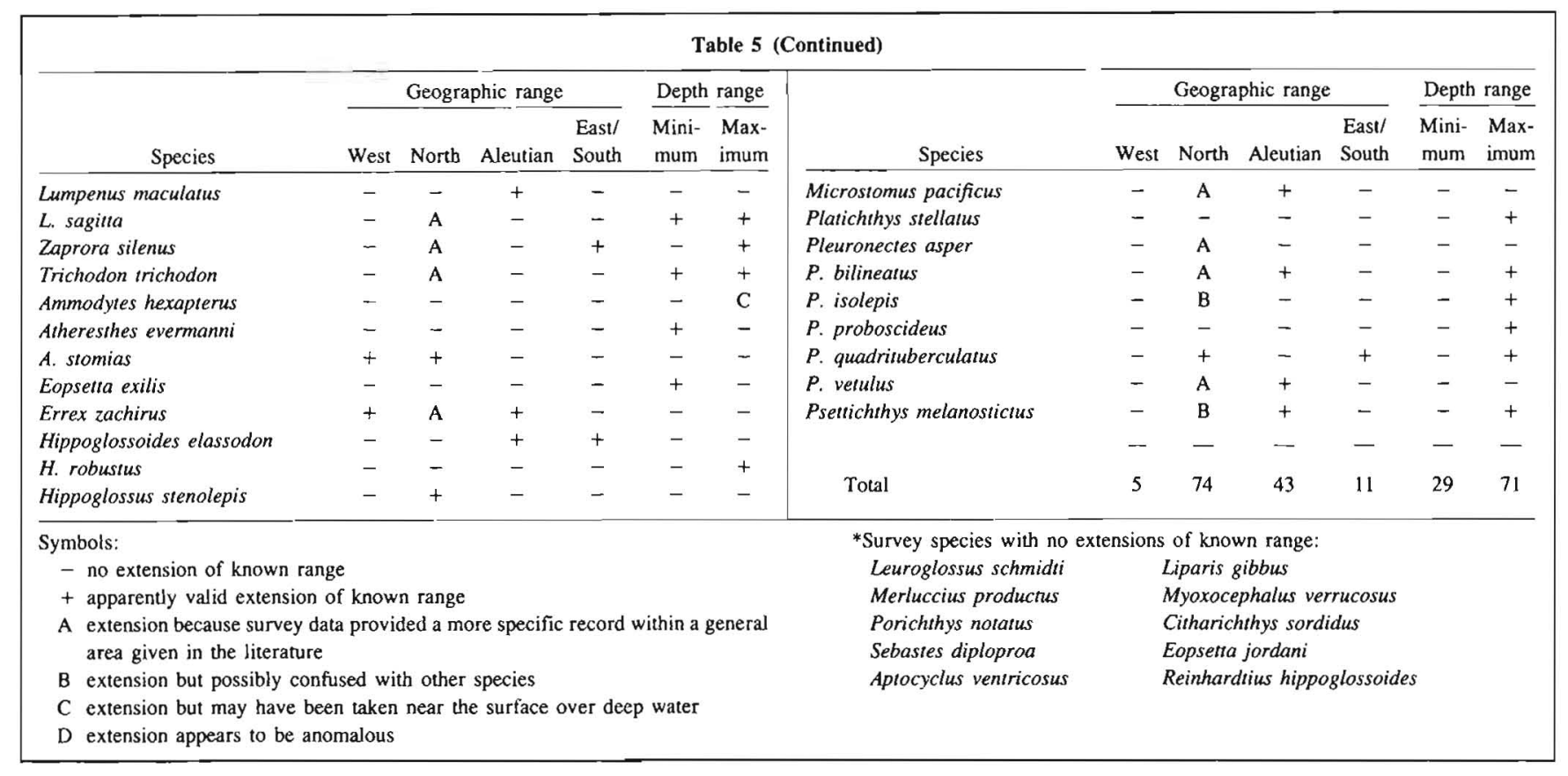

\section{ZOOGEOGRAPHIC AND LIFE ZONE CLASSIFICATION}

\section{Zoogeographic groups}

As might be expected from the area covered, all species examined had Arctic and/or temperate North Pacific affinities. Of 121 species (excluding three species complexes) $71(58.7 \%)$ were boreal, 33 (27.3\%) had ranges extending into the Arctic, and 17 (14.0\%) were temperate (Table 6).

Species with Arctic affinities had distributions that fell into the following major classes: 1) Arctic; 2) Arctic-Boreal Atlantic; 3) Arctic-Amphiboreal; and 4) Arctic-Boreal Pacific. By far the greatest number (24) of species were Arctic-Boreal Pacific, followed by Arctic-Amphiboreal with five, Arctic-Boreal Atlantic with three, and Arctic with one. Of the Arctic-Boreal Pacific species, the greatest number of species (6) were Arctic-Northern Boreal Pacific, followed by Arctic-Okhotsk and Arctic-circumboreal Pacific with five each.

Species with boreal affinities had distributions that fell into the following major classes: 1) Amphiboreal-American, and 2) Boreal Pacific. Only one species (which was introduced to the Pacific Coast from the Atlantic) showed an Amphiboreal-American distribution, and 70 were Boreal Pacific. Of the Boreal Pacific species, the greatest number (35) were Eastern Boreal Pacific, followed by Northern Boreal Pacific with ten, and Kurile-Aleutian with eight.

Species with temperate affinities comprised two major groups: 1) Antitropical Temperate, with a single species, and 2) Temperate North Pacific, with 16 species. Of this latter category, 15 were Eastern Temperate Pacific with various combinations of provinces. The greatest number of species (10) had Oregonian-San Diegan distributions.

\section{Life zone and depth zone groups}

Because most samples from the surveys were taken with demersal trawls, most $(109 ; 90.1 \%$ of the total) of the species were demersal and $12(9.9 \%)$ were pelagic. Of the 121 species, four (3.3\%) had freshwater affinities, two (1.6\%) had estuarine affinities, and one $(0.8 \%)$ had intertidal affinities (Table 7$)$. The greatest number (62) of species were sublittoral-bathyal, followed by sublittoral with 38 , and bathyal with seven, neritic-oceanic with five, and oceanic with two. The life zones with the greatest number of species were inner shelf-outer shelf with 27 , middle shelf-mesobenthal with 23 , and inner shelf-mesobenthal with 20.

In terms of the depth zone of modal occurrence, the greatest number $(47 ; 38.8 \%$ of the total) of species were found on the outer shelf, $27(22.3 \%)$ on the middle shelf, $15(12.4 \%)$ on the mesobenthal slope, and $14(11.6 \%)$ on the inner shelf (Table 8$)$. It is interesting to note that the percentage of samples in each depth category was similar to the percentage of species with centers of distribution in each depth category (i.e., $38.5 \%$ of the total samples were on the outer shelf, $24.1 \%$ on the middle shelf, $18.4 \%$ on the mesobenthal slope and $15.4 \%$ on the inner shelf (Table 1).

In general, the species within a family differed in distribution pattern (zoogeographic and life zone patterns combined; Table 8). The greatest overlap in distribution patterns occurred in the family Scorpaenidae. Seven species of rockfish (darkblotched rockfish, Sebastes crameri; greenstriped rockfish, S. elongatus; widow rockfish, $S$. entomelas; yellowtail rockfish, S. flavidus; bocaccio, $S$. paucispinis; canary rockfish, $S$. pinniger; and yelloweye rockfish, $S$. ruberrimus) are eastern boreal Pacific, middle shelf-mesobenthal (outer shelf) species. Three pairs of rockfishes (silvergray rockfish, $S$. brevispinis and redstripe rockfish, $S$. proriger; rosethorn rockfish, S. helvomaculatus, and sharpchin rockfish, S. zacentrus; and chilipepper, $S$. goodei, and shortbelly rockfish, $S$. jordani) also have overlapping distribution patterns. In addition to these, sympatric species pairs occurred in the Rajidae (big skate, Raja binoculata, and longnose skate, $R$. rhina), Macrouridae (giant grenadier, Albatrossia pectoralis, and popeye grenadier, Coryphaenoides cinereus), and Pleuronectidae (arrowtooth flounder, Atheresthes stomias, and petrale sole, Eopsetta jordani; slender sole, E. exilis, and rex sole, Errex zachirus). 
Table 6

Zoogeographic classification of common fishes of the Bering Sea and northeastern Pacific.

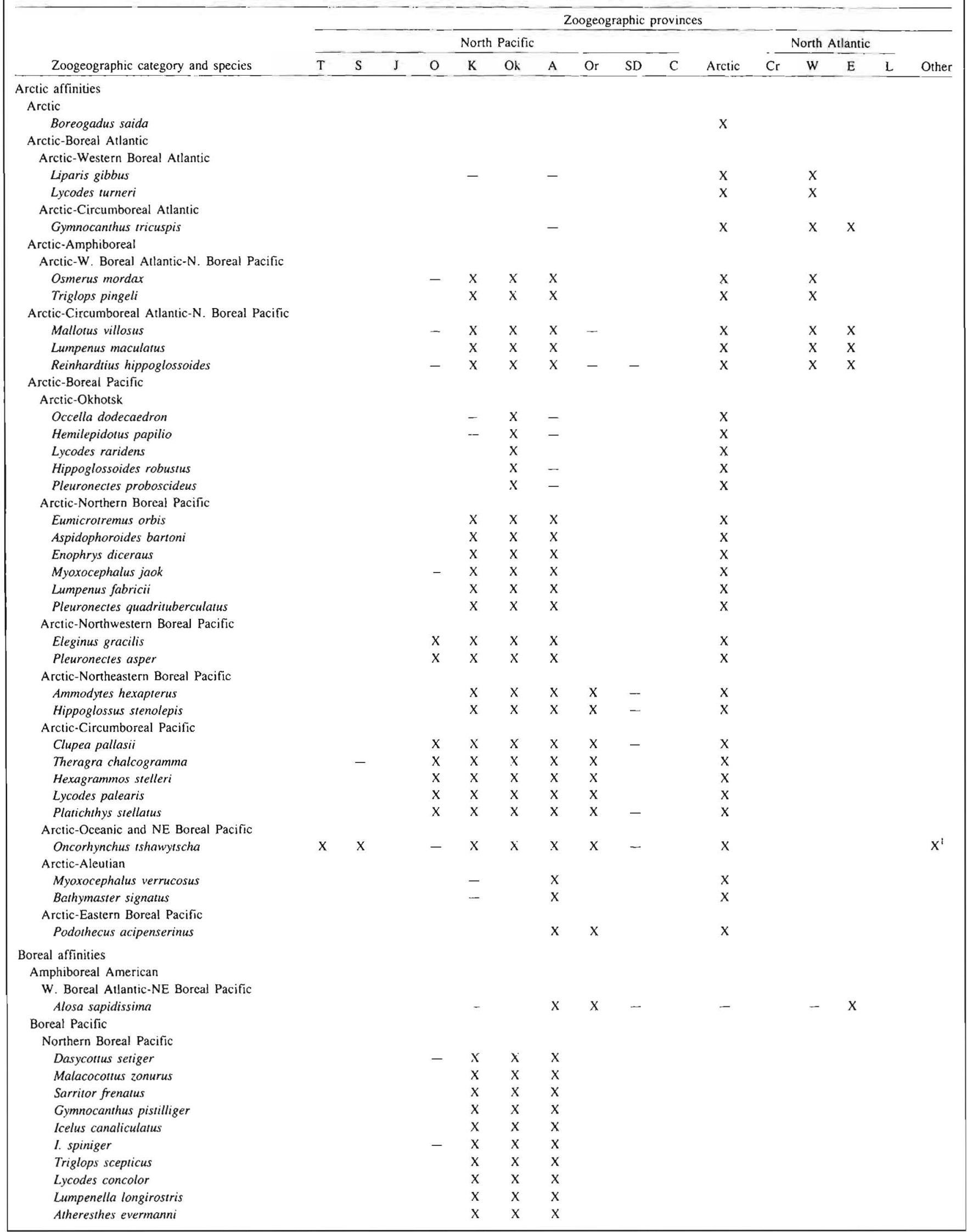




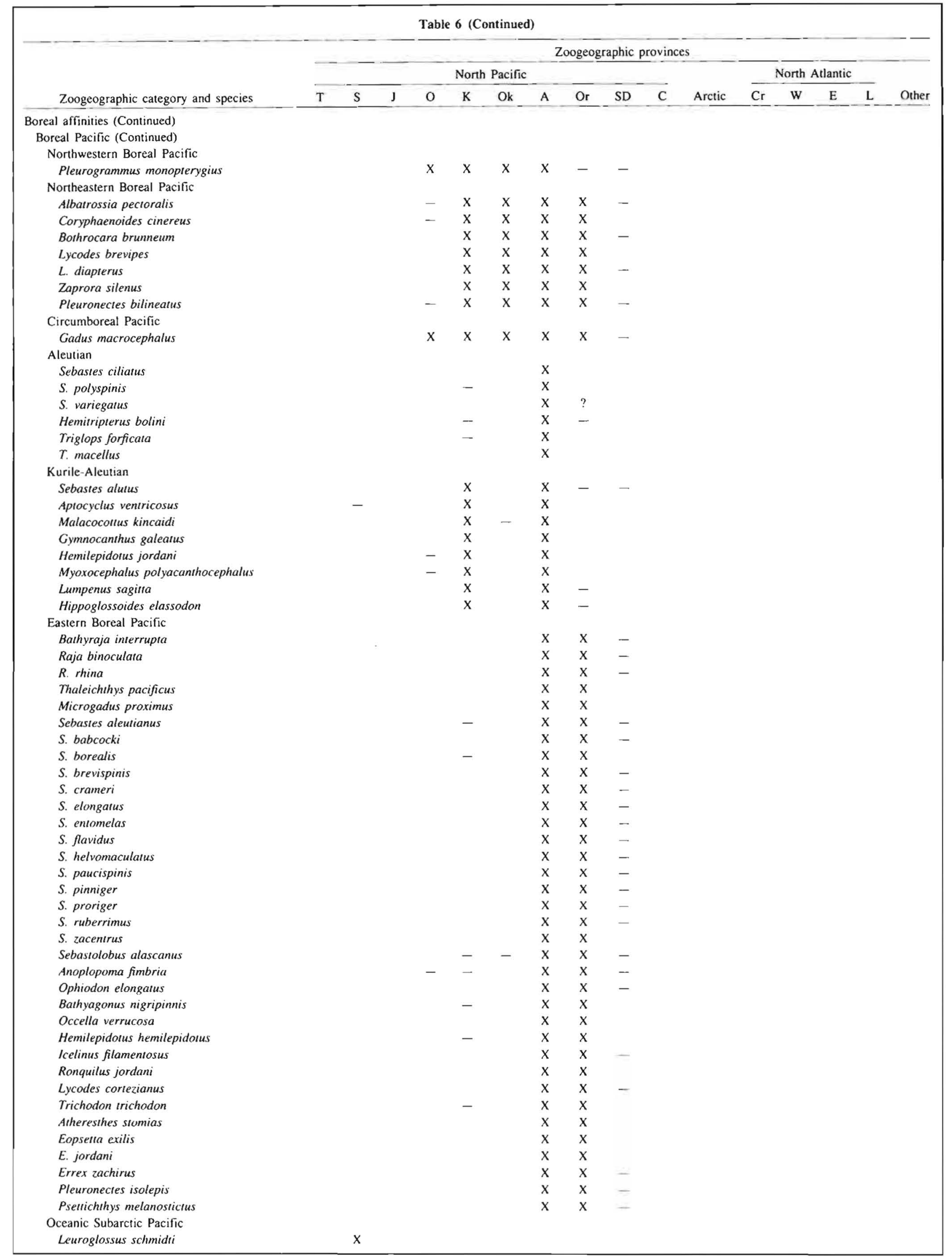


Table 6 (Continued)

Zoogeographic provinces

\begin{tabular}{|c|c|c|c|c|c|c|c|c|c|c|c|c|c|c|c|}
\hline \multicolumn{15}{|c|}{ Zoogeographic provinces } & \\
\hline \multicolumn{10}{|c|}{ North Pacific } & & \multicolumn{4}{|c|}{ North Atlantic } & \\
\hline $\mathrm{T}$ & $s$ & $\mathrm{~J}$ & $\mathrm{O}$ & $\mathrm{K}$ & $\mathrm{Ok}$ & A & Or & SD & $\mathrm{C}$ & Arctic & $\mathrm{Cr}$ & w & $\mathrm{E}$ & $\mathrm{L}$ & Other \\
\hline
\end{tabular}

Boreal affinities (Continued)

Boreal Pacific (Continued)

Oceanic Boreal Pacific

Chauliodus macouni

$\mathrm{X} \quad \mathrm{X}$

Temperate affinities

Antitropical temperate

Squalus acanthias

Temperate North Pacific Antimora microlepis

Eastern Boreal Pacific-San Diegan

Microstomus pacificus

Pleuronectes vetulus

Eastern Temperate Pacific

Sebastes diploproa

Oregonian-San Diegan

Torpedo californica

Merluccius productus

Porichthys notatus

Sebastes aurora

S. goodei

S. jordani

S. melanostomus

S. rubrivinctus

S. saxicola

Citharichthys sordidus

$\begin{array}{llllllll}X & X & X & X & X & X & X\end{array}$

$\begin{array}{lllll}\mathrm{X} & \mathrm{X} & \mathrm{X} & \mathrm{X}^{2}\end{array}$

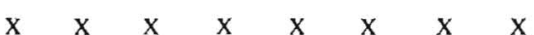

$\mathrm{X}^{3}$

Oregonian-Californian

Hydrolagus colliei

Zalembius rosaceus

$\begin{array}{lll}x & X & x \\ x & x\end{array}$

X $\quad \mathrm{X} \quad \mathrm{X} \quad \mathrm{X}$

Introduced successfully into Aukland and Cookian Provinces of New Zealand.

${ }^{2}$ Also common in Southern Hemisphere in the following provinces: Southwestern Africa; Agulhas;

Southwestern Australian; Tasmanian; Southeastern Australian; Aukland; Cookian; Peru-Chilean; and

Magellan. Occasionally in Eastern South American, Caribbean, West Indian, and Western Indian Ocean.

Possibly in Indo-Polynesian.

${ }^{3} \mathrm{Also}$ along slope of some Indo-Polynesian Islands in North Pacific.

Symbols:

$\mathrm{X}$ Province is major part of range

- Present in province but occurrence is occasional or undetermined

$-x \quad x$

$\mathrm{X}$
$-\mathrm{X}$
$-\mathrm{X}$

- $\mathrm{X}$ X

$X \quad X$

$X \quad X$

- $\mathrm{x} x$

$x \quad x$

$-x \quad x$

? Uncertain

Table 7

Life zone classification of common fishes of the Bering Sea and northeastern Pacific. Life zone designation in parentheses indicates major zone of occurrence.

\begin{tabular}{|c|c|c|c|c|c|c|c|c|c|c|c|c|c|}
\hline \multirow[b]{4}{*}{ Life zone category and species } & \multicolumn{13}{|c|}{ Life zones } \\
\hline & & & \multirow[b]{3}{*}{$\mathrm{N}$} & \multicolumn{3}{|c|}{ Pelagic } & \multicolumn{7}{|c|}{ Benthic } \\
\hline & \multicolumn{2}{|c|}{ Freshwater } & & & Oceanic & & \multirow[b]{2}{*}{ I } & \multicolumn{3}{|c|}{ Sublittoral } & \multicolumn{3}{|c|}{ Bathyal } \\
\hline & $\mathrm{F}$ & $\mathrm{E}$ & & $\mathrm{EP}$ & MP & $\mathrm{BP}$ & & IS & MS & OS & MB & $\mathrm{BB}$ & $A B$ \\
\hline \multicolumn{14}{|l|}{ Pelagic species } \\
\hline \multicolumn{14}{|l|}{ Fluvial-Neritic (Neritic) } \\
\hline Osmerus mordax & $\mathrm{X}$ & $\mathrm{X}$ & $\mathbf{M}$ & - & $?$ & & & & & & & & \\
\hline \multicolumn{14}{|l|}{ Fluvial-Oceanic (Neritic) } \\
\hline Alosa sapidissima & $\mathrm{X}$ & $\mathrm{X}$ & M & $\mathrm{X}$ & $?$ & & & & & & & & \\
\hline Thaleichthys pacificus & $\mathrm{X}$ & $\mathrm{X}$ & $\mathbf{M}$ & $\mathrm{X}$ & $?$ & & & & & & & & \\
\hline Oncorhynchus tshawytscha & $\mathrm{X}$ & $\mathrm{x}$ & $\mathbf{M}$ & $\mathrm{X}$ & $?$ & & & & & & & & \\
\hline \multicolumn{14}{|l|}{ Estuarine-Epipelagic (Neritic) } \\
\hline Clupea pallasii & & $\mathrm{X}$ & $M$ & $\mathrm{X}$ & $?$ & & & & & & & & \\
\hline \multicolumn{14}{|l|}{ Neritic-Epipelagic (Neritic) } \\
\hline Mallotus villosus & & & M & $\mathrm{x}$ & $?$ & & & & & & & & \\
\hline Boreogadus saida & - & - & $\mathrm{M}$ & $\mathrm{X}$ & $?$ & & & & & & & & \\
\hline \multicolumn{14}{|l|}{ Neritic-Mesopelagic (Neritic) } \\
\hline Merluccius productus & & & $\mathbf{M}$ & $\mathrm{X}$ & $\mathrm{X}$ & & & & & & & & \\
\hline Theragra chalcogramma & & & $\mathrm{M}$ & $\mathrm{X}$ & $\mathrm{X}$ & & & & & & & & \\
\hline Aptocyclus ventricosus & & & M & $\mathrm{x}$ & $\mathrm{x}$ & $?$ & & & & & & & \\
\hline \multicolumn{14}{|l|}{ Mesopelagic (Mesopelagic) } \\
\hline Leuroglossus schmidti & & & & - & M & - & & & & & & & \\
\hline Chauliodus macouni & & & & - & M & - & & & & & & & \\
\hline
\end{tabular}




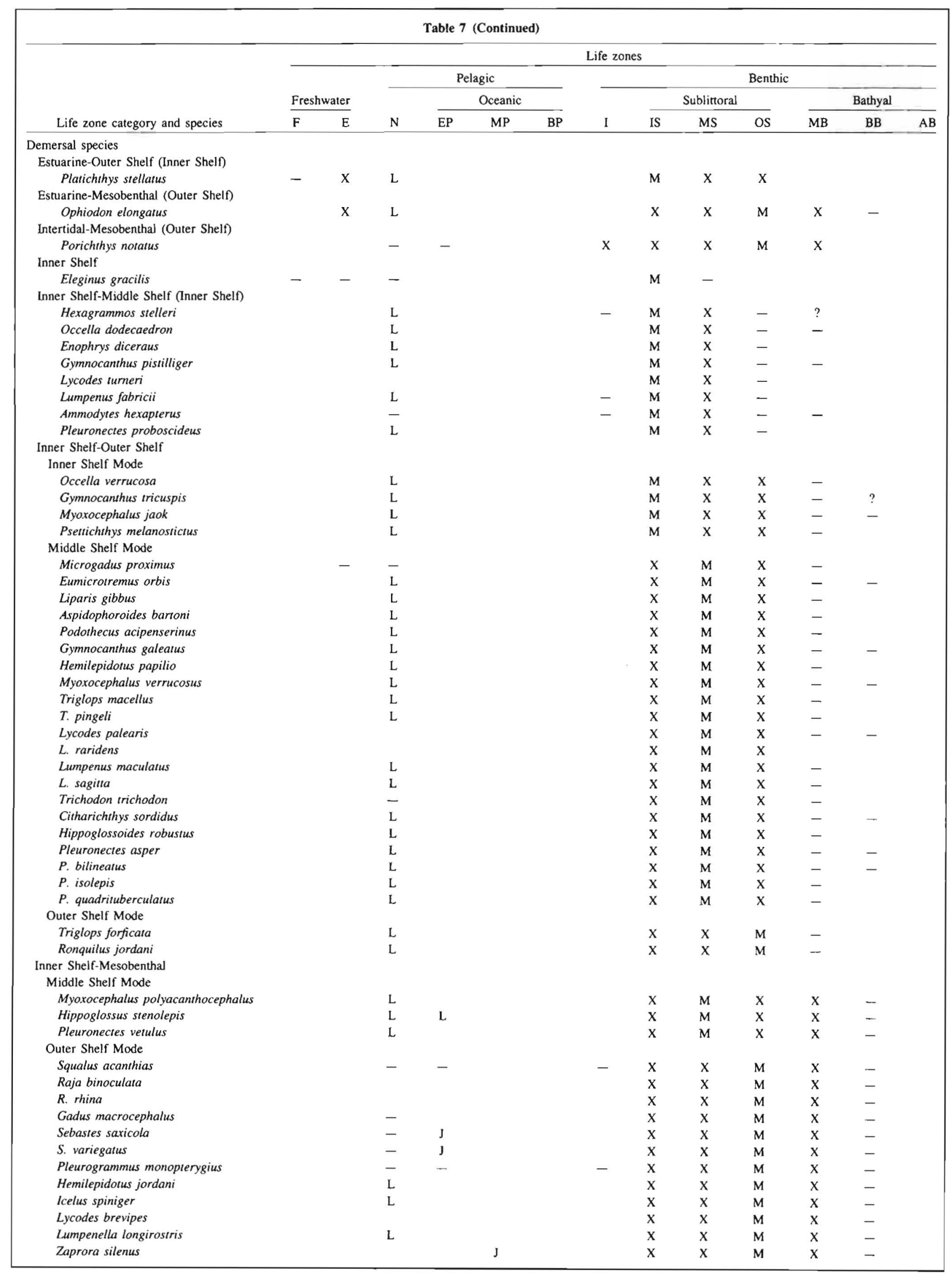




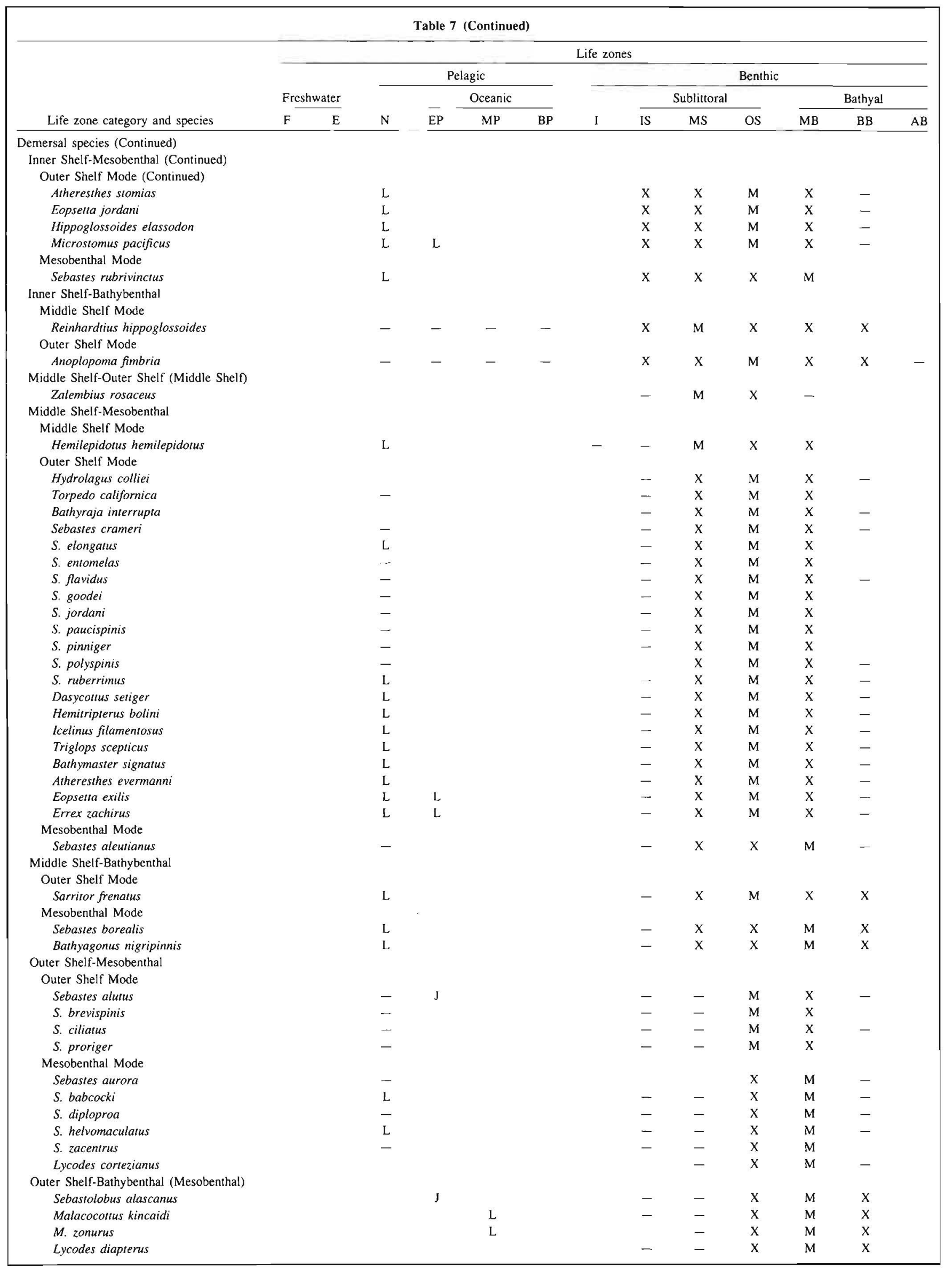




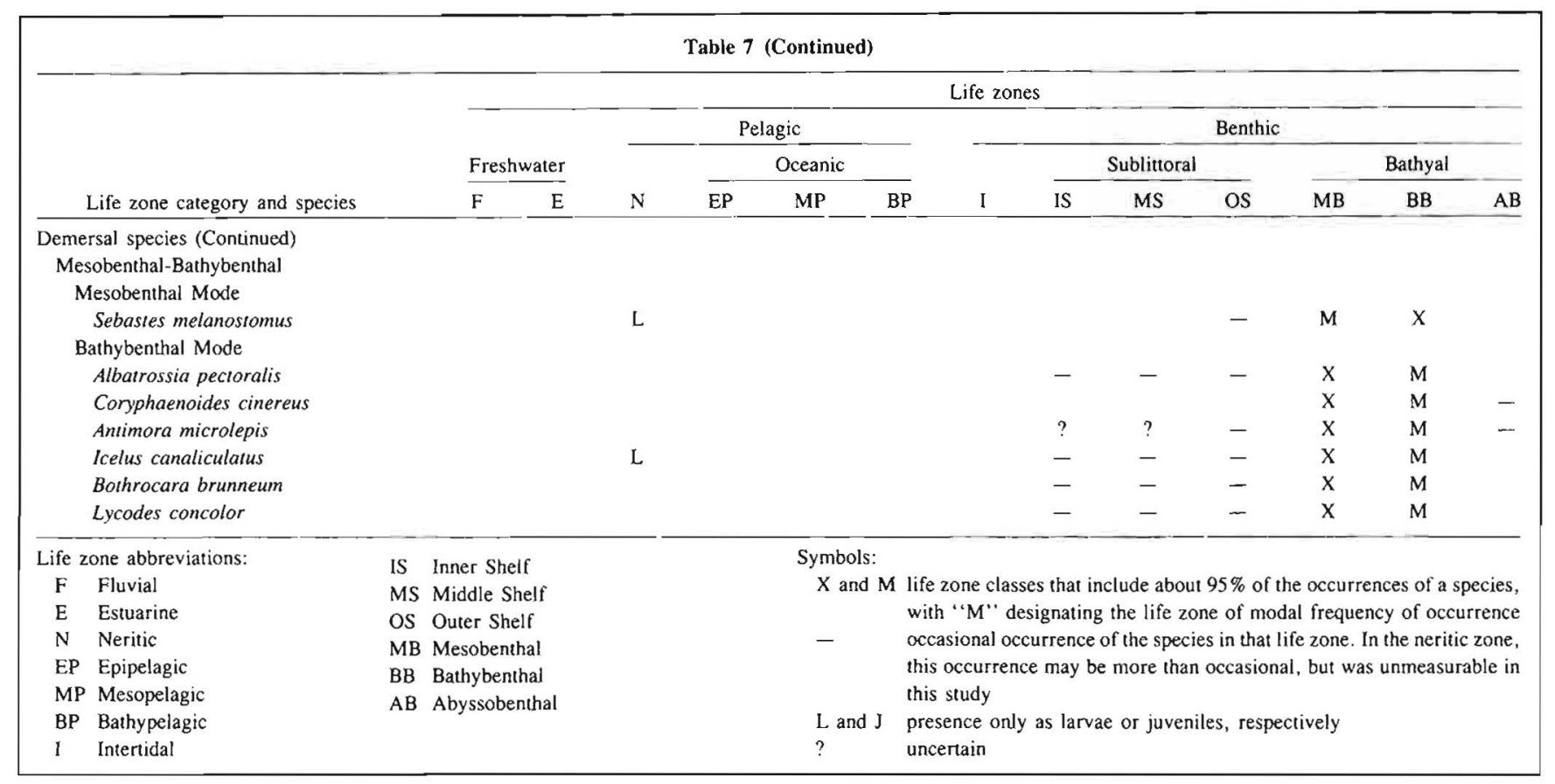

Table 8

Summary of zoogeographic and life zone classifications for common fish species in the Bering Sea and northeastern Pacific.

\begin{tabular}{|c|c|c|c|}
\hline \multirow[b]{2}{*}{ Species } & \multirow[b]{2}{*}{ Zoogeographic designation } & \multicolumn{2}{|c|}{ Life zone designation } \\
\hline & & Depeh range & Depth mode \\
\hline \multicolumn{4}{|l|}{ Class Chondrichthyes } \\
\hline \multirow{2}{*}{\multicolumn{4}{|c|}{$\begin{array}{l}\text { Order Chimaeriformes } \\
\text { Chimaeridae }\end{array}$}} \\
\hline & & \multicolumn{2}{|c|}{ Chimaeridae } \\
\hline Hydrolagus colliei & Oregonian-Californian & Middle Shelf-Mesobenthal & Outer Shelf \\
\hline \multicolumn{4}{|l|}{ Order Squaliformes } \\
\hline \multicolumn{4}{|l|}{ Squalidae } \\
\hline Squalus acanthias & Antitropical Temperate & Inner Shelf-Mesobenthal & Outer Shelf \\
\hline \multicolumn{4}{|l|}{ Order Rajiformes } \\
\hline \multicolumn{4}{|l|}{ Torpedinidae } \\
\hline Torpedo californica & Oregonian-San Diegan & Middle Shelf-Mesobenthal & Outer Shelf \\
\hline \multicolumn{4}{|l|}{ Rajidae } \\
\hline Bathyraja interrupta & Eastern Boreal Pacific & Middle Shelf-Mesobenthal & Outer Shelf \\
\hline Raja binoculata & Eastern Boreal Pacific & Inner Shelf-Mesobenthal & Outer Shelf \\
\hline R. rhina & Eastern Boreal Pacific & Inner Shelf-Mesobenthal & Outer Shelf \\
\hline \multicolumn{4}{|l|}{ Class Osteichthyes } \\
\hline \multicolumn{4}{|l|}{ Order Clupeiformes } \\
\hline \multicolumn{4}{|l|}{ Clupeidae } \\
\hline Alosa sapidissima & Amphiboreal American (WBA-NEBP) & Fluvial-Oceanic (EM) & Neritic \\
\hline Clupea pallasii & Arctic-Circumboreal Pacific & Estuarine-Epipelagic & Neritic \\
\hline \multicolumn{4}{|l|}{ Order Salmoniformes } \\
\hline \multicolumn{4}{|l|}{ Bathylagidae } \\
\hline Leuroglossus schmidti & Oceanic Subarctic Pacific & Mesopelagic & Mesopelagic \\
\hline \multicolumn{4}{|l|}{ Osmeridae } \\
\hline Mallotus villosus & Arctic-Amphiboreal (CBA-NBP) & Neritic-Epipelagic & Neritic \\
\hline Osmerus mordax & Arctic-Amphiboreal (WBA-NBP) & Fluvial-Neritic & Neritic \\
\hline Thaleichthys pacificus & Eastern Boreal Pacific & Fluvial-Oceanic (EM) & Neritic \\
\hline \multicolumn{4}{|l|}{ Salmonidae } \\
\hline Oncorhynchus tshawytscha & Arctic-Oceanic and NE Boreal Pacific & Fluvial-Oceanic (EM) & Neritic \\
\hline \multicolumn{4}{|l|}{ Order Stomifformes } \\
\hline \multicolumn{4}{|l|}{ Chauliodontidae } \\
\hline Chauliodus macouni & Oceanic Boreal Pacific & Mesopelagic & Mesopelagic \\
\hline \multicolumn{4}{|l|}{ Order Gadiformes } \\
\hline \multicolumn{4}{|l|}{ Macrouridae } \\
\hline Albatrossia pecioralis & Northeastern Boreal Pacific & Mesobenthal-Bathybenthal & Bathybenthal \\
\hline Coryphaenoides cinereus & Northeastern Boreal Pacific & Mesobenthal-Bathybenthal & Bathybenthal \\
\hline \multicolumn{4}{|l|}{ Merlucciidae } \\
\hline Merluccius productus & Oregonian-San Diegan & Neritic-Mesopelagic & Neritic \\
\hline
\end{tabular}




\begin{tabular}{|c|c|c|c|}
\hline \multicolumn{4}{|c|}{ Table 8 (Continued) } \\
\hline \multirow[b]{2}{*}{ Species } & \multirow[b]{2}{*}{ Zoogeographic designation } & \multicolumn{2}{|c|}{ Life zone designation } \\
\hline & & Depth range & Depth mode \\
\hline \multicolumn{4}{|l|}{ Class Osteichthyes (Continued) } \\
\hline \multicolumn{4}{|l|}{ Order Gadiformes (Continued) } \\
\hline \multicolumn{4}{|l|}{ Gadidae } \\
\hline Boreogadus saida & Arctic & Neritic-Epipelagic & Neritic \\
\hline Eleginus gracilis & Arctic-Northwestern Boreal Pacific & Inner Shelf & Inner Shelf \\
\hline Gadus macrocephalus & Circumboreal Pacific & Inner Shelf-Mesobenthal & Outer Shelf \\
\hline Microgadus proximus & Eastern Boreal Pacific & Inner Shelf-Outer Shelf & Middle Shelf \\
\hline Theragra chalcogramma & Arctic-Circumboreal Pacific & Neritic-Mesopelagic & Neritic \\
\hline \multicolumn{4}{|l|}{ Moridae } \\
\hline Antimora microlepis & Temperate Norh Pacific & Mesobenthal-Bathybenthal & Bathybenthal \\
\hline \multicolumn{4}{|l|}{ Order Batrachoidiformes } \\
\hline \multicolumn{4}{|l|}{ Batrachoididae } \\
\hline Porichthys notatus & Oregonian-San Diegan & Intertidal-Mesobenthal & Outer Shelf \\
\hline \multicolumn{4}{|l|}{ Order Scorpaeniformes } \\
\hline Scorpaenidae & & & \\
\hline Sebastes aleutianus & Eastern Boreal Pacific & Middle Shelf-Mesobenthal & Mesobenthal \\
\hline S. alutus & Kurile-Aleutian & Outer Shelf-Mesobentha' & Outer Shelf \\
\hline S. aurora & Oregonian-San Diegan & Outer Sheif-Mesobenthal & Mesobenthal \\
\hline S. babcocki & Eastern Boreal Pacific & Outer Shelf-Mesobenthal & Mesobenthal \\
\hline S. borealis & Eastern Boreal Pacific & Middle Shelf-Bathybenthal & Mesobenthal \\
\hline S. brevispinis & Eastern Boreal Pacific & Outer Shelf-Mesobenthal & Outer Shelf \\
\hline S. ciliatus & Aleutian & Outer Shelf-Mesobenthal & Outer Shelf \\
\hline S. crameri & Eastern Boreal Pacific & Middle Shelf-Mesobenthal & Outer Shelf \\
\hline S. diploproa & Eastem Temperate Pacific & Outer Shelf-Mesobenthal & Mesobenthal \\
\hline S. elongatus & Eastern Boreal Pacific & Middle Shelf-Mesobenthal & Outer Shelf \\
\hline S. entomelas & Eastem Boreal Pacific & Middle Shelf-Mesobenthal & Outer Shelf \\
\hline S. flavidus & Eastern Boreal Pacific & Middle Shelf-Mesobenthal & Outer Shelf \\
\hline S. goodei & Oregonian-San Diegan & Middle Shelf-Mesobenthal & Outer Shelf \\
\hline S. helvomaculatus & Eastern Boreal Pacific & Outer Shelf-Mesobenthal & Mesobenthal \\
\hline S. jordani & Oregonian-San Diegan & Middle Shelf-Mesobenthal & Outer Shelf \\
\hline$S$. melanostomus & Oregonian-San Diegan & Mesobenthal-Bathybenthal & Mesobenthal \\
\hline S. paucispinis & Eastern Boreal Pacific & Middle Shelf-Mesobenthal & Outer Shelf \\
\hline S. pinniger & Eastern Boreal Pacific & Middle Shelf-Mesobenthal & Outer Shelf \\
\hline S. polyspinis & Aleutian & Middle Shelf-Mesobenthal & Outer Shelf \\
\hline S. proriger & Eastern Boreal Pacific & Outer Shelf-Mesobenthal & Outer Shelf \\
\hline S. ruberrimus & Eastern Boreal Pacific & Middle Shelf-Mesobenthal & Outer Shelf \\
\hline S. rubrivinctus & Oregonian (M)-San Diegan & Inner Shelf-Mesobenthal & Mesobenthal \\
\hline S. saxicola & Oregonian-San Diegan & Inner Shelf-Mesobenthal & Outer Shelf \\
\hline S. variegatus & Aleutian & Inner Shelf-Mesobenthal & Outer Shelf \\
\hline S. zacentrus & Eastern Boreal Pacific & Outer Shelf-Mesobenthal & Mesobenthal \\
\hline Sebastolobus alascanus & Eastern Boreal Pacific & Outer Shelf-Bathybenthal & Mesobenthal \\
\hline Anoplopomatidae & & & \\
\hline Anoplopoma fimbria & Eastern Boreal Pacific & Inner Shelf-Bathybenthal & Outer Shelf \\
\hline Hexagrammidae & & & \\
\hline Hexagrammos stelleri & Arctic-Circumboreal Pacific & Inner Shelf-Middle Shelf & Inner Shelf \\
\hline Ophiodon elongatus & Eastern Boreal Pacific & Estuarine-Mesobenthal & Outer Shelf \\
\hline Pleurogrammus monopterygius & Northwestern Boreal Pacific & Inner Shelf-Mesobenthal & Outer Shelf \\
\hline Cyclopteridae & & & \\
\hline Aptocyclus ventricosus & Kurile-Aleutian & Neritic-Mesopelagic & Neritic \\
\hline Eumicrotremus orbis & Arctic-Northern Boreal Pacific & Inner Shelf-Outer Shelf & Middle Shelf \\
\hline Liparis gibbus & Arctic-Westem Boreal Atlantic & Inner Shelf-Outer Shelf & Middle Shelf \\
\hline Psychrolutidae & & & \\
\hline Dasyconus setiger & Northern Boreal Pacific & Middle Shelf-Mesobenthal & Outer Shelf \\
\hline Malacocottus kincaidi & Kurile-Aleutian & Outer Shelf-Bathybenthal & Mesobenthal \\
\hline M. zonurus & Northern Boreal Pacific & Outer Shelf-Bathybenthal & Mesobenthal \\
\hline Agonidae & & & \\
\hline Aspidophoroides bartoni & Arctic-Northern Boreal Pacific & Inner Shelf-Outer Shelf & Middle Shelf \\
\hline Bathyagonus nigripinnis & Eastern Boreal Pacific & Middle Shelf-Bathybenthal & Mesobenthal \\
\hline Occella dodecaedron & Arctic-Okhotsk & Inner Shelf-Middle Shelf & Inner Shelf \\
\hline o. verrucosa & Eastern Boreal Pacific & Inner Shelf-Outer Shelf & Inner Shelf \\
\hline Podothecus acipenserinus & Arctic-Eastern Boreal Pacific & Inner Shelf-Outer Shelf & Middle Shelf \\
\hline Sarritor frenatus & Northern Boreal Pacific & Middle Shelf-Bathybenthal & Outer Shelf \\
\hline Hemitripteridae & & & \\
\hline Hemitripterus bolini & Aleutian & Middle Shelf-Mesobenthal & Outer Shelf \\
\hline Contidae & & & \\
\hline Enophrys diceraus & Arctic-Northern Boreal Pacific & Inner Shelf-Middle Shelf & Inner Shelf \\
\hline Gymnocanthus galeatus & Kurile-Aleutian & Inner Shelf-Outer Shelf & Middle Shelf \\
\hline G. pistilliger & Northern Boreal Pacific & Inner Shelf-Middle Shelf & Inner Shelf \\
\hline G. tricuspis & Arctic-Circumboreal Atlantic & Inner Shelf-Outer Shelf & Inner Shelf \\
\hline Hemilepidotus hemilepidotus & Eastern Boreal Pacific & Middle Shelf-Mesobenthal & Middle Shelf \\
\hline
\end{tabular}




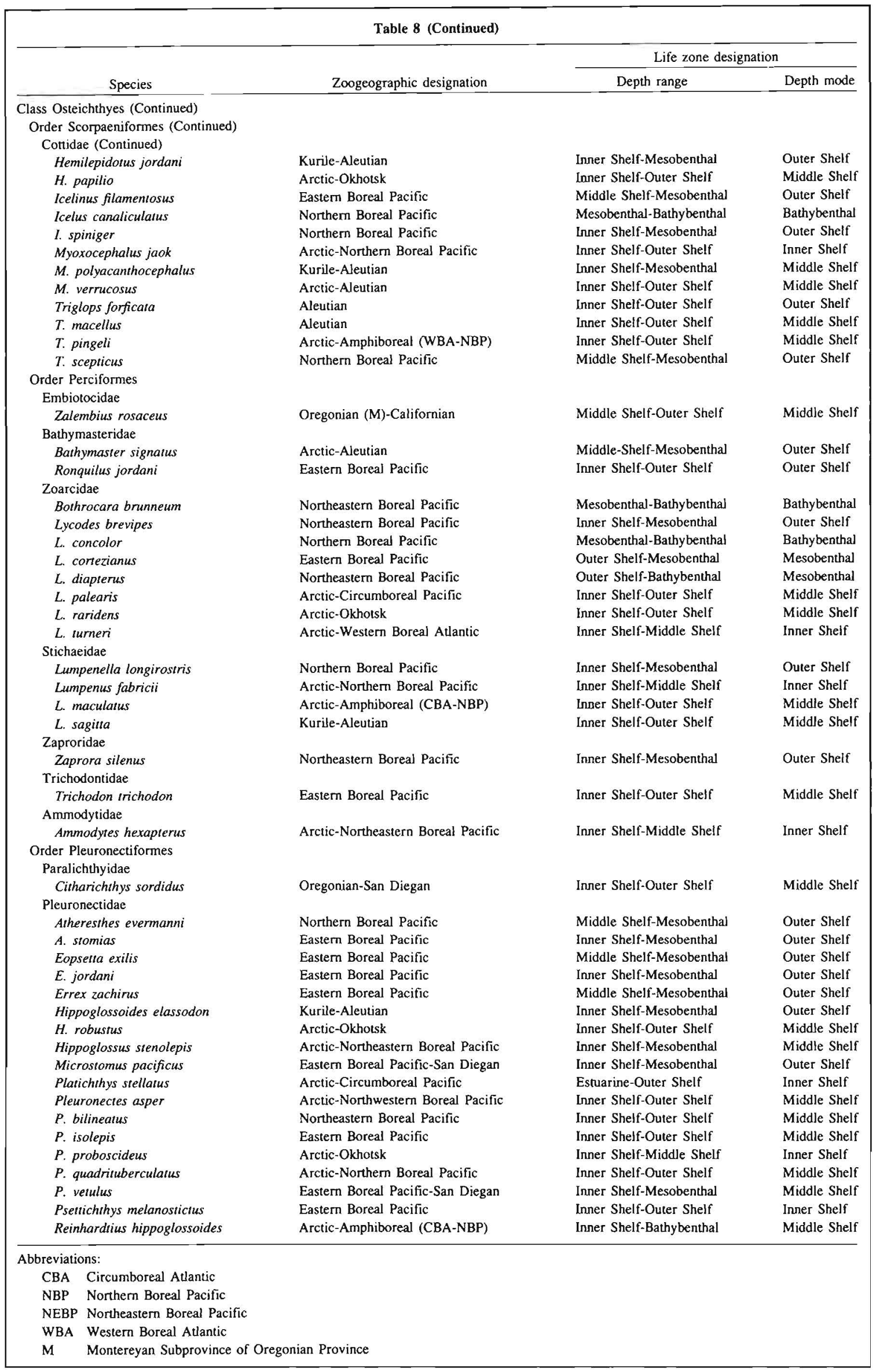




\section{DISCUSSION}

Although the species examined in this study were unequally distributed among zoogeographic range types, life zones, and depth zones, this distribution pattern is largely the result of the distribution of sampling effort. Because the greatest sampling effort was in the eastern boreal Pacific, the greatest number of species examined were eastern boreal Pacific species. The Arctic region was sampled more frequently than the warm temperate regions south of Point Conception, California, and this is reflected in the greater number of species with Arctic rather than temperate distributions. Further, because demersal trawls were the major sampling device used, most species had benthic affinities. As noted above, the percentage of total species with centers of distribution in a given depth zone roughly corresponded to the percentage of total samples in that depth zone. Thus, care should be taken in using the summary of distribution patterns as a description of general zoogeographic or life zone patterns found among species in the area.

In addition to sampling bias, this study is also biased in terms of the species chosen for examination. Only frequently occurring species (i.e., occurring in 100 or more samples) were examined. Hence, wide-ranging species were generally selected and species with limited ranges were seldom included. Zoogeographic provinces, however, are defined largely on the distribution of shortrange species. Briggs (1974) defined provinces based on $10 \%$ or more endemism for a region; in other words, regions where $10 \%$ or more of the species had similar limited ranges. These endemic species were largely from invertebrate rather than fish taxa. Because the major emphasis of the present study is to show the distribution patterns of the most common fish species found in the database (and, hence, demersally along the west coast of boreal North America), our analyses of wide-ranging species are appropriate. However, the database also has information on limited-range species (although some of these are merely widely-distributed species that were ineffectively sampled by the methods used). Further studies on the west coast fauna should examine distributional information on these species found in the database.

In addition, although the classification of the distribution patterns of limited-range species is simple (if their range corresponds to that of a province), the classification of long-range species is not so easy. There is no terminology that is consistently used in the literature. Andriyashev (1939) classified many Bering Sea species by range, but included a subarctic region in many names. Briggs (1974), however, did not define a subarctic region for any region in the world, limiting the names of the regions at subarctic latitudes to Arctic or cold temperate (boreal). Hedgpeth (1957b) defined an Arctic region for the Sea of Okhotsk and part of the western Bering Sea. In the present study, seven species show distribution patterns that include both the Sea of Okhotsk and the colder portions of the Bering Sea shelf north to the Chukchi Sea. These species were classified as Arctic-northern boreal Pacific (Okhotsk), using provinces defined in Briggs (1974). However, this pattern may best represent a subarctic Pacific region. Both the Sea of Okhotsk and the eastern Bering Sea are covered with ice during a large part of the year, but are ice-free for the rest of the year. The species with this pattern do not extend far into the Arctic nor do they occur very far into other northern boreal provinces. If the $10 \%$ endemism rule is used to define provinces, more Sea of Okhotsk species should be examined for this distribution pattern. It may well be that the Okhotsk province of Briggs (1974) should include the northern shelf of the eastern Bering Sea and should be termed Subarctic Pacific rather than Okhotsk.
Briggs (1974) noted that the distribution patterns of organisms in the Bering Sea were not well known and defined the Arctic region as extending south to Nunivak Island and Cape Olyutorski (based largely on the southerly extent of sea ice during the winter). Andriyashev (1939) analyzed the species of the Bering Sea quite thoroughly with respect to their zoogeographical relationships and showed that this region was an overlap zone (or ecotone) for at least three zoogeographic provinces. These include (in the terminology of Briggs, 1974) the Arctic, eastern boreal Pacific, and western boreal Pacific regions. The region of overlap between the westem boreal Pacific and Arctic regions in the northern Bering Sea was considered to be a subarctic region. The map of the distribution of these provinces in the Bering Sea shown in Andriyashev (1939) is essentially correct (based on an examination of the ranges of species in the present study). It includes a tongue of the Aleutian Province along the slope of the Bering Sea to Navarin Canyon. However, based on information in the present study, subarctic and Arctic species appear to extend further southeast along the middle shelf zone. This region corresponds to a cold-water hydrographic domain noted by Kinder and Schumacher (1981) and others.

Because the present study does not include all species of the fauna, we will not attempt to examine province boundaries. However, it is apparent that many species in the eastern Bering Sea (with primarily western boreal or Arctic affinities) extend east to about Kodiak Island. Many species that were once thought to reach southeast Alaska were later found (in the literature) farther south to Vancouver Island or Puget Sound, and other species that were thought to extend north to southeastern Alaska have now been found (in maps in this study) as far west as Kodiak Island or the Alaska Peninsula. Peden and Wilson (1976) noted that the boundary between the Aleutian and Oregonian Provinces apparently does not occur at Dixon Entrance (as suggested by Briggs 1974). Preliminary analyses of the relative abundance of some geographically-displacing species (based on data at the Northwest and Alaska Fisheries Center) suggest that the boundary between these provinces occurs off northern Vancouver Island. Further study on the distribution of fishes in the Gulf of Alaska is needed (particularly between southeast Alaska and Puget Sound) to resolve this problem.

Only two species, the flag rockfish, Sebastes rubrivinctus, and pink seaperch, Zalembius rosaceus, appeared, at least partially, to confirm the presence of a Montereyan Subprovince of the Oregonian Province, as defined by Hubbs (1974). More extensive sampling in the south may have increased the frequency of occurrence of species with this distribution pattern in the database. It does appear, however, that Cape Mendocino, California, is an important southern limit (at least in abundance) of many northern species.

Although there were many range extensions from the database, few species taken at the range edges were ever collected and deposited in fish collections. Hence, each extension is somewhat uncertain and we have tried to identify those that are less reasonable from those that are probably real extensions. It is hoped that in the future, specimens will be collected from the edges of the ranges of each species for deposition in an established fish collection. This is particularly important for those species which may have been confused with other species in the field.

The domination of the survey by wide-ranging species is also apparent in the classification of species by life zone. Sublittoral-bathyal species were most numerous, but most of these extended from the inner or middle shelf to the mesobenthal slope. The dominance of sublittoral (inner shelf-outer shelf) species when specific life zone spans are considered confirms the validity of a distinct shelf fauna. The paucity of samples in inshore, bathybenthal, neritic, and oceanic 
areas does not allow for an adequate evaluation of these zones. Although species with distributions limited to inshore areas occur in this survey, species restricted to the mesobenthal environment did not occur.

This study differs from that of Fedorov (1973a), which classified Bering Sea fishes by life zone, in that species were categorized by the range of life zones which contain $95 \%$ of the occurrences rather than by a more subjective placement of species into single life zones. That study, however, gave a more complete description of the species found in a life zone because all species found in the Bering Sea were considered. Allen (1982) defined possible life zone boundaries on the southern California shelf by noting depths at which a high percentage of foraging guilds of fishes showed shifts in species dominance. Thus, of 18 guilds of soft-bottom fishes, the dominant species of a guild shifted from one species to another in $50 \%$ of the guilds at $80 \mathrm{~m}$, in $44 \%$ at $170 \mathrm{~m}$, and in $39 \%$ at $20 \mathrm{~m}$. This study emphasized using the shifts in relative abundance of ecologically-similar species for defining faunal boundaries rather than just considering the frequency distribution with regard to depth of single species.

Additional work needs to be done to define faunal boundaries between zoogeographic provinces or life zones. Because the abundance of a species often decreases almost asymptotically near the edges of the range, the endpoints of a species range often occur far outside its area of abundance. Hence, faunal studies should be concerned with defining the ranges of species in terms of areas of abundance rather than of total range. Until recently, however, summarization of the within-range distribution of species has been difficult and time consuming. If occurrence patterns are known, then the distribution can be described in terms of the area containing $95 \%$ (or some other percentage) of the occurrences. Faunal regions can then be described as areas containing the common occurrence of large numbers of limited-range species. When assigning species to zoogeographic and life zone patterns, it is preferable to use the region of common occurrence rather than that of modal occurrence. The former accounts for the importance of wide-ranging species in more than one faunal category, while this is obviously obscured in the latter. In addition to using the distribution patterns of individual species removed from the context of their communities, a description of the distribution patterns of species (particularly of ecological counterparts) in large-scale communities or assemblages might prove to be valuable for determining faunal boundaries and for assigning species to faunal categories.

Although the intent of this paper was to make use of a large set of data on the distribution of Bering Sea and northeastern Pacific fishes and of computer summarization and mapping techniques to better describe the zoogeographic patterns of fishes, it falls short of this goal in several ways. Because the entire range of many species was not included in the database, much of the zoogeographic speculation is based on literature records. This study, however, does provide a better description of the distribution patterns of species in the Bering Sea, the only area with a sufficiently broad shelf to detail within-shelf distribution patterns of species at the geographic scale of consideration. Because the frequency of occurrence of species within their geographic ranges has not been adequately described, regions of common occurrence still remain to be described. In addition, because of the focus on common species rather than on the entire fauna, the location of previously described faunal boundaries cannot be adequately evaluated. The description of the distribution with regard to depth helps to better define the depth range of species, but the frequency distributions were based on the percentage of the total occurrences of a species within a depth interval rather than the percentage of total samples within a depth interval. Both approaches are affected by total sampling effort but the latter is likely to give misrepresentative modes in intervals with low sampling effort. Because the entire fauna was not included, no attempt was made to better define life zone boundaries. In spite of these problems it is hoped that the study provides useful information on the distribution of common fish species in the region and will stimulate further investigations to better describe the faunal patterns of Bering Sea and northeastern Pacific fishes.

\section{CONCLUSIONS}

1. Of 121 species of fishes commonly taken by demersal trawls in the Bering Sea and northeastern Pacific, most were boreal species; eastern boreal Pacific species were most numerous, followed by northern boreal Pacific and Kurile-Aleutian species.

2. Most species examined were sublittoral-bathyal in life zone distribution, followed by sublittoral and bathyal species; however, with regard to more specific life zone designations, sublittoral (inner shelf-outer shelf) species were most numerous followed by middle shelf-mesobenthal and inner shelfmesobenthal species.

3. Most families included species that differed in distribution (combined zoogeographic and life zone) patterns; the greatest number (7) of species with similar distribution patterns occurred among rockfishes (Scorpaenidae).

4. The survey data from 24,881 trawl and fish trap samples collected during a 30-year period extended the known range of 111 commonly occurring species; most of the geographic range extensions were to the north or in the Aleutian Islands, whereas most depth range extensions were of maximum depth.

5. Faunal patterns on the Bering Sea shelf depart from the typical bathymetric pattern of narrow shelf regions because of unusual thermal patterns found in that area.

\section{ACKNOWLEDGMENTS}

We wish to express our gratitude to colleagues at the Northwest and Alaska Fisheries Center who made this study possible and made significant contributions to its presentation. Gary Walters developed the methods for selecting data, map plots, and assisted in many of the data processing steps. Gina Oda did most of the actual data base retrievals, data analyses, and mapping. James Peacock helped prepare the final graphics materials. This research was supported in part (via the senior author) by the National Research Council Research Associateship Program. 


\section{CITATIONS}

ABLE, K. W., and D. E. MCALLISTER.

1980. Revision of the snailfish genus Liparis, from Arctic Canada. Can. Bull. Fish. Aquat. Sci. 208, 52 p.

AHLSTROM, E. H., K. AMAOKA, D. A. HENSLEY, H. G. MOSER, and B. Y. SUMIDA.

1984a. Pleuronectiformes: Development. In Moser, H. G. (chief editor), Ontogeny and systematics of fishes, p. 640-670. Allen Press Inc., Lawrence, KS.

AHLSTROM, E. H., H. G. MOSER, and D. M. COHEN.

1984b. Argentinoidei: Development and relationships. In Moser, H. G. (editor), Ontogeny and systematics of fishes, p. 155-169. Allen Press Inc., Lawrence, KS.

ALLEN, M. J.

1982. Functional structure of the soft-bottom fish communities of the southern California shelf. Ph.D. Thesis, Univ. Calif., San Diego, 577 p. (avail. Univ. Microfilms Internat., Ann Arbor, MI 48106).

ALLEN, M. J., and A. J. MEARNS.

1976. Life history of the Dover sole. South. Calif. Coastal Water Res. Proj. Annu. Rep., p. 223-228. Long Beach, CA 90806.

ALTON, M. S., and T. M. SAMPLE.

1976. Rock sole (family Pleuronectidae). In Pereyra, W. T., J. T. Reeves, and R. G. Bakkala (editors), Demersal fish and shellfish resources of the eastern Bering Sea in the baseline year 1975, p. 461-474. Processed Rep., Northwest and Alaska Fish. Cent., Natl. Mar. Fish. Serv., NOAA, Seattle, WA 98112. ANDRIYASHEV, A. P.

1939. Ocherk zoogeografii i proiskhozhdeniia fauny ryb Beringova moria i sopredelbnykh vod (An outline of the zoogeography and origin of the fish fauna of the Bering Sea and neighboring waters). Lzd. Leningr. Gos. Univ., Leningrad, 187 p. [In Russ.] (Transl. by A. Merrivale, avail. Northwest and Alaska Fish. Cent., Seattle, WA 98112.)

1954. Ryby severnykh morei SSSR (Fishes of the northern seas of the U.S.S.R.). Akad. Nauk SSSR, Opredeliteli po Faune SSSR 53, 566 p. Izd. Akad. Nauk SSSR, Moscow-Leningrad. [In Russ.] (Transl. by Israel Program Sci. Transl., 1964, 617 p., avail. U.S. Dep. Commer., Natl. Tech. Inf. Serv., Springfield, $\mathrm{VA}$, as OTS 63-11160.)

BARSUKOV, V. V

1970. Species composition of genus Sebastes in the North Pacific and description of a new species. Dokl. Biol. Sci. (Engl. transl. Dokl. Akad. Nauk SSSR) 195(1-6):760-763.

BASS, A. J., J. D. D'AUBREY, and N. KISTNASAMY

1976. Sharks of the east coast of southern Africa. VI. The families Oxynotidae, Squalidae, Dalatiidae, and Echinorhinidae. Ocean. Res. Inst. (Durban) Invest. Rep. 45, 103 p.

BAXTER, R.

1985. Annotated key to the fishes of Alaska. Unpubl. manuscr., 325 p. Box 96, Bethel, AK 99559.

BIGELOW, H. B., and W. C. SCHROEDER

1957. A study of the sharks of the suborder Squaloidea. Bull. Mus. Comp. Zool. Harv. Univ. 117(1):1-150.

BORODULINA, O. D

1968. Taxonomy and distribution of the genus Leuroglossus (Bathylagidae, Pisces). Probl. Ichthyol. (Engl. transl. Vopr. Ikhtiol.) 8:1-10.

BRIGGS, J. C.

1974. Marine zoogeography. McGraw-Hill Book Co., N.Y., 475 p.

BROWNING, R. J

1980. Fisheries of the North Pacific. Revised edition. Alaska Northwest Publ., Anchorage, AK, $423 \mathrm{p}$.

CHAPMAN, W. M., and A. C. DELACY.

1934. New species of Careproctus from Alaska. J. Pan-Pac. Res. Inst. 9:2-5.

COHEN, D. M

1984. Gadiformes: Overview. In Moser, H. G. (chief editor), Ontogeny and systematics of fishes, p. 259-265. Allen Press, Lawrence, KS

COMPAGNO, L. J. V.

1984. FAO species catalogue. Vol. 4. Sharks of the world. Part 1. Hexanchiformes to Lamniformes. FAO Fish. Synop., (125), 249 p.

DARK, T. A., M. O NELSON, J. J. TRAYNOR, and E. P. NUNNALLEE. 1980. The distribution, abundance, and biological characteristics of Pacific whiting, Merluccius productus, in the California-British Columbia region during July-September 1977. Mar. Fish. Rev. 42(3-4);17-33.

DEAN, B.

1906. Chimaeroid fishes and their development. Camegie Inst. Wash. Publ. 32, $194 \mathrm{p}$.
DUNN, J.R.

1983. Development and distribution of the young of northern smoothtongue, Leuroglossus schmidni (Bathylagidae), in the northeast Pacific, with comments on the systematics of the genus Leuroglossus Gilbert. Fish. Bull., U.S. 81:23-40. EKMAN, S.

1953. Zoogeography of the sea. Sidgwick and Jackson Lid., London, $417 \mathrm{p}$. ESCHMEYER, W. N., and E. S. HERALD.

1983. A field guild to Pacific Coast fishes of North America. Houghton Mifflin Company, Boston, 336 p.

FADEEV, N. S

1978. Rasprostranenie i sistematika tikhookeanskikh paltusovidnvkh kambai roda Hippoglossoides (Distribution and systematics of Pacific flatfishes of the genus Hippoglossoides). Izv. Tikhookean. Nauchno-Issled. Inst. Rybn. Khoz. Okeanogr. 102:3-18. [In Russ.] (Transl. by Nat. Mar. Fish. Serv., 1984; copy avail. Northwest and Alaska Fish. Cent., Seattle, WA 98112.)

FEDOROV, V. V.

1966. Novbii vid likoda, Lycodes andriashevi Fedorov, sp. n. (Pisces, Zoarcidae) iz beringova morya (A new species of likod, Lycodes andriashevi Fedorov, sp. n. (Pisces, Zoarcidae) from the Bering Sea). Vopr. Ikhtiol. 6:160-164. [In Russ.] (Trans!. by M. E. Anderson, Va. Inst. Mar. Sci., Gloucester Point, 1979, 7 p.)

1973a. Iktiofauna materikovogo sklona Beringova morya i nekotorye aspekty ee proiskhozhdeniya i formirovaniya (Ichthyofauna of the continental slope of the Bering Sea and some aspects of its origin and formation). Izv. Tikhookean. Nauchno-Issled. Inst. Rybn. Khoz. Okeanogr. 87:3-41. [In Russ.] (Transl. by Transl. Bur., Multilingual Serv. Div., Dep. Secretary of State, Canada; copy avail. Northwest and Alaska Fish. Cent., Seattle, WA 98112.)

1973b. Spisok ryb Beringova morya (A list of Bering Sea fish). Izv. Tikhookean Nauchno-Issled. Inst. Rybn. Khoz. Okeanogr. 87:42-71. [In Russ.] (Transl. by Transl. Bur., Multilingual Serv. Div., Dep. Secretary of State, Canada; copy avail. Northwest and Alaska Fish. Cent., Seattle, WA 98112.)

FITCH, J. E., and R. J. LAVENBERG.

1975. Tidepool and nearshore fishes of California. Univ. Calif. Press, Berkeley, $156 \mathrm{p}$.

FREDIN, R.A., R. L. MAJOR, R. G. BAKKALA, and G. K. TANONAKA

1977. Pacific salmon and the high seas salmon fisheries of Japan. Processed Rep., 324 p. Norhwest and Alaska Fish. Cent., Natl. Mar. Fish. Serv., NOAA, Seattle, WA 98112.

FREY, H. W. (editor).

1971. California's living marine resources and their utilization. Calif. Dep. Fish Game, Sacramento, CA 95814

GARRISON, K. J., and B. S. MILLER.

1982. Review of the early life history of Puget Sound fishes. FRI-UW-8216 729 p. Fish. Res. Inst., Univ. Wash., Seattle, WA 98195

GRANT, W. S.

1986. Biochemical genetic divergence between Atlantic, Clupea harengus, and Pacific, C. pallasi, herring. Copeia 1986(3):714-719.

GUNDERSON, D. R., and T. M. SAMPLE.

1980. Distribution and abundance of rockfish off Washington, Oregon, and California during 1977. Mar. Fish. Rev. 42(3-4):2-16.

HART, J. L.

1973. Pacific fishes of Canada. Buil. Fish. Res. Board Can. 180, 740 p.

HEDGPETH, J. W.

1957a. Classification of marine environments. In Hedgpeth, J. W. (editor), Treatise on marine ecology and paleoecology, p. 17-27. Geol. Soc. Am. Mem. $67(1)$.

1957b. Marine biogeography. In Hedgpeth, J. W. (cditor), Treatise on marine ecology and paleoecology, p. 359-382. Geol. Soc. Am. Mem. 67(1).

HILDEBRAND, S. F

1963. Family Clupeidae. Fishes of the western North Atlantic. Mem. Sears Found. Mar. Res., No. 1, Part 3, p. 257-454.

HITZ, C. R.

1981. Field identification of the northeastern Pacific rockfish (Sebastodes) $=$ Sebasres. 2nd revision of U.S. Fish. Wildl. Serv., Circ. 203, 62 p. (avail. Northwest and Alaska Fish. Cent., Seattle, WA 98112).

HORN, M. H., and L. G. ALLEN.

1978. A distributional analysis of California coastal marine fishes. J. Biogeogr. $5: 23-42$,

1981. A review and synthesis of ichthyofaunal studies in the vicinity of Los Angeles and Long Beach Harbors, Los Angeles County, California. Final Rep. to U.S. Fish Wildl. Serv., Ecological Services, Laguna Niguel, California, 96 p.

HOWE, K. M.

1981. Preliminary checklist of the fishes of the northeastern Pacific Ocean (revised). Unpubl. manuscr., 53 p. School of Fisheries, Univ. Wash., Seattle, WA 98195 . 
HUBBS, C. L.

1946. Wandering of pink salmon and other salmonid fishes into southern California. Calif. Fish Game 32:81-86.

1960. The marine vertebrates of the outer coast. Syst. Zool. 9:134-147.

1974. Review of marine zoogeography. Copeia 1974:1002-1005.

HUGHES, G. W., and R. K. KASHINO.

1984. First records of the agonid fish Sarritor frenatus from British Columbia. Syesis 17:101.

IBARA, R. M

1967. Biology of the midshipman fish, Porichthys notatus Girard. M.A. Thesis, Univ. Calif., Santa Barbara, 69 p.

ICHTHYOLOGICAL SOCLETY OF JAPAN.

1981. Dictionary of Japanese fish names and their foreign equivalents. Sanseido Co., Tokyo, $834 \mathrm{p}$

ILINA, M. B.

1978. K voprosu o polozhenii roda Podothecus Gill v semeistve Agonidae (On the systematic status of the genus Podothecus Gill in the family Agonidae). In Shorsikova, L. V. (redaktor), Morfologiya i sistematika ryb (Morphology and systematics of fishes), p. 13-24. Akad. Nauk SSSR, Zool. Inst. [In Russ.] (Transl. by A. Rathbone, 6 p., avail. Northwest and Alaska Fish. Cent., Seattle, WA 98112 .)

ISHIHARA, H., and R. ISHIYAMA.

1985. Two new North Pacific skates (Rajidae) and a revised key to Bathyraja in the area. Jpn. J. Ichthyol. 32:143-179.

IWAMOTO, T., and D. L. STEIN.

1974. A systematic review of the rattail fishes (Macrouridae: Gadiformes) from Oregon and adjacent waters. Occas. Pap. Calif. Acad, Sci. 111, 79 p.

JONES, B. C., and G. H. GEEN

1976. Taxonomic reevaluation of the spiny dogfish (Squalus acanthias L.) in the northeastern Pacific Ocean. J. Fish. Res. Board Can. 33:2500-2506.

JORDAN, D. S., and B. W. EVERMANN.

1896-1900. The fishes of North and Middle America. Bull. U.S. Nat. Mus. 47, $3313 \mathrm{p}$.

KAIMMER, S. M., J. E. REEVES, D. R. GUNDERSON, G. B. SMITH, and R. A. MacINTOSH.

1976. Baseline information from the 1975 OCSEAP survey of the demersal fauna of the eastern Bering Sea. In Pereyra, W. T., J. R. Reeves, and R. G. Bakkala (editors), Demersal fish and shellfish resources of the eastern Bering Sea in the baseline year 1975, p. 157-367. Processed Rep., Northwest and Alaska Fish. Cent., Natl. Mar. Fish. Serv., NOAA, Seatule, WA 98112

KESSLER, D. W.

1985. Alaska's saltwater fishes and other sea life. Alaska Northwest Publ., Anchorage, AK, $358 \mathrm{p}$.

KINDER, T. H., and J. D. SCHUMACHER.

1981. Hydrographic structure over the continental shelf of the southeastern Bering Sea. In Hood, D. W., and J. A. Calder (editors), The eastern Bering Sea shelf: oceanography and resources, Volume 1, p. 31-52. U.S. Gov. Print. Off., Wash., D.C.

LEA, R. N., and L. F. QUIROLLO.

1986. First record of Hemitripterus bolini, the bigmouth sculpin, from Californian waters. Calif. Fish Game 72(2):117-119.

LEE, D. S., C. R. GILBERT, C. H. HOCUTT, R. E. JENKINS, D. E.

MCALLISTER, and J. R. STAUFFER, Jr.

1980. Atlas of North American freshwater fishes. N.C. State Mus. Nat. Hist., Raleigh, 854 p.

LEIM, A. H., and W. B. SCOTT.

1966. Fishes of the Atlantic coast of Canada. Bull. Fish. Res. Board Can. 155 $485 \mathrm{p}$.

MAJOR, R. L., J. ITO, S. ITO, and H. GODFREY.

1978. Distribution and origin of chinook salmon (Oncorhynchus tshawytscha) in offshore waters of the North Pacific Ocean. Int. North Pac. Fish. Comm. Bull. 38, 54 p.

MAKUSHOK, V. M.

1958. Morfologiya i biologiya pozvonchnykh zhivornykh. (The morphology and classification of the northem blennioid fishes (Stichaeoidae, Blennioidei, Pisces). Tr. Zool. Inst. Akad. Nauk SSSR 25:3-129. [in Russ.] (Transl. by A. R. Gosline, 1959, Ichthyol. Lab., U.S. Fish. Wildl, Serv., U.S. Natl. Mus., Wash., D.C.)

McFARLANE, G. A., and R. J. BEAMISH.

1983. Biology of adult sablefish (Anoplopoma fimbria) in waters off wester Canada. In Melteff, B. R. (editor), Proceedings of the International Sablefish Symposium, p. 59-80. Alaska Sea Grant Rep. 83-8, Univ. Alaska, Fairbanks, AK.
McGOWAN, J. A

1971. Oceanic biogeography of the Pacific. In Funnell, B. M., and W. R. Riedel (editors), The micropaleontology of oceans, p. 3-74. Cambridge Unjv. Press, Cambridge, Engl.

MCKENZIE, R. A.

1953. Arctic or polar cod, Boreogadus saida, in Miramichi Bay, New Brunswick. Copeia 1953:238-239.

MENZIES, R. J., R. Y. GEORGE, and G. T. ROWE

1973. Abyssal environment and ecology of the world oceans. John Wiley and Sons, N.Y., 488 p.

MILLER, D. J., and R. N. LEA.

1972. Guide to the coastal marine fishes of California. Calif. Dep. Fish Game, Fish Bull. 157, 249 p. (Addendum added in 1976.)

MINTEL, R. J., and G. B. SMITH.

1981. A description of the resource survey data-base system of the Northwest and Alaska Fisheries Center, 1981. U.S. Dep. Commer., NOAA Tech. Memo. NMFS F/NWC-18, 111 p. Northwest and Alaska Fish. Cent., Seattle, WA 98112.

MITCHELL, C. T., and J. R. HUNTER.

1970. Fishes associated with drifting kelp, Macrocystis pyrifera, off the coast of southern California and northern Baja California. Calif. Fish Game 56:288-297.

MORROW, J. E

1980. The freshwater fishes of Alaska. Alaska Northwest Publ. Co., Anchorage, AK, 248 p.

MOSER, H. G., E. H. AHLSTROM, and E. M. SANDKNOP.

1977. Guide to the identification of scorpionfish larvae (Family Scorpaenidae) in the Eastern Pacific with comparative notes on species of Sebastes and Helicolenus from other oceans. U.S. Dep. Commer., NOAA Tech. Rep. NMFS Circ. 402, 71 p.

MOYLE, P. B.

1976. Inland fishes of California. Univ. Calif. Press, Berkeley, $405 p$

MUUS, B. J

1974. Collins guide to the sea fishes of Britain and northwestern Europe. Collins, London, $244 \mathrm{p}$

NELSON, D. W

1984. Systematics and distribution of cottid fishes of the genera Rastrinus and Icelus. Occas. Pap. Calif. Acad. Sci. 138, 58 p.

NELSON, J, S

1984. Fishes of the world, 2nd ed. John Wiley and Sons, N.Y., 523 p

NEELOV, A. V.

1979. Seismosensory systems and the classification of kerchaki fishes (Cottidae: Myoxocephalinae, Artediellinae). "Nauka," Leningrad Otdel, 208 p.

NIE, N. H., C. H. HULL, J. G. JENKINS, K. STEINBRENNER, and D. H. BRENT.

1975. SPSS, statistical package for the social sciences. McGraw-Hill Book Co., N.Y. 675 p.

OKADA, S., and K. KOBAYASHI.

1968. Hokuyo-gyorui-zusetsu (IIlustrations and descriptions of the fishes of the northern seas). Sanseido, Tokyo, 179 p. [In Japanese].

PARKS, N. B., and S. E. HUGHES

1981. Changes in relative abundance and size composition of sablefish in coastal waters of Washington and Oregon, 1979-80. U.S. Dep. Commer., NOAA Tech. Memo. NMFS F/NWC-8, 25 p. Northwest and Alaska Fish. Cent., Seattle, WA 98112 .

PEDEN, A. E

1978. A systematic revision of the hemilepidotine fishes (Cortidae). Syesis $11: 11-49$.

1981. Recognition of Leuroglossus schmidri and L. stilbius (Bathylagidae, Pisces) as distinct species in the North Pacific Ocean. Can. J. Zoot. 59:2396-2398.

PEDEN, A. E., and D. E. WILSON.

1976. Distribution of intertidal and subtidal fishes of northern British Columbia and southeastern Alaska. Syesis 9:221-248.

QUAST, J. C.

1968. Fish fauna of the rocky inshore zone. In North, W. J., and C. L. Hubbs (editors), Utilization of kelp-bed resources in southern California, p. 35-55. Calif. Dep. Fish Game, Fish Bull. 139.

QUAST, J. C., and E. L. HALL.

1972. List of fishes of Alaska and adjacent waters with a guide to some of their literanure. U.S. Dep. Commer., NOAA Tech., Rep. NMFS SSRF-658, 47 p.

RANCK, C. L., F. M. UTTER, G. B MILNER, and G. B SMITH.

1986. Genetic confirmation of specific distinction of arrowtooth flounder, Atheresthes stomias, and Kamchatka flounder, A. evermanni. Fish. Bull., U.S. $84: 222-226$ 
RICHARDS, L. J., and S. J. WESTRHEIM.

In press. The southern range extension of dusky rockfish, Sebastes ciliatus, in British Columbia. Can. Field-Naturalist.

ROBINS, C. R. (chairman).

1980. A list of common and scientific names of fishes from the United States and Canada. Am. Fish. Soc., Spec. Publ. 12, 174 p.

ROSENBLATT, R. H., and L.-C. CHEN.

1972. The identity of Sebastes babcocki and Sebastes rubrivinctus. Calif. Fish Game 58:32-36.

RUTENBERG, E. P.

1962. Survey of the fishes of family Hexagrammidae. In Rass, T. S. (editor), Terpugovye ryby i vozmozhnosti ikh mezhokeanskoi transplantatsi (Greenlings-taxonomy, biology, interoceanic transplantation). $\Upsilon_{r}$. Inst. Okeanol., Akad. Nauk SSSR 59:1-103. [In Russ.] (Transl. by Israel Program Sci. Transl., 1970, 207 p., avail. U.S, Dep. Commer., Natl. Tech. Inf. Serv., Springfield, VA, as TT 69-55097.)

SAKAMOTO, K

1984. Interrelationships of the family Pleuronectidae (Pisces: Pleuronectiformes). Mem. Fac. Fish., Hokkaido Univ, 31:95-215.

SASAKI, T.

1985. Studies on the sablefish resources in the North Pacific Ocean. Far Seas Fish. Res. Lab., Shimizu, Jpn., Bull. 22, 108 p.

SHMIDT, P. Y.

1950. Ryby Okhotskogo morya (Fishes of the Sea of Okhotsk). Akad. Nauk SSSR, Tr. Tikhookean. Kom. 6, 370 p. Izd. Akad. Nauk SSSR, MoscowLeningrad. [In Russ.] (Trans]. by Israel Program Sci. Transl., 1965, 392 p., avail. U.S. Dep. Commer., Natl. Tech. Inf. Serv., Springfield, VA, as TT 65-50022.)

SHUNTOV, V. P.

1965. Raspredelenie chernogo i strelozubykh palusov $v$ servernoi chast Thikhogo okeana (Distribution of the Greenland halibut and arrow-toothed halibuts in the North Pacific). Tr. Vses. Nauchno-Issled. Inst. Morsk. Rybn. Khoz. Okeanogr. 58 (Izv. Tikhookean. Nauchno-Issled. Inst. Morsk. Rybn. Khoz. Okeanogr. 53):155-163. [In Russ.[ (Transl. by Israel Program Sci. Transl., 1968, in Moiseev, P. A. (editor), Soviet fisheries investigations in the northeast Pacific, part 4, p. 147-156, avail. U.S. Dep. Commer, Natl. Tech. Inf. Serv, Springfield, VA, as TT 67-51206.)

SIMENSTAD, C. A.

1983. The ecology of estuarine channels of the Pacific Northwest coast: A community profile. U.S. Fish. Wildl. Serv., FSW/OBS-83/05, 181 p.

SIMENSTAD, C. A., J. S. ISAKSON, and R. E. NAKATANI.

1977. Marine fish communities. In Merritt, M. L., and R. G. Fuller (editors), The environment of Amchitka Island, Alaska, p. 451-492. Technical Information Center, Energy Research and Development Administration, Springfield, VA.

SMALL, G. J.

1981. A review of the bathyal fish genus Antimora (Moridae: Gadiformes). Proc. Calif. Acad. Sci, 42(13):341-348.

SMITH, G. B., and R. G. BAKKALA.

1982. Demersal fish resources of the eastem Bering Sea: spring 1976. U.S. Dep. Commer., NOAA Tech. Rep. NMFS SSRF-754, 129 p.

SVETOVIDOV, A. N.

1948. Treskoobraznye (Gadiformes). Akad. Nauk SSSR, Zool. Inst., Fauna SSSR, Ryby, 9(4), N.S. 34, 221 p. [In Russ.] (Transl. by Israel Program Sci. Transl., 1962, 304 p., avail. U.S. Dep. Commer., Natl. Tech. Inf. Serv., Springfield, VA, as OTS 63-11071.)

TOWNSEND, C. H., and J. T. NICHOLS.

1925. Deepsea fishes of the 'Albatross' Lower California Expedition. Bull. Am. Mus. Nat. Hist. 52:1-19.

TSUYUKI, H., and S. J. WESTRHEIM

1970. Analyses of the Sebastes aleutianus-S. melanostomus complex, and description of a new scorpaenid species, Sebastes caenaematicus, in the northeast Pacific Ocean. J. Fish. Res. Board Can. 27:2233-2254.

UENO, T.

1970. Cyclopteridae (Pisces). Fauna Japonica. Academic Press, Tokyo, 233 p. WATHNE, F.

1977. Performance of trawls used in resource assessment. Mar. Fish. Rev. 39(6): 16-23.

WEBBER, R. A., and T. M. SAMPLE.

1976. Arrowtooth flounder (family Pleuronectidae). In Pereyra, W. T., J. T. Reeves, and R. G. Bakkala (editors), Demersal fish and shellfish resources of the eastern Bering Sea in the baseline year 1975, p. 523-529. Processed Rep., Northwest and Alaska Fish. Cent., Natl. Mar. Fish. Serv., NOAA, Seattle, WA 98112 .
WHEELER, A.

1969. The fishes of the British Isles and north-west Europe. Mich. State Univ. Press, East Lansing, 613 p.

1978. Key to the fishes of northern Europe. Frederick Warne, London, $380 \mathrm{p}$. WILIMOVSKY, N.J.

1958. Provisional keys to the fishes of Alaska. Fish. Res. Lab. U.S. Fish Wild] Serv., Juneau, AK, 113 p.

1964. Inshore fish fauna of the Aleutian archipelago. In Dahlgren, G. (editor), Proceedings of the Fourteenth Alaskan Science Conference, Anchorage, Alaska, p. 172-190. Am. Assoc. Adv. Sci., Alaska Div.

WOLOTIRA, R. J., Jr., T. M. SAMPLE, and M. MORIN, Jr.

1977. Demersal fish and shellfish resources of Norton Sound, the southeastern Chukchi Sea, and adjacent waters in the baseline year 1976. Processed Rep., 292 p. Northwest and Alaska Fish. Cent., Natl. Mar. Fish. Serv., NOAA, Seattle. WA 98112 .

YABE, $M$.

1985. Comparative osteology and myology of the superfamily Cottoidea (Pisces: Scorpaeniformes), and its phylogenetic classification. Mem. Fac. Fish., Hokkaido Univ. 32, 130 p.

YABE, M., S. MARUYAMA, and K. AMAOKA.

1983. First records of five cortid fishes and a psychrolutid fish from Japan. Jpn J. Ichehyol. 29:456-464. 


\section{SYSTEMATIC INDEX}

Agonus acipenserinus (see Podothecus acipenserinus), 77 Albatrossia pectoralis, 8, 25, 134, 135, 137, 141

Alligatorfish, Aleutian, 8, 73

Alosa sapidissima, 8, 17, 134, 136, 138, 141

Ammodytes hexapterus, 9, 114, 135, 136, 139, 143

Anoplopoma fimbria, 8, 9, 61, 134, 137, 140, 142

Antimora microlepis, 8, 33, 134, 138, 141, 142

Aprodon cortezianus (see Lycodes cortezianus), 103

Aptocyclus ventricosus, 8, 65, 135, 137, 138, 142

Aspidophoroides bartoni, 8, 73, 134, 136, 139, 142

Atheresthes evermanni, 9, 116, 117, 135, 136, 140, 143

stomias, 7, 9, 116, 117, 135, 137, 140, 143

Bathyagonus nigripinnis, 8, 74, 134, 137, 140, 142

Bathylagus schmidti (see Leuroglossus schmidti), 19 stilbius (see Leuroglossus stilbius), 19

Bathymaster signatus, 8, 98, 134, 136, 140, 143

Bathyraja aleutica, 13, 14, 15

interrupta, 8, 13, 134, 137, 140, 141

kincaidii (see Bathyraja interrupta), 13

parmifera, 9, 13, 16

Bocaccio, 8, 51, 135

Boreogadus saida, 8, 28, 134, 136, 138, 142

Bothrocara brunneum, 8, 100, 134, 137, 141, 143

Capelin, 8, 9, 20

Careproctus colletti, 8, 9, 66

cypselurus, $8,9,66$

furcellus, 8, 9, 66

melanurus, 8, 9, 66

melanurus complex, 8, 66

osborni, 8, 9, 67

phasma, 8, 9, 67

rastrinus, 8, 9, 67

rastrinus complex, 8,67

scottae, $8,9,67$

Chauliodus macouni, 8, 24, 134, 138, 141

Chilipepper, 8, 47, 135

Citharichthys sordidus, 9, 115, 135, 138, 139, 143

Clupea harengus, 18

harengus pallasi (see Clupea pallasii), 18

pallasii, 8, 9, 18, 134, 136, 138, 141

Cod, Arctic, 8, 28

Pacific, 7, 8, 9, 30

Saffron, 8, 29, 31

Coryphaenoides cinereus, 8, 26, 134, 135, 137, 141

pectoralis (see Albatrossia pectoralis), 25

Dab, Longhead, 9, 129

Dasycottus setiger, 8, 9, 70, 134, 136, 140, 142

Dogfish, Spiny, 8, 11

Eelblenny, Slender, 8, 109

Eelpout, Bigfin, 8, 103

Black, 8, 104

Ebony, 8, 102

Marbled, 8, 106

Polar, 8, 107

Shortfin, 8, 9, 101

Twoline, 8,100

Wattled, 8, 9, 105

Eleginus gracilis, 8, 29, 31, 134, 136, 139, 142

Enophrys diceraus, 8, 80, 134, 136, 139, 142

Eopsetta exilis, 9, 117, 118, 135, 137, 140, 143
Eopsetta jordani, 9, 119, 135, 137, 140, 143

Errex zachirus, 9, 120, 135, 137, 140, 143

Eulachon, 8, 9, 22

Eumicrotremus orbis, 8, 68, 134, 136, 139, 142

Flatnose, Pacific, 8, 33

Flounder, Arrowtooth, 7, 9, 116, 117, 135

Bering, 9, 121, 122

Kamchatka, 9, 116, 117

Red, 121

Starry, 9, 125

Gadus macrocephalus, 8, 9, 30, 134, 137, 139, 142

Glyptocephalus zachirus (see Errex zachirus), 120

Greenling, Whitespotted, 8, 62

Grenadier, Giant, 8, 25, 135

Popeye, 8, 26, 135

Gymnocanthus galeatus, 8, 81, 134, 137, 139, 142

pistilliger, 8, 82, 134, 136, 139, 142

tricuspis, 8, 83, 134, 136, 139, 142

Hake, Pacific, 8, 27

Halibut, Greenland, 9, 133

Pacific, 7, 9, 123

Hemilepidotus hemilepidotus, 8, 84, 134, 137, 140, 142 jordani, 8, 9, 85, 134, 137, 139, 143

papilio, 8, 84, 86, 134, 136, 139, 143

Hemitripterus bolini, 8, 9, 79, 134, 137, 140, 142

Herring, Atlantic, 18

Pacific, 8, 9, 18

Hexagrammos stelleri, 8, 62, 134, 136, 139, 142

Hippoglossoides dubius, 121

elassodon, 7, 9, 121, 122, 135, 137, 140, 143

robustus, 9, 121, 122, 135, 136, 139, 143

Hippoglossus stenolepis, 7, 9, 123, 136, 139, 143

Hydrolagus colliei, 8, 10, 134, 138, 140, 141

Icelinus filamentosus, 8, 87, 134, 137, 140, 143

Icelus canaliculatus, 8, 88, 134, 136, 141, 143

spiniger, 8, 89, 134, 136, 139, 143

Isopsetta isolepis (see Pleuronectes isolepis), 128

Lance, Pacific Sand, 9, 114

Lepidopsetta bilineata (see Pleuronectes bilineatus), 127

Leptoclinus maculatus (see Lumpenus maculatus), 110

Leuroglossus schmidti, 8, 19, 135, 137, 138, 141 stilbius, 19

Limanda aspera (see Pleuronectes asper), 126 proboscidea (see Pleuronectes proboscideus), 129 sakhalinensis (see Pleuronectes sakhalinensis), 128

Lingcod, 8, 63

Liparis dennyi, 69 gibbus, 8, 69, 135, 136, 139, 142

Lord, Red Irish, 8, 84

Yellow Irish, 8, 9, 85

Lumpenella longirostris, 8, 108, 134, 136, 139, 143

Lumpenus fabricii, 8, 109, 134, 136, 139, 143

maculatus, 8, 110,135, 136, 139, 143

sagitta, 8, 111, 135, 137, 139, 143

Lumpsucker, Pacific Spiny, 8, 68

Smooth, 8, 65

Lycodes andriashevi, 102

brevipes, 8, 9, 101, 134, 137, 139, 143

concolor, 9, 102, 134, 136, 141, 143

cortezianus, 8, 103, 134, 137, 140, 143

diapterus, 8, 104, 134, 137, 140, 143

palearis, $8,9,105,134,136,139,143$ 
Lycodes raridens, 8, 106, 134, 136, 139, 143

soldatovi, 9,102

tumeri, 8, 107, 134, 136, 139, 143

Lyopsetta exilis (see Eopsetta exilis), 118

Mackerel, Atka, 8, 64

Malacocottus kincaidi, 8, 71, 72, 134, 137, 140, 142

zonurus, 8, 71, 72, 134, 136, 140, 142

Mallotus villosus, 8, 9, 20, 134, 136, 138, 141

Melletes papilio (see Hemilepidotus papilio)

Merluccius productus, 8, 27, 135, 138, 141

Microgadus proximus, 8, 31, 134, 137, 139, 142

Microstomus pacificus, 9, 124, 135, 138, 140, 143

Midshipman, Plainfin, 8, 34

Myoxocephalus groenlandicus (see Myoxocephalus verrucosus), 92 jaok, 8, 90, 91, 134, 136, 139, 142

polyacanthocephalus, 8, 9, 91, 134, 137, 139, 143

scorpius, 92

scorpius groenlandicus (see Myoxocephalus verrucosus), 92 verrucosus, $8,91,92,135,136,139,143$

Occella dodecaedron, 8, 75, 76, 134, 136, 139, 142

verrucosa, 8, 76, 134, 137, 139, 142

Oncorhynchus tshawytscha, 8, 23, 134, 136, 138, 141

Ophiodon elongatus, 8, 63, 134, 137, 139, 142

Osmerus eperlanus, 21

mordax , 8, 21, 134, 136, 138, 141

Parophrys vetulus (see Pleuronectes vetulus), 131

Perch, Pacific Ocean, 8, 9, 36

Plaice, Alaska, 9, 130

Platichthys stellatus, 9, 125, 135, 136, 139, 143

Pleurogrammus monopterygius, 8, 64, 134, 137, 139, 142

Pleuronectes asper, 9, 126, 135, 136, 139, 143

bilineatus, $7,9,127,135,136,139,143$

isolepis, 9, 128, 132, 135, 137, 139, 143

proboscideus, 9, 129, 135, 136, 139, 143

quadrituberculatus, $9,130,135,136,139,143$

sakhalinensis, 128,132

vetulus, 9, 131, 135, 138,139, 143

Poacher, Bering, $8,75,76$

Blackfin, 8, 74

Sawback, 8, 78

Sturgeon, 8, 9, 77

Warty, 8, 76

Podothecus acipenserinus, 8, 9, 77, 134, 136, 139, 142

Pollock, Walleye, 7, 8, 9, 32

Porichthys notatus, 8, 34, 135, 138, 139, 142

Prickleback, Longsnout, 8, 108

Snake, 8, 111

Prowfish, 9, 112

Psettichthys melanostictus, 9, 132, 135, 137, 139, 143

Raja binoculata, 8, 14, 134, 135, 137, 139, 141

interrupta (see Bathyraja interrupta), 13

kincaidi (see Bathyraja interrupta), 13

rhina, $8,15,134,135,137,139,141$

stellulata, 9, 16

stellulata complex, 8, 16

Ratfish, Spotted, 8, 10

Ray, Pacific Electric, 8, 12

Reinhardtius hippoglossoides, 9, 133, 135, 136, 140, 143

Rockfish, Aurora, 8, 37

Blackgill, 8, 50

Canary, 8, 52, 135

Darkblotched, 8, 42, 135
Rockfish, Dusky, 8, 41

Flag, 8, 56, 144

Greenstriped, 8, 44, 135

Harlequin, 8, 58

Northern, 8, 53

Redbanded, 8, 38, 56

Redstripe, 8, 54, 135

Rosethorn, 8, 48, 135

Rougheye, 8, 9, 35

Sharpchin, 8, 59, 135

Shortbelly, 8, 49, 135

Shortraker, 8, 35, 39, 50

Silvergray, 8, 40, 135

Splitnose, 8, 43

Stripetail, 8, 57

Widow, 8, 45, 135

Yelloweye, 8, 55, 135

Yellowtail, 8, 46, 135

Ronquil, Northern, 8, 99

Ronquilus jordani, 8, 99, 134, 137, 139, 143

Sablefish, 8, 9, 61

Salmon, Chinook, 8, 23

Sanddab, Pacific, 9, 115

Sandfish, Pacific, 9, 113

Sarritor frenatus, 8, 78, 134, 136, 140, 142

Sculpin, Antlered, 8, 80

Armorhead, 8, 81

Arctic Staghorn, 8, 83

Bigmouth, 8, 9, 79

Blackfin, 8, 71, 72

Butterfly, 8, 84, 86

Darkfin, 8, 71, 72

Great, 8, 9, 91

Plain, 8, 90, 91

Porehead, 8,88

Ribbed, 8, 95

Roughspine, 8, 94

Scissortail, 8, 93

Shorthorn, 92

Spectacled, 8, 96

Spinyhead, 8, 9, 70

Thorny, 8, 89

Threaded, 8,82

Threadfin, 8,87

Warty, 8, 91, 92

Seaperch, Pink, 8, 97, 144

Searcher, 8, 98

Sebastes aleutianus, 8, 9, 35, 134, 137, 140, 142

alutus, 8, 9, 36, 134, 137, 140, 142

aurora, 8, 37, 134, 138, 140, 142

babcocki, 8, 38, 56, 134, 137, 140, 142

borealis, 8, 35, 39, 50, 134, 137, 140, 142

brevispinis, 8, 40,134, 135, 137, 140, 142

ciliatus, $8,41,134,137,140,142$

crameri, $8,42,134,135,137,140,142$

diploproa, $8,43,135,138,140,142$

elongatus, $8,44,134,135,137,140,142$

entomelas, 8, 45, 134, 135, 137, 140, 142

flavidus, 8, 46, 134, 135, 137, 140, 142

goodei, 8, 47, 134, 135, 138, 140, 142

helvomaculatus, $8,48,134,135,137,142$

jordani, $8,49,134,135,138,140,142$ 
Sebastes melanostomus, 8, 50, 134, 138, 141, 142 paucispinis, 8, 51, 134, 135, 137, 140, 142 pinniger, 8, 52, 134, 135, 137, 140, 142 polyspinis, 8, 53, 134, 137, 140, 142 proriger, 8, 54, 134, 135, 137, 140, 142 ruberrimus, $8,55,134,135,137,140,142$ rubrivinctus, 8, 56, 134, 138, 140,142, 144 saxicola $, 8,57,134,138,139,142$ variegatus, $8,58,134,137,139,142$ zacentrus, 8, 59, 134, 135, 137, 140, 142

Sebastolobus alascanus, 8, 9, 60, 134, 137, 140, 142

Shad, American, 8, 17

Shanny, Daubed, 8, 110

Skate, Alaska, 9, 13, 16

Aleutian, 13, 14, 15

Bering, 8, 13

Big, 8, 14, 135

Longnose, 8, 15, 135

Sandpaper, 13

"Starry," 8, 16

Starry, 9, 16

Smelt, European, 21

Rainbow, 8, 21

Smoothtongue, California, 19

Northern, 8, 19

Snailfish, Alaska, 8, 9, 66

Blackfinned, 8, 9, 66

"Blacktail," 8, 66

Blacktail, 8, 9, 66

Dusky, 8, 69

Forktail, 8, 9, 66

Marbled, 69

Monster, 8, 9, 67

Peachskin, 8, 9, 67

“Pink," 8, 67

Pink, 8, 9, 67

Salmon, 8, 9, 67

Sole, Butter, 9, 128, 132

Dover, 9, 124

English, 9, 131

Flathead, 7, 9, 121, 122

Petrale, 9, 119, 135

Rex, 9, 120, 135

Rock, 7, 9, 127

Sakhalin, 128, 132

Sand, 9, 132

Slender, 9, 117, 118, 135

Yellowfin, 9, 126

Squalus acanthias, 8, 11, 134, 138, 139, 141
Thaleichthys pacificus, 8, 9, 22, 134, 137, 138, 141

Theragra chalcogramma, 7, 8, 9, 32, 134, 136, 138, 142 Thornyhead, Shortspine, 8, 9, 60

Tomcod, Pacific, 8, 31

Torpedo californica, 8, 12, 134, 138, 140, 141

Trichodon trichodon, 9, 113, 135, 137, 139, 143

Triglops forficata, 8, 93, 134, 137, 139, 143

macellus, 8, 94, 134, 137, 139, 143

pingeli, 8, 95, 134, 136, 139, 143

scepticus, 8, 96, 134, 136, 140, 143

Turbot, Greenland (see Halibut, Greenland)

Whiting, Pacific (see Hake, Pacific)

Viperfish, Pacific, 8, 24

Zalembius rosaceus, 8, 97, 134, 138, 140, 143, 144

Zaprora silenus, 9, 112, 135, 137, 139, 143 
